Supplemental Project To Assess the Transparency of Reporting Requirements: Omega-3 Fatty Acids and Cardiovascular Disease

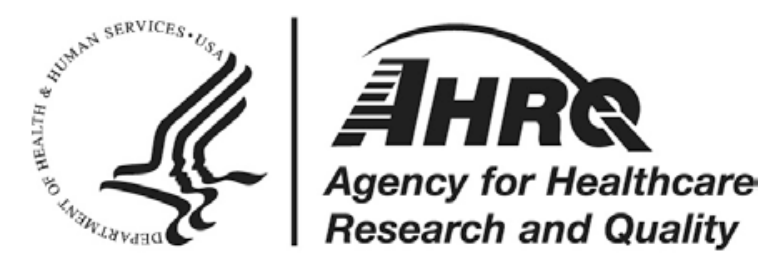




\section{Supplemental Project To Assess the Transparency of Reporting Requirements: Omega-3 Fatty Acids and Cardiovascular Disease}

Prepared for:

Agency for Healthcare Research and Quality

U.S. Department of Health and Human Services

5600 Fishers Lane

Rockville, MD 20857

www.ahrq.gov

Contract No. 290-2015-00002-I; 290-32004-T

Prepared by:

Brown University

Providence, RI

Investigators:

Stacey Springs, Ph.D.

Gaelen P. Adam, MLIS

Valerie Langberg, Sc.M.

Chris Halliday, Sc.M.

Thomas A Trikalinos, M.D.

AHRQ Publication 17-EHC019-EF

June 2017 
This report is based on research conducted by the Brown University Evidence-based Practice Center (EPC) under contract to the Agency for Healthcare Research and Quality (AHRQ), Rockville, MD (Contract No. 290-2015-00002-I; 290-32004-T). The findings and conclusions in this document are those of the author(s), who are responsible for its content, and do not necessarily represent the views of AHRQ. No statement in this report should be construed as an official position of AHRQ or of the U.S. Department of Health and Human Services.

\section{None of the investigators have any affiliations or financial involvement that conflicts with the material presented in this report.}

The information in this report is intended to help health care decisionmakers—patients and clinicians, health system leaders, and policymakers, among others-make well-informed decisions and thereby improve the quality of health care services. This report is not intended to be a substitute for the application of clinical judgment. Anyone who makes decisions concerning the provision of clinical care should consider this report in the same way as any medical reference and in conjunction with all other pertinent information, i.e., in the context of available resources and circumstances presented by individual patients.

This report is made available to the public under the terms of a licensing agreement between the author and the Agency for Healthcare Research and Quality. This report may be used and reprinted without permission except those copyrighted materials that are clearly noted in the report. Further reproduction of those copyrighted materials is prohibited without the express permission of copyright holders.

AHRQ or U.S. Department of Health and Human Services endorsement of any derivative products that may be developed from this report, such as clinical practice guidelines, other quality enhancement tools, or reimbursement or coverage policies may not be stated or implied.

Persons using assistive technology may not be able to fully access information in this report. For assistance, contact epc@ahrq.hhs.gov.

Suggested citation: Springs S, Adam GP, Langberg V, Halliday C, Trikalinos TA. Supplemental Project to Assess the Transparency of Reporting Requirements: Omega-3 Fatty Acids and Cardiovascular Disease. Methods Research Report. (Prepared by the Brown University Evidence-based Practice Center under Contract No. 290-2015-00002-I; 290-32004T). AHRQ Publication No. 17-EHC019-EF. Rockville, MD: Agency for Healthcare Research and Quality. June 2017. www.effectivehealthcare.ahrq.gov/reports/final.cfm. DOI: https:// doi.org/10.23970/AHRQEPCMETH3. 


\section{Preface}

The Agency for Healthcare Research and Quality (AHRQ), through its Evidence-based Practice Centers (EPCs), sponsors the development of evidence reports and technology assessments to assist public- and private-sector organizations in their efforts to improve the quality of health care in the United States. The reports and assessments provide organizations with comprehensive, science-based information on common, costly medical conditions and new health care technologies and strategies. The EPCs systematically review the relevant scientific literature on topics assigned to them by AHRQ and conduct additional analyses when appropriate prior to developing their reports and assessments.

To improve the scientific rigor of these evidence reports, AHRQ supports empiric research by the EPCs to help understand or improve complex methodologic issues in systematic reviews. These methods research projects are intended to contribute to the research base in and be used to improve the science of systematic reviews. They are not intended to be guidance to the EPC program, although may be considered by EPCs along with other scientific research when determining EPC program methods guidance.

AHRQ expects that the EPC evidence reports and technology assessments will inform individual health plans, providers, and purchasers as well as the health care system as a whole by providing important information to help improve health care quality. The reports undergo peer review prior to their release as a final report.

We welcome comments on this Methods Research Project. They may be sent by mail to the Task Order Officer named below at: Agency for Healthcare Research and Quality, 5600 Fishers Lane, Rockville, MD 20857, or by e-mail to epc@ahrq.hhs.gov.

Gopal Khanna, M.B.A.

Director

Agency for Healthcare Research and Quality

Stephanie Chang, M.D., M.P.H. Director, Evidence-based Practice Center Program Center for Evidence and Practice Improvement Agency for Healthcare Research and Quality
Arlene S. Bierman, M.D., M.S.

Director

Center for Evidence and Practice

Improvement

Agency for Healthcare Research and Quality

Elise Berliner

TOO, Evidence-based Practice Center

Program

Center for Evidence and Practice Improvement

Agency for Healthcare Research and Quality 


\section{Supplemental Project to Assess the Transparency of Reporting Requirements: Omega-3 Fatty Acids and Cardiovascular Disease}

\section{Structured Abstract}

Introduction. Clinical trial registries that include prospective registration of study protocols and summarized results can inform the prevalence and impact of information bias. This methods report examines the feasibility and added utility of comprehensive searches of registries to supplement the evidence identified in an ongoing systematic review update on omega-3 fatty acids (n-3 FA) and CVD outcomes.

Data sources. We conducted searches in ClinicalTrials.gov and the International Clinical Trials Registry Platform, using terms that matched those used in the original review database searches.

Results. The original report included 98 studies (61 randomized controlled trials in 82 articles, and 37 longitudinal observational studies in 65 articles). We compared our registry search yield with our original report to identify studies: (1) registry record present, included in original review (26 studies, 4 with eligible results); we found that, in general, the agreement between the registry record and the published paper was good when the information was given in both. (2) Registry record present, not included in original review (43 studies); of these 23 were completed, 10 were ongoing, and 13 had unknown status. A single record yielded a new publication emanating from a study included in the original report. (3) No registry record, included in original review (72 studies); we posit that this is, in part, because many of the studies in the report predate the requirement to register trials.

Conclusions. While we found that for this project, searching registry data added little to the evidence, one way in which conducting a registry search is of value to a systematic review project is in identifying ongoing research and gaps in knowledge. Several of the studies not found in the original review but identified through registry searches were unfinished or in progress at the time of the search. These studies should be taken in to account when evaluating the state of the literature and calling for future research. 


\section{Contents}

Background and Objectives ................................................................................................................ 1

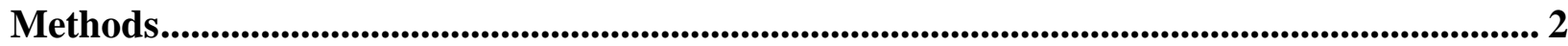

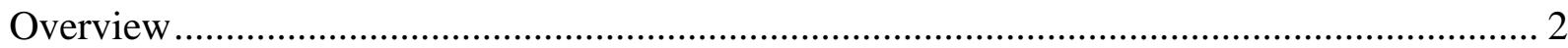

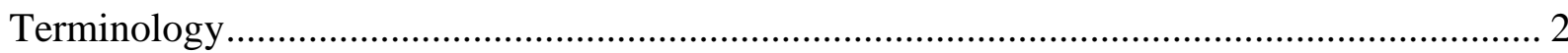

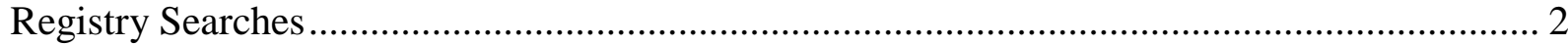

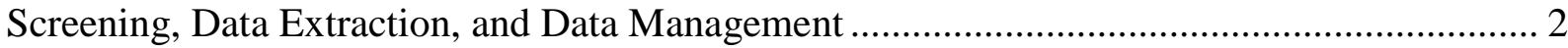

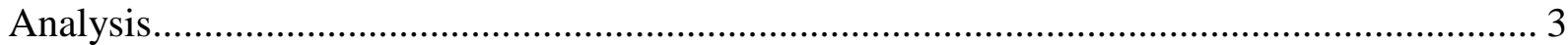

Risk of bias for the evidence base and Strength of Evidence .......................................... 3

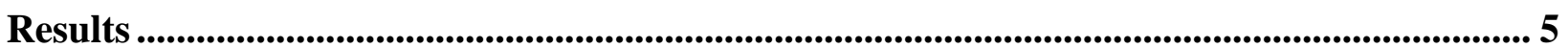

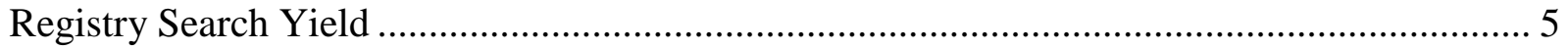

Comparison of Registry Searches with Original Review …................................................. 6

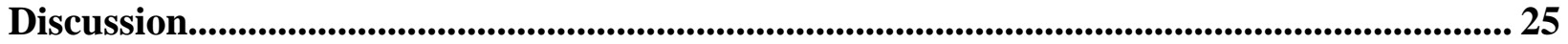

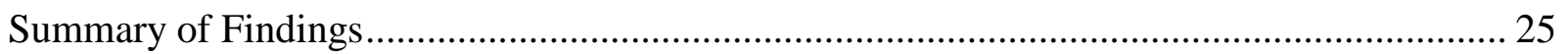

Studies Identified via Registry Searches and Found in Original Review .......................... 25

Relevant Studies Identified via Registry Searches and Not Found in Original Review....... 25

Studies Included in the Original Review, with No Registry Record ................................. 25

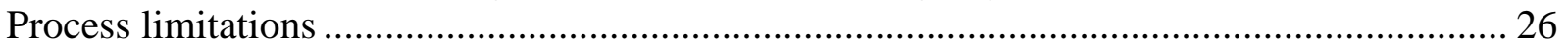

Challenges to Incorporating Clinical Trial Registry Records into the Systematic Review

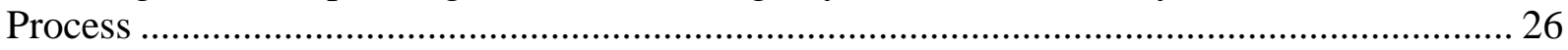

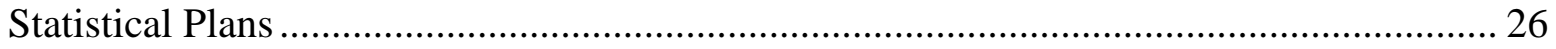

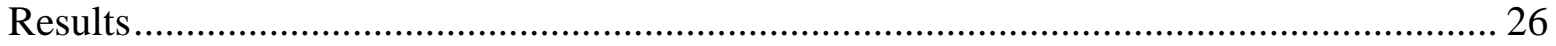

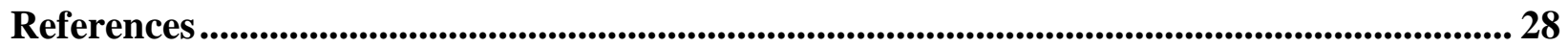

Tables

Table 1. Overall description of studies in both the report and registry from the registry records.. 6

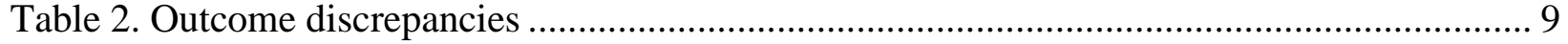

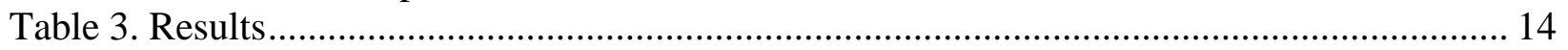

Table 4. Overall description of studies in the registry but not the report ................................. 17

Figures

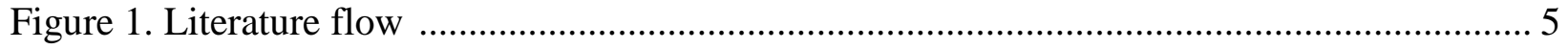

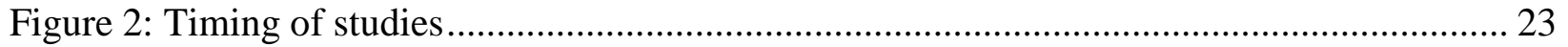

\section{Appendixes}

Appendix A. Search Strategies

Appendix B. Inclusion criteria: Effects of Omega-3 Fatty Acids on Cardiovascular Disease

Appendix C. Risk of Bias Criteria from the Original Report

Appendix D. Excluded Studies

Appendix E. Studies in Both the Report and Registry 


\section{Background and Objectives}

Information biases, including publication bias, time-lag bias, selective outcome reporting bias, selective analysis bias, and fraud are major threats to the validity of systematic reviews. Systematic reviewers have pursued two methods approaches for dealing with information bias, namely, detecting (and possibly correcting results for) information bias based only on the identified studies (e.g., using funnel-plot based methods ${ }^{1-4}$ or various selection models ${ }^{5-7}$ ), and examining trial registries, surveying researchers, and perusing the grey literature to identify unpublished study results or ongoing studies. Arguably the best way to obtain empirical data on the prevalence and impact of information bias and perhaps to mitigate its impact is through clinical trial registries that include prospective registration of study protocols, as well as summarized results (e.g., the National Library of Medicine ClinicalTrials.gov registry and registry networks, such as International Clinical Trials Registry Platform [ICTRP]). Advocates of clinical trial registration emphasize the role of registry platforms to disseminate aggregated results to researchers, clinicians, and study participants. Registries enhance transparency by providing an inventory of studies that are in progress or have been completed. ${ }^{8-10}$

Empirical analyses of prospective registration of studies (defined here as registration of investigational studies prior to enrollment of the first patient or, for observational studies, prior to initial analyses) can inform on the time between study completion and publication, the number of unpublished studies, the fidelity of studies to registered protocols, and the congruence of study results between registry records and publications. ${ }^{11-14}$

This methods report assesses the value of searching ClinicalTrials.gov and ICTRP registry records in a systematic review of dietary supplements. Obtaining empirical data on studies of dietary supplements (e.g., fish oil) and interventions (e.g., increase of fish servings per week) in the context of a major clinical condition (e.g., cardiovascular disease [CVD]) adds to existing knowledge because the mechanisms through which information bias operates in this case may differ from studies of medications. The existing empirical research on information bias pertains almost exclusively to industry-sponsored drug, device, and biologic trials, ${ }^{15-17}$ despite the fact that 42 percent (88023) of all studies registered in ClinicalTrials.gov are indexed as “observational” or "behavioral/other intervention studies". ${ }^{18}$ Omega-3 fatty acids derive from both dietary supplements and consumption through a variety of plants and animal sources and these studies typically fall under these observational and other intervention studies. The inclusion of registry searches in our omega-3 review, will add to our understanding of the role of registry searching in non-industry, non-drug studies.

\section{Objectives}

We examine the feasibility and added utility - in terms of impact on risk of bias and strength of evidence assessments - of comprehensive searches of the ClinicalTrials.gov and ICTRP registries to supplement the evidence identified in an ongoing systematic review update on omega-3 fatty acids (n-3 FA) and CVD outcomes conducted by the Brown Evidence-based Practice Center (EPC). ${ }^{19-21}$ 


\section{Methods}

\section{Overview}

The Brown EPC conducted a review of the relationship between n-3 FA intake and CVD outcomes, following Institute of Medicine standards and Agency for Healthcare Research and Quality (AHRQ) guidance. This review (hereafter, “original review”) did not include registry searches as part of the strategy to identify ongoing studies.

We searched ClinicalTrials.gov and ICTRP up to the last search date of the original review (6/8/2015) to identify additional studies not identified in the original review, or additional information on the design or results of studies included in the original review.

\section{Terminology}

We use the term study to refer to the conducted research; a study may have one or more corresponding registry records in ClinicalTrials.gov or ICTRP registries, and these study results may be reported in the peer-reviewed literature as publications. A registry record provides basic information about a study's design, and may include optional information on its results or publications associated with it. Studies identified through the registry search may have no associated publications; studies identified by the original report may have no records in a registry. A study was deemed to have been registered prospectively registration of data (defined here as registration of investigational studies prior to enrollment of the first patient or, for observational studies, prior to initial analyses.

\section{Registry Searches}

Because the registry databases are not indexed, queries can include only text words. Thus, it was necessary to translate the search of the original review, which includes text words, as well as controlled-vocabulary (MeSH) terms, to a semantically equivalent query using the registry interfaces. In addition, the ClinicalTrials.gov search interface allows only for queries with a limited number of characters, and documentation on advanced searching options, such as truncation and adjacency searching, is sparse. ${ }^{22,23}$ It is therefore better to search for "intervention" terms only. ${ }^{22}$ We conducted four queries in ClinicalTrials.gov whose union corresponded to the scope of the original search; we used an analogous search process in ICTRP. Appendix A includes the literature searches from the original report and the specific search strategies used in ClinicalTrials.gov and ICTRP.

\section{Screening, Data Extraction, and Data Management}

Registry records were screened using the same approach employed in the original review (Appendix B). An evidence map comprised of registry records for eligible comparative and noncomparative studies was compiled, without minimum sample size or minimum follow up requirements. Basic study information (intervention, outcome, study design, sample size, and follow up duration) was recorded, noting if results were reported in the registry. Additional data was extracted from records that (1) included results and (2) met full eligibility criteria for the original report. These data include detailed study population data, the intervention details (i.e., n3 FA type, dose, and duration), the reported outcomes, the numerical results, and on methodological items to assess the study risk of bias. 
Data were extracted into the same customized forms developed and utilized for the original review in the Systematic Review Data Repository (SRDR) online system (http://srdr.ahrq.gov). Disagreements were resolved by discussion, with adjudication, when necessary, by the original report's project lead.

\section{Analysis}

Our study yield was categorized as follows: 1) registry record present, included in original review; 2) registry record present, not included in original review; and 3) no registry record, included in original review. Characteristics of studies found exclusively in the original review, in a registry database, or in both sources, were documented.

Study initiation date, study status (e.g., discontinued, in progress/ongoing) and, when available, rationale for discontinuation or delay were also documented.

We quantified the number of studies and publications included in the original review but not found to have a registry record. We focused on the value of results data identified via registry searches, and thus in our analyses, we highlight the congruence, or lack thereof, among data identified via the registry and found in the original report in light of additional study data identified via registry searches.

Studies included in the original review and found to have a registry record were reviewed for additional information pertinent to study design (if the registry record includes protocol information) or study findings (if the record includes results). Study design information extracted from the registry record was compared to that extracted from corresponding publications to assess if changes in the outcomes or analysis plan occurred.

Comparisons between registry records and publications were made with respect to 1) general design items used to inform risk of bias assessments and 2) the analysis plan of the eligible exposure-outcome relationships. The risk of bias of each study result in the original review was evaluated based on predefined questions (Appendix C). We assessed whether additional information identified in registry records changed the risk of bias assessments of the original review.

When study results were identified in registry records and in corresponding publications, we determined if the same outcome concepts were employed, and if yes, whether the results agree qualitatively (i.e. same direction). We also describe which outcome measures were reported in the registry record, the publication, or both.

Registry records of newly identified studies (not included in the original review) are summarized in narrative form and added to the original report's evidence map. We applied the same risk of bias assessments as in the original review (Appendix C).

\section{Risk of Bias for the Evidence Base and Strength of Evidence}

For outcomes with new data from the registries for specific n-3 FA comparisons, we reassessed the risk of bias of the evidence base and the strength of evidence using the same methodology used for the original report. We evaluated whether the additional data are likely to impact the findings of the study. We quantified this impact as a potential increase in total study population sample size ( $>20 \%$ ), a change in the magnitude of outcome measures (20\% change in estimate or a change in direction; ideally by meta-analysis), or a change in statistical significance (ideally by meta-analysis). Because meta-analyses were not conducted for most outcomes, we assessed whether the results from the new studies fall within the range of similar studies from the original report. If none of these conditions were met, the additional data were considered 
unlikely to directly impact the strength of evidence or the assessment of risk of bias for the evidence-base. All potential revisions to risk of bias and strength of evidence were discussed with the project lead of the original review. We describe and explain any changes to strength of evidence for any n-3 FA and outcome relationship. 


\section{Results}

\section{Registry Search Yield}

Our initial search yield identified 6826 unique records (5085 in ClinicalTrials.gov, 1741 in ICTRP), (See Figure 1). After initial exclusion criteria were applied, 297 unique records were added to the evidence map and further assessed based on evaluation of basic population, intervention, outcome, study design, sample size criteria, and whether results were reported. At this juncture, 221 studies were excluded in the second round of screening, based on outcomespecific criteria defined in the report, most frequently because the study size was too small (43\%; $n=94)$ for the design ( $<30 /$ arm in randomized controlled trials [RCTs] or $<20$ in crossover studies [XO]), the intervention/exposure was not specifically an n-3 FA (25\%; n=54), or because the study did not evaluate a population of interest (9\%; $n=19)$. A full list of the excluded records and the reasons for exclusion is in Appendix D. A few studies had multiple registry records; one in ClinicalTrials.gov and a second in a national registry of another country listed in the ICTRP.

Figure 1. Literature flow

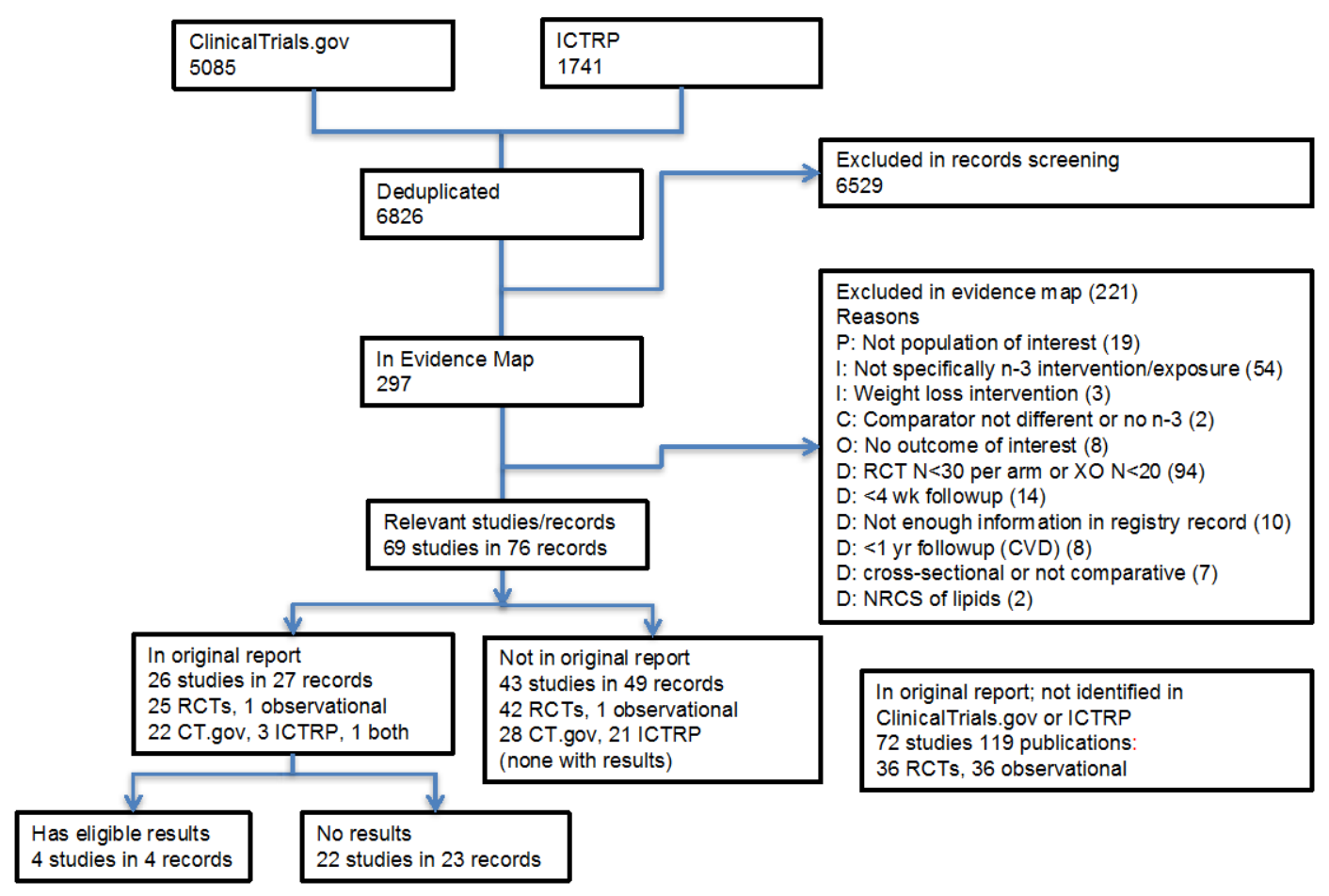

RCT: randomized controlled trial; XO crossover study; CT.gov: ClinicalTrials.gov; ICTRP: International Clinical Trials Registry Platform; CVD: cardiovascular disease; NRCS: non-randomized comparative study. 


\section{Comparison of Registry Searches with Original Review}

The original report included 98 studies (61 randomized controlled trials in 82 articles, and 37 longitudinal observational studies in 65 articles). We compared our registry search yield with our original report to identify studies (1) registry record present, included in original review; (2) registry record present, not included in original review; and (3) no registry record, included in original review. See Figure 1.

\section{Studies Identified via Registry Searches and Found in Original Review}

Overall, 69 studies in 76 records identified through registry searches met full criteria for inclusion in the original report. Of these, 26 studies (in 27 registry records) were included in the original report (25 RCTs, 1 observational Study); 22 of these were found in ClinicalTrials.gov, 3 were found in ICTRP, and 1 was identified in both registries (see Table 1 for the overall description of studies; the subsequent tables highlight differences between registry records and articles). Of the 26 studies in both sources, only 4 studies (in 4 records) included eligible results in the registry records. In general, the agreement between the registry record and the published paper was good when the information was given in both. A fifth record of a factorial study reported results, but no comparison between the n-3 FA and no n-3 FAs was reported in the record. Full information on the comparison of results for the four studies that have them is in the Results section and Table 3 below.

\section{Study Design}

For all 26 studies found in both the report and registries, we were able to extract some study design information via registry records. When possible, study design information extracted from the registry record was compared to corresponding publications to assess if changes in analysis plan occurred. In general, agreement was very good between the registry record and the report, particularly in terms of population and eligibility criteria. There were some small disagreements in study start date, duration of intervention, and reporting of industry relationship when the only role of the sponsor was solely to provide materials. See Appendix E, Tables 1 and 2 for full details.

Table 1. Overall description of studies in both the report and registry from the registry records

\begin{tabular}{|c|c|c|c|c|c|c|c|}
\hline $\begin{array}{l}\text { Study Identifier } \\
\text { Countrylies } \\
\text { Study Name }\end{array}$ & Registry & Population & Dates & $\mathrm{N}$ total & $\begin{array}{l}\text { Study design: } \\
\text { Intervention }\end{array}$ & $\begin{array}{l}\text { Intermediate } \\
\text { Outcomes }\end{array}$ & Clinical Outcomes \\
\hline \multicolumn{8}{|l|}{$\begin{array}{l}\text { Registry record reported } \\
\text { results }\end{array}$} \\
\hline $\begin{array}{l}\text { NCT01242527 } \\
\text { US, Denmark, Netherlands, } \\
\text { Hungary, India, Russia, Ukraine } \\
\text { EVOLVE }\end{array}$ & CT.gov & At risk & $\begin{array}{l}2011- \\
2012\end{array}$ & 399 & $\begin{array}{l}\text { RCT: Fish oil } \\
\text { (EPA+DHA) } 2,3 \text {, or } 4 \\
\text { g/d vs. Placebo }\end{array}$ & Lipids & \\
\hline $\begin{array}{l}\text { NCT01198275 } \\
\text { Italy } \\
\text { ATRIA }\end{array}$ & CT.gov & $\begin{array}{l}\text { CVD, } \\
\text { existing }\end{array}$ & $\begin{array}{l}2006- \\
2008\end{array}$ & 199 & $\begin{array}{l}\text { RCT: Fish oil } \\
\text { (EPA+DHA) 0.850- } \\
0.882 \text { g/d vs. Placebo } \\
\end{array}$ & & Arrhythmia event \\
\hline
\end{tabular}




\begin{tabular}{|c|c|c|c|c|c|c|c|}
\hline $\begin{array}{l}\text { Study Identifier } \\
\text { Countrylies } \\
\text { Study Name } \\
\end{array}$ & Registry & Population & Dates & $\mathrm{N}$ total & $\begin{array}{l}\text { Study design: } \\
\text { Intervention }\end{array}$ & $\begin{array}{l}\text { Intermediate } \\
\text { Outcomes }\end{array}$ & Clinical Outcomes \\
\hline $\begin{array}{l}\text { NCT00781950 } \\
\text { Canada } \\
\text { FLAXPAD }\end{array}$ & CT.gov & $\begin{array}{l}\text { CVD, } \\
\text { existing }\end{array}$ & $\begin{array}{l}2008- \\
2014\end{array}$ & 110 & $\begin{array}{l}\text { RCT: ALA } 30 \mathrm{~g} / \mathrm{d} \text { vs. } \\
\text { Placebo }\end{array}$ & BP, Lipids & $\begin{array}{l}\text { Cardiac event, } \\
\text { Stroke/TIA, Death }\end{array}$ \\
\hline \multicolumn{8}{|l|}{$\begin{array}{l}\text { Registry record did not report } \\
\text { results }\end{array}$} \\
\hline $\begin{array}{l}\text { NCT00005133 } \\
\text { US } \\
\text { CHS }\end{array}$ & CT.gov & Healthy & $\begin{array}{l}1988- \\
2009\end{array}$ & nd & $\begin{array}{l}\text { Observational - } \\
\text { Quantile: unclear n-3 }\end{array}$ & & $\begin{array}{l}\text { Cardiac event, } \\
\text { Stroke/TIA }\end{array}$ \\
\hline $\begin{array}{l}\text { NCT01313988 } \\
\text { Sweden }\end{array}$ & CT.gov & Healthy & $\begin{array}{l}2011- \\
2012\end{array}$ & 332 & $\begin{array}{l}\text { RCT: All n-3 PUFA vs. } \\
\text { Placebo }\end{array}$ & Lipids & \\
\hline $\begin{array}{l}\text { NCT00110838 } \\
\text { Germany, Netherlands, UK, } \\
\text { Austria, Belgium, Czech Republic, } \\
\text { Poland, Switzerland } \\
\text { SOFA }\end{array}$ & CT.gov & Healthy & $\begin{array}{l}2010- \\
2011\end{array}$ & 256 & $\begin{array}{l}\text { RCT: Fish oil } \\
\text { (EPA+DHA) } 2 \text { g/d vs. } \\
\text { Placebo }\end{array}$ & Lipids & \\
\hline $\begin{array}{l}\text { NCT00266292 } \\
\text { Denmark }\end{array}$ & CT.gov & Healthy & $\begin{array}{l}2005- \\
2006\end{array}$ & 60 & $\begin{array}{l}\text { RCT: Fish oil } \\
\text { (EPA+DHA) vs. } \\
\text { Placebo }\end{array}$ & BP, Lipids & \\
\hline $\begin{array}{l}\text { NCT01856179 } \\
\text { Germany }\end{array}$ & CT.gov & Healthy & $\begin{array}{l}2011- \\
2012\end{array}$ & 78 & $\begin{array}{l}\text { RCT: SDA } 15-18 \mathrm{~g} / \mathrm{d} \\
\text { vs. nd }\end{array}$ & Lipids & \\
\hline $\begin{array}{l}\text { NCT00317707 } \\
\text { Italy }\end{array}$ & CT.gov & At risk & $\begin{array}{l}2004- \\
2011\end{array}$ & 12513 & $\begin{array}{l}\text { RCT: All n-3 PUFA vs. } \\
\text { Placebo }\end{array}$ & & $\begin{array}{l}\text { Cardiac event, } \\
\text { Death }\end{array}$ \\
\hline $\begin{array}{l}\text { NCT00141232/ISRCTN76737502 } \\
\text { UK } \\
\text { AFFORD }\end{array}$ & ICTRPI & At risk & $\begin{array}{l}2004- \\
2006\end{array}$ & 810 & $\begin{array}{l}\text { RCT: Fish oil } \\
\text { (EPA+DHA) vs. } \\
\text { Placebo }\end{array}$ & Lipids & \\
\hline $\begin{array}{l}\text { NCT00246701 } \\
\text { US } \\
\text { COMBOS }\end{array}$ & CT.gov & At risk & $\begin{array}{l}2005- \\
2006\end{array}$ & 256 & $\begin{array}{l}\text { RCT: Fish oil } \\
\text { (EPA+DHA) vs. } \\
\text { Placebo }\end{array}$ & Lipids & \\
\hline $\begin{array}{l}\text { NCT00069784 } \\
\text { Canada } \\
\text { ORIGIN }\end{array}$ & CT.gov & At risk & $\begin{array}{l}2003- \\
2011\end{array}$ & 12537 & $\begin{array}{l}\text { RCT: Fish oil } \\
\text { (EPA+DHA) } 0.84 \mathrm{~g} / \mathrm{d} \\
\text { vs. Placebo }\end{array}$ & & $\begin{array}{l}\text { Cardiac event, } \\
\text { Stroke/TIA, Death }\end{array}$ \\
\hline $\begin{array}{l}\text { NCT01758601 } \\
\text { Spain } \\
\text { WISH-CARE }\end{array}$ & CT.gov & At risk & $\begin{array}{l}2010- \\
2012\end{array}$ & 273 & $\begin{array}{l}\text { RCT - XO: Fish oil } \\
\text { (EPA+DHA) } 1 \text { serving } \\
\text { of hake/day vs. no } \\
\text { intervention }\end{array}$ & Lipids & \\
\hline $\begin{array}{l}\text { NCT00231738 } \\
\text { Japan } \\
\text { JELIS }\end{array}$ & CT.gov & At risk & $\begin{array}{l}1996- \\
2004\end{array}$ & 18000 & $\begin{array}{l}\text { RCT: EPA } 1.8 \mathrm{~g} / \mathrm{d} \text { vs. } \\
\text { nd }\end{array}$ & & $\begin{array}{l}\text { Cardiac event, } \\
\text { Stroke/TIA, Death }\end{array}$ \\
\hline $\begin{array}{l}\text { NCT01047501 } \\
\text { US } \\
\text { ANCHOR }\end{array}$ & CT.gov & At risk & $\begin{array}{l}2009- \\
2011\end{array}$ & 702 & $\begin{array}{l}\text { RCT: EPA } 2 \text { or } 4 \mathrm{~g} / \mathrm{d} \\
\text { vs. Placebo }\end{array}$ & Lipids & \\
\hline $\begin{array}{l}\text { NCT01351012 } \\
\text { Canada } \\
\text { COMIT }\end{array}$ & CT.gov & At risk & $\begin{array}{l}2010- \\
2012\end{array}$ & 140 & $\begin{array}{l}\text { RCT - XO: ALA, DHA + } \\
\text { ALA DHA 7.2, ALA 4.2- } \\
\text { 13.8 vs. ALA 4.2-13.8 } \\
\mathrm{g} / \mathrm{d}\end{array}$ & Lipids & \\
\hline $\begin{array}{l}\text { DRKS00006232 } \\
\text { Germany } \\
\text { MSX }\end{array}$ & CT.gov & At risk & $\begin{array}{l}2009- \\
2009\end{array}$ & 81 & $\begin{array}{l}\text { RCT: ALA } 3.5 \mathrm{~g} / \mathrm{d} \text { vs. } \\
\text { ALA } 0.9 \mathrm{~g} / \mathrm{d}\end{array}$ & BP, Lipids & \\
\hline $\begin{array}{l}\text { NCT00004558 } \\
\text { US }\end{array}$ & ICTRP & $\begin{array}{l}C V D, \\
\text { existing }\end{array}$ & $\begin{array}{l}1999- \\
2004\end{array}$ & 200 & $\begin{array}{l}\text { RCT: Omega-3 } \\
\text { (Unspecified) vs. } \\
\text { Placebo }\end{array}$ & & Arrhythmia event \\
\hline $\begin{array}{l}\text { NCT00127452 } \\
\text { Netherlands } \\
\text { Alpha Omega }\end{array}$ & CT.gov & $\begin{array}{l}C V D, \\
\text { existing }\end{array}$ & $\begin{array}{l}2002- \\
2010\end{array}$ & 4837 & $\begin{array}{l}\text { RCT: All n-3 PUFA Fish } \\
\text { oil } 0.4 \mathrm{~g} / \mathrm{d}, \text { ALA } 2 \mathrm{~g} / \mathrm{d} \\
\text { vs. Placebo }\end{array}$ & & $\begin{array}{l}\text { Cardiac event, } \\
\text { Stroke/TIA, } \\
\text { Arrhythmia event, } \\
\text { PVD event, Death }\end{array}$ \\
\hline
\end{tabular}




\begin{tabular}{|c|c|c|c|c|c|c|c|}
\hline $\begin{array}{l}\text { Study Identifier } \\
\text { Countrylies } \\
\text { Study Name }\end{array}$ & Registry & Population & Dates & $\mathrm{N}$ total & $\begin{array}{l}\text { Study design: } \\
\text { Intervention }\end{array}$ & $\begin{array}{l}\text { Intermediate } \\
\text { Outcomes }\end{array}$ & Clinical Outcomes \\
\hline $\begin{array}{l}\text { NCTO0251134 } \\
\text { Germany } \\
\text { OMEGA }\end{array}$ & CT.gov & $\begin{array}{l}\text { CVD, } \\
\text { existing }\end{array}$ & $\begin{array}{l}2003- \\
2008\end{array}$ & 3800 & $\begin{array}{l}\text { RCT: All n-3 PUFA } 1 \\
\text { g/d vs. Placebo }\end{array}$ & & $\begin{array}{l}\text { Cardiac event, } \\
\text { Arrhythmia event, } \\
\text { Death }\end{array}$ \\
\hline $\begin{array}{l}\text { NCT00336336 } \\
\text { Italy } \\
\text { GISSI-HF }\end{array}$ & CT.gov & $\begin{array}{l}\text { CVD, } \\
\text { existing }\end{array}$ & $\begin{array}{l}2002- \\
2008\end{array}$ & 6975 & $\begin{array}{l}\text { RCT: All n-3 PUFA } 1 \\
\text { g/d vs. Placebo }\end{array}$ & & $\begin{array}{l}\text { Cardiac event, } \\
\text { Stroke/TIA, } \\
\text { Arrhythmia event, } \\
\text { Death }\end{array}$ \\
\hline $\begin{array}{l}\text { ISRCTN41926726 } \\
\text { France } \\
\text { SU.FOL.OM3 }\end{array}$ & CT.gov & $\begin{array}{l}\text { CVD, } \\
\text { existing }\end{array}$ & $\begin{array}{l}2003- \\
2009\end{array}$ & 2400 & $\begin{array}{l}\text { RCT: Fish oil } \\
\text { (EPA+DHA) } 0.6 \mathrm{~g} / \mathrm{d} \text { vs. } \\
\text { Placebo }\end{array}$ & & $\begin{array}{l}\text { Cardiac event, } \\
\text { Stroke/TIA, Death }\end{array}$ \\
\hline $\begin{array}{l}\text { ISRCTN66664610 } \\
\text { UK } \\
\text { MARINA }\end{array}$ & ICTRP & $\begin{array}{l}\text { CVD, } \\
\text { existing }\end{array}$ & $\begin{array}{l}2008- \\
2010\end{array}$ & 360 & $\begin{array}{l}\text { RCT: Fish oil } \\
\text { (EPA+DHA) 0.45, 0.9, } \\
\text { or } 1.8 \mathrm{~g} / \mathrm{d} \text { vs. Placebo }\end{array}$ & BP, Lipids & \\
\hline $\begin{array}{l}\text { NCT00004559 } \\
\text { US } \\
\text { FAAT }\end{array}$ & ICTRP & $\begin{array}{l}\text { CVD, } \\
\text { existing }\end{array}$ & $\begin{array}{l}2000- \\
2005\end{array}$ & nd & $\begin{array}{l}\text { RCT: Fish oil } \\
(\text { EPA+DHA) } 4 \text { g/d vs. } \\
\text { Placebo }\end{array}$ & & Arrhythmia event \\
\hline $\begin{array}{l}\text { NCT00597220 } \\
\text { Argentinia } \\
\text { FORWARD }\end{array}$ & CT.gov & $\begin{array}{l}\text { CVD, } \\
\text { existing }\end{array}$ & $\begin{array}{l}2008- \\
2011\end{array}$ & 1600 & $\begin{array}{l}\text { RCT: Fish oil } \\
(\text { EPA+DHA) } 1 \mathrm{~g} / \mathrm{d} \text { vs. } \\
\text { Placebo }\end{array}$ & & $\begin{array}{l}\text { Stroke/TIA, } \\
\text { Arrhythmia event }\end{array}$ \\
\hline
\end{tabular}

RCT: randomized controlled trial; XO: crossover tiral; CT.gov: ClinicalTrials.gov; ICTRP: International Clinical Trials Registry Platform; CVD: cardiovascular disease; NRCS: non-randomized comparative study; TIA: transient ischemic attack; PVD: peripheral vascular disease; BP: blood pressure; EPA: eicosapentaenoic acid; DHA: docosahexaenoic acid; ALA: alphalinolenic acid; PUFA: polyunsaturated fatty acids; SDA: stearidonic acid

\section{Outcomes}

Outcomes of interest described in the original review (see Appendix B), were identified in registry records and in publications and compared. Registry records include data entry fields for primary and secondary outcomes and these measures were extracted and characterized as such. Disposition of primary outcomes found in publications were determined if they were 1) explicitly stated as such, 2) the outcome used in reported power calculations, or 3) where implied by focus of the original article.

We identified several discrepancies between outcomes reported in registry records and resulting publications (Table 2). The overwhelming number discrepancies (24 outcomes in 12 papers) had to do with more outcomes being reported in the paper than were prespecified in the record. In general, these were intermediate outcomes (e.g., lipids and blood pressure), though in three papers they were clinical outcomes, including nonfatal stroke, myocardial infarction, and revascularization, among others). All of the added clinical and blood pressure outcomes were reported as not having a significant difference between groups. As would be expected, triglycerides were consistently reported as significantly favoring the Omega-3 group, but cholesterol overall showed a nonsignificant difference.

In three cases, a record prespecified a clinical outcome as primary, and it was either reported as secondary or not at all in the paper. In the study by Bosch, the prespecified outcome was a composite of "the First Occurrence of Cardiovascular (CV) Death, Nonfatal Myocardial Infarction, Nonfatal Stroke, Revascularization Procedure or Hospitalization for Heart Failure.” All of these outcomes were reported in the paper as secondary outcomes, except Cardiovascular (CV) Death, which was reported as primary. None of these results was significantly different between groups. ${ }^{24}$ The paper by Damsgaard reported the prespecified lipid outcomes, which were not significant, but not the prespecified blood pressure outcomes. ${ }^{25}$ For the study by Rodriguez-Leyva, we went to their published protocol, ${ }^{26}$ which differed from the record in two 
outcomes (total and CVD mortality), which were reported as not significantly different between groups in the paper. Both of these outcomes were specified as primary in the record and secondary in the published protocol. It is worth noting that the paper also reported nonsignificant differences for the other two primary outcomes (stroke and MI). In general, this suggests that there is probably not major problem with selective outcome reporting in this body of literature. ${ }^{27}$

Table 2. Outcome discrepancies

\begin{tabular}{|c|c|c|c|c|c|}
\hline $\begin{array}{l}\text { Study name, Date, } \\
\text { PMID, Registry } \\
\text { number }\end{array}$ & $\begin{array}{l}\mathrm{N} \text { record/N } \\
\text { publication }\end{array}$ & $\begin{array}{l}\text { Current prespecified } \\
\text { outcome (from } \\
\text { registry) }\end{array}$ & $\begin{array}{l}\text { In papers (as } \\
\text { primaryl } \\
\text { secondary) (time } \\
\text { point) }\end{array}$ & $\begin{array}{l}\text { In Registry Record (as } \\
\text { primary/secondary) (time } \\
\text { point) }\end{array}$ & $\begin{array}{l}\text { Outcome } \\
\text { (favors n-3, } \\
\text { favors other, } \\
\text { not significant } \\
\text { (NS), results } \\
\text { not reported } \\
\text { (ND)) }\end{array}$ \\
\hline \multirow{2}{*}{$\begin{array}{l}\text { Baxheinrich, 2012, } \\
\text { 22894911, } \\
\text { DRKS00006232 }\end{array}$} & \multirow[t]{2}{*}{$81 / 81$} & Blood pressure & $\begin{array}{l}\text { Secondary ( } 3 \text { and } 6 \\
\text { months) }\end{array}$ & $\begin{array}{l}\text { Secondary ( } 3 \text { and } 6 \\
\text { months) }\end{array}$ & Favors n-3 \\
\hline & & Lipids & $\begin{array}{l}\text { Secondary ( } 3 \text { and } 6 \\
\text { months) }\end{array}$ & $\begin{array}{l}\text { Secondary ( } 3 \text { and } 6 \\
\text { months) }\end{array}$ & $\begin{array}{l}\text { Favors } n-3 \text { for } \\
\text { TG; NS for } \\
\text { others }\end{array}$ \\
\hline \multirow[t]{5}{*}{$\begin{array}{l}\text { Bosch, 2012, } \\
22686415, \\
\text { NCT00069784 }\end{array}$} & \multirow[t]{5}{*}{$\begin{array}{l}12537 / \\
12536\end{array}$} & $\begin{array}{l}\text { MACE: Composite of the } \\
\text { First Occurrence of } \\
\text { Cardiovascular (CV) } \\
\text { Death, Nonfatal } \\
\text { Myocardial Infarction, } \\
\text { Nonfatal Stroke, } \\
\text { Revascularization } \\
\text { Procedure or } \\
\text { Hospitalization for Heart } \\
\text { Failure }\end{array}$ & $\begin{array}{l}\text { Secondary (6+ } \\
\text { years), except for } \\
\text { "death from } \\
\text { cardiovascular } \\
\text { causes'" which is } \\
\text { also primary in the } \\
\text { paper }\end{array}$ & Primary (mean 6.2 years) & NS \\
\hline & & $\begin{array}{l}\text { Death from } \\
\text { cardiovascular causes }\end{array}$ & Primary (6+ years) & Primary (mean 6.2 years) & NS \\
\hline & & $\begin{array}{l}\text { Total mortality (all } \\
\text { causes) }\end{array}$ & $\begin{array}{l}\text { Secondary }(6+ \\
\text { years })\end{array}$ & $\begin{array}{l}\text { Secondary (mean } 6.2 \\
\text { years) }\end{array}$ & NS \\
\hline & & Lipids & $\begin{array}{l}\text { Secondary }(6+ \\
\text { years) }\end{array}$ & & NS \\
\hline & & Blood pressure & $\begin{array}{l}\text { Secondary }(6+ \\
\text { years) }\end{array}$ & & NS \\
\hline \multirow{2}{*}{$\begin{array}{l}\text { Brinton, 2013, } \\
23835245, \\
\text { NCT01047501 }\end{array}$} & \multirow[t]{2}{*}{$702 / 687$} & Lipids (Tg) & Primary (3 months) & Primary (12 weeks) & Favors n-3 \\
\hline & & Lipids (other) & $\begin{array}{l}\text { Secondary (3 } \\
\text { months) }\end{array}$ & Secondary (12 weeks) & Favors $n-3$ \\
\hline \multirow[t]{5}{*}{$\begin{array}{l}\text { Brouwer, 2006, } \\
\text { 16772624, } \\
\text { NCT00110838 }\end{array}$} & \multirow[t]{5}{*}{$546 / 546$} & $\begin{array}{l}\text { ICD intervention/device } \\
\text { insertion }\end{array}$ & Primary (1 year) & Primary (1 year) & NS \\
\hline & & $\begin{array}{l}\text { Total mortality (all } \\
\text { causes) }\end{array}$ & Secondary (1 year) & Secondary (1 year) & NS \\
\hline & & Myocardial infarction & Secondary (1 year) & Secondary (1 year) & NS \\
\hline & & Cardiac mortality & Secondary (1 year) & Secondary (1 year) & NS \\
\hline & & $\begin{array}{l}\text { Arrythmic events } \\
\text { (VF/NT) }\end{array}$ & Secondary (1 year) & Secondary (1 year) & NS \\
\hline \multirow{2}{*}{$\begin{array}{l}\text { Damsgaard, 2008, } \\
\text { 18492834, } \\
\text { NCT00266292 }\end{array}$} & \multirow[t]{2}{*}{$60 / 64$} & Lipids & Primary (8 weeks) & Primary (2 months) & NS \\
\hline & & Blood pressure & & Primary (2 months) & ND \\
\hline $\begin{array}{l}\text { Galan, 2010, } \\
21115589, \\
\text { ISRCTN41926726 }\end{array}$ & $2400 / 2501$ & $\begin{array}{l}\text { MACE: Combination of } \\
\text { myocardial infarction, } \\
\text { cerebral vascular }\end{array}$ & $\begin{array}{l}\text { Primary (median } 4.7 \\
\text { years) }\end{array}$ & Primary (nd) & NS \\
\hline
\end{tabular}




\begin{tabular}{|c|c|c|c|c|c|}
\hline $\begin{array}{l}\text { Study name, Date, } \\
\text { PMID, Registry } \\
\text { number }\end{array}$ & $\begin{array}{l}\mathrm{N} \text { record/N } \\
\text { publication }\end{array}$ & $\begin{array}{l}\text { Current prespecified } \\
\text { outcome (from } \\
\text { registry) }\end{array}$ & $\begin{array}{l}\text { In papers (as } \\
\text { primaryl } \\
\text { secondary) (time } \\
\text { point) }\end{array}$ & $\begin{array}{l}\text { In Registry Record (as } \\
\text { primarylsecondary) (time } \\
\text { point) }\end{array}$ & $\begin{array}{l}\text { Outcome } \\
\text { (favors n-3, } \\
\text { favors other, } \\
\text { not significant } \\
\text { (NS), results } \\
\text { not reported } \\
\text { (ND)) }\end{array}$ \\
\hline & & $\begin{array}{l}\text { ischemic accident or } \\
\text { cardiovascular deaths }\end{array}$ & & & \\
\hline & & $\begin{array}{l}\text { Total mortality (all } \\
\text { causes) }\end{array}$ & $\begin{array}{l}\text { Secondary (median } \\
4.7 \text { years) }\end{array}$ & Secondary (nd) & Favors other \\
\hline & & CVD mortality & $\begin{array}{l}\text { Secondary (median } \\
4.7 \text { years) }\end{array}$ & Secondary (nd) & NS \\
\hline & & Myocardial infarction & $\begin{array}{l}\text { Secondary (median } \\
4.7 \text { years) }\end{array}$ & Secondary (nd) & NS \\
\hline & & $\begin{array}{l}\text { Acute Coronary } \\
\text { Syndrome }\end{array}$ & $\begin{array}{l}\text { Secondary (median } \\
4.7 \text { years); as part } \\
\text { of a composite } \\
\text { outcome }\end{array}$ & Secondary (nd) & NS \\
\hline & & $\begin{array}{l}\text { Ischemic cerebral } \\
\text { vascular accidents } \\
\text { (stroke) }\end{array}$ & $\begin{array}{l}\text { Secondary (median } \\
4.7 \text { years) }\end{array}$ & Secondary (nd) & NS \\
\hline & & Revascularization & $\begin{array}{l}\text { Secondary (median } \\
4.7 \text { years) }\end{array}$ & Secondary (nd) & NS \\
\hline \multirow{2}{*}{$\begin{array}{l}\text { Holman, 2009, } \\
\text { 19002433, } \\
\text { NCT00141232 and } \\
\text { ISRCTN76737502 }\end{array}$} & \multirow[t]{2}{*}{$810 / 658$} & Lipids (Tg) & Primary (4 months) & Primary (4 months) & Favors $n-3$ \\
\hline & & Blood pressure & $\begin{array}{l}\text { Secondary (4 } \\
\text { months) }\end{array}$ & & NS \\
\hline \multirow{2}{*}{$\begin{array}{l}\text { Jones, 2014, } \\
24829493, \\
\text { NCT01351012 }\end{array}$} & \multirow[t]{2}{*}{$140 / 130$} & Lipids & $\begin{array}{l}\text { Secondary (4 } \\
\text { weeks) }\end{array}$ & Secondary (4 weeks) & Favors $n-3$ \\
\hline & & Blood pressure & $\begin{array}{l}\text { Secondary (4 } \\
\text { weeks) }\end{array}$ & Secondary (4 weeks) & Favors $n-3$ \\
\hline \multirow{2}{*}{$\begin{array}{l}\text { Kastelein, 2014, } \\
\text { 24528690, } \\
\text { NCT01242527 }\end{array}$} & \multirow[t]{2}{*}{$399 / 393$} & Lipids (Tg) & Primary (12 weeks) & Primary (12 weeks) & Favors n-3 \\
\hline & & Lipids (other) & $\begin{array}{l}\text { Secondary (12 } \\
\text { weeks) }\end{array}$ & & Favors n-3 \\
\hline \multirow[t]{7}{*}{$\begin{array}{l}\text { Kromhout, 2010, } \\
\text { 20929341, } \\
\text { NCT00127452 }\end{array}$} & \multirow[t]{7}{*}{$4837 / 4837$} & $\begin{array}{l}\text { Major cardiovascular } \\
\text { events, which comprises } \\
\text { fatal cardiovascular } \\
\text { diseases (CVD), non- } \\
\text { fatal myocardial } \\
\text { infarction, non-fatal } \\
\text { cardiac arrest, non-fatal } \\
\text { stroke and cardiac } \\
\text { interventions (PCl and } \\
\text { CABG) }\end{array}$ & $\begin{array}{l}\text { Primary (40 } \\
\text { months) }\end{array}$ & Primary (40 months) & NS \\
\hline & & $\begin{array}{l}\text { cardiovascular diseases } \\
\text { (CVD }\end{array}$ & $\begin{array}{l}\text { Secondary (40 } \\
\text { months) }\end{array}$ & Secondary (40 months) & NS \\
\hline & & Cardiac mortality & $\begin{array}{l}\text { Secondary (40 } \\
\text { months) }\end{array}$ & Secondary (40 months) & NS \\
\hline & & Arrythmia & $\begin{array}{l}\text { Secondary (40 } \\
\text { months) }\end{array}$ & & NS \\
\hline & & $\begin{array}{l}\text { Total mortality (all } \\
\text { causes) }\end{array}$ & $\begin{array}{l}\text { Secondary (40 } \\
\text { months) }\end{array}$ & Secondary (40 months) & NS \\
\hline & & Lipids (in appendix) & $\begin{array}{l}\text { Secondary ( } 40 \\
\text { months) }\end{array}$ & & NS \\
\hline & & Blood pressure (in & Secondary (40 & & NS \\
\hline
\end{tabular}




\begin{tabular}{|c|c|c|c|c|c|}
\hline $\begin{array}{l}\text { Study name, Date, } \\
\text { PMID, Registry } \\
\text { number }\end{array}$ & $\begin{array}{l}\mathrm{N} \text { record/N } \\
\text { publication }\end{array}$ & $\begin{array}{l}\text { Current prespecified } \\
\text { outcome (from } \\
\text { registry) }\end{array}$ & $\begin{array}{l}\text { In papers (as } \\
\text { primaryl } \\
\text { secondary) (time } \\
\text { point) }\end{array}$ & $\begin{array}{l}\text { In Registry Record (as } \\
\text { primary/secondary) (time } \\
\text { point) }\end{array}$ & $\begin{array}{l}\text { Outcome } \\
\text { (favors n-3, } \\
\text { favors other, } \\
\text { not significant } \\
\text { (NS), results } \\
\text { not reported } \\
\text { (ND)) }\end{array}$ \\
\hline & & appendix) & months) & & \\
\hline \multirow[t]{3}{*}{$\begin{array}{l}\text { Kuhnt 2014, } \\
24553695, \\
\text { NCT01856179 }\end{array}$} & \multirow[t]{3}{*}{$78 / 59$} & EPA concentrations & Primary (56 days) & Primary (2 months) & $\begin{array}{l}\text { N/A (not an } \\
\text { outcome of } \\
\text { interest for the } \\
\text { report) }\end{array}$ \\
\hline & & Lipids & $\begin{array}{l}\text { Secondary (2 } \\
\text { months) }\end{array}$ & & Favors n-3 \\
\hline & & Blood pressure & $\begin{array}{l}\text { Secondary (2 } \\
\text { months) }\end{array}$ & & Favors n-3 \\
\hline \multirow{4}{*}{$\begin{array}{l}\text { Leaf, 2005, } \\
\text { 16267249, } \\
\text { NCT00004559 }\end{array}$} & \multirow[t]{4}{*}{$\mathrm{Nd} / 402$} & VT or VF event & $\begin{array}{l}\text { Primary (12 } \\
\text { months) }\end{array}$ & Primary (nd) & NS \\
\hline & & $\begin{array}{l}\text { Total mortality (all } \\
\text { causes) }\end{array}$ & Secondary (1 year) & & NS \\
\hline & & Cardiac mortality & Secondary (1 year) & & NS \\
\hline & & Sudden cardiac death & Secondary (1 year) & & NS \\
\hline \multirow{5}{*}{$\begin{array}{l}\text { Macchia, 2013, } \\
\text { 23265344, } \\
\text { NCT00597220 }\end{array}$} & \multirow[t]{5}{*}{$1600 / 586$} & Atrial fibrillation & $\begin{array}{l}\text { Primary (12 } \\
\text { months) }\end{array}$ & Primary (12 months) & NS \\
\hline & & $\begin{array}{l}\text { Total mortality (all } \\
\text { causes) }\end{array}$ & $\begin{array}{l}\text { Secondary (12 } \\
\text { months) }\end{array}$ & Secondary (12 months) & NS \\
\hline & & $\begin{array}{l}\text { MACE: all-cause } \\
\text { mortality, nonfatal } \\
\text { stroke, nonfatal acute } \\
\text { myocardial infarction } \\
\text { (AMI), systemic } \\
\text { embolism, heart failure } \\
\text { development, or severe } \\
\text { bleeding }\end{array}$ & $\begin{array}{l}\text { Secondary (12 } \\
\text { months) }\end{array}$ & & NS \\
\hline & & $\begin{array}{l}\text { hospitalizations for CV } \\
\text { reasons }\end{array}$ & $\begin{array}{l}\text { Secondary (12 } \\
\text { months) }\end{array}$ & Secondary (12 months) & NS \\
\hline & & Thromboembolism & $\begin{array}{l}\text { Secondary (12 } \\
\text { months) }\end{array}$ & Secondary (12 months) & NS \\
\hline $\begin{array}{l}\text { Maki, 2010, } \\
20451686, \\
\text { NCT00246701 }\end{array}$ & $256 / 254$ & Lipids & Primary (8 weeks) & Primary (8 weeks) & Favors n-3 \\
\hline $\begin{array}{l}\text { Maki, 2013, } \\
\text { 23998969, } \\
\text { NCT01408303 } \\
\end{array}$ & $646 / 627$ & Lipids & $\begin{array}{l}\text { Primary (1.5 } \\
\text { months) }\end{array}$ & Primary (6 weeks) & Favors n-3 \\
\hline \multirow[t]{2}{*}{$\begin{array}{l}\text { Nodari, 2011, } \\
21844082, \\
\text { NCT01198275 }\end{array}$} & \multirow[t]{2}{*}{$199 / 133$} & $\begin{array}{l}\text { Atrial fibrillation } \\
\text { (maintenance of sinus } \\
\text { rhythm) }\end{array}$ & Primary (1 year) & Primary (1 year) & Favors n-3 \\
\hline & & $\begin{array}{l}\text { Time to a First } \\
\text { Recurrence of Atrial } \\
\text { fibrillation }\end{array}$ & $\begin{array}{l}\text { Secondary (median } \\
718 \text { days) }\end{array}$ & Secondary (12 months) & Favors n-3 \\
\hline \multirow{6}{*}{$\begin{array}{l}\text { Raitt, 2005, } \\
\text { 15956633, } \\
\text { NCT00004558 }\end{array}$} & \multirow[t]{6}{*}{$200 / 200$} & VT or VF & $\begin{array}{l}\text { Primary (median of } \\
718 \text { days) }\end{array}$ & Primary (nd) & NS \\
\hline & & $\begin{array}{l}\text { Total mortality (all } \\
\text { causes) }\end{array}$ & Secondary (2 years) & Secondary (nd) & NS \\
\hline & & Hospitalization rates & Secondary (2 years) & Secondary (nd) & NS \\
\hline & & Cardiac mortality & Secondary (2 years) & & NS \\
\hline & & Sudden Cardiac Death & Secondary (2 years) & & NS \\
\hline & & Revascularization & Secondary (2 years) & & NS \\
\hline
\end{tabular}




\begin{tabular}{|c|c|c|c|c|c|}
\hline $\begin{array}{l}\text { Study name, Date, } \\
\text { PMID, Registry } \\
\text { number }\end{array}$ & $\begin{array}{l}\mathrm{N} \text { record } / \mathrm{N} \\
\text { publication }\end{array}$ & $\begin{array}{l}\text { Current prespecified } \\
\text { outcome (from } \\
\text { registry) }\end{array}$ & $\begin{array}{l}\text { In papers (as } \\
\text { primaryl } \\
\text { secondary) (time } \\
\text { point) }\end{array}$ & $\begin{array}{l}\text { In Registry Record (as } \\
\text { primary/secondary) (time } \\
\text { point) }\end{array}$ & $\begin{array}{l}\text { Outcome } \\
\text { (favors n-3, } \\
\text { favors other, } \\
\text { not significant } \\
\text { (NS), results } \\
\text { not reported } \\
\text { (ND)) }\end{array}$ \\
\hline & & Myocardial infarction & Secondary (2 years) & & NS \\
\hline $\begin{array}{l}\text { Ras, 2014, } \\
\text { 25122648, } \\
\text { NCT01313988 }\end{array}$ & $332 / 314$ & Lipids (Tg) & Primary (1 month) & Primary (4 weeks) & Favors $n-3$ \\
\hline \multirow{7}{*}{$\begin{array}{l}\text { Rauch, 2010, } \\
21060071, \\
\text { NCT00251134 }\end{array}$} & \multirow[t]{7}{*}{$3800 / 3804$} & Sudden cardiac death & Primary (1 year) & Primary (12 months) & NS \\
\hline & & $\begin{array}{l}\text { Total mortality (all } \\
\text { causes) }\end{array}$ & Secondary (1 year) & Secondary (12 months) & NS \\
\hline & & $\begin{array}{l}\text { MACCE: Total mortality, } \\
\text { re-infarction or stroke }\end{array}$ & Secondary (1 year) & Secondary (12 months) & NS \\
\hline & & Total rehospitalisation & Secondary (1 year) & Secondary (12 months) & NS \\
\hline & & VT or VF & Secondary (1 year) & Secondary (12 months) & NS \\
\hline & & $\begin{array}{l}\text { Arrhythmia device } \\
\text { insertion }\end{array}$ & Secondary (1 year) & Secondary (12 months) & Favors other \\
\hline & & Revascularization & Secondary (1 year) & Secondary (12 months) & NS \\
\hline \multirow{6}{*}{$\begin{array}{l}\text { Rodriguez-Leyva, } \\
\text { 2013, 24126178, } \\
\text { NCT00781950 } \\
\text { (outcome information } \\
\text { from published } \\
\text { protocol, PMID } \\
\text { 21616170) }\end{array}$} & \multirow[t]{6}{*}{$110 / 87$} & $\begin{array}{l}\text { Total mortality (all } \\
\text { causes) }\end{array}$ & Secondary (1 year) & Primary (1 year) & NS \\
\hline & & CVD mortality & Secondary (1 year) & Primary (1 year) & NS \\
\hline & & Stroke & Primary (1 year) & Primary (1 year) & NS \\
\hline & & Myocardial infarction & Primary (1 year) & Primary (1 year) & NS \\
\hline & & Blood pressure & $\begin{array}{l}\text { Secondary }(1,6, \\
\text { and } 12 \text { months) }\end{array}$ & Secondary (1 year) & Favors $n-3$ \\
\hline & & Lipids & $\begin{array}{l}\text { Secondary (1, } 6 \text {, } \\
\text { and } 12 \text { months) }\end{array}$ & Secondary (1 year) & ND \\
\hline \multirow[t]{3}{*}{$\begin{array}{l}\text { Roncaglioni, 2013, } \\
\text { 23656645, } \\
\text { NCT00317707 }\end{array}$} & \multirow[t]{3}{*}{$\begin{array}{l}12513 / \\
12513\end{array}$} & $\begin{array}{l}\text { MACE: death from } \\
\text { cardiovascular causes } \\
\text { or hospital admission } \\
\text { from cardiovascular } \\
\text { causes }\end{array}$ & Primary (5 years) & Primary (5 years) & NS \\
\hline & & Lipids (in appendix) & Secondary (5 years) & & Favors n-3 \\
\hline & & $\begin{array}{l}\text { Blood pressure (in } \\
\text { appendix) }\end{array}$ & Secondary (5 years) & & NS \\
\hline \multirow[t]{2}{*}{$\begin{array}{l}\text { Sanders, 2011, } \\
\text { 21865334, } \\
\text { ISRCTN66664610 }\end{array}$} & \multirow[t]{2}{*}{$360 / 310$} & Lipids & Secondary (1 year) & $\begin{array}{l}\text { Secondary (6 months, } 12 \\
\text { months) }\end{array}$ & Favors $n-3$ \\
\hline & & Blood pressure & Secondary (1 year) & & NS \\
\hline \multirow{4}{*}{$\begin{array}{l}\text { Tavazzi, 2008, } \\
\text { 18757090, } \\
\text { NCT00336336 }\end{array}$} & \multirow[t]{4}{*}{$6975 / 6975$} & $\begin{array}{l}\text { Total mortality (all } \\
\text { causes) }\end{array}$ & $\begin{array}{l}\text { Primary (stated) } \\
\text { (3.9 years) }\end{array}$ & $\begin{array}{l}\text { Primary (from enrollment to } \\
1252 \text { deaths in R2 arm) }\end{array}$ & NS \\
\hline & & $\begin{array}{l}\text { Total mortality (all } \\
\text { causes) or } \\
\text { hospitalization for any } \\
\text { reason }\end{array}$ & & $\begin{array}{l}\text { Primary (from enrollment to } \\
1252 \text { deaths in } \mathrm{R} 2 \mathrm{arm} \text { ) }\end{array}$ & $\begin{array}{l}\text { Favors } n-3 \\
\text { (when adjusted) }\end{array}$ \\
\hline & & CVD mortality & $\begin{array}{l}\text { Secondary ( } 3.9 \\
\text { years) }\end{array}$ & $\begin{array}{l}\text { Secondary (from } \\
\text { enrollment to } 1252 \text { deaths } \\
\text { in R2 arm) }\end{array}$ & $\begin{array}{l}\text { Favors } n-3 \\
\text { (when adjusted) }\end{array}$ \\
\hline & & $\begin{array}{l}\text { Hospitalization for any } \\
\text { reason }\end{array}$ & $\begin{array}{l}\text { Secondary ( } 3.9 \\
\text { years) }\end{array}$ & $\begin{array}{l}\text { Secondary (from } \\
\text { enrollment to } 1252 \text { deaths }\end{array}$ & $\begin{array}{l}\text { Favors n-3 } \\
\text { (when adjusted) }\end{array}$ \\
\hline
\end{tabular}




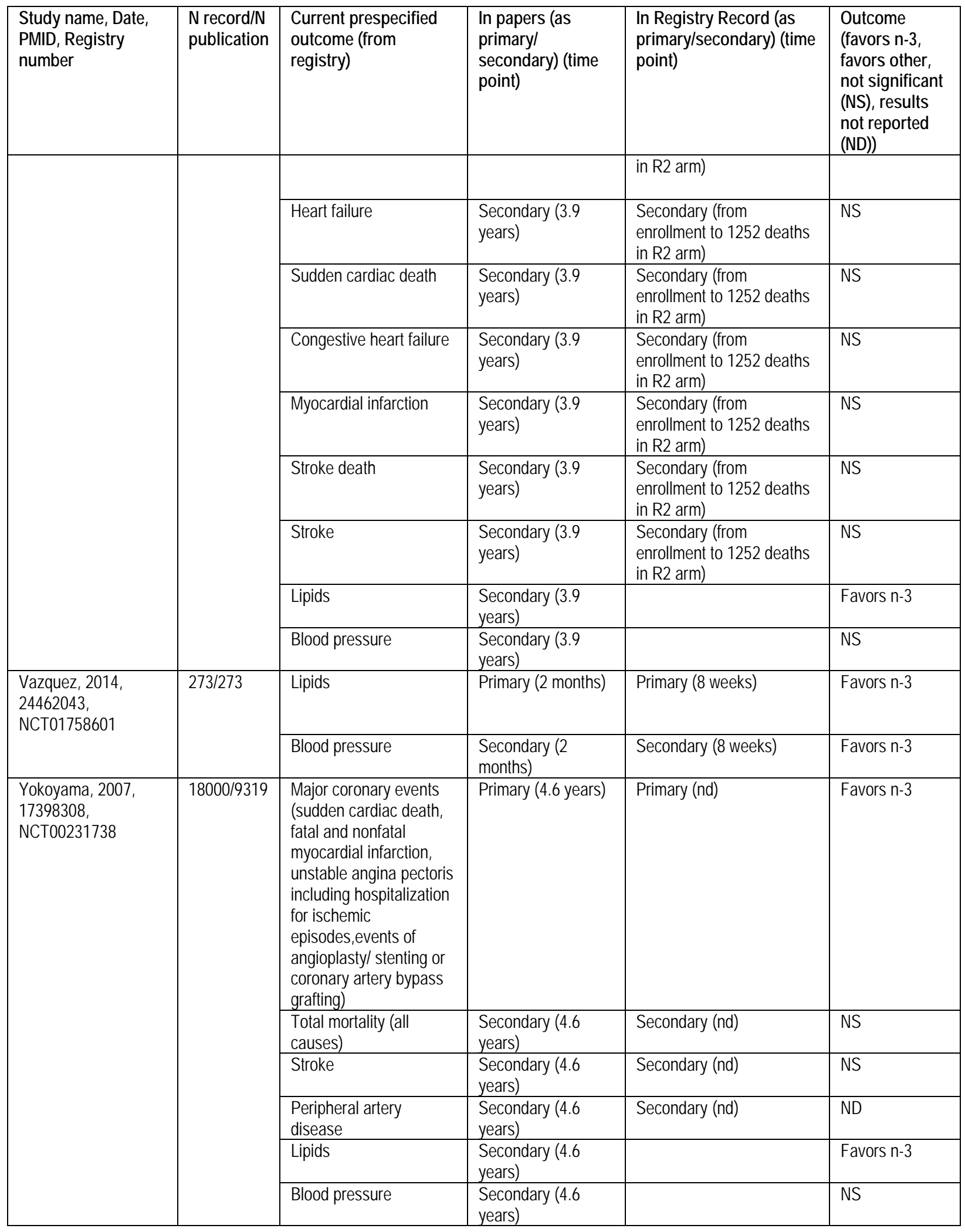




\section{Baselines}

For the four studies that had results data in both the registry record and publications, ${ }^{27-30}$ baseline data, results, and adverse events were compared. The baseline data provided in registry records were limited to age, gender, and in one record ${ }^{29}$ race. All of the baselines provided matched the corresponding publications exactly (for further details, see Appendix E, Table E-5).

\section{Results}

The results, as reported in both the records and the publications, are given in Table 3 . In one paper there was a discrepancy in how the results were reported, which lead to a difference in significance. ${ }^{30}$ However, the significant results were reported in the registry record, while the non-significant findings were reported in the paper, so there is little indication of reporting bias. In addition, the odds ratio reported in the record falls within the confidence intervals of that in the report, and so is unlikely to differ in either direction or magnitude.

In a second study, the record and the paper do not agree in terms of outcomes reported or results given. ${ }^{27}$ This is a recent study so it is possible that the paper for the clinical outcomes is still in process. One outcome, all-cause mortality, was given in the record but not in either paper. This outcome was not found to be significant. A second outcome, stroke, was reported in both the paper and the record, but the results differed in both direction and magnitude. A third outcome, myocardial infarction, was reported slightly differently, but neither odds ratio was found to be statistically significant.

Otherwise, the discrepancies were small, mostly involved the number analyzed, and did not affect the results. Full details are given in Table 3; discrepancies are indicated by bold/italic text.

Table 3. Results

\begin{tabular}{|c|c|c|c|c|c|c|c|c|}
\hline $\begin{array}{l}\text { Study Year } \\
\text { PMID } \\
\text { Region }^{\star \star}\end{array}$ & Outcome & Int (n-3 FA) & Control & $\begin{array}{l}\text { Flup } \\
\text { Time }\end{array}$ & $\begin{array}{l}\text { Int } n / N, \% \text { or } \\
\mathrm{N} \text { per arm for } \\
\text { continuous } \\
\text { outcomes }\end{array}$ & $\begin{array}{l}\text { Ctrl } \mathrm{n} / \mathrm{N}, \% \text { or } \\
\mathrm{N} \text { per arm for } \\
\text { continuous } \\
\text { outcomes }\end{array}$ & Effect Size & $\begin{array}{l}\text { Reported } \\
\text { P value }\end{array}$ \\
\hline \multicolumn{9}{|l|}{$\begin{array}{l}\text { Marine oil } \\
\text { vs. Placebo }\end{array}$} \\
\hline $\begin{array}{l}\text { Nodari } 2011 \\
21844082 \\
\text { Italy }\end{array}$ & $\begin{array}{l}\text { arrhythmia_A } \\
\text { Fib } \\
\text { (recurrence of } \\
\text { AFib) }\end{array}$ & $\begin{array}{l}\text { EPA+DHA } \\
(0.850-0.88 \\
2 \text { g/d } \\
\text { (marine oil)) }\end{array}$ & Placebo & $1 \mathrm{y}$ & $15 / 100,15 \%$ & $25 / 99,25 \%$ & $\begin{array}{l}\text { OR 0.52 } \\
(0.26,1.06)^{a}\end{array}$ & NR \\
\hline $\begin{array}{l}\text { NCT011982 } \\
75 \text { (Nodari } \\
2011 \\
21844082 \text { ) }\end{array}$ & $\begin{array}{l}\text { arrhythmia_A } \\
\text { Fib (no Atrial } \\
\text { Fibrillation } \\
\text { recurrence } \\
\text { at 1-year } \\
\text { followup)* }\end{array}$ & $\begin{array}{l}\text { EPA+DHA } \\
(0.850-0.882 \\
2 \mathrm{~g} / \mathrm{d} \\
(\text { Omacor }))\end{array}$ & Placebo & $1 \mathrm{y}$ & $61 / 100,61 \%$ & $34 / 9934 \%$ & $\begin{array}{l}\text { OR 0.441 } \\
(0.292, \\
0.666) \\
\text { These } \\
\text { results are } \\
\text { not in the } \\
\text { paper }\end{array}$ & $p<0.05$ \\
\hline $\begin{array}{l}\text { Maki } 2013 \\
23998969 \\
\text { US }\end{array}$ & $\begin{array}{l}\text { lipid_LDL } \\
\text { cholesterol }\end{array}$ & $\begin{array}{l}\text { EPA+DHA } \\
\text { (4 g/d total } \\
\text { oil -free fatty } \\
\text { acid oil) } \\
\end{array}$ & Placebo & $1.5 \mathrm{mo}$ & 207 & 211 & $\begin{array}{l}-0.5(-4.1 \\
3.1)(-6 \%)\end{array}$ & $p<0.0001$ \\
\hline $\begin{array}{l}\text { NCT014083 } \\
\text { O3 (Maki } \\
2013 \\
23998969 \\
\text { US) } \\
\end{array}$ & $\begin{array}{l}\text { lipid_LDL } \\
\text { cholesterol }\end{array}$ & $\begin{array}{l}\text { EPA+DHA } \\
\text { (4 g/d } \\
\text { Epanova) }\end{array}$ & Placebo & $1.5 \mathrm{mo}$ & 204 & 210 & $-6 \%$ & $p<0.0001$ \\
\hline
\end{tabular}




\begin{tabular}{|c|c|c|c|c|c|c|c|c|}
\hline $\begin{array}{l}\text { Study Year } \\
\text { PMID } \\
\text { Region** }\end{array}$ & Outcome & Int (n-3 FA) & Control & $\begin{array}{l}\text { Flup } \\
\text { Time }\end{array}$ & $\begin{array}{l}\text { Int } \mathrm{n} / \mathrm{N}, \% \text { or } \\
\mathrm{N} \text { per arm for } \\
\text { continuous } \\
\text { outcomes }\end{array}$ & $\begin{array}{l}\text { Ctrl } \mathrm{n} / \mathrm{N}, \% \text { or } \\
\mathrm{N} \text { per arm for } \\
\text { continuous } \\
\text { outcomes }\end{array}$ & Effect Size & $\begin{array}{l}\text { Reported } \\
\text { P value }\end{array}$ \\
\hline $\begin{array}{l}\text { Maki } 2013 \\
23998969 \\
\text { US }\end{array}$ & $\begin{array}{l}\text { lipid_LDL } \\
\text { cholesterol }\end{array}$ & $\begin{array}{l}\text { EPA+DHA } \\
(4 \mathrm{~g} / \mathrm{d} \text { total } \\
\text { oil -free fatty } \\
\text { acid oil) }\end{array}$ & $\begin{array}{l}2 \mathrm{~g} / \mathrm{d} \text { total } \\
\text { oil } \\
\text { (free fatty } \\
\text { acid oil) } \\
\text { [nd] }\end{array}$ & $1.5 \mathrm{mo}$ & 207 & 209 & $\begin{array}{l}-3.7(-7.3 \\
-0.1)(3 \%)\end{array}$ & \\
\hline $\begin{array}{l}\text { NCT014083 } \\
03 \text { (Maki } \\
2013 \\
23998969 \\
\text { US) } \\
\end{array}$ & $\begin{array}{l}\text { lipid_LDL } \\
\text { cholesterol }\end{array}$ & $\begin{array}{l}\text { EPA+DHA } \\
\text { (4 g/d } \\
\text { Epanova) }\end{array}$ & $\begin{array}{l}\text { EPA/DHA( } \\
\text { (2 g/d total } \\
\text { oil } \\
\text { (Epanova) }\end{array}$ & $1.5 \mathrm{mo}$ & 204 & 209 & $-3.05 \%$ & \\
\hline $\begin{array}{l}\text { Maki } 2013 \\
23998969 \\
\text { US }\end{array}$ & $\begin{array}{l}\text { lipid_LDL } \\
\text { cholesterol }\end{array}$ & $\begin{array}{l}\text { EPA+DHA } 2 \\
\text { g/d free fatty } \\
\text { acid oil) }\end{array}$ & Placebo & $1.5 \mathrm{mo}$ & 209 & 211 & $-3 \%$ & $p<0.05$ \\
\hline $\begin{array}{l}\text { NCT014083 } \\
03 \text { (Maki } \\
2013 \\
\text { 23998969 } \\
\text { US) }\end{array}$ & lipid_LDL & $\begin{array}{l}\text { EPA+DHA } \\
\text { (4 g/d } \\
\text { Epanova) }\end{array}$ & Placebo & $1.5 \mathrm{mo}$ & 209 & 210 & $-2.95 \%$ & $p<0.05$ \\
\hline $\begin{array}{l}\text { Kastelein } \\
2014 \\
24528690 \\
\text { Europe }\end{array}$ & lipid_Tg & $\begin{array}{l}\text { EPA+DHA } \\
\text { (EPA: } 2.20 \\
\text { g/d, DHA: } \\
0.80 \mathrm{~g} / \mathrm{d})\end{array}$ & Placebo & $12 \mathrm{wk}$ & 99 & 98 & $\begin{array}{l}-173.1 \\
(-250.3 \\
-95.8)\end{array}$ & $p<0.001$ \\
\hline $\begin{array}{l}\text { NCT012425 } \\
27 \\
\text { (Kastelein } \\
2014 \\
24528690 \text { ) }\end{array}$ & lipid_Tg & $\begin{array}{l}\text { EPA+DHA } \\
\text { (Epanova } \\
4 \mathrm{~g} / \mathrm{d} \text { ) }\end{array}$ & Placebo & $12 \mathrm{wk}$ & 95 & 98 & $\begin{array}{l}-26.6 \% \\
\text { (Matches \% } \\
\text { change in } \\
\text { paper) }\end{array}$ & $p<0.001$ \\
\hline $\begin{array}{l}\text { Kastelein } \\
2014 \\
24528690 \\
\text { Europe }\end{array}$ & lipid_Tg & $\begin{array}{l}\text { EPA+DHA } \\
\text { (EPA: } 1.65 \\
\text { g/d, DHA: } \\
0.60 \mathrm{~g} / \mathrm{d} \text { ) }\end{array}$ & Placebo & $12 \mathrm{wk}$ & 97 & 98 & $\begin{array}{l}-156.3 \\
(-238.8 \\
-73.8)\end{array}$ & $p<0.01$ \\
\hline $\begin{array}{l}\text { NCT012425 } \\
27 \\
\text { (Kastelein } \\
2014 \\
24528690 \text { ) } \\
\end{array}$ & lipid_Tg & $\begin{array}{l}\text { EPA+DHA } \\
\text { (Epanova } \\
\text { 3g) }\end{array}$ & Placebo & $12 \mathrm{wk}$ & 94 & 98 & $\begin{array}{l}-21.2 \% \\
\text { (Matches \% } \\
\text { change in } \\
\text { paper) }\end{array}$ & $p<0.01$ \\
\hline $\begin{array}{l}\text { Kastelein } \\
2014 \\
24528690 \\
\text { Europe }\end{array}$ & lipid_Tg & $\begin{array}{l}\text { EPA+DHA } \\
\text { (EPA: } 1.10 \\
\text { g/d, DHA: } \\
0.40 \mathrm{~g} / \mathrm{d} \text { ) }\end{array}$ & Placebo & $12 \mathrm{wk}$ & 99 & 98 & $\begin{array}{l}-156.4 \\
(-238.1 \\
-74.6)\end{array}$ & $p<0.01$ \\
\hline $\begin{array}{l}\text { NCT012425 } \\
27 \\
\text { (Kastelein } \\
2014 \\
24528690 \text { ) }\end{array}$ & lipid_Tg & $\begin{array}{l}\text { EPA+DHA } \\
\text { (Epanova } \\
2 \mathrm{~g} \text { ) }\end{array}$ & Placebo & $12 \mathrm{wk}$ & 95 & 98 & $\begin{array}{l}-21.68 \% \\
\text { (Matches \% } \\
\text { change in } \\
\text { paper) }\end{array}$ & $p<0.01$ \\
\hline $\begin{array}{l}\text { NCT007819 } \\
50 \\
\text { (Rodriguez- } \\
\text { Leyva 2013 } \\
\text { 24126178) }\end{array}$ & $\begin{array}{l}\text { MACE (All- } \\
\text { cause } \\
\text { Mortality, } \\
\text { Cardiovascul } \\
\text { ar Mortality, } \\
\text { Stroke, and } \\
\text { Myocardial } \\
\text { Infarctions) }\end{array}$ & $\begin{array}{l}\text { ALA } \\
\text { (flaxseed) }\end{array}$ & $\begin{array}{l}\text { Placebo } \\
\text { (wheat } \\
\text { and wheat } \\
\text { bran) }\end{array}$ & $1 y$ & $5 / 58(8.6 \%)$ & $4 / 52(7.7 \%)$ & $\begin{array}{l}\text { OR } 1.13 \\
(0.29,4.46) \\
\text { This } \\
\text { outcome is } \\
\text { not in the } \\
\text { paper }\end{array}$ & NS \\
\hline
\end{tabular}




\begin{tabular}{|c|c|c|c|c|c|c|c|c|}
\hline $\begin{array}{l}\text { Study Year } \\
\text { PMID } \\
\text { Region }^{\star \star}\end{array}$ & Outcome & $\operatorname{lnt}(n-3 F A)$ & Control & $\begin{array}{l}\text { Flup } \\
\text { Time }\end{array}$ & $\begin{array}{l}\text { Int } \mathrm{n} / \mathrm{N}, \% \text { or } \\
\mathrm{N} \text { per arm for } \\
\text { continuous } \\
\text { outcomes }\end{array}$ & $\begin{array}{l}\text { Ctrl } \mathrm{n} / \mathrm{N}, \% \text { or } \\
\mathrm{N} \text { per arm for } \\
\text { continuous } \\
\text { outcomes }\end{array}$ & Effect Size & $\begin{array}{l}\text { Reported } \\
\text { P value }\end{array}$ \\
\hline $\begin{array}{l}\text { NCT007819 } \\
50 \\
\text { (Rodriguez- } \\
\text { Leyva 2013 } \\
24126178 \text { ) }\end{array}$ & $\begin{array}{l}\text { death_all } \\
\text { cause }\end{array}$ & $\begin{array}{l}\text { ALA } \\
\text { (flaxseed) }\end{array}$ & $\begin{array}{l}\text { Placebo } \\
\text { (wheat } \\
\text { and wheat } \\
\text { bran) }\end{array}$ & $1 y$ & $1 / 581.7 \%$ & $0 / 52,0 \%$ & $\begin{array}{l}\text { OR } 2.73 \\
(0.11,68.64) \\
\text { This } \\
\text { outcome is } \\
\text { not in the } \\
\text { paper }\end{array}$ & NS \\
\hline $\begin{array}{l}\text { Rodriguez- } \\
\text { Leyva } 2013 \\
24126178\end{array}$ & cardiac_Ml & $\begin{array}{l}\text { ALA (5.9 g/d } \\
\text { flaxseed) }\end{array}$ & Placebo & $1 y$ & $2 / 583.4 \%$ & $4 / 527.7 \%$ & $\begin{array}{l}\text { OR } 0.43 \\
(0.08,2.44) \\
\text { Slight } \\
\text { difference }\end{array}$ & NS \\
\hline $\begin{array}{l}\text { NCT007819 } \\
50 \\
\text { (Rodriguez- } \\
\text { Leyva 2013 } \\
24126178 \text { ) } \\
\end{array}$ & cardiac_Ml & $\begin{array}{l}\text { ALA } \\
\text { (flaxseed) }\end{array}$ & $\begin{array}{l}\text { Placebo } \\
\text { (wheat } \\
\text { and wheat } \\
\text { bran) }\end{array}$ & $1 y$ & $1 / 581.7 \%$ & $3 / 525.8 \%$ & $\begin{array}{l}\text { OR } 0.29 \\
(0.03,2.84) \\
\text { Slight } \\
\text { difference }\end{array}$ & NS \\
\hline $\begin{array}{l}\text { Rodriguez- } \\
\text { Leyva } 2013 \\
24126178\end{array}$ & $\begin{array}{l}\text { cerebro_Strok } \\
\text { e }\end{array}$ & $\begin{array}{l}\text { ALA (5.9 g/d } \\
\text { flaxseed) }\end{array}$ & Placebo & $1 y$ & $1 / 581.7 \%$ & $2 / 523.8 \%$ & $\begin{array}{l}\text { OR } 0.44 \\
(0.04,4.98) \\
\text { Different in } \\
\text { direction } \\
\text { and } \\
\text { magnitude }\end{array}$ & NS \\
\hline $\begin{array}{l}\text { NCT007819 } \\
50 \\
\text { (Rodriguez- } \\
\text { Leyva 2013 } \\
24126178 \text { ) }\end{array}$ & $\begin{array}{l}\text { cerebro_Strok } \\
\text { e }\end{array}$ & $\begin{array}{l}\text { ALA } \\
\text { (flaxseed) }\end{array}$ & $\begin{array}{l}\text { Placebo } \\
\text { (wheat } \\
\text { and wheat } \\
\text { bran) }\end{array}$ & $1 \mathrm{y}$ & $3 / 585.2 \%$ & $1 / 521.9 \%$ & $\begin{array}{l}\text { OR } 2.78 \\
(0.28,27.61) \\
\text { Different in } \\
\text { direction } \\
\text { and } \\
\text { magnitude }\end{array}$ & NS \\
\hline $\begin{array}{l}\text { Rodriguez- } \\
\text { Leyva } 2013 \\
24126178 \\
\end{array}$ & bp_DBP & $\begin{array}{l}\text { ALA (5.9 g/d } \\
\text { flaxseed) }\end{array}$ & Placebo & $1 y$ & 45 & 41 & $\begin{array}{l}-2.1(-7.2 \\
3.0)\end{array}$ & \\
\hline $\begin{array}{l}\text { NCT007819 } \\
50 \\
\text { (Rodriguez- } \\
\text { Leyva 2013 } \\
\text { 24126178) }\end{array}$ & bp_DBP & $\begin{array}{l}\text { ALA } \\
\text { (flaxseed) }\end{array}$ & $\begin{array}{l}\text { Placebo } \\
\text { (wheat } \\
\text { and wheat } \\
\text { bran) }\end{array}$ & $1 \mathrm{y}$ & 45 & 41 & $\begin{array}{l}71.8(1.7) \text { vs. } \\
78.5(1.5) \\
\text { Final values; } \\
\text { no baselines } \\
\text { given. } \\
\text { Matches } \\
\text { paper. }\end{array}$ & \\
\hline $\begin{array}{l}\text { Rodriguez- } \\
\text { Leyva } 2013 \\
24126178 \\
\end{array}$ & bp_SBP & $\begin{array}{l}\text { ALA (5.9 g/d } \\
\text { flaxseed) }\end{array}$ & Placebo & $1 y$ & 45 & 41 & $\begin{array}{l}-7.3(-15.4 \\
0.80)\end{array}$ & \\
\hline $\begin{array}{l}\text { NCT007819 } \\
50 \\
\text { (Rodriguez- } \\
\text { Leyva 2013 } \\
24126178 \text { ) }\end{array}$ & bp_SBP & $\begin{array}{l}\text { ALA } \\
\text { (flaxseed) }\end{array}$ & $\begin{array}{l}\text { Placebo } \\
\text { (wheat } \\
\text { and wheat } \\
\text { bran) }\end{array}$ & $1 \mathrm{y}$ & 45 & 41 & $\begin{array}{l}136.2(3.8) \\
\text { vs.145.6 } \\
(3.4) \\
\text { Final values; } \\
\text { no baselines } \\
\text { given. } \\
\text { Matches } \\
\text { paper. }\end{array}$ & \\
\hline
\end{tabular}

* discrepancies are indicated by bold italic text; **for each shading the first row (with no NCT number) is the published study from the original report, the second row is the corresponding registry record; $A F i b=$ atrial fibrillation, $L D L=$ low-density lipoprotein, $\mathrm{HDL}=$ high-density lipoprotein, $\mathrm{MI}=$ myocardial infarction, $\mathrm{DBP}=$ diastolic blood pressure, $\mathrm{SBP}=$ systolic blood pressure. 


\section{Adverse Events}

Both the papers and the records with results mentioned adverse events. The reported adverse events matched the paper in all but one study. Nausea, which is thought to be an adverse effect of Omega-3 supplementation, was reported in the record for the Rodriguez-Leyva study but was not reported in the paper. ${ }^{27}$ Full details are given in Appendix E, Table E-6.

\section{Risk of Bias}

We evaluated the risk of bias for all studies identified in both the report and the records. In general, there was insufficient evidence to make judgements on specific risk of bias items.

Where the evidence was sufficient, the records and reports agreed most of the time. Details are in Appendix E, Tables E-7 and E88. We did not find any new information that would change our initial risk of bias or strength or evidence assessments.

\section{Relevant Studies Identified via Registry Searches and Not Found in Original Review}

Of the 69 studies in 76 records identified through registry searches that met full criteria for inclusion in the original report, 43 studies (in 49 records) were not found in the original review (42 randomized controlled trials and 1 Observational Study); 28 (57\%) records in ClinicalTrials.gov and 21 records in ICTRP (43\%). The completion status of studies described in the 49 records are as follows; completed $n=23$, ongoing $n=10$ and unknown status $n=13$. The study enrollment estimates for studies completed as of December 31, 2016 account for a projected 20088 participants. An additional 145275 participants were estimated to enroll in the remaining studies (ongoing and unknown status). The mean start date of the studies included in the report was about 5 years earlier than the mean start date of the studies not in the report (Figure 2). In addition, many of the studies not in the report were not completed at the time of the search, which explains why they did not have publications or results.

Reviewing the evidence map for the original report, we identified publications for seven of these studies, which did not meet inclusion/exclusion criteria for the original report. Details about these studies are in Table 4. A single record yielded a new publication emanating from a study included in our original report. This new manuscript was published in the intervening time since the last update of the report search. Relevant results from this study were already identified in another publication and included in the report, the results in this newly identified manuscript were added to the report, but did not change the direction or magnitude of the results for those outcomes.

Table 4. Overall description of studies in the registry but not the report

\begin{tabular}{|l|l|l|l|l|l|l|l|}
\hline $\begin{array}{l}\text { Study Identifier } \\
\text { Country/ies } \\
\text { Study Name }\end{array}$ & Registry & Population & $\begin{array}{l}\text { Date } \\
\text { (start/end) }\end{array}$ & $\begin{array}{l}\text { N } \\
\text { total* }\end{array}$ & $\begin{array}{l}\text { Study design: } \\
\text { Intervention }\end{array}$ & $\begin{array}{l}\text { Intermediate } \\
\text { Outcomes }\end{array}$ & $\begin{array}{l}\text { Clinical } \\
\text { Outcomes }\end{array}$ \\
\hline $\begin{array}{l}\text { CTRI/2012/08/002856, } \\
\text { India }\end{array}$ & $\begin{array}{l}\text { ICTRP } \\
\text { (Clinical } \\
\text { Trial } \\
\text { Registry of } \\
\text { India) }\end{array}$ & Healthy/obese & $2012-?$ & 60 & $\begin{array}{l}\text { RCT: EPA 180 mg + } \\
\text { DHA 120 mg } \\
\text { capsules vs. EPA 180 } \\
\text { mg + DHA 120 mg } \\
\text { capsules capsules + } \\
\text { probiotic capsules vs. } \\
\text { probiotic capsules vs. } \\
\text { placebo }\end{array}$ & $\begin{array}{l}\text { BP/Lipids } \\
\text { Cardiac } \\
\text { event/arrhythmia } \\
\text { RCT: Fish oil } \\
\text { capsules (1.8g/d of } \\
\text { EPA+DHA) }\end{array}$ & \\
\hline NCT00232219, Australia & CT.gov & CVD, existing & $2003-2013$ & 200 & $\begin{array}{l}\text { Arrhythmia } \\
\text { event }\end{array}$ \\
\hline
\end{tabular}




\begin{tabular}{|c|c|c|c|c|c|c|c|}
\hline $\begin{array}{l}\text { Study Identifier } \\
\text { Country/ies } \\
\text { Study Name }\end{array}$ & Registry & Population & $\begin{array}{l}\text { Date } \\
\text { (start/end) }\end{array}$ & $\begin{array}{l}\mathrm{N} \\
\text { total* }^{*}\end{array}$ & $\begin{array}{l}\text { Study design: } \\
\text { Intervention }\end{array}$ & $\begin{array}{l}\text { Intermediate } \\
\text { Outcomes }\end{array}$ & $\begin{array}{l}\text { Clinical } \\
\text { Outcomes }\end{array}$ \\
\hline $\begin{array}{l}\text { NCT02183285, no } \\
\text { location listed }\end{array}$ & CT.gov & Healthy & $2003-2004$ & 203 & $\begin{array}{l}\text { RCT: Multivitamin, } \\
\text { Multimineral + } \\
\text { Omega-3 Fatty Acids } \\
\text { vs Multivitamin, } \\
\text { Multimineral without } \\
\text { Omega-3 Fatty Acids } \\
\text { vs placebo }\end{array}$ & BP/Lipids & AEs \\
\hline $\begin{array}{l}\text { NCT01350973, no } \\
\text { location listed }\end{array}$ & CT.gov & Dyslipidemia & $2009-2010$ & 611 & $\begin{array}{l}\text { RCT: Omacor } 2 \mathrm{~g} \text {, } \\
\text { capsules, orally, once } \\
\text { daily for up to } 12 \\
\text { weeks vs. Omacor } 2 \\
\mathrm{~g}, \text { capsules, orally, } \\
\text { twice daily for up to } \\
12 \text { weeks vs. EPA-E, } \\
0.6 \mathrm{~g} \text {, orally, three- } \\
\text { times daily for up to } \\
12 \text { weeks. }\end{array}$ & BP/Lipids & AEs \\
\hline $\begin{array}{l}\text { NCT01350999, no } \\
\text { location listed }\end{array}$ & CT.gov & Dyslipidemia & $2009-2011$ & 503 & $\begin{array}{l}\text { RCT: Omacor } 2 \mathrm{~g} \text {, } \\
\text { capsules, orally, once } \\
\text { daily for up to } 52 \\
\text { weeks vs. Omacor } 2 \\
\mathrm{~g}, \text { capsules, orally, } \\
\text { twice daily for up to } \\
52 \text { weeks vs. EPA-E, } \\
0.6 \mathrm{~g} \text {, orally, three- } \\
\text { times daily for up to } \\
52 \text { weeks. }\end{array}$ & $\begin{array}{l}\text { BP/Lipids, } \\
\text { HTN }\end{array}$ & \\
\hline NCT01048502, US & CT.gov & CVD, existing & $2010-2011$ & 100 & $\begin{array}{l}\text { RCT: Tricor } 145 \\
\text { mg/day vs. Lovaza } \\
900 \text { mg/day vs. } \\
\text { Lovaza } 3600 \text { mg/day } \\
\text { vs placebo }\end{array}$ & BP/Lipids & \\
\hline NCT02239198, US & CT.gov & Healthy & $2007-2008$ & 150 & $\begin{array}{l}\text { RCT: Complete } \\
\text { nutrition bar with } \\
\text { omega-3 fatty acids } \\
\text { vs. Nutrition bar } \\
\text { without omega-3 fatty } \\
\text { acids vs. Nutrition bar } \\
\text { without added } \\
\text { minerals and vitamins }\end{array}$ & BP/Lipids & \\
\hline NCT00135226, UK & CT.gov & DM & $2005-2016$ & 15480 & $\begin{array}{l}\text { RCT: Aspirin } 100 \\
\text { mg/day + Omega-3- } \\
\text { Ethyl Esters 1g/day } \\
\text { vs. Aspirin } 100 \\
\text { mg/day + Placebo vs. } \\
\text { Placebo + Omega-3- } \\
\text { Ethyl Esters 1g/day } \\
\text { vs. Placebo }\end{array}$ & & $\begin{array}{l}\text { Cardiac events, } \\
\text { stroke/TIA }\end{array}$ \\
\hline NCT01810003, Canada & CT.gov & CVD, existing & $2013-2016$ & 170 & $\begin{array}{l}\text { RCT: DHA 3g/day (10 } \\
\text { wks) vs. EPA 3g/day } \\
\text { (10 wks) vs. placebo }\end{array}$ & BP/Lipids & \\
\hline NCT02210767, US & CT.gov & Healthy & $2014-2016$ & 50 & $\begin{array}{l}\text { RCT: } 2 \text { oz } \\
\text { walnuts/day (ALA) vs. } \\
\text { fatty acids not from } \\
\text { walnuts vs. low ALA } \\
\text { diet }\end{array}$ & BP/Lipids & \\
\hline NCT02285166, Japan & CT.gov & Dyslipidemia & $2014-2019$ & 14000 & $\begin{array}{l}\text { RCT: Lotriga } 2- \\
\text { 4g/day vs. standard } \\
\text { antihyperlipidemic } \\
\text { therapy }\end{array}$ & $\begin{array}{l}\text { BP/Lipids, } \\
\text { HTN }\end{array}$ & $\begin{array}{l}\text { Cardiac events, } \\
\text { stroke/TIA, } \\
\text { arrhythmia, } \\
\text { PDV, death }\end{array}$ \\
\hline NCT01841944, Norway & CT.gov & CVD, existing & $2012-2019$ & 1400 & $\begin{array}{l}\text { RCT: Pikasol }(1.8 \mathrm{~g} \\
\text { EPA+DHA)/day vs. } \\
\text { placebo }\end{array}$ & & $\begin{array}{l}\text { Cardiac events, } \\
\text { stroke/TIA, } \\
\text { arrhythmia, } \\
\text { death }\end{array}$ \\
\hline
\end{tabular}




\begin{tabular}{|c|c|c|c|c|c|c|c|}
\hline $\begin{array}{l}\text { Study Identifier } \\
\text { Country/ies } \\
\text { Study Name }\end{array}$ & Registry & Population & $\begin{array}{l}\text { Date } \\
\text { (start/end) }\end{array}$ & $\begin{array}{l}\mathrm{N} \\
\text { total* }\end{array}$ & $\begin{array}{l}\text { Study design: } \\
\text { Intervention }\end{array}$ & $\begin{array}{l}\text { Intermediate } \\
\text { Outcomes }\end{array}$ & $\begin{array}{l}\text { Clinical } \\
\text { Outcomes }\end{array}$ \\
\hline NCT01320228, Denmark & CT.gov & Healthy & $2011-2012$ & 69 & $\begin{array}{l}\text { RCT: Alli ( } 60 \mathrm{mg} \text { t.i.d) } \\
+5 \mathrm{~g} \text { flaxseed fibers } \\
\text { and } 1200 \mathrm{mg} \text { Ca from } \\
\text { Capolac vs. Alli ( } 60 \\
\text { mg t.i.d) }+5 \mathrm{~g} \\
\text { flaxseed fibers vs. Alli } \\
(60 \mathrm{mg} \text { t.i.d) + } 1200 \\
\text { mg Ca from Capolac } \\
\text { vs. Alli }(60 \mathrm{mg} \text { t.i.d) + } \\
\text { placebo }\end{array}$ & BP/Lipids & \\
\hline $\begin{array}{l}\text { NCT02294526, no } \\
\text { location listed }\end{array}$ & CT.gov & DM & $2012-2013$ & 35 & $\begin{array}{l}\text { RCT: Sardine }(100 \mathrm{~g} \\
\text { per day, } 5 \text { days a } \\
\text { week) diet vs no } \\
\text { sardine diet }\end{array}$ & BP/Lipids & \\
\hline $\begin{array}{l}\text { NCT01492361, US, } \\
\text { Australia, Canada, India, } \\
\text { Netherlands, New } \\
\text { Zealand, Poland, } \\
\text { Romania, Russian } \\
\text { Federation, South Africa, } \\
\text { Ukraine }\end{array}$ & CT.gov & CVD, existing & $2011-2017$ & 8000 & $\begin{array}{l}\text { RCT: VASCEPA } \\
\text { (icosapent ethyl) vs. } \\
\text { placebo }\end{array}$ & BP/Lipids & $\begin{array}{l}\text { Cardiac events, } \\
\text { stroke/TIA, } \\
\text { arrhythmia, } \\
\text { death }\end{array}$ \\
\hline $\begin{array}{l}\text { NCT02104817, US, } \\
\text { Argentina, Australia, } \\
\text { Brazil, Canada, Czech } \\
\text { Republic, Denmark, } \\
\text { Estonia, Hungary, Italy, } \\
\text { Japan, Korea, Latvia, } \\
\text { Lithuania, Mexico, } \\
\text { Netherlands, New } \\
\text { Zealand, Poland, } \\
\text { Romania, Russian } \\
\text { Federation, South Africa, } \\
\text { Taiwan, Ukraine, United } \\
\text { Kingdom }\end{array}$ & CT.gov & $\begin{array}{l}\text { Other (mixed) } \\
\text { CVD high risk }\end{array}$ & $2014-2019$ & 13000 & $\begin{array}{l}\text { RCT: Epanova + } \\
\text { statin daily vs. } \\
\text { placebo + statin daily }\end{array}$ & & $\begin{array}{l}\text { Cardiac events, } \\
\text { stroke/TIA, } \\
\text { arrhythmia, } \\
\text { death }\end{array}$ \\
\hline $\begin{array}{l}\text { NCT02243969, } \\
\text { Netherlands }\end{array}$ & CT.gov & Mixed & $2014-2015$ & 72 & $\begin{array}{l}\text { RCT: Flaxseed oil } \\
\text { (ALA) 10g/day (12 } \\
\text { wks) vs. placebo }\end{array}$ & BP/Lipids & \\
\hline NCT01169259, US & CT.gov & Mixed & $2010-2017$ & 25874 & $\begin{array}{l}\text { RCT: Vitamin D3 } \\
2000 \text { IU/day + } \\
\text { Omacor, } 1 \\
\text { capsule/day vs. } \\
\text { Vitamin D3 } 2000 \\
\text { IU/day + placebo vs. } \\
\text { placebo + Omacor, } 1 \\
\text { capsule/day vs. } \\
\text { placebo }\end{array}$ & & Cardiac events \\
\hline NCT02271230, US & CT.gov & CVD, existing & $2014-2020$ & 25875 & $\begin{array}{l}\text { RCT: Vitamin D } 2000 \\
\text { IU/day vs. EPA/DHA } \\
\text { 1g/day vs. placebo }\end{array}$ & & Cardiac events \\
\hline NCT01785004, US & CT.gov & Healthy & $2012-2015$ & 600 & $\begin{array}{l}\text { RCT: Vitamin D3 } \\
2000 \text { IU/day + } \\
\text { Omacor, } 1 \\
\text { capsule/day vs. } \\
\text { Vitamin D3 } 2000 \\
\text { IU/day + placebo vs. } \\
\text { placebo + Omacor, } 1 \\
\text { capsule/day vs. } \\
\text { placebo }\end{array}$ & BP/Lipids & \\
\hline
\end{tabular}




\begin{tabular}{|c|c|c|c|c|c|c|c|}
\hline $\begin{array}{l}\text { Study Identifier } \\
\text { Countrylies } \\
\text { Study Name }\end{array}$ & Registry & Population & $\begin{array}{l}\text { Date } \\
\text { (start/end) }\end{array}$ & $\begin{array}{l}\mathrm{N} \\
\text { total* }\end{array}$ & $\begin{array}{l}\text { Study design: } \\
\text { Intervention }\end{array}$ & $\begin{array}{l}\text { Intermediate } \\
\text { Outcomes }\end{array}$ & $\begin{array}{l}\text { Clinical } \\
\text { Outcomes }\end{array}$ \\
\hline NCT01653678, US & CT.gov & HTN & 2011-2017 & 25875 & $\begin{array}{l}\text { RCT: Vitamin D3 } \\
2000 \text { IU/day + } \\
\text { Omacor, } 1 \\
\text { capsule/day vs. } \\
\text { Vitamin D3 } 2000 \\
\text { IU/day + placebo vs. } \\
\text { placebo + Omacor, } 1 \\
\text { capsule/day vs. } \\
\text { placebo }\end{array}$ & $\begin{array}{l}\text { BP/Lipids, } \\
\text { HTN }\end{array}$ & \\
\hline NCT02178410, US & CT.gov & CVD, existing & $2012-2017$ & 25875 & $\begin{array}{l}\text { RCT: Vitamin D3 } \\
2000 \text { IU/day + } \\
\text { Omacor, } 1 \\
\text { capsule/day vs. } \\
\text { Vitamin D3 } 2000 \\
\text { IU/day + placebo vs. } \\
\text { placebo + Omacor, } 1 \\
\text { capsule/day vs. } \\
\text { placebo }\end{array}$ & & $\begin{array}{l}\text { Cardiac events, } \\
\text { arrhythmia, } \\
\text { death }\end{array}$ \\
\hline NCT02155816, US & CT.gov & Healthy & $2014-2014$ & 68 & $\begin{array}{l}\text { RCT: Omega } 3 \\
(1000 \mathrm{mg} / \text { day) for } 8 \\
\text { wks vs. Omega } 7 \\
\text { ( } 210 \mathrm{mg} / \text { day) and } \\
\text { Omega } 3 \\
\text { (1000mg/day) for } 8 \\
\text { wks vs. placebo }\end{array}$ & BP/Lipids & \\
\hline $\begin{array}{l}\text { NCT00967733, no } \\
\text { location listed }\end{array}$ & CT.gov & CVD, existing & $2009-2009$ & 130 & $\begin{array}{l}\text { RCT: Flaxseed oil } \\
\text { (ALA) } 2-4 \text { g/day + } \\
\text { olive oil cooking vs. } \\
\text { Olive oil pill } 1 \text { g/day + } \\
\text { olive oil cooking vs. } \\
\text { Flaxseed oil (ALA) } 2- \\
4 \text { g/day + sunflower } \\
\text { oil cooking vs. Olive } \\
\text { oil pill } 1 \text { g/day + } \\
\text { sunflower oil cooking } \\
\end{array}$ & BP/Lipids & \\
\hline NCT00422266, India & CT.gov & Dyslipidemia & $2006-2007$ & 178 & $\begin{array}{l}\text { RCT: Not explicitly } \\
\text { described }\end{array}$ & BP/Lipids & \\
\hline NCT01224249, Denmark & CT.gov & Healthy & $2010-2011$ & 102 & $\begin{array}{l}\text { Obs: Fish and } \\
\text { shellfish } 1000 \mathrm{~g} / \text { week } \\
\text { for six months vs. no } \\
\text { comparator }\end{array}$ & BP/Lipids & \\
\hline $\begin{array}{l}\text { ACTRN12607000278437, } \\
\text { Australia }\end{array}$ & ICTRP & Healthy & $2007-?$ & 400 & $\begin{array}{l}\text { RCT: DHA } 430 \\
\text { mg/EPA } 150 \text { mg QID } \\
\text { vs. olive oil }\end{array}$ & $\mathrm{BP}$ & \\
\hline $\begin{array}{l}\text { DRKS00006742, } \\
\text { Germany }\end{array}$ & ICTRP & HTN & $2015-2015$ & 100 & $\begin{array}{l}\text { RCT: Milk with DHA } \\
250 \text { mg/day (4 } \\
\text { weeks) vs. Milk with } \\
\text { beta-glucans } 3 g / d a y \\
\text { (4 weeks) vs. Milk } \\
\text { with anthocyanins } \\
320 \mathrm{mg} / \text { day (4 weeks) } \\
\text { vs. Milk with DHA } \\
250 \mathrm{mg}+\text { beta- } \\
\text { glucans } 3 g / d a y ~(4 \\
\text { weeks) vs. Milk with } \\
\text { DHA 250mg + } \\
\text { anthocyanins } \\
320 \mathrm{mg} / \text { day (4 weeks) }\end{array}$ & BP/Lipids & \\
\hline $\begin{array}{l}\text { JPRN-UMIN000011934, } \\
\text { Japan }\end{array}$ & ICTRP & CVD, existing & $2010-2013$ & 80 & $\begin{array}{l}\text { RCT: EPA 1800mg + } \\
\text { statin therapy/day (2 } \\
\text { yrs) vs. Ezetimibe } 10 \\
\text { mg + statin } \\
\text { therapy/day (2yrs) vs. } \\
\text { statin therapy (2yrs) }\end{array}$ & & $\begin{array}{l}\text { Cardiac events, } \\
\text { PVD, death }\end{array}$ \\
\hline
\end{tabular}




\begin{tabular}{|c|c|c|c|c|c|c|c|}
\hline $\begin{array}{l}\text { Study Identifier } \\
\text { Country/ies } \\
\text { Study Name }\end{array}$ & Registry & Population & $\begin{array}{l}\text { Date } \\
\text { (start/end) }\end{array}$ & $\begin{array}{l}\mathrm{N} \\
\text { total* }\end{array}$ & $\begin{array}{l}\text { Study design: } \\
\text { Intervention }\end{array}$ & $\begin{array}{l}\text { Intermediate } \\
\text { Outcomes }\end{array}$ & $\begin{array}{l}\text { Clinical } \\
\text { Outcomes }\end{array}$ \\
\hline $\begin{array}{l}\text { JPRN-UMIN000007956, } \\
\text { Japan }\end{array}$ & ICTRP & CVD, existing & 2012-? & 80 & $\begin{array}{l}\text { RCT: EPA } 1800 \\
\text { mg/day + statin } \\
\text { therapy vs. statin } \\
\text { therapy }\end{array}$ & BP/Lipids & \\
\hline ISRCTN16448451, UK & ICTRP & CVD, existing & $1998-2002$ & nd & $\begin{array}{l}\text { RCT: fish oil + normal } \\
\text { diet vs. normal diet }\end{array}$ & & Arrhythmia \\
\hline ISRCTN24439243, Spain & ICTRP & $\begin{array}{l}\text { Other (mixed) } \\
\text { CVD high risk }\end{array}$ & $2009-2011$ & 250 & $\begin{array}{l}\text { RCT: increased fish } \\
\text { consumption }+ \\
\text { normal diet vs. } \\
\text { normal diet }\end{array}$ & BP/Lipids & \\
\hline RBR-5668v4, Brazil & ICTRP & $\begin{array}{l}\text { Other (mixed) } \\
\text { CVD high risk }\end{array}$ & $2011-2013$ & 87 & $\begin{array}{l}\text { RCT: Omega-3 } \\
\text { 900my/day + dietary } \\
\text { guidance vs. dietary } \\
\text { guidance }\end{array}$ & BP/Lipids & \\
\hline $\begin{array}{l}\text { IRCT2013080514273N1, } \\
\text { no location listed }\end{array}$ & ICTRP & CVD, existing & $2013-2013$ & 60 & RCT: & BP/Lipids & \\
\hline $\begin{array}{l}\text { JPRN-UMIN000006416, } \\
\text { Japan }\end{array}$ & ICTRP & CVD, existing & 2009-? & 100 & $\begin{array}{l}\text { RCT: Aspirin100 } \\
\text { mg/day vs. EPA ethyl } \\
\text { ester 1800mg/day + } \\
\text { Aspirin100mg/day }\end{array}$ & BP/Lipids & \\
\hline $\begin{array}{l}\text { JPRN-UMIN000007266, } \\
\text { Japan }\end{array}$ & ICTRP & CVD, existing & 2012-? & 200 & $\begin{array}{l}\text { RCT: EPA vs. } \\
\text { antiplatelet + statins }\end{array}$ & & $\begin{array}{l}\text { Cardiac events, } \\
\text { stroke/TIA, PVD, } \\
\text { death }\end{array}$ \\
\hline $\begin{array}{l}\text { JPRN-UMIN000012069, } \\
\text { Japan }\end{array}$ & ICTRP & CVD, existing & $2013-2019$ & 3200 & $\begin{array}{l}\text { RCT: EPA } 1800 \\
\text { mg/day + statin } \\
\text { therapy vs. statin } \\
\text { therapy }\end{array}$ & & $\begin{array}{l}\text { Cardiac events, } \\
\text { stroke/TIA, PVD, } \\
\text { death }\end{array}$ \\
\hline $\begin{array}{l}\text { JPRN-UMIN000016723, } \\
\text { Japan }\end{array}$ & ICTRP & CVD, existing & 2010-? & 200 & $\begin{array}{l}\text { RCT: pitavastatin } 2 \\
\text { mg/day + EPA } 1800 \\
\text { mg/day vs. } \\
\text { pitavastatin } 2 \text { mg/day }\end{array}$ & & $\begin{array}{l}\text { Cardiac events, } \\
\text { stroke/TIA }\end{array}$ \\
\hline $\begin{array}{l}\text { JPRN-UMIN000018056, } \\
\text { Japan }\end{array}$ & ICTRP & Dyslipidemia & 2015-? & 40 & $\begin{array}{l}\text { RCT: DHA+EPA } \\
2 \mathrm{~g} / \text { day ( } 4 \text { wks) at } 4 \\
\text { wks, triglycerides } \\
>150 \text { mg/dl, dose } \\
\text { increased to } 4 \mathrm{mg} / \text { day } \\
\text { ( } 8 \text { weeks); } \\
\text { triglycerides } \\
<150 \mathrm{mg} / \mathrm{dl} \text {, does } \\
\text { maintained at } \\
2 \text { mg/day vs. } \\
\text { observation }\end{array}$ & BP/Lipids & Cardiac events \\
\hline $\begin{array}{l}\text { JPRN-UMIN000004024, } \\
\text { Japan }\end{array}$ & ICTRP & Dyslipidemia & 2010-? & 100 & $\begin{array}{l}\text { RCT: EPA (no other } \\
\text { details reported) }\end{array}$ & BP/Lipids & \\
\hline $\begin{array}{l}\text { JPRN-UMIN000012852, } \\
\text { Japan }\end{array}$ & ICTRP & CVD, existing & 2014-? & 100 & $\begin{array}{l}\text { RCT: EPA } 1800 \\
\text { mg/day + statin } \\
\text { therapy vs. statin } \\
\text { therapy }\end{array}$ & & $\begin{array}{l}\text { Cardiac events, } \\
\text { stroke/TIA, PVD, } \\
\text { death }\end{array}$ \\
\hline $\begin{array}{l}\text { EUCTR2006-006863-22- } \\
\text { GB, UK }\end{array}$ & ICTRP & CVD, existing & 2007-? & 100 & $\begin{array}{l}\text { RCT: Cardiozen } 500 \\
\text { mg vs. placebo (no } \\
\text { other information) }\end{array}$ & & arrhythmia \\
\hline $\begin{array}{l}\text { EUCTR2005-001354-25- } \\
\text { GB, UK }\end{array}$ & ICTRP & CVD, existing & 2005-? & 150 & $\begin{array}{l}\text { RCT: Omacor vs. } \\
\text { placebo (no other } \\
\text { information) }\end{array}$ & & Arrhythmia \\
\hline $\begin{array}{l}\text { EUCTR2005-004969-41- } \\
\text { IT, Italy }\end{array}$ & ICTRP & CVD, existing & 2006-? & 266 & $\begin{array}{l}\text { RCT: SEACOR } \\
\text { 1000MG vs. placebo } \\
\text { (no other information) }\end{array}$ & & Arrhythmia \\
\hline NCT02103517, China & CT.gov & Healthy & $2014-2015$ & 400 & $\begin{array}{l}\text { RCT: Omega-3 FA } \\
4 \mathrm{gm} / \text { day ( } 3 \text { mos) vs. } \\
\text { placebo }\end{array}$ & BP/Lipids & \\
\hline $\begin{array}{l}\text { JPRN-UMIN000003947, } \\
\text { Japan }\end{array}$ & ICTRP & CVD, existing & 2010-? & 200 & $\begin{array}{l}\text { RCT: EPA } 1800 \\
\text { mg/day + statin } \\
\text { therapy vs. statin } \\
\text { therapy }\end{array}$ & & $\begin{array}{l}\text { Cardiac events, } \\
\text { PVD, Death }\end{array}$ \\
\hline
\end{tabular}




\begin{tabular}{|c|c|c|c|c|c|c|c|}
\hline $\begin{array}{l}\text { Study Identifier } \\
\text { Countrylies } \\
\text { Study Name }\end{array}$ & Registry & Population & $\begin{array}{l}\text { Date } \\
\text { (start/end) }\end{array}$ & $\begin{array}{l}\mathrm{N} \\
\text { total* }\end{array}$ & $\begin{array}{l}\text { Study design: } \\
\text { Intervention }\end{array}$ & $\begin{array}{l}\text { Intermediate } \\
\text { Outcomes }\end{array}$ & $\begin{array}{l}\text { Clinical } \\
\text { Outcomes }\end{array}$ \\
\hline $\begin{array}{l}\text { JPRN-UMIN000012825, } \\
\text { Japan }\end{array}$ & ICTRP & CVD, existing & $2014-2019$ & 180 & $\begin{array}{l}\text { RCT: Statin vs. Statin } \\
+ \text { EPA vs. Statin + } \\
\text { EPA + DHA }\end{array}$ & BP/Lipids & \\
\hline NCT01723345, Iran & CT.gov & CVD, existing & $2012-2013$ & 90 & $\begin{array}{l}\text { RCT: EPA } 400 \mathrm{mg}+ \\
\text { DHA } 200 \mathrm{mg} 12 \mathrm{~h} \\
\text { prior to } \mathrm{PCl} \text { vs } \\
\text { standard treatment }\end{array}$ & & Cardiac events \\
\hline $\begin{array}{l}\text { NCT01422317 } \\
\text { Norway } \\
\text { OFAMI }\end{array}$ & CT.gov & CVD, existing & 1995-2002 & 300 & $\begin{array}{l}\text { RCT: Fish oil } \\
\text { (EPA+DHA) } 3.464 \mathrm{~g} / \mathrm{d} \\
\text { vs. Placebo }\end{array}$ & Lipids & Cardiac event \\
\hline
\end{tabular}

RCT: randomized controlled trial; XO: crossover tiral; CT.gov: ClinicalTrials.gov; ICTRP: International Clinical Trials Registry Platform; CVD: cardiovascular disease; NRCS: non-randomized comparative study; TIA: transient ischemic attack; PVD: peripheral vascular disease; BP: blood pressure; EPA: eicosapentaenoic acid; DHA: docosahexaenoic acid; ALA: alphalinolenic acid; PUFA: polyunsaturated fatty acids; SDA: stearidonic acid 
Figure 2. Timing of studies

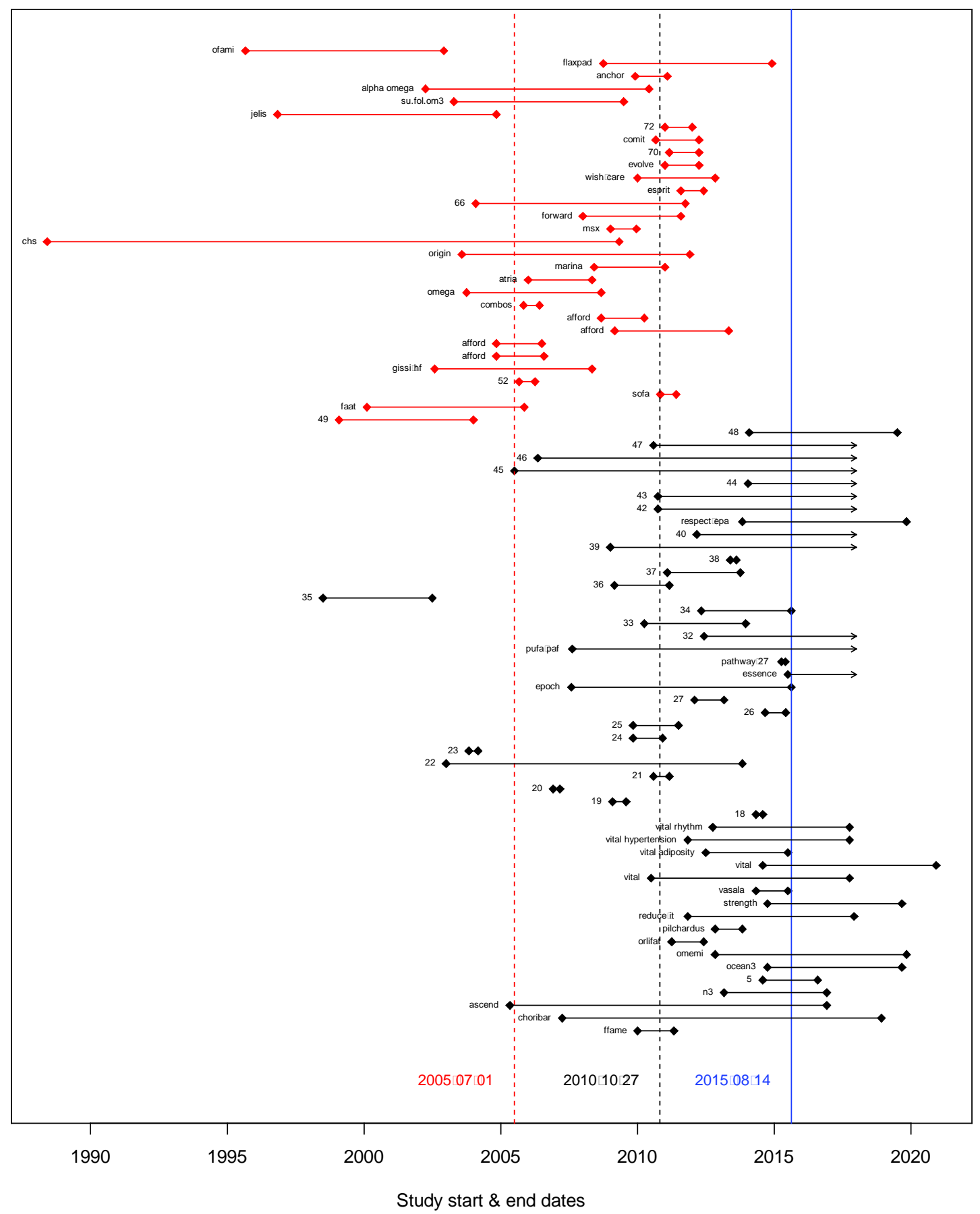

Red lines indicate studies in the review; black lines indicate studies not in the review. The red dashed line is the mean start date for studies in the review. The black dashed line is the mean start date for studies not in the review. The blue solid line is the date of the search. Lines with arrows indicate records that did not give an estimated completion date. In two cases, no start date was given, so we used the date of entry into the registry. 


\section{Studies Included in the Original Review, with No Registry Record}

The original report's 98 studies included 61 randomized controlled trials in 82 articles and 37 longitudinal observational studies in 65 articles. Of these, we were unable to find a registry record for 72 studies (73\%), including 36 randomized controlled trials (59\%) and 36 longitudinal observational studies (97\%). This may be due to the fact that many of the studies in the report were completed before the requirement to register in ClinicalTrials.gov. 


\section{Discussion}

\section{Summary of Findings}

\section{Studies Identified via Registry Searches and Found in Original Review}

Overall, 69 studies in 76 records identified through registry searches met full criteria for inclusion in the original report. Of these, 26 studies (in 27 registry records) were included in the original report (25 RCTs, 1 observational Study); 22 of these were found in ClinicalTrials.gov, 3 were found in ICTRP, and 1 was identified in both registries. Of the 26 studies in both sources, only 4 studies (in 4 records) included eligible results in the registry records. In general, the agreement between the registry record and the published paper was good when the information was given in both. A fifth record of a factorial study reported results, but no comparison between the n-3 FA and no n-3 FAs was reported in the record.

\section{Relevant Studies Identified via Registry Searches and Not Found in Original Review}

Of the 69 studies in 76 records identified through registry searches that met full criteria for inclusion in the original report, 43 studies (in 49 records) were not found in the original review (42 randomized controlled trials and 1 Observational Study); 28 (57\%) records in

ClinicalTrials.gov and 21 records in ICTRP (43\%). The completion status of studies described in the 49 records are as follows; completed $n=23$, ongoing $n=10$ and unknown status $n=13$. The study enrollment estimates for studies completed as of December 31, 2016 account for a projected 20,088 participants. An additional 145,275 participants were estimated to enroll in the remaining studies (ongoing and unknown status).

Reviewing the evidence map for the original report, we identified publications for seven of these studies, which did not meet inclusion/exclusion criteria for the original report. A single record yielded a new publication emanating from a study included in our original report. This new manuscript was published in the intervening time since the last update of the report search. Relevant results from this study were already identified in another publication and included in the report, the results in this newly identified manuscript were added to the report, but did not change the direction or magnitude of the results for those outcomes.

\section{Studies Included in the Original Review, with No Registry Record}

The original report's 98 studies included 61 randomized controlled trials in 82 articles and 37 longitudinal observational studies in 65 articles. Of these, we were unable to find a registry record for 72 studies (73\%), including 36 randomized controlled trials (59\%) and 36 longitudinal observational studies (97\%). 


\section{Process Limitations}

Our study demonstrated that the EPC systematic review process was amenable to adaptions required for searching, abstracting, and analyzing registry search yields. We used a very broad search and screened out a large number of records, requiring more staff time than is spent on registry searching for typical EPC systematic reviews. More precise searching may reduce associated study costs and sensitivity of the search. In general, we found that registry records were easy to screen and extract - often easier than the resulting publications. Study design and interventions information was readily identifiable and in almost all cases matched that of the papers. However, the patient-level information (baselines and outcomes) was limited in scope and detail. The addition of individual patient data to these records could be very valuable.

Despite the relative ease of conducting registry searches in our study, the searches yielded no new information that would change our initial risk of bias or strength or evidence assessments. When available, study design, baselines, adverse events reporting, and results reported in the registry and publication typically aligned. Data identified via registry searches generally provided insufficient evidence to make judgments on specific risk of bias items. It was also difficult to draw any conclusions about publication bias based on our analyses.

Study outcomes information had highest number of discrepancies, potentially indication selective reporting bias. However, because many of these studies are relatively recent, it is also possible that information on these outcomes has not been published yet, but will be, indicating time lag, but not publication, bias

\section{Challenges to Incorporating Clinical Trial Registry Records into the Systematic Review Process}

\section{Statistical Plans}

We found no reporting of statistical design for any of the studies in our report. We reviewed Clinicaltrials.gov guidance to better understand this consistent pattern of non-reporting. Based on ClinicalTrials.gov guidance, ${ }^{31}$ statistical analysis plans (i.e., describing the analytical principles and statistical techniques to be employed in order to address the primary and secondary objectives, as specified in the study protocol or plan) and plans for missing data (i.e., to address situations where variables are reported as missing, unavailable, "non-reported," uninterpretable, or considered missing because of data inconsistency or out-of-range results) are requested only for observational studies registered as patient registries. ${ }^{31}$ Our report included very few observational studies, and thus, statistical design reporting could not be assessed.

\section{Results}

In September 2008, ClinicalTrials.gov added a results database to the registry record. Nevertheless, submission of results to a trial registry is not always required of investigators/authors. The Food and Drug Administration Amendments Act of 2007 (FDAAA; U.S. Public Law 110-85, Title VIII), mandates the posting of summary results data for certain trials in ClinicalTrials.gov. ${ }^{32}$ Of import, ICJME has stated that more detailed descriptions of trial 
results "beyond those included in ClinicalTrials.gov" may be considered prior publication, at the discretion of journal editors. Further, ICMJE does not require reporting of results for interventional clinical studies trials. ${ }^{32}$

Thus, a lack of results in a trial registry can be attributed to changes in the reporting requirements over time or a function of why investigators chose to register their study in the first place. Utilizing registry records to assess information bias pivot on both sponsor/investigator compliance with registration and sponsor/investigators perception of registry purpose, thus interpreting these omissions may unintentionally aggregate bias with inconsistent interpretation of the purpose, role and scope of ClinicalTrials.gov.

\section{Next Steps}

One way in which conducting a registry search is of value to a systematic review project is in identifying ongoing research, as well as gaps in knowledge, and facilitating prioritization of future research to reduce redundancy. Several of the studies not found in the original review but identified through registry searches were unfinished or in progress at the time of the search, these studies should be taken in to account when evaluating the state of the literature and calling for future research. 


\section{References}

1. Duval S, Tweedie R. Trim and fill: A simple funnel-plot-based method of testing and adjusting for publication bias in metaanalysis. Biometrics. 2000 Jun;56(2):45563. PMID: 10877304.

2. Egger M, Davey Smith G, Schneider M, et al. Bias in meta-analysis detected by a simple, graphical test. BMJ. 1997 Sep 13;315(7109):629-34. PMID: 9310563.

3. Harbord RM, Egger M, Sterne JA. A modified test for small-study effects in meta-analyses of controlled trials with binary endpoints. Stat Med. 2006 Oct 30;25(20):3443-57. doi: 10.1002/sim.2380. PMID: 16345038.

4. Rucker G, Carpenter JR, Schwarzer G. Detecting and adjusting for small-study effects in meta-analysis. Biom J. 2011 Mar;53(2):351-68. doi: 10.1002/bimj.201000151. PMID: 21374698.

5. Copas J, Shi JQ. Meta-analysis, funnel plots and sensitivity analysis. Biostatistics. 2000 Sep;1(3):247-62. doi:

10.1093/biostatistics/1.3.247. PMID: 12933507.

6. Copas JB, Shi JQ. A sensitivity analysis for publication bias in systematic reviews. Stat Methods Med Res. 2001 Aug;10(4):251-65. PMID: 11491412.

7. Hedges LV, Vevea JL. Estimating effect size under publication bias: small sample properties and robustness of a random effects selection model. Journal of Educational and Behavioral Statistics. 1996;21(4):299-332.

8. Laine C, Horton R, DeAngelis C, et al. Clinical trial registration: looking back and moving ahead. N Z Med J. 2007;120(1256):U2586. PMID: 17589554.

9. Wood AJ. Progress and deficiencies in the registration of clinical trials. N Engl J Med. 2009 Feb 19;360(8):824-30. doi: 10.1056/NEJMsr0806582. PMID: 19228628.
10. Zarin DA, Tse T, Sheehan J. The proposed rule for U.S. clinical trial registration and results submission. N Engl J Med. 2015 Jan 8;372(2):174-80. doi:

10.1056/NEJMsr1414226. PMID: 25539444.

11. Chan AW, Hrobjartsson A, Haahr MT, et al. Empirical evidence for selective reporting of outcomes in randomized trials: comparison of protocols to published articles. JAMA. 2004 May 26;291(20):2457-65. doi: 10.1001/jama.291.20.2457. PMID: 15161896.

12. Roest AM, de Jonge P, Williams CD, et al. Reporting Bias in Clinical Trials Investigating the Efficacy of SecondGeneration Antidepressants in the Treatment of Anxiety Disorders: A Report of 2 Metaanalyses. JAMA Psychiatry. 2015 May 1;72(5):500-10. doi: 10.1001/jamapsychiatry.2015.15. PMID: 25806940.

13. Vedula SS, Bero L, Scherer RW, et al. Outcome reporting in industry-sponsored trials of gabapentin for off-label use. N Engl J Med. 2009 Nov 12;361(20):1963-71. doi: 10.1056/NEJMsa0906126. PMID: 19907043.

14. Vedula SS, Li T, Dickersin K. Differences in reporting of analyses in internal company documents versus published trial reports: comparisons in industry-sponsored trials in off-label uses of gabapentin. PLoS Med. 2013;10(1):e1001378. doi: 10.1371/journal.pmed.1001378. PMID: 23382656.

15. Anderson ML, Chiswell K, Peterson ED, et al. Compliance with results reporting at ClinicalTrials.gov. N Engl J Med. 2015 Mar 12;372(11):1031-9. doi: 10.1056/NEJMsa1409364. PMID: 25760355.

16. Viergever RF, Ghersi D. The quality of registration of clinical trials. PLoS One. 2011;6(2):e14701. 
17. Viergever RF, Karam G, Reis A, et al. The quality of registration of clinical trials: still a problem. PLoS One. 2014;9(1):e84727. doi: 10.1371/journal.pone.0084727. PMID: 24427293.

18. Saunders C, Scott RE. Applying change management metaphors to a national eHealth strategy. Stud Health Technol Inform. 2014;206:62-9. PMID: 25365672.

19. Balk E, Chung M, Lichtenstein A, et al. Effects of omega-3 fatty acids on cardiovascular risk factors and intermediate markers of cardiovascular disease. Evid Rep Technol Assess (Summ). 2004 Mar(93):1-6. PMID: 15133887.

20. E B. Protocol: Omega 3 Fatty Acids and Cardiovascular Disease - Update. Rockville, MD: Agency for Healthcare Research and Quality 2015.

http://www.effectivehealthcare.ahrq.gov/ind ex.cfm/search-for-guides-reviews-andreports/?pageaction=displayproduct\&produc tid $=2060$

21. Wang C, Chung M, Lichtenstein A, et al. Effects of omega-3 fatty acids on cardiovascular disease. Evid Rep Technol Assess (Summ). 2004 Mar(94):1-8. PMID: 15133888.

22. Glanville JM, Duffy S, McCool R, et al. Searching ClinicalTrials.gov and the International Clinical Trials Registry Platform to inform systematic reviews: what are the optimal search approaches? J Med Libr Assoc. 2014 Jul;102(3):177-83. doi: 10.3163/1536-5050.102.3.007. PMID: 25031558.

23. Jakobsen NK, Jensen LS, Kayser L. Collaborative efforts are needed to ensure proper knowledge dissemination of telemedicine projects. Dan Med J. 2014 Sep;61(9):A4896. PMID: 25186538.

24. Bosch J, Gerstein HC, Dagenais GR, et al. n-3 fatty acids and cardiovascular outcomes in patients with dysglycemia. N Engl J Med. 2012 Jul 26;367(4):309-18. doi: 10.1056/NEJMoa1203859. PMID: 22686415.
25. Damsgaard CT, Frokiaer H, Andersen AD, et al. Fish oil in combination with high or low intakes of linoleic acid lowers plasma triacylglycerols but does not affect other cardiovascular risk markers in healthy men. J Nutr. 2008 Jun;138(6):1061-6. PMID: 18492834.

26. Leyva DR, Zahradka P, Ramjiawan B, et al. The effect of dietary flaxseed on improving symptoms of cardiovascular disease in patients with peripheral artery disease: rationale and design of the FLAX-PAD randomized controlled trial. Contemp Clin Trials. 2011 Sep;32(5):724-30. doi: 10.1016/j.cct.2011.05.005. PMID: 21616170.

27. Rodriguez-Leyva D, Weighell W, Edel AL, et al. Potent antihypertensive action of dietary flaxseed in hypertensive patients. Hypertension. 2013 Dec;62(6):1081-9. doi: 10.1161/hypertensionaha.113.02094. PMID: 24126178.

28. Kastelein JJ, Maki KC, Susekov A, et al. Omega-3 free fatty acids for the treatment of severe hypertriglyceridemia: the EpanoVa fOr Lowering Very high triglyceridEs (EVOLVE) trial. J Clin Lipidol. 2014 JanFeb;8(1):94-106. doi: 10.1016/j.jacl.2013.10.003. PMID: 24528690.

29. Maki KC, Orloff DG, Nicholls SJ, et al. A highly bioavailable omega-3 free fatty acid formulation improves the cardiovascular risk profile in high-risk, statin-treated patients with residual hypertriglyceridemia (the ESPRIT trial). Clin Ther. 2013 Sep;35(9):1400-11.e1-3. doi: 10.1016/j.clinthera.2013.07.420. PMID: 23998969.

30. Nodari S, Triggiani M, Campia U, et al. n-3 polyunsaturated fatty acids in the prevention of atrial fibrillation recurrences after electrical cardioversion: a prospective, randomized study. Circulation. 2011 Sep 6;124(10):1100-6. doi: 10.1161/circulationaha.111.022194. PMID: 21844082. 
31. Sakai T, Izumi M, Kumagai K, et al. Effects of a Foot Pump on the Incidence of Deep Vein Thrombosis After Total Knee Arthroplasty in Patients Given Edoxaban: A Randomized Controlled Study. Medicine (Baltimore). 2016 Jan;95(1):e2247. doi: 10.1097/md.0000000000002247. PMID: 26735531.
32. Fuji T, Fujita S, Kawai YJ, et al. Efficacy and safety of edoxaban versus enoxaparin for the prevention of venous thromboembolism following total hip arthroplasty: STARS J-V. Thromb J. 2015;13:27. doi: 10.1186/s12959-015-0057x. PMID: 25963358. 


\section{Appendix A. Search Strategies}

Registry Searches

Databases: ClinicalTrials.gov 8/14/2015 (5084 unique citations)

Search 1: Omega 3 OR Omega3 OR Omega-3 OR Fish OR n-3 OR Docosahexaenoic OR DHA OR Eicosapentaenoic OR EPA OR ALA OR alpha linolenic OR alphalinolenic OR alphalinolenic OR fatty acids OR fatty acid OR PUFA OR SDA OR stearidonic

Search 2: Ropufa OR MaxEPA OR Omacor OR Efamed OR ResQ OR Epagis OR Almarin OR Coromega OR Lovaza OR Vascepa OR icosapent ethyl OR mediterranean diet

Search 3: salmon OR mackerel OR herring OR tuna OR halibut OR seaweed OR anchovy OR anchovies OR sardine OR sardines OR cod liver oil OR codliver oil OR marine oil

Search 4: walnut OR walnuts OR butternut OR butternuts OR soybean OR soybeans OR pumpkin seed OR pumpkin seeds OR flax OR flaxseed OR flax seed OR linseed OR rape seed OR rapeseed OR canola OR soy OR soybean OR walnut OR mustard seed OR perilla OR shiso

Databases: ICTRP 8/14/2015 (3468 unique citations)

Omega 3 OR Omega3 OR Omega-3 OR Fish OR n-3 OR Docosahexaenoic OR DHA OR Eicosapentaenoic OR EPA OR ALA OR alpha linolenic OR alphalinolenic OR alpha-linolenic OR fatty acids OR fatty acid OR PUFA OR SDA OR stearidonic OR Ropufa OR MaxEPA OR Omacor OR Efamed OR ResQ OR Epagis OR Almarin OR Coromega OR Lovaza OR Vascepa OR icosapent ethyl OR mediterranean diet OR salmon OR mackerel OR herring OR tuna OR halibut OR seaweed OR anchovy OR anchovies OR sardine OR sardines OR cod liver oil OR codliver oil OR marine oil OR walnut OR walnuts OR butternut OR butternuts OR soybean OR soybeans OR pumpkin seed OR pumpkin seeds OR flax OR flaxseed OR flax seed OR linseed OR rape seed OR rapeseed OR canola OR soy OR soybean OR walnut OR mustard seed OR perilla OR shiso

\section{Original Report}

Omega 3 CVD update 2015-update search (Search 1 for updated outcomes, limited to 20022015)

Databases: MEDLINE, CAB Abstracts, Cochrane through Ovid 6/8/2015

\begin{tabular}{|c|c|c|}
\hline \# & Search & \multirow{7}{*}{ 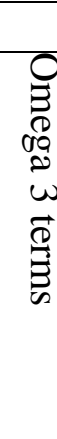 } \\
\hline 1. & exp fatty acids, omega-3/ & \\
\hline 2. & $\begin{array}{l}\text { ((omega-3 or omega } 3 \text { or omega3) and fatty acid\$).mp. [mp=ti, ab, ot, nm, hw, } \\
\text { kf, px, rx, ui, tx, kw, ct, sh, bt, id, cc] }\end{array}$ & \\
\hline 3. & fatty acids, essential/ & \\
\hline 4. & linolenic acids/ & \\
\hline 5. & exp fish oils/ & \\
\hline 6. & $\begin{array}{l}\text { ((n } 3 \text { or n3 or n-3) and (oil\$ or pufa or fatty acid\$ or omega 3)).mp. [mp=ti, ab, } \\
\text { ot, nm, hw, kf, px, rx, ui, tx, kw, ct, sh, bt, id, cc] }\end{array}$ & \\
\hline
\end{tabular}




\begin{tabular}{|c|c|c|}
\hline \# & Search & \\
\hline 7. & Docosahexaenoic Acids/ & \\
\hline 8. & $\begin{array}{l}\text { docosahexa?noic.mp. [mp=ti, ab, ot, nm, hw, kf, px, rx, ui, tx, kw, ct, sh, bt, id, } \\
\text { cc] or docosapenta?noic.mp. }\end{array}$ & \\
\hline 9. & Eicosapentaenoic Acid/ & \\
\hline 10. & $\begin{array}{l}\text { eicosapenta?noic.mp. [mp=ti, ab, ot, nm, hw, kf, px, rx, ui, tx, kw, ct, sh, bt, id, } \\
\text { cc] }\end{array}$ & \\
\hline 11. & $\begin{array}{l}\text { icosapent?enoic.mp. [mp=ti, ab, ot, nm, hw, kf, px, rx, ui, tx, kw, ct, sh, bt, id, } \\
\text { cc] }\end{array}$ & \\
\hline 12. & $\begin{array}{l}\text { (alpha linolenic or alphalinolenic or alpha-linolenic).mp. [mp=ti, ab, ot, nm, } \\
\text { hw, kf, px, rx, ui, tx, kw, ct, sh, bt, id, cc] }\end{array}$ & \\
\hline 13. & $\begin{array}{l}\text { (linolenate or cervonic or timnodonic or stearidonic).mp. [mp=ti, ab, ot, nm, } \\
\text { hw, kf, px, rx, ui, tx, kw, ct, sh, bt, id, cc] }\end{array}$ & \\
\hline 14. & $\begin{array}{l}\text { menhaden oil\$.mp. [mp=ti, ab, ot, nm, hw, kf, px, rx, ui, tx, kw, ct, sh, bt, id, } \\
\text { cc] }\end{array}$ & \\
\hline 15. & $\begin{array}{l}\text { ((flax or flaxseed or flax seed or linseed or rape seed or rapeseed or canola or } \\
\text { soy or soybean or walnut or mustard seed or perilla or shiso) adj2 oil\$).mp. } \\
{[\mathrm{mp}=\mathrm{ti}, \mathrm{ab}, \mathrm{ot}, \mathrm{nm}, \mathrm{hw}, \mathrm{kf}, \mathrm{px}, \mathrm{rx}, \mathrm{ui}, \mathrm{tx}, \mathrm{kw}, \mathrm{ct}, \mathrm{sh}, \mathrm{bt}, \mathrm{id}, \mathrm{cc}]}\end{array}$ & \\
\hline 16. & $\begin{array}{l}\text { (walnut\$ or butternut\$ or soybean\$ or pumpkin seed\$).mp. [mp=ti, ab, ot, nm, } \\
\text { hw, kf, px, rx, ui, tx, kw, ct, sh, bt, id, cc] }\end{array}$ & \\
\hline 17. & $\begin{array}{l}\text { (fish adj2 oil\$).mp. [mp=ti, ab, ot, nm, hw, kf, px, rx, ui, tx, kw, ct, sh, bt, id, } \\
\text { cc] }\end{array}$ & \\
\hline 18. & $\begin{array}{l}\text { (cod liver oil\$ or codliver oil\$ or marine oil\$ or marine fat\$).mp. [mp=ti, ab, } \\
\text { ot, nm, hw, kf, px, rx, ui, tx, kw, ct, sh, bt, id, cc] }\end{array}$ & \\
\hline 19. & $\begin{array}{l}\text { (salmon or mackerel or herring or tuna or halibut or seaweed or anchov\$ or } \\
\text { sardine\$).mp. [mp=ti, ab, ot, nm, hw, kf, px, rx, ui, tx, kw, ct, sh, bt, id, cc] }\end{array}$ & \\
\hline 20. & $\begin{array}{l}\text { (Ropufa or MaxEPA or Omacor or Efamed or ResQ or Epagis or Almarin or } \\
\text { Coromega or Lovaza or Vascepa or icosapent ethyl).mp. [mp=ti, ab, ot, nm, } \\
\text { hw, kf, px, rx, ui, tx, kw, ct, sh, bt, id, cc] }\end{array}$ & \\
\hline 21. & $\begin{array}{l}\text { (fish consumption or fish intake or (fish adj2 diet\$)).mp. [mp=ti, ab, ot, nm, } \\
\text { hw, kf, px, rx, ui, tx, kw, ct, sh, bt, id, cc] }\end{array}$ & \\
\hline 22. & $\begin{array}{l}\text { (mediterranean adj diet\$).mp. [mp=ti, ab, ot, nm, hw, kf, px, rx, ui, tx, kw, ct, } \\
\text { sh, bt, id, cc] }\end{array}$ & \\
\hline 23. & $\begin{array}{l}\text { ((red blood cell or phospholipid or plasma fatty acid or plasma or phospholipid } \\
\text { or triacylglycerol or cholesteryl or ester or adipos\$ or fatty acid or erythrocyte } \\
\text { or ghost or platelet or granulocyte or neutrophil or mononuclear or LDL or } \\
\text { HDL) and (DHA or docosahexa?noic or docosapenta?noic or EPA or } \\
\text { eicosapenta?noic or SDA or linolenic or stearidonic or omega)).mp. [mp=ti, ab, } \\
\text { ot, nm, hw, kf, px, rx, ui, tx, kw, ct, sh, bt, id, cc] }\end{array}$ & 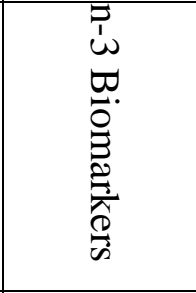 \\
\hline 24. & or/1-23 & n-3 \\
\hline 25. & exp cardiovascular diseases/ & $\underset{2}{2} \approx$ \\
\hline 26. & atherosclero\$.mp. [mp=ti, ab, ot, nm, hw, kf, px, rx, ui, tx, kw, ct, sh, bt, id, cc] & 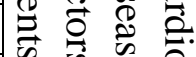 \\
\hline 27. & $\begin{array}{l}\text { Arteriosclero\$.mp. [mp=ti, ab, ot, nm, hw, kf, px, rx, ui, tx, kw, ct, sh, bt, id, } \\
\text { cc] }\end{array}$ & 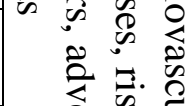 \\
\hline 28. & $\begin{array}{l}\text { cardioprotect\$.mp. [mp=ti, ab, ot, nm, hw, kf, px, rx, ui, tx, kw, ct, sh, bt, id, } \\
\text { cc] }\end{array}$ & 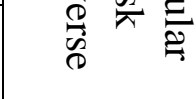 \\
\hline
\end{tabular}




\begin{tabular}{|c|c|c|}
\hline \# & Search & \\
\hline 29. & Coronary.mp. [mp=ti, ab, ot, nm, hw, kf, px, rx, ui, tx, kw, ct, sh, bt, id, cc] & \\
\hline 30. & $\begin{array}{l}\text { heart disease\$.mp. [mp=ti, ab, ot, nm, hw, kf, px, rx, ui, tx, kw, ct, sh, bt, id, } \\
\text { cc] }\end{array}$ & \\
\hline 31. & $\begin{array}{l}\text { Myocardial infarct\$.mp. [mp=ti, ab, ot, nm, hw, kf, px, rx, ui, tx, kw, ct, sh, bt, } \\
\text { id, cc] }\end{array}$ & \\
\hline 32. & exp Cerebrovascular Accident/ & \\
\hline 33. & stroke.mp. [mp=ti, ab, ot, nm, hw, kf, px, rx, ui, tx, kw, ct, sh, bt, id, cc] & \\
\hline 34. & $\begin{array}{l}\text { (Transient Ischemic Attack or TIA).mp. [mp=ti, ab, ot, nm, hw, kf, px, rx, ui, } \\
\text { tx, kw, ct, sh, bt, id, cc] }\end{array}$ & \\
\hline 35. & exp lipids/ & \\
\hline 36. & lipid\$.mp. [mp=ti, ab, ot, nm, hw, kf, px, rx, ui, tx, kw, ct, sh, bt, id, cc] & \\
\hline 37. & exp cholesterol/ & \\
\hline 38. & cholesterol.mp. [mp=ti, ab, ot, nm, hw, kf, px, rx, ui, tx, kw, ct, sh, bt, id, cc] & \\
\hline 39. & exp Lipoproteins, LDL/ & \\
\hline 40. & exp Lipoproteins, HDL/ & \\
\hline 41. & exp triglycerides/ & \\
\hline 42. & triglycerides.mp. [mp=ti, ab, ot, nm, hw, kf, px, rx, ui, tx, kw, ct, sh, bt, id, cc] & \\
\hline 43. & exp Hyperlipidemias/ & \\
\hline 44. & $\begin{array}{l}\text { hypertriglyceridem\$.mp. [mp=ti, ab, ot, nm, hw, kf, px, rx, ui, tx, kw, ct, sh, bt, } \\
\text { id, cc ] }\end{array}$ & \\
\hline 45. & $\begin{array}{l}\text { hyperlipidemia\$.mp. [mp=ti, ab, ot, nm, hw, kf, px, rx, ui, tx, kw, ct, sh, bt, id, } \\
\text { cc] }\end{array}$ & \\
\hline 46. & exp dyslipidemias/ & \\
\hline 47. & $\begin{array}{l}\text { dyslipidemia\$.mp. [mp=ti, ab, ot, nm, hw, kf, px, rx, ui, tx, kw, ct, sh, bt, id, } \\
\text { cc] }\end{array}$ & \\
\hline 48. & exp blood pressure/ & \\
\hline 49. & $\begin{array}{l}\text { blood pressure.mp. [mp=ti, ab, ot, nm, hw, kf, px, rx, ui, tx, kw, ct, sh, bt, id, } \\
\text { cc] }\end{array}$ & \\
\hline 50. & $\begin{array}{l}\text { (diastol\$ or systol\$ or mean arterial).mp. [mp=ti, ab, ot, nm, hw, kf, px, rx, ui, } \\
\text { tx, kw, ct, sh, bt, id, cc] }\end{array}$ & \\
\hline 51. & exp hypertension/ & \\
\hline 52. & hypertension.mp. [mp=ti, ab, ot, nm, hw, kf, px, rx, ui, tx, kw, ct, sh, bt, id, cc] & \\
\hline 53. & exp Hemorrhage/ & \\
\hline 54. & hemorrhag\$.mp. [mp=ti, ab, ot, nm, hw, kf, px, rx, ui, tx, kw, ct, sh, bt, id, cc] & \\
\hline 55. & bleeding.mp. [mp=ti, ab, ot, nm, hw, kf, px, rx, ui, tx, kw, ct, sh, bt, id, cc] & \\
\hline 56. & or/25-55 & \\
\hline 57. & 24 and 56 & $\begin{array}{l}\mathrm{n}-3 \& \\
\text { CVD }\end{array}$ \\
\hline 58. & $\begin{array}{l}\text { (random\$ or rct\$).mp. [mp=ti, ab, ot, nm, hw, kf, px, rx, ui, tx, kw, ct, sh, bt, } \\
\text { id, cc] }\end{array}$ & 艺 \\
\hline 59. & exp randomized controlled trials/ & Dิ \\
\hline 60. & exp Randomized Controlled Trials as Topic/ & $\stackrel{n}{\sigma}$. \\
\hline 61. & exp random allocation/ & \\
\hline 62. & exp double-blind method/ & \\
\hline
\end{tabular}




\begin{tabular}{|c|c|c|}
\hline \# & Search & \\
\hline 63. & exp single-blind method/ & \\
\hline 64. & randomized controlled trial.pt. & \\
\hline 65. & clinical trial.mp. [mp=ti, ab, ot, nm, hw, kf, px, rx, ui, tx, kw, ct, sh, bt, id, cc] & \\
\hline 66. & $\begin{array}{l}\text { (clin\$ adj trial\$).mp. [mp=ti, ab, ot, nm, hw, kf, px, rx, ui, tx, kw, ct, sh, bt, id, } \\
\text { cc] }\end{array}$ & \\
\hline 67. & $\begin{array}{l}\text { ((singl\$ or doubl\$ or trebl\$ or tripl\$) adj (blind\$ or mask\$)).mp. [mp=ti, ab, ot, } \\
\text { nm, hw, kf, px, rx, ui, tx, kw, ct, sh, bt, id, cc] }\end{array}$ & \\
\hline 68. & exp placebos/ & \\
\hline 69. & placebo\$.mp. [mp=ti, ab, ot, nm, hw, kf, px, rx, ui, tx, kw, ct, sh, bt, id, cc] & \\
\hline 70 . & $\begin{array}{l}\text { randomly allocated.mp. [mp=ti, ab, ot, nm, hw, kf, px, rx, ui, tx, kw, ct, sh, bt, } \\
\text { id, cc] }\end{array}$ & \\
\hline 71. & $\begin{array}{l}\text { (allocated adj2 random\$).mp. [mp=ti, ab, ot, nm, hw, kf, px, rx, ui, tx, kw, ct, } \\
\text { sh, bt, id, cc] }\end{array}$ & \\
\hline 72. & $\begin{array}{l}\text { comparative study.mp. [mp=ti, ab, ot, nm, hw, kf, px, rx, ui, tx, kw, ct, sh, bt, } \\
\text { id, cc] }\end{array}$ & \\
\hline 73. & follow-up studies/ & \\
\hline 74. & $\begin{array}{l}\text { (follow up or followup).mp. [mp=ti, ab, ot, nm, hw, kf, px, rx, ui, tx, kw, ct, sh, } \\
\text { bt, id, cc] }\end{array}$ & \\
\hline 75. & exp case-control studies/ & \\
\hline 76. & $\begin{array}{l}\text { (case adj20 control).mp. [mp=ti, ab, ot, nm, hw, kf, px, rx, ui, tx, kw, ct, sh, bt, } \\
\text { id, cc] }\end{array}$ & \\
\hline 77. & exp longitudinal studies/ & \\
\hline 78. & longitudinal.mp. [mp=ti, ab, ot, nm, hw, kf, px, rx, ui, tx, kw, ct, sh, bt, id, cc] & \\
\hline 79. & exp cohort studies/ & \\
\hline 80. & cohort.mp. [mp=ti, ab, ot, nm, hw, kf, px, rx, ui, tx, kw, ct, sh, bt, id, cc] & \\
\hline 81. & exp prospective studies/ & \\
\hline 82. & exp evaluation studies/ & \\
\hline 83. & $\begin{array}{l}\text { (observational adj (study or studies)).mp. [mp=ti, ab, ot, nm, hw, kf, px, rx, ui, } \\
\text { tx, kw, ct, sh, bt, id, cc] }\end{array}$ & \\
\hline 84. & Cross-Sectional Studies/ & \\
\hline 85. & $\begin{array}{l}\text { (cross section\$ or cross-section\$).mp. [mp=ti, ab, ot, nm, hw, kf, px, rx, ui, tx, } \\
\mathrm{kw}, \mathrm{ct}, \mathrm{sh}, \mathrm{bt}, \mathrm{id}, \mathrm{cc}]\end{array}$ & \\
\hline 86. & $\begin{array}{l}\text { food frequency questionnaire\$.mp. [mp=ti, ab, ot, nm, hw, kf, px, rx, ui, tx, kw, } \\
\text { ct, sh, bt, id, cc] }\end{array}$ & \\
\hline 87. & or/58-86 & \\
\hline 88. & 57 and 87 & $\begin{array}{l}\mathrm{n}-3, \\
\text { CVD, } \\
\text { Designs }\end{array}$ \\
\hline 89. & $\begin{array}{l}\text { limit } 88 \text { to (addresses or autobiography or bibliography or biography or case } \\
\text { reports or comment or congresses or dictionary or directory or editorial or } \\
\text { festschrift or government publications or historical article or interview or } \\
\text { lectures or legal cases or legislation or letter or news or newspaper article or } \\
\text { patient education handout or periodical index) }\end{array}$ & $\begin{array}{l}\text { Not non- } \\
\text { studies }\end{array}$ \\
\hline 90. & 88 not 89 & \\
\hline
\end{tabular}




\begin{tabular}{|c|c|c|}
\hline \# & Search & \\
\hline 91. & limit 90 to english language & \multirow{2}{*}{ Limits } \\
\hline 92. & limit 91 to humans & \\
\hline 93. & (guidelines or practice guideline or meta analysis or systematic review).pt. & \multirow{4}{*}{ SRs, GLs } \\
\hline 94. & (systematic\$ adj3 review\$).tw. & \\
\hline 95. & 93 or 94 & \\
\hline 96. & 57 and 95 & \\
\hline 97. & limit 96 to $y r=" 2002-2015 "$ & Non-SRs \\
\hline 98. & 92 not 96 & \multirow{2}{*}{ SRs } \\
\hline 99. & limit 98 to $y r=" 2002-2015 "$ & \\
\hline
\end{tabular}


Omega 3 CVD update 2015-new outcomes 6/8/2015 (Only difference is new outcomes and publication dates)

\begin{tabular}{|c|c|}
\hline \# & Search \\
\hline 1. & exp fatty acids, omega-3/ \\
\hline 2. & $\begin{array}{l}\text { ((omega-3 or omega } 3 \text { or omega3) and fatty acid\$).mp. [mp=ti, ot, ab, nm, hw, kw, kf, } \\
\text { px, rx, ui, an, tx, sh, ct, bt, id, cc] }\end{array}$ \\
\hline 3. & fatty acids, essential/ \\
\hline 4. & linolenic acids/ \\
\hline 5. & exp fish oils/ \\
\hline 6. & $\begin{array}{l}\text { ((n } 3 \text { or n3 or n-3) and (oil\$ or pufa or fatty acid\$ or omega 3)).mp. [mp=ti, ot, ab, nm, } \\
\text { hw, kw, kf, px, rx, ui, an, tx, sh, ct, bt, id, cc] }\end{array}$ \\
\hline 7. & Docosahexaenoic Acids/ \\
\hline 8. & $\begin{array}{l}\text { docosahexa?noic.mp. [mp=ti, ot, ab, nm, hw, kw, kf, px, rx, ui, an, tx, sh, ct, bt, id, cc] or } \\
\text { docosapenta?noic.mp. }\end{array}$ \\
\hline 9. & Eicosapentaenoic Acid/ \\
\hline 10. & eicosapenta?noic.mp. [mp=ti, ot, ab, nm, hw, kw, kf, px, rx, ui, an, tx, sh, ct, bt, id, cc] \\
\hline 11. & icosapent?enoic.mp. [mp=ti, ot, ab, nm, hw, kw, kf, px, rx, ui, an, tx, sh, ct, bt, id, cc] \\
\hline 12. & $\begin{array}{l}\text { (alpha linolenic or alphalinolenic or alpha-linolenic).mp. [mp=ti, ot, ab, nm, hw, kw, kf, } \\
\text { px, rx, ui, an, tx, sh, ct, bt, id, cc] }\end{array}$ \\
\hline 13. & $\begin{array}{l}\text { (linolenate or cervonic or timnodonic or stearidonic).mp. [mp=ti, ot, ab, nm, hw, kw, kf, } \\
\text { px, rx, ui, an, tx, sh, ct, bt, id, cc] }\end{array}$ \\
\hline 14. & menhaden oil\$.mp. [mp=ti, ot, ab, nm, hw, kw, kf, px, rx, ui, an, tx, sh, ct, bt, id, cc] \\
\hline 15. & $\begin{array}{l}\text { ((flax or flaxseed or flax seed or linseed or rape seed or rapeseed or canola or soy or } \\
\text { soybean or walnut or mustard seed or perilla or shiso) adj2 oil\$).mp. [mp=ti, ot, ab, nm, } \\
\text { hw, kw, kf, px, rx, ui, an, tx, sh, ct, bt, id, cc] }\end{array}$ \\
\hline 16. & $\begin{array}{l}\text { (walnut\$ or butternut\$ or soybean\$ or pumpkin seed\$).mp. [mp=ti, ot, ab, nm, hw, kw, } \\
\text { kf, px, rx, ui, an, tx, sh, ct, bt, id, cc] }\end{array}$ \\
\hline 17. & (fish adj2 oil\$).mp. [mp=ti, ot, ab, nm, hw, kw, kf, px, rx, ui, an, tx, sh, ct, bt, id, cc] \\
\hline 18. & $\begin{array}{l}\text { (cod liver oil\$ or codliver oil\$ or marine oil\$ or marine fat\$).mp. [mp=ti, ot, ab, nm, hw, } \\
\text { kw, kf, px, rx, ui, an, tx, sh, ct, bt, id, cc] }\end{array}$ \\
\hline 19. & $\begin{array}{l}\text { (salmon or mackerel or herring or tuna or halibut or seaweed or anchov\$ or sardine\$).mp. } \\
\text { [mp=ti, ot, ab, nm, hw, kw, kf, px, rx, ui, an, tx, sh, ct, bt, id, cc] }\end{array}$ \\
\hline 20. & $\begin{array}{l}\text { (Ropufa or MaxEPA or Omacor or Efamed or ResQ or Epagis or Almarin or Coromega } \\
\text { or Lovaza or Vascepa or icosapent ethyl).mp. [mp=ti, ot, ab, nm, hw, kw, kf, px, rx, ui, } \\
\text { an, tx, sh, ct, bt, id, cc] }\end{array}$ \\
\hline 21. & $\begin{array}{l}\text { (fish consumption or fish intake or (fish adj2 diet\$)).mp. [mp=ti, ot, ab, nm, hw, kw, kf, } \\
\text { px, rx, ui, an, tx, sh, ct, bt, id, cc] }\end{array}$ \\
\hline 22. & $\begin{array}{l}\text { (mediterranean adj diet\$).mp. [mp=ti, ot, ab, nm, hw, kw, kf, px, rx, ui, an, tx, sh, ct, bt, } \\
\text { id, cc] }\end{array}$ \\
\hline 23. & $\begin{array}{l}\text { ((red blood cell or phospholipid or plasma fatty acid or plasma or phospholipid or } \\
\text { triacylglycerol or cholesteryl or ester or adipos\$ or fatty acid or erythrocyte or ghost or } \\
\text { platelet or granulocyte or neutrophil or mononuclear or LDL or HDL) and (DHA or } \\
\text { docosahexa?noic or Docosapenta?noic or EPA or eicosapenta?noic or SDA or linolenic } \\
\text { or stearidonic or omega)).mp. [mp=ti, ab, ot, nm, hw, kf, px, rx, ui, tx, kw, ct, sh, bt, id, } \\
\text { cc] }\end{array}$ \\
\hline 24. & or/1-23 \\
\hline
\end{tabular}




\begin{tabular}{|c|c|}
\hline 25. & (random\$ or rct\$).mp. [mp=ti, ot, ab, nm, hw, kw, kf, px, rx, ui, an, tx, sh, ct, bt, id, cc] \\
\hline 26. & exp randomized controlled trials/ \\
\hline 27. & exp Randomized Controlled Trials as Topic/ \\
\hline 28. & exp random allocation/ \\
\hline 29. & exp double-blind method/ \\
\hline 30. & exp single-blind method/ \\
\hline 31. & randomized controlled trial.pt. \\
\hline 32. & clinical trial.mp. [mp=ti, ot, ab, nm, hw, kw, kf, px, rx, ui, an, tx, sh, ct, bt, id, cc] \\
\hline 33. & (clin\$ adj trial\$).mp. [mp=ti, ot, ab, nm, hw, kw, kf, px, rx, ui, an, tx, sh, ct, bt, id, cc] \\
\hline 34. & $\begin{array}{l}\text { ((singl\$ or doubl\$ or trebl\$ or tripl\$) adj (blind\$ or mask\$)).mp. [mp=ti, ot, ab, nm, hw, } \\
\mathrm{kw}, \mathrm{kf}, \mathrm{px}, \mathrm{rx} \text {, ui, an, tx, sh, ct, bt, id, cc] }\end{array}$ \\
\hline 35. & exp placebos/ \\
\hline 36. & placebo\$.mp. [mp=ti, ot, ab, nm, hw, kw, kf, px, rx, ui, an, tx, sh, ct, bt, id, cc] \\
\hline 37. & randomly allocated.mp. [mp=ti, ot, ab, nm, hw, kw, kf, px, rx, ui, an, tx, sh, ct, bt, id, cc] \\
\hline 38. & $\begin{array}{l}\text { (allocated adj2 random\$).mp. [mp=ti, ot, ab, nm, hw, kw, kf, px, rx, ui, an, tx, sh, ct, bt, } \\
\text { id, cc] }\end{array}$ \\
\hline 39. & comparative study.mp. [mp=ti, ot, ab, nm, hw, kw, kf, px, rx, ui, an, tx, sh, ct, bt, id, cc] \\
\hline 40. & follow-up studies/ \\
\hline 41. & $\begin{array}{l}\text { (follow up or followup).mp. [mp=ti, ot, ab, nm, hw, kw, kf, px, rx, ui, an, tx, sh, ct, bt, id, } \\
\text { cc] }\end{array}$ \\
\hline 42. & exp case-control studies/ \\
\hline 43. & (case adj20 control).mp. [mp=ti, ot, ab, nm, hw, kw, kf, px, rx, ui, an, tx, sh, ct, bt, id, cc] \\
\hline 44. & exp longitudinal studies/ \\
\hline 45. & longitudinal.mp. [mp=ti, ot, ab, nm, hw, kw, kf, px, rx, ui, an, tx, sh, ct, bt, id, cc] \\
\hline 46. & exp cohort studies/ \\
\hline 47. & cohort.mp. [mp=ti, ot, ab, nm, hw, kw, kf, px, rx, ui, an, tx, sh, ct, bt, id, cc] \\
\hline 48. & exp prospective studies/ \\
\hline 49. & exp evaluation studies/ \\
\hline 50. & $\begin{array}{l}\text { (observational adj (study or studies)).mp. [mp=ti, ot, ab, nm, hw, kw, kf, px, rx, ui, an, tx, } \\
\text { sh, ct, bt, id, cc] }\end{array}$ \\
\hline 51. & Cross-Sectional Studies/ \\
\hline 52. & $\begin{array}{l}\text { (cross section\$ or cross-section\$).mp. [mp=ti, ot, ab, nm, hw, kw, kf, px, rx, ui, an, tx, sh, } \\
\text { ct, bt, id, cc] }\end{array}$ \\
\hline 53. & $\begin{array}{l}\text { food frequency questionnaire\$.mp. [mp=ti, ot, ab, nm, hw, kw, kf, px, rx, ui, an, tx, sh, } \\
\text { ct, bt, id, cc] }\end{array}$ \\
\hline 54. & or/25-53 \\
\hline 55. & 24 and 54 \\
\hline 56. & exp heart failure/ \\
\hline 57. & Heart failure\$.mp. [mp=ti, ot, ab, nm, hw, kw, kf, px, rx, ui, an, tx, sh, ct, bt, id, cc] \\
\hline 58. & exp pulmonary edema/ \\
\hline 59. & pulmonary edema.mp. [mp=ti, ot, ab, nm, hw, kw, kf, px, rx, ui, an, tx, sh, ct, bt, id, cc] \\
\hline 60. & pulmonary oedema.mp. [mp=ti, ot, ab, nm, hw, kw, kf, px, rx, ui, an, tx, sh, ct, bt, id, cc] \\
\hline 61. & $\begin{array}{l}\text { (ejection adj2 fraction).mp. [mp=ti, ot, ab, nm, hw, kw, kf, px, rx, ui, an, tx, sh, ct, bt, id, } \\
\text { cc] }\end{array}$ \\
\hline 62. & exp peripheral vascular diseases/ \\
\hline
\end{tabular}




\begin{tabular}{|c|c|}
\hline 63. & $\begin{array}{l}\text { (peripheral and vascular and disease\$).mp. [mp=ti, ot, ab, nm, hw, kw, kf, px, rx, ui, an, } \\
\text { tx, sh, ct, bt, id, cc] }\end{array}$ \\
\hline 64. & claudication.mp. [mp=ti, ot, ab, nm, hw, kw, kf, px, rx, ui, an, tx, sh, ct, bt, id, cc] \\
\hline 65. & exp arrhythmias, cardiac/ \\
\hline 66. & $\begin{array}{l}\text { (arrhythmi\$ or Antiarrhythmi\$).mp. [mp=ti, ot, ab, nm, hw, kw, kf, px, rx, ui, an, tx, sh, } \\
\text { ct, bt, id, cc] }\end{array}$ \\
\hline 67. & Fibrillation.mp. [mp=ti, ot, ab, nm, hw, kw, kf, px, rx, ui, an, tx, sh, ct, bt, id, cc] \\
\hline 68. & Flutter.mp. [mp=ti, ot, ab, nm, hw, kw, kf, px, rx, ui, an, tx, sh, ct, bt, id, cc] \\
\hline 69. & exp tachycardia/ \\
\hline 70. & tachycardia.mp. [mp=ti, ot, ab, nm, hw, kw, kf, px, rx, ui, an, tx, sh, ct, bt, id, cc] \\
\hline 71. & tachyarrhythmia.mp. [mp=ti, ot, ab, nm, hw, kw, kf, px, rx, ui, an, tx, sh, ct, bt, id, cc] \\
\hline 72. & exp bradycardia/ \\
\hline 73. & bradycardia.mp. [mp=ti, ot, ab, nm, hw, kw, kf, px, rx, ui, an, tx, sh, ct, bt, id, cc] \\
\hline 74. & exp death, sudden/ \\
\hline 75. & (sudden adj death).mp. [mp=ti, ot, ab, nm, hw, kw, kf, px, rx, ui, an, tx, sh, ct, bt, id, cc] \\
\hline 76. & or/56-75 \\
\hline 77. & 24 and 54 and 76 \\
\hline 78. & $\begin{array}{l}\text { limit } 77 \text { to (addresses or autobiography or bibliography or biography or case reports or } \\
\text { comment or congresses or dictionary or directory or editorial or festschrift or government } \\
\text { publications or historical article or interview or lectures or legal cases or legislation or } \\
\text { letter or news or newspaper article or patient education handout or periodical index) }\end{array}$ \\
\hline 79. & 77 not 78 \\
\hline 80. & limit 79 to english language \\
\hline 81. & limit 80 to humans \\
\hline 82. & (guidelines or practice guideline or meta analysis or systematic review).pt. \\
\hline 83. & (systematic\$ adj3 review\$).tw. \\
\hline 84. & 82 or 83 \\
\hline 85. & 24 and 76 and 84 \\
\hline 86. & 81 not 85 \\
\hline
\end{tabular}

\section{EMBASE searches run on 6/8/2015 \\ Search 1}

fatty AND acids, AND essential OR essential AND fatty AND ('acids'/exp OR acids) OR (n AND 3 OR n3 OR 'n 3' AND (oil* OR pufa OR fatty AND acid* OR omega AND 3 OR omega3 OR 'omega 3')) OR docosahexa*noic OR docosapenta*noic OR eicosapenta*noic OR icosapent*enoic OR (alpha AND linolenic OR alphalinolenic OR 'alpha linolenic' OR linolenic AND acids) OR (linoleic AND acid) OR cervonic OR timnodonic OR stearidonic OR (flaxseed OR flax AND seed OR linseed OR rape AND seed OR rapeseed OR canola OR soy OR soybean OR walnut OR mustard AND seed OR perilla OR shiso OR menhaden OR fish AND oil*) OR (walnut* OR butternut* OR soybean* OR pumpkin AND seed*) OR (cod AND liver AND oil* OR codliver AND oil* OR marine AND oil* OR marine AND fat*) OR salmon OR mackerel OR herring OR tuna OR halibut OR seaweed OR anchov* OR sardine* OR (ropufa OR maxepa OR omacor OR efamed OR resq OR epagis OR almarin OR coromega OR lovaza OR vascepa OR icosapent AND ethyl) OR (fish AND consumption OR fish AND intake) OR fish NEAR/2 diet* OR Mediterranean NEAR/2 diet* OR (red AND blood AND cell OR phospholipid OR plasma AND fatty AND acid OR plasma OR phospholipid OR triacylglycerol OR cholesteryl 
OR ester OR adipos* OR fatty AND acid OR erythrocyte OR ghost OR platelet OR granulocyte OR neutrophil OR mononuclear OR ldl OR hdl AND (dha OR docosahexa?noic OR docosapenta?noic OR epa OR eicosapenta?noic OR sda OR linolenic OR stearidonic OR omega))

AND ('cardiovascular disease' OR atherosclero* OR arteriosclero* OR cardioprotect* OR (coronary OR heart AND disease* OR myocardial AND infarct*) OR (cerebrovascular AND accident) OR stroke.mp OR (transient AND ischemic AND attack) OR tia OR lipid* OR cholesterol OR 'low density lipoprotein' OR 'high density lipoprotein' OR hyperlipidemia* OR hypertriglyceridem* OR dyslipidemia* OR (blood AND pressure) OR (diastol* OR systol* OR mean AND arterial) OR hypertension OR hemorrhag* OR 'bleeding')

AND (randomized AND controlled AND trial OR 'randomization' OR 'single blind procedure' OR 'double blind procedure' OR 'crossover procedure' OR 'placebo' OR rct OR (random* AND allocat*) OR (single AND blind*) OR (double AND blind*) OR (treble OR triple) NEAR/2 blind* OR (prospective AND study) OR 'clinical study' OR 'case control study' OR 'longitudinal study' OR 'retrospective study' OR 'prospective study' OR 'cohort analysis' OR cohort NEAR/2 (study OR studies) OR (case AND control NEAR/2 (study OR studies)) OR (follow AND up NEAR/2 (study OR studies)) OR observational NEAR/2 (study OR studies) OR (food AND frequency AND questionnaire*)) NOT ('abstract report' OR 'case study' OR 'case report') AND [humans]/lim AND [english]/lim AND [2000-2014]/py

\section{Search2}

fatty AND acids, AND essential OR essential AND fatty AND ('acids'/exp OR acids) OR (n AND 3 OR n3 OR 'n 3' AND (oil* OR pufa OR fatty AND acid* OR omega AND 3 OR omega3 OR 'omega 3')) OR docosahexa*noic OR docosapenta*noic OR eicosapenta*noic OR icosapent*enoic OR (alpha AND linolenic OR alphalinolenic OR 'alpha linolenic' OR linolenic AND acids) OR (linoleic AND acid) OR cervonic OR timnodonic OR stearidonic OR (flaxseed OR flax AND seed OR linseed OR rape AND seed OR rapeseed OR canola OR soy OR soybean OR walnut OR mustard AND seed OR perilla OR shiso OR menhaden OR fish AND oil*) OR (walnut* OR butternut* OR soybean* OR pumpkin AND seed*) OR (cod AND liver AND oil* OR codliver AND oil* OR marine AND oil* OR marine AND fat*) OR salmon OR mackerel OR herring OR tuna OR halibut OR seaweed OR anchov* OR sardine* OR (ropufa OR maxepa OR omacor OR efamed OR resq OR epagis OR almarin OR coromega OR lovaza OR vascepa OR icosapent AND ethyl) OR (fish AND consumption OR fish AND intake) OR fish NEAR/2 diet* OR mediterranean NEAR/2 diet* OR (red AND blood AND cell OR phospholipid OR plasma AND fatty AND acid OR plasma OR phospholipid OR triacylglycerol OR cholesteryl OR ester OR adipos* OR fatty AND acid OR erythrocyte OR ghost OR platelet OR granulocyte OR neutrophil OR mononuclear OR ldl OR hdl AND (dha OR docosahexa?noic OR docosapenta?noic OR epa OR eicosapenta?noic OR sda OR linolenic OR stearidonic OR omega))

AND ('cardiovascular disease' OR atherosclero* OR arteriosclero* OR cardioprotect* OR (coronary OR heart AND disease* OR myocardial AND infarct*) OR (cerebrovascular AND accident) OR stroke.mp OR (transient AND ischemic AND attack) OR tia OR lipid* OR cholesterol OR 'low density lipoprotein' OR 'high density lipoprotein' OR hyperlipidemia* OR hypertriglyceridem* OR dyslipidemia* OR (blood AND pressure) OR (diastol* OR systol* OR mean AND arterial) OR hypertension OR hemorrhag* OR 'bleeding') 
AND (randomized AND controlled AND trial OR 'randomization' OR 'single blind procedure' OR 'double blind procedure' OR 'crossover procedure' OR 'placebo' OR rct OR (random* AND allocat*) OR (single AND blind*) OR (double AND blind*) OR (treble OR triple) NEAR/2 blind* OR (prospective AND study) OR 'clinical study' OR 'case control study' OR 'longitudinal study' OR 'retrospective study' OR 'prospective study' OR 'cohort analysis' OR cohort NEAR/2 (study OR studies) OR (case AND control NEAR/2 (study OR studies)) OR (follow AND up NEAR/2 (study OR studies)) OR observational NEAR/2 (study OR studies) OR (food AND frequency AND questionnaire*)) NOT ('abstract report' OR 'case study' OR 'case report') AND [humans]/lim AND [english]/lim 


\section{Appendix B. \\ Inclusion criteria: Effects of Omega-3 Fatty Acids on Cardiovascular Disease}

\begin{tabular}{|c|c|}
\hline $\mathrm{P}$ & $\begin{array}{l}\text { - Healthy population without CVD or with low to intermediate CVD risk } \\
\text { Adults without CVD but with high risk (e.g., diabetes, metabolic syndrome, hypertension, dyslipidemia, } \\
\text { older age) } \\
\text { - Adults with clinical CVD (e.g., MI, stroke, angina with confirming clinical tests) } \\
\text { - Adults ( } \geq 18 \text { y) } \\
\text { o Include: Diabetes, Metabolic Syndrome, Hypertension, Dyslipidemia, existing CVD or symptoms } \\
\text { o Exclude: Selected for having non-CVD, non-DM related disease (eg, cancer, gastrointestinal } \\
\text { disease, dialysis, chronic renal failure, rheumatic disease) or condition (eg, pregnancy) }\end{array}$ \\
\hline $\mathrm{I} / \mathrm{C}$ & $\begin{array}{l}\text { - Intake:* } \\
\text { EPA, DHA, EPA+DHA, SDA, and/or ALA quantified (does not need to be quantified in } \\
\text { - } \\
\begin{array}{cl}\text { abstract, except Med diet) } \\
\text { Abstract needs to quantify the food or supplement (at a minimum) } \\
\text { o } & \text { Supplement, diet, or fortified foods (intervention or observational) } \\
0 & \text { Exclude: Dose } \geq 6 \text { g omega } 3 \text { (not total fish/plant oil) } \\
0 & \text { Exclude: Adherence to Med diet or Med diet score (unless omega-3 quantified [in abstract]) } \\
0 & \text { Exclude: Soy (or other) protein, soy isoflavones, other non-oil components } \\
0 & \text { Exclude: Weight loss diet (eg, fish/fish oil being used in a weight loss diet plan) } \\
0 & \text { Exclude: Combination interventions of omega-3 \& something else (eg, vitamin, E), but include if } \\
\text { o } & \text { all participants have the same other intervention (eg, vit E vs vit E + n-3) } \\
\text { - } & \text { Exclude: Comparator is an active intervention (eg, pravastatin) } \\
\text { Comarker: } \dagger \quad \text { Level measured (quantified) }\end{array} \\
\text { Comparator must be lower dose/exposure omega-3 or no supplement etc. (eg, not vs. statin) }\end{array}$ \\
\hline 0 & 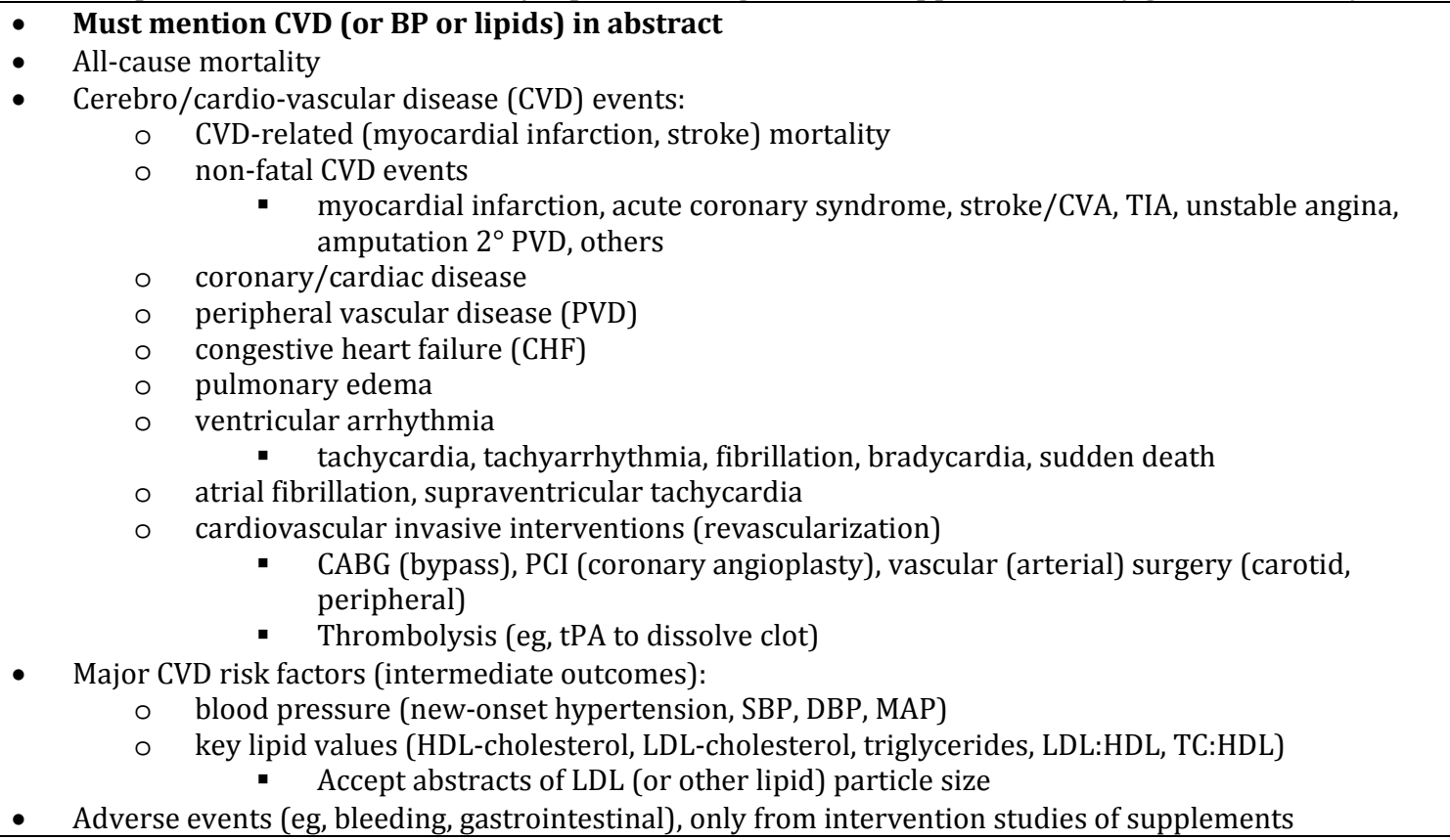 \\
\hline $\mathrm{D}$ & $\begin{array}{ll}- & \text { RCTs (all outcomes) } \\
\text { - } & \text { Randomized cross-over (XO) studies (blood pressure and lipids, adverse events) } \\
\text { - } & \text { Nonrandomized comparative studies, prospective or retrospective longitudinal (clinical outcomes, } \\
\text { adverse events): measure of n-3 intake/exposure must have occurred } \geq \mathbf{1} \text { year prior to } \\
\text { measurement of events } \\
\text { - } \quad \text { Prospective or retrospective cohort (single group) studies, where groups are compared based on n-3 FA }\end{array}$ \\
\hline
\end{tabular}




\begin{tabular}{|l|l|}
\hline intake or intake biomarker values (clinical outcomes) : measure of n-3 intake/exposure $\geq \mathbf{1}$ year prior \\
to events \\
Nested case-control studies (clinical outcomes) (case control study done within a prospective study): \\
measure of n-3 intake/exposure must have occurred $\geq \mathbf{1}$ year prior to measurement of events \\
- Exclude: cross-sectional (exposure and outcome measured at same time), case control (retrospective) \\
- UNCLEAR: observational studies for blood pressure and lipids [tag as maybe] \\
- Timing \\
$0 \quad$ Clinical outcomes, including new-onset hypertension: $\geq 1$ year follow-up \\
$0 \quad$ Intermediate outcomes (blood pressure and lipids): $\geq 1$ month follow-up \\
$0 \quad$ Adverse events: no minimum follow-up \\
Minimum sample sizes (per 2004 protocols*) \\
$0 \quad$ Clinical outcomes: RCT/nRCS: no minimum; Longitudinal single group $\mathrm{N} \geq 100$ \\
$0 \quad$ BP/Lipids (RCT): N $\geq \mathrm{x}$ (no minimum for now) \\
$0 \quad$ Adverse events: $\mathrm{N} \geq 100$ \\
Tag and REJECT trial protocols/designs
\end{tabular}




\section{Appendix C. Risk of Bias Criteria from the Original Report}

\section{Comparative Studies}

\begin{tabular}{|c|c|}
\hline Dimension & Instructions \\
\hline $\begin{array}{l}\text { Was the allocation sequence } \\
\text { (RANDOMIZATION METHOD) } \\
\text { adequately generated? }\end{array}$ & $\begin{array}{l}\text { There is a LOW RISK OF BIAS if the investigators describe a random } \\
\text { component in the sequence generation process such as: referring to a random } \\
\text { number table, using a computer random number generator, coin tossing, } \\
\text { shuffling cards or envelopes, throwing dice, drawing of lots. There is a } \\
\text { HIGH RISK OF BIAS if the investigators describe a non-random } \\
\text { component in the sequence generation process, such as: sequence generated } \\
\text { by odd or even date of birth, date (or day) of admission, hospital or clinic } \\
\text { record number; or allocation by judgement of the clinician, preference of the } \\
\text { participant, results of a laboratory test or a series of tests, or availability of } \\
\text { the intervention. IF HIGH RISK OF BIAS, EXPLAIN IN NOTES. }\end{array}$ \\
\hline $\begin{array}{l}\text { Was ALLOCATION adequately } \\
\text { concealed (prior to assignment)? }\end{array}$ & $\begin{array}{l}\text { There is a LOW RISK OF BIAS if the participants and investigators } \\
\text { enrolling participants could not foresee assignment because one of the } \\
\text { following, or an equivalent method, was used to conceal allocation: central } \\
\text { allocation (including telephone, web-based and pharmacy-controlled } \\
\text { randomization); sequentially numbered drug containers of identical } \\
\text { appearance; or sequentially numbered, opaque, sealed envelopes. There is a } \\
\text { HIGH RISK OF BIAS if participants or investigators enrolling participants } \\
\text { could possibly foresee assignments and thus introduce selection bias, such as } \\
\text { allocation based on: using an open random allocation schedule (e.g. a list of } \\
\text { random numbers); assignment envelopes were used without appropriate } \\
\text { safeguards (e.g. if envelopes were unsealed or non-opaque or not } \\
\text { sequentially numbered); alternation or rotation; date of birth; case record } \\
\text { number; or other explicitly unconcealed procedures. IF HIGH RISK OF } \\
\text { BIAS, EXPLAIN IN NOTES. }\end{array}$ \\
\hline $\begin{array}{l}\text { Were PARTICIPANTS adequately } \\
\text { BLINDED? }\end{array}$ & $\begin{array}{l}\text { There is a LOW RISK OF BIAS if blinding of participants was ensured and } \\
\text { it was unlikely that the blinding could have been broken; or if there was no } \\
\text { blinding or incomplete blinding, but the review authors judge that the } \\
\text { outcome is not likely to be influenced by lack of blinding. }\end{array}$ \\
\hline $\begin{array}{l}\text { Were OUTCOME ASSESSORS } \\
\text { adequately BLINDED? }\end{array}$ & $\begin{array}{l}\text { There is LOW RISK OF BIAS if the blinding of the outcome assessment } \\
\text { was ensured and it was unlikely that the blinding could have been broken; or } \\
\text { if there was no or incomplete blinding, but the outcome is unlikely to be } \\
\text { influenced by lack of blinding (ie, lab tests--lipids--inherently low risk of } \\
\text { bias, but not blood pressure). }\end{array}$ \\
\hline \multicolumn{2}{|l|}{$\begin{array}{l}\text { If outcome assessor blinding risk of bias is } \\
\text { different for different outcomes (eg, lipids } \\
\text { vs. MI), choose HIGH risk of bias and } \\
\text { describe in Notes }\end{array}$} \\
\hline $\begin{array}{l}\text { Incomplete outcome data (ATTRITION } \\
\text { BIAS) due to amount, nature or handling } \\
\text { of incomplete outcome data }\end{array}$ & $\begin{array}{l}\text { There is a LOW RISK OF BIAS if there were no missing outcome data; } \\
\text { reasons for missing outcome data were unlikely to be related to the true } \\
\text { outcome; missing outcome data were balanced in numbers, with similar } \\
\text { reasons for missing data across groups }(* * * * \text { The percentage of withdrawals } \\
\text { and drop-outs should not exceed } 20 \% \text { for short-term follow-up [ }<=1 \text { year] } \\
\left.\text { and } 30 \% \text { for long-term follow-up [ }>1 \text { year] }{ }^{* * * *}\right) \text {. IF HIGH RISK OF BIAS, } \\
\text { EXPLAIN IN NOTES. }\end{array}$ \\
\hline $\begin{array}{l}\text { If attrition risk of bias is different for } \\
\text { different outcomes (eg, lipids vs. MI) or } \\
\text { different time points (eg, } 1 \text { year vs. } 5 \\
\text { years), choose HIGH risk of bias and } \\
\text { describe in Notes }\end{array}$ & \\
\hline
\end{tabular}




\begin{tabular}{|c|c|}
\hline Dimension & Instructions \\
\hline $\begin{array}{l}\text { Is there evidence of SELECTIVE } \\
\text { OUTCOME REPORTING bias (Yes/No)? }\end{array}$ & $\begin{array}{l}\text { For LIPIDS, are only selected lipids/lipoproteins reported, were lipids } \\
\text { measured at baseline and was a blood sample taken at follow-up but follow- } \\
\text { up lipids were not reported, were subgroup lipid outcomes omitted? For } \\
\text { BLOOD PRESSURE, was BP measured at baseline and was there a follow- } \\
\text { up clinical encounter (where follow-up BP would have been measured), but } \\
\text { BP is not reported, were subgroup BP outcomes omitted? For CLINICAL } \\
\text { OUTCOMES, are all outcomes in the Methods section (all pre-specified } \\
\text { outcomes) reported, were all components of composite outcomes reported? } \\
\text { DESCRIBE ISSUES IN NOTES. }\end{array}$ \\
\hline $\begin{array}{l}\text { INTENTION-TO-TREAT analysis? } \\
\text { (Yes/No) }\end{array}$ & $\begin{array}{l}\text { YES if they state ITT and methods used were actually ITT, or **all** } \\
\text { participants were analyzed in the group to which they were allocated by } \\
\text { randomization (no cross-over). IF NO ITT, EXPLAIN IN NOTES. }\end{array}$ \\
\hline $\begin{array}{l}\text { Group SIMILARITY AT BASELINE } \\
\qquad\left({ }^{* *} \text { GENERAL }{ }^{* *}\right)\end{array}$ & $\begin{array}{c}\text { There is LOW RISK OF BIAS if groups are similar at baseline for } \\
\text { demographic and other factors ("Table 1"). Also LOW risk of bias if any } \\
\text { baseline differences were adjusted for in all relevant analyses. IF HIGH } \\
\text { RISK OF BIAS, EXPLAIN IN NOTES. }\end{array}$ \\
\hline $\begin{array}{l}\text { Group SIMILARITY AT BASELINE } \\
\qquad\left(* * \text { OMEGA- } 3^{* *}\right)\end{array}$ & $\begin{array}{l}\text { There is LOW RISK OF BIAS if groups were similar (or statistical } \\
\text { adjustments were made to account for differences) in omega-3 intake or } \\
\text { status (biomarkers) at baseline. There is HIGH RISK OF BIAS if groups had } \\
\text { different omega-3 intake/status at baseline that was not accounted for. There } \\
\text { is UNCLEAR RISK OF BIAS if baseline omega-3 status was not reported. }\end{array}$ \\
\hline $\begin{array}{l}\text { Was there incomplete COMPLIANCE } \\
\text { with interventions across groups? }\end{array}$ & $\begin{array}{l}\text { There is LOW RISK OF BIAS if compliance with the interventions was } \\
\text { acceptable ( }>=80 \% \text { across intervention duration), based on the reported } \\
\text { actual compliance compared to protocol or increased biomarker levels were } \\
\text { reported during or at the end of the intervention. There is HIGH RISK OF } \\
\text { BIAS if compliance was low ( }<80 \% \text { ) or no change in biomarker levels were } \\
\text { found during or at the end of the intervention. There is UNCLEAR RISK } \\
\text { OF BIAS if these data were not reported. }\end{array}$ \\
\hline $\begin{array}{l}\text { Additional Bias: Bias due to problems not } \\
\text { covered elsewhere in the table. }\end{array}$ & IF YES, EXPLAIN IN NOTES. \\
\hline
\end{tabular}

\section{Observational Studies}

\begin{tabular}{|c|c|}
\hline Dimension & Instructions \\
\hline $\begin{array}{l}\text { Selection bias (NOT NESTED CASE } \\
\text { CONTROL): Is there clear demonstration that } \\
\text { the outcome of interest was not present at the } \\
\text { start of the study (baseline)? }\end{array}$ & If the answer is no, the study will need to be reassessed for eligibility. \\
\hline $\begin{array}{l}\text { Comparability/Adjustment (ALL } \\
\text { OBSERVATIONAL STUDIES): Were the } \\
\text { analyses adjusted for confounders (or other } \\
\text { factors)? }\end{array}$ & $\begin{array}{l}\text { If YES, add to the Notes one of the following: ** Including diet and } \\
\text { CVD risk factors (eg, lipids, BP, DM) ** Including diet but not CVD } \\
\text { risk factors ** Including CVD risk factors, but not diet ** Neither diet } \\
\text { nor CVD risk factors ** If UNCLEAR, answer No. }\end{array}$ \\
\hline $\begin{array}{c}\text { Outcome assessment (ALL STUDIES): Were } \\
\text { OUTCOME ASSESSORS adequately } \\
\text { BLINDED? }\end{array}$ & $\begin{array}{l}\text { There is LOW RISK OF BIAS if the blinding of the outcome } \\
\text { assessment was ensured and it was unlikely that the blinding could } \\
\text { have been broken (independent blind assessment or record linkage). } \\
\text { UNCLEAR RISK OF BIAS if not or poorly reported. HIGH RISK OF } \\
\text { BIAS if self-report or other unblinded assessment. IF HIGH RISK OF } \\
\text { BIAS, EXPLAIN IN NOTES. }\end{array}$ \\
\hline $\begin{array}{l}\text { Incomplete outcome data (attrition bias) due to } \\
\text { amount, nature or handling of incomplete }\end{array}$ & $\begin{array}{l}\text { There is a LOW RISK OF BIAS if there were no missing outcome } \\
\text { data; reasons for missing outcome data were unlikely to be related to }\end{array}$ \\
\hline
\end{tabular}




\begin{tabular}{|c|c|}
\hline Dimension & Instructions \\
\hline outcome data (ALL STUDIES) & $\begin{array}{l}\text { the true outcome; missing outcome data were balanced in numbers, } \\
\text { with similar reasons for missing data across groups }(* * * * \text { The } \\
\text { percentage of withdrawals and drop-outs should not exceed } 20 \% \text { for } \\
\text { short-term follow-up ( } 1 \text { year) and } 30 \% \text { for long-term follow-up ( }>1 \\
\text { year) })^{* * *} \text { ). IF HIGH RISK OF BIAS, EXPLAIN IN NOTES. }\end{array}$ \\
\hline $\begin{array}{c}\text { Nutrition, FFQ Baseline intake: Was the dietary } \\
\text { assessment instrument (eg, FFQ) described to } \\
\text { have measured n-3 FA (ALL STUDIES WITH } \\
\text { FFQ)? }\end{array}$ & $\begin{array}{l}\text { If YES, answer Yes and add to the Notes one of the following: ** } \\
\text { Measured n-3 FA from BOTH diet and supplements ** Measured n-3 } \\
\text { FA from ONLY diet or ONLY supplements ** If NO (or UNCLEAR), } \\
\text { answer No and add to the Notes one of the following: ** Instrument } \\
\text { reported but no adequate description regarding n-3 FA intake } \\
\text { measurement ** No data on instrument or method used to measure n-3 } \\
\text { FA intake }\end{array}$ \\
\hline $\begin{array}{l}\text { Nutrition, Baseline data: Were the ranges or } \\
\text { distributions of the nutrient exposures } \\
\text { adequately reported (ie, quantile } \\
\text { means/medians SD and/or ranges) (ALL } \\
\text { OBSERVATIONAL STUDIES)? }\end{array}$ & $\begin{array}{c}\text { If analyzed in quantiles, we need the quantile thresholds AND the } \\
\text { mean or median within each quantile. If analyzed as a continuous } \\
\text { variable, we need overall mean or median and SD (or equivalent) or } \\
\text { range. }\end{array}$ \\
\hline $\begin{array}{l}\text { Additional Bias: Bias due to problems not } \\
\text { covered elsewhere in the table. }\end{array}$ & IF YES, EXPLAIN IN NOTES. \\
\hline $\begin{array}{c}\text { Do any specific outcomes have a high risk of } \\
\text { bias (different than others)? If so, describe in } \\
\text { Notes. }\end{array}$ & \\
\hline
\end{tabular}




\section{Appendix D. Excluded Studies}

\begin{tabular}{|c|c|c|c|c|}
\hline NCT Number & Title & Acronym & URL & Rejection Reason \\
\hline NCT00947635 & $\begin{array}{l}\text { Cholesterol and Fatty Acid } \\
\text { Synthesis in Islet and Liver } \\
\text { Transplant Patients and Effect of } \\
\text { Dietary Intervention }\end{array}$ & null & https://ClinicalTrials.gov/show/NCT00947635 & $\begin{array}{l}\text { P: not population of interest } \\
\text { (transplant) }\end{array}$ \\
\hline NCT00008801 & $\begin{array}{l}\text { hOKT3gamma1 (Ala-Ala) for the } \\
\text { Prevention of Human Islet Allograft } \\
\text { Failure }\end{array}$ & null & https://ClinicalTrials.gov/show/NCT00008801 & $\begin{array}{l}\text { P: not population of interest } \\
\text { (transplant) }\end{array}$ \\
\hline NCT00004827 & $\begin{array}{l}\text { Study of Docosahexaenoic Acid } \\
\text { (DHA) Supplementation in Patients } \\
\text { With X-Linked Retinitis } \\
\text { Pigmentosa }\end{array}$ & null & https://ClinicalTrials.gov/show/NCT00004827 & $\begin{array}{l}\text { P: not population of interest } \\
\text { (retinitis pigmentosa) }\end{array}$ \\
\hline NCT00620529 & $\begin{array}{l}\text { The Effects of Fish Oils on Blood } \\
\text { Pressure, Heart Rate Variability } \\
\text { and Liver Fat in the Polycystic } \\
\text { Ovary Syndrome }\end{array}$ & fops & https://ClinicalTrials.gov/show/NCT00620529 & $\begin{array}{l}\text { P: not population of interest } \\
\text { (PCOS) }\end{array}$ \\
\hline NCT00010842 & $\begin{array}{l}\text { Natural Antioxidants in the } \\
\text { Treatment of Multiple Sclerosis }\end{array}$ & null & https://ClinicalTrials.gov/show/NCT00010842 & $\begin{array}{l}\text { P: not population of interest } \\
\text { (MS) }\end{array}$ \\
\hline NCT00598910 & $\begin{array}{l}\text { Effect of Omacor on Triglycerides } \\
\text { in HIV Infected Subjects }\end{array}$ & null & https://ClinicalTrials.gov/show/NCT00598910 & $\begin{array}{l}\text { P: not population of interest } \\
\text { (HIV) }\end{array}$ \\
\hline NCT00691288 & $\begin{array}{l}\text { Effect of Omega-3 Fatty Acid } \\
\text { Supplementation on } \\
\text { Hypertriglyceridemia in HIV- } \\
\text { infected Children }\end{array}$ & null & https://ClinicalTrials.gov/show/NCT00691288 & $\begin{array}{l}\text { P: not population of interest } \\
\text { (HIV) }\end{array}$ \\
\hline NCT00296153 & $\begin{array}{l}\text { Omacor and Cardiovascular Risk } \\
\text { Factors in HIV Patients on HAART } \\
\text { Treatment }\end{array}$ & null & https://ClinicalTrials.gov/show/NCT00296153 & $\begin{array}{l}\text { P: not population of interest } \\
\text { (HIV) }\end{array}$ \\
\hline $\begin{array}{l}\text { EUCTR2007-001921-86- } \\
\text { DE }\end{array}$ & $\begin{array}{l}\text { A double-blind, placebo-controlled, } \\
\text { parallel-group, multi-center study } \\
\text { to investigate the effect of } \\
\text { Omacor? (n-3 PUFA) on lipid } \\
\text { parameters in HIV infected } \\
\text { patients treated with HAART }\end{array}$ & null & $\begin{array}{l}\text { https://www.clinicaltrialsregister.eu/ctr- } \\
\text { search/search?query=eudract_number:2007-001921-86 }\end{array}$ & $\begin{array}{l}\text { P: not population of interest } \\
\text { (HIV) }\end{array}$ \\
\hline NCT00678067 & $\begin{array}{l}\text { Effects of Docosahexaenoic and } \\
\text { Eicosapentaenoic Acids in } \\
\text { Hypercholesterolemic Children } \\
\text { Plus Diet on Docosahexaenoic } \\
\text { Acid (DHA) Status }\end{array}$ & DHA-RICHOIL & https://ClinicalTrials.gov/show/NCT00678067 & $\begin{array}{l}\text { P: not population of interest } \\
\text { (children) }\end{array}$ \\
\hline
\end{tabular}




\begin{tabular}{|c|c|c|c|c|}
\hline NCT00379171 & $\begin{array}{l}\text { Milk Types and Fish Oil in 9- to 12- } \\
\text { Month-Old Infants }\end{array}$ & null & https://ClinicalTrials.gov/show/NCT00379171 & $\begin{array}{l}\text { P: not population of interest } \\
\text { (children) }\end{array}$ \\
\hline NCT01457794 & OPUS School Meal Study & null & https://ClinicalTrials.gov/show/NCT01457794 & $\begin{array}{l}\text { P: not population of interest } \\
\text { (children) }\end{array}$ \\
\hline NCT01665742 & $\begin{array}{l}\text { Anti-inflammatory Dietary } \\
\text { Intervention in Overweight and } \\
\text { Obese Adolescents }\end{array}$ & null & https://ClinicalTrials.gov/show/NCT01665742 & $\begin{array}{l}\mathrm{P}: \text { not population of interest } \\
\text { (children) }\end{array}$ \\
\hline NCT00924274 & $\begin{array}{l}\text { Effect of Rapeseed Oil and } \\
\text { Sunflower Oil }\end{array}$ & null & https://ClinicalTrials.gov/show/NCT00924274 & $\begin{array}{l}\text { P: not population of interest } \\
\text { (children) }\end{array}$ \\
\hline NCT00924339 & Soy Food Intervention Trial & SOYFIT & https://ClinicalTrials.gov/show/NCT00924339 & $\begin{array}{l}\text { P: not population of interest } \\
\text { (children) }\end{array}$ \\
\hline NCT00929552 & $\begin{array}{l}\text { Effect of Fish Oil on Markers of the } \\
\text { Metabolic Syndrome in Overweight } \\
\text { Adolescent Boys }\end{array}$ & TeenFisk & https://ClinicalTrials.gov/show/NCT00929552 & $\begin{array}{l}\text { P: not population of interest } \\
\text { (children) }\end{array}$ \\
\hline NCT00586950 & $\begin{array}{l}\text { 123I-BMIPP SPECT Analysis for } \\
\text { Decreasing Cardiac Events in } \\
\text { Hemodialysis Patients }\end{array}$ & B-SAFE & https://ClinicalTrials.gov/show/NCT00586950 & $\begin{array}{l}\text { P: not population of interest } \\
\text { (acute lung injury) }\end{array}$ \\
\hline NCT01814956 & $\begin{array}{l}\text { Different Lipid Emulsions in Acute } \\
\text { Lung Injury Patients }\end{array}$ & null & https://ClinicalTrials.gov/show/NCT01814956 & $\begin{array}{l}\text { P: not population of interest } \\
\text { (acute lung injury) }\end{array}$ \\
\hline NCT02410668 & $\begin{array}{l}\text { The Effects of Flaxseed } \\
\text { Supplement on Weight and } \\
\text { Biochemical Factors in Overweight } \\
\text { and Obese Subject }\end{array}$ & null & https://ClinicalTrials.gov/show/NCT02410668 & I: Weight loss intervention \\
\hline ACTRN12610000750088 & $\begin{array}{l}\text { The Effect of Fish Oil Oral } \\
\text { Supplementation on Fat } \\
\text { Metabolism in Obese Subjects on } \\
\text { a Weight Loss Diet. }\end{array}$ & WIFA & http://www.anzctr.org.au/ACTRN12610000750088.aspx & I: Weight loss intervention \\
\hline NCT01799720 & $\begin{array}{l}\text { Oxidized Omega-3 Supplements } \\
\text { With Different Oxidation }\end{array}$ & GPTPASPAD & https://ClinicalTrials.gov/show/NCT01799720 & I: Weight loss intervention \\
\hline NCT00729430 & $\begin{array}{l}\text { Evaluating a Heart Magnetic } \\
\text { Resonance Imaging (MRI) } \\
\text { Procedure and the Effect of Fish } \\
\text { Oil Supplementation in People } \\
\text { Who Have Recently Had a Heart } \\
\text { Attack (The PROSPECT-CMR } \\
\text { Study) }\end{array}$ & Omega-REMODEL & https://ClinicalTrials.gov/show/NCT00729430 & $\begin{array}{l}\text { l: Not specifically n-3 } \\
\text { intervention/exposure }\end{array}$ \\
\hline NCT01343342 & $\begin{array}{l}\text { Genes, Omega-3 Fatty Acids and } \\
\text { Cardiovascular Disease Risk } \\
\text { Factors }\end{array}$ & FAS & https://ClinicalTrials.gov/show/NCT01343342 & $\begin{array}{l}\text { I: Not specifically n-3 } \\
\text { intervention/exposure }\end{array}$ \\
\hline NCT00410839 & $\begin{array}{l}\text { Studies of the Prevention of Atrial } \\
\text { Fibrillation by ALA }\end{array}$ & none & https://ClinicalTrials.gov/show/NCT00410839 & $\begin{array}{l}\text { l: Not specifically n-3 } \\
\text { intervention/exposure }\end{array}$ \\
\hline NCT01089231 & $\begin{array}{l}\text { Effects of Omega-3 Fatty Acids on } \\
\text { the Human Gene Expression }\end{array}$ & null & https://ClinicalTrials.gov/show/NCT01089231 & $\begin{array}{l}\text { I: Not specifically n-3 } \\
\text { intervention/exposure }\end{array}$ \\
\hline NCT00410020 & Arrhythmia Prevention With an & null & https://ClinicalTrials.gov/show/NCT00410020 & I: Not specifically n-3 \\
\hline
\end{tabular}




\begin{tabular}{|c|c|c|c|c|}
\hline & Alpha-Linolenic Enriched Diet & & & intervention/exposure \\
\hline NCT00487591 & $\begin{array}{l}\text { An Evaluation of Simvastatin Plus } \\
\text { Omacor Compared to Simvastatin } \\
\text { Plus Placebo in Subjects With } \\
\text { Mixed Dyslipidemia }\end{array}$ & null & https://ClinicalTrials.gov/show/NCT00487591 & $\begin{array}{l}\text { I: Not specifically n-3 } \\
\text { intervention/exposure }\end{array}$ \\
\hline NCT01384032 & $\begin{array}{l}\text { Study Into Genetic Influence on } \\
\text { Cholesterol Response to Dietary } \\
\text { Fat }\end{array}$ & Satgene & https://ClinicalTrials.gov/show/NCT01384032 & $\begin{array}{l}\text { I: Not specifically n-3 } \\
\text { intervention/exposure }\end{array}$ \\
\hline NCT01000194 & $\begin{array}{l}\text { Acute Fatty Acid Intervention } \\
\text { Study (AFAST) }\end{array}$ & AFAST & https://ClinicalTrials.gov/show/NCT01000194 & $\begin{array}{l}\text { I: Not specifically n-3 } \\
\text { intervention/exposure }\end{array}$ \\
\hline NCT01561846 & $\begin{array}{l}\text { Cheese Intake,CLA and } \\
\text { Hypercholesterolemia }\end{array}$ & CASU & https://ClinicalTrials.gov/show/NCT01561846 & $\begin{array}{l}\text { I: Not specifically n-3 } \\
\text { intervention/exposure }\end{array}$ \\
\hline NCT00655902 & $\begin{array}{l}\text { Copenhagen Obesity Risk } \\
\text { Assessment Study }\end{array}$ & COBRA & https://ClinicalTrials.gov/show/NCT00655902 & $\begin{array}{l}\text { I: Not specifically n-3 } \\
\text { intervention/exposure }\end{array}$ \\
\hline NCT00924937 & $\begin{array}{l}\text { CORonary Diet Intervention With } \\
\text { Olive Oil and Cardiovascular } \\
\text { PREVention }\end{array}$ & CORDIOPREV & https://ClinicalTrials.gov/show/NCT00924937 & $\begin{array}{l}\text { I: Not specifically n-3 } \\
\text { intervention/exposure }\end{array}$ \\
\hline ISRCTN35739639 & $\begin{array}{l}\text { Effects of Mediterranean diet on } \\
\text { the primary prevention of } \\
\text { cardiovascular disease }\end{array}$ & 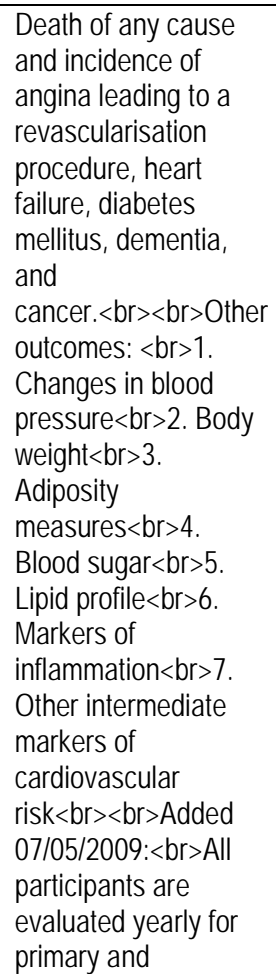 & http://isrctn.com/ISRCTN35739639 & $\begin{array}{l}\text { I: Not specifically n-3 } \\
\text { intervention/exposure }\end{array}$ \\
\hline
\end{tabular}




\begin{tabular}{|c|c|c|c|c|}
\hline & & secondary endpoints. & & \\
\hline NCT00520182 & $\begin{array}{l}\text { Dietary Interventions in Type } 2 \\
\text { Obese Diabetic Patients in the } \\
\text { Community }\end{array}$ & DIPAC & https://ClinicalTrials.gov/show/NCT00520182 & $\begin{array}{l}\text { I: Not specifically n-3 } \\
\text { intervention/exposure }\end{array}$ \\
\hline NCT00937963 & Healthy Fatty Acids in Transition & FAT & https://ClinicalTrials.gov/show/NCT00937963 & $\begin{array}{l}\text { I: Not specifically n-3 } \\
\text { intervention/exposure }\end{array}$ \\
\hline NCT02106208 & $\begin{array}{l}\text { Study of the Impact of Dairy Fat on } \\
\text { Cardiovascular Health. }\end{array}$ & HDL & https://ClinicalTrials.gov/show/NCT02106208 & $\begin{array}{l}\text { I: Not specifically n-3 } \\
\text { intervention/exposure }\end{array}$ \\
\hline NCT01314586 & Flax Lignans and Heart Health & ISULignan & https://ClinicalTrials.gov/show/NCT01314586 & $\begin{array}{l}\text { I: Not specifically n-3 } \\
\text { intervention/exposure }\end{array}$ \\
\hline NCT02027285 & $\begin{array}{l}\text { Nutrition, Health and Quality of } \\
\text { Life: Development of New } \\
\text { Formulations of Traditional } \\
\text { Products of the "Made in Italy" Diet } \\
\text { Optimized for Consumers With an } \\
\text { Age Over } 50 \text { Years (MIAO 50) }\end{array}$ & MIAO50 & https://ClinicalTrials.gov/show/NCT02027285 & $\begin{array}{l}\text { I: Not specifically n-3 } \\
\text { intervention/exposure }\end{array}$ \\
\hline NCT01679496 & $\begin{array}{l}\text { Fat Quality on Blood Lipids and } \\
\text { Immune Response }\end{array}$ & NoMa & https://ClinicalTrials.gov/show/NCT01679496 & $\begin{array}{l}\text { I: Not specifically n-3 } \\
\text { intervention/exposure }\end{array}$ \\
\hline NCT00445614 & $\begin{array}{l}\text { The Effects of Trout Fed With a } \\
\text { Vegetable Based Feed on } \\
\text { Cardiovascular Risk Markers and } \\
\text { Plasma Proteome }\end{array}$ & null & https://ClinicalTrials.gov/show/NCT00445614 & $\begin{array}{l}\text { I: Not specifically n-3 } \\
\text { intervention/exposure }\end{array}$ \\
\hline NCT00269425 & $\begin{array}{l}\text { The Heart Institute of Spokane } \\
\text { Diet Study }\end{array}$ & null & https://ClinicalTrials.gov/show/NCT00269425 & $\begin{array}{l}\text { I: Not specifically n-3 } \\
\text { intervention/exposure }\end{array}$ \\
\hline NCT00059254 & $\begin{array}{l}\text { Differential Metabolism of Dietary } \\
\text { Fatty Acids }\end{array}$ & null & https://ClinicalTrials.gov/show/NCT00059254 & $\begin{array}{l}\text { I: Not specifically n-3 } \\
\text { intervention/exposure }\end{array}$ \\
\hline NCT00535886 & $\begin{array}{l}\text { The Effects of Natural Versus } \\
\text { Man-Made Trans Fatty Acids on } \\
\text { Lipoprotein Profiles: A Pilot Study }\end{array}$ & null & https://ClinicalTrials.gov/show/NCT00535886 & $\begin{array}{l}\text { I: Not specifically n-3 } \\
\text { intervention/exposure }\end{array}$ \\
\hline NCT00274729 & $\begin{array}{l}\text { Mono Unsaturated Fatty Acids in } \\
\text { Obesity - Weight Maintenance and } \\
\text { Prevention of Lifestyle Diseases in } \\
\text { Obese Subjects. }\end{array}$ & null & https://ClinicalTrials.gov/show/NCT00274729 & $\begin{array}{l}\text { I: Not specifically n-3 } \\
\text { intervention/exposure }\end{array}$ \\
\hline NCT00074945 & $\begin{array}{l}\text { Obesity and Fatty Acid Flux } \\
\text { Comparison Trials }\end{array}$ & null & https://ClinicalTrials.gov/show/NCT00074945 & $\begin{array}{l}\text { I: Not specifically n-3 } \\
\text { intervention/exposure }\end{array}$ \\
\hline NCT01235832 & $\begin{array}{l}\text { The Effect of Avocado on } \\
\text { Cardiovascular Disease (CVD) } \\
\text { Risk Factors }\end{array}$ & null & https://ClinicalTrials.gov/show/NCT01235832 & $\begin{array}{l}\text { I: Not specifically n-3 } \\
\text { intervention/exposure }\end{array}$ \\
\hline NCT01023646 & $\begin{array}{l}\text { Glycemic Index - Variability Among } \\
\text { Individuals }\end{array}$ & null & https://ClinicalTrials.gov/show/NCT01023646 & $\begin{array}{l}\text { I: Not specifically n-3 } \\
\text { intervention/exposure }\end{array}$ \\
\hline NCT00429195 & $\begin{array}{l}\text { The Effect of Dietary Fat } \\
\text { Modification on Risk Factors } \\
\text { Associated With the Metabolic } \\
\text { Syndrome }\end{array}$ & null & https://ClinicalTrials.gov/show/NCT00429195 & $\begin{array}{l}\text { I: Not specifically n-3 } \\
\text { intervention/exposure }\end{array}$ \\
\hline
\end{tabular}




\begin{tabular}{|c|c|c|c|c|}
\hline NCT01621087 & $\begin{array}{l}\text { Dietary Linoleic Acid for Secondary } \\
\text { Prevention of Coronary Heart } \\
\text { Disease and Death in the Sydney } \\
\text { Heart Study: an RCT }\end{array}$ & null & https://ClinicalTrials.gov/show/NCT01621087 & $\begin{array}{l}\text { I: Not specifically n-3 } \\
\text { intervention/exposure }\end{array}$ \\
\hline NCT02506920 & $\begin{array}{l}\text { Gender Dependent Difference in } \\
\text { Lipemia After } 6 \text { x OFTT in Young } \\
\text { Healthy Subjects }\end{array}$ & null & https://ClinicalTrials.gov/show/NCT02506920 & $\begin{array}{l}\text { I: Not specifically } n-3 \\
\text { intervention/exposure }\end{array}$ \\
\hline NCT00400036 & $\begin{array}{l}\text { Dietary Fish Protein in Subjects } \\
\text { With Insulin Resistance }\end{array}$ & null & https://ClinicalTrials.gov/show/NCT00400036 & $\begin{array}{l}\text { I: Not specifically n-3 } \\
\text { intervention/exposure }\end{array}$ \\
\hline NCT00405197 & $\begin{array}{l}\text { MARIS Study; Mediterranean } \\
\text { Approach to Reduce Insulin- } \\
\text { Resistance Study }\end{array}$ & null & https://ClinicalTrials.gov/show/NCT00405197 & $\begin{array}{l}\text { I: Not specifically n-3 } \\
\text { intervention/exposure }\end{array}$ \\
\hline NCT00005513 & Framingham Nutrition Studies & null & https://ClinicalTrials.gov/show/NCT00005513 & $\begin{array}{l}\text { I: Not specifically n-3 } \\
\text { intervention/exposure }\end{array}$ \\
\hline NCT01710280 & $\begin{array}{l}\text { Palmitic Acid in the Sn-2 Position } \\
\text { of Triacylglycerols and } \\
\text { Postprandial Lipemia }\end{array}$ & null & https://ClinicalTrials.gov/show/NCT01710280 & $\begin{array}{l}\text { I: Not specifically n-3 } \\
\text { intervention/exposure }\end{array}$ \\
\hline NCT02145936 & $\begin{array}{l}\text { Effect of Dietary Fatty Acids on } \\
\text { Cardiovascular Disease Risk } \\
\text { Indicators and Inflammation }\end{array}$ & null & https://ClinicalTrials.gov/show/NCT02145936 & $\begin{array}{l}\text { I: Not specifically n-3 } \\
\text { intervention/exposure }\end{array}$ \\
\hline NCT01412346 & $\begin{array}{l}\text { Health Effects of a Nordic Diet } \\
\text { Rich in Plant-based Foods and } \\
\text { Fish }\end{array}$ & null & https://ClinicalTrials.gov/show/NCT01412346 & $\begin{array}{l}\text { I: Not specifically n-3 } \\
\text { intervention/exposure }\end{array}$ \\
\hline NCT01399216 & $\begin{array}{l}\text { Effects of a Supplement } \\
\text { Containing Fucoidan on Basal } \\
\text { Body Temperature }\end{array}$ & null & https://ClinicalTrials.gov/show/NCT01399216 & $\begin{array}{l}\text { I: Not specifically n-3 } \\
\text { intervention/exposure }\end{array}$ \\
\hline NCT02311790 & Palmitoleic Isomer Study & null & https://ClinicalTrials.gov/show/NCT02311790 & $\begin{array}{l}\text { I: Not specifically n-3 } \\
\text { intervention/exposure }\end{array}$ \\
\hline NCT00223574 & $\begin{array}{l}\text { Canadian Trial of Dietary } \\
\text { Carbohydrates in Diabetes }\end{array}$ & null & https://ClinicalTrials.gov/show/NCT00223574 & $\begin{array}{l}\text { I: Not specifically n-3 } \\
\text { intervention/exposure }\end{array}$ \\
\hline NCT01066091 & $\begin{array}{l}\text { Postprandial Inflammatory } \\
\text { Response in Healthy Men: Effect } \\
\text { of Dietary Fat Source, Obesity and } \\
\text { Age }\end{array}$ & null & https://ClinicalTrials.gov/show/NCT01066091 & $\begin{array}{l}\text { I: Not specifically n-3 } \\
\text { intervention/exposure }\end{array}$ \\
\hline NCT01241695 & $\begin{array}{l}\text { Safety, Acceptability and Efficacy } \\
\text { of a Long-term Intervention With a } \\
\text { Diabetes-specific Low- } \\
\text { carbohydrate, High-mono- } \\
\text { unsaturated Fatty Acid Containing } \\
\text { Oral Nutritional Supplement on } \\
\text { Glycaemic Control in Type } 2 \\
\text { Diabetic Patients }\end{array}$ & null & https://ClinicalTrials.gov/show/NCT01241695 & $\begin{array}{l}\text { I: Not specifically n-3 } \\
\text { intervention/exposure }\end{array}$ \\
\hline NCT00994513 & $\begin{array}{l}\text { Effect of Alpha Lipoic Acid on } \\
\text { Obesity Related Comorbidities }\end{array}$ & null & https://ClinicalTrials.gov/show/NCT00994513 & $\begin{array}{l}\text { I: Not specifically n-3 } \\
\text { intervention/exposure }\end{array}$ \\
\hline
\end{tabular}




\begin{tabular}{|c|c|c|c|c|}
\hline NCT01570270 & $\begin{array}{l}\text { Cheese Intake and } \\
\text { Hypercholesterolemia }\end{array}$ & null & https://ClinicalTrials.gov/show/NCT01570270 & $\begin{array}{l}\text { I: Not specifically n-3 } \\
\text { intervention/exposure }\end{array}$ \\
\hline NCT02086396 & $\begin{array}{l}\text { Effect of Weight Loss Diet and } \\
\text { Pumpkin Seed Flour Consumption } \\
\text { on Obese Women }\end{array}$ & null & https://ClinicalTrials.gov/show/NCT02086396 & $\begin{array}{l}\text { I: Not specifically n-3 } \\
\text { intervention/exposure }\end{array}$ \\
\hline NCT02391779 & $\begin{array}{l}\text { Flaxseed Lignan Supplementation } \\
\text { in Elderly Participants With Stage I } \\
\text { Hypertension }\end{array}$ & null & https://ClinicalTrials.gov/show/NCT02391779 & $\begin{array}{l}\text { I: Not specifically n-3 } \\
\text { intervention/exposure }\end{array}$ \\
\hline NCT00363233 & $\begin{array}{l}\text { The Potential Effects and } \\
\text { Mechanisms of Flax Lignans on } \\
\text { Type } 2 \text { Diabetes Mellitus }\end{array}$ & null & https://ClinicalTrials.gov/show/NCT00363233 & $\begin{array}{l}\text { I: Not specifically n-3 } \\
\text { intervention/exposure }\end{array}$ \\
\hline NCT01188902 & $\begin{array}{l}\text { The Metabolic Effect of Walnut } \\
\text { Consumption in Healthy Men and } \\
\text { Healthy Postmenopausal Women }\end{array}$ & null & https://ClinicalTrials.gov/show/NCT01188902 & $\begin{array}{l}\text { I: Not specifically } n-3 \\
\text { intervention/exposure }\end{array}$ \\
\hline NCT00204412 & $\begin{array}{l}\text { Exercise and Flax-Based } \\
\text { Nutritional Supplementation for } \\
\text { Lowering Cholesterol }\end{array}$ & null & https://ClinicalTrials.gov/show/NCT00204412 & $\begin{array}{l}\text { I: Not specifically n-3 } \\
\text { intervention/exposure }\end{array}$ \\
\hline CTRI/2009/091/001012 & $\begin{array}{l}\text { Effects of the walnut consumption } \\
\text { in the young male patients of } \\
\text { Essential Hypertension on sleep, } \\
\text { stress,blood pressure and various } \\
\text { parameters of Anthropometry. }\end{array}$ & null & http://www.ctri.nic.in/Clinicaltrials/pmaindet2.php?trialid=1148 & $\begin{array}{l}\text { I: Not specifically n-3 } \\
\text { intervention/exposure }\end{array}$ \\
\hline NCT00153764 & $\begin{array}{l}\text { Effectiveness of a Vitamin Mineral } \\
\text { Supplement }\end{array}$ & Omega-3 & https://ClinicalTrials.gov/show/NCT00153764 & $\begin{array}{l}\text { I: Not specifically n-3 } \\
\text { intervention/exposure }\end{array}$ \\
\hline NCT01696097 & $\begin{array}{l}\text { The Effects of Pork vs. } \\
\text { Chicken/Fish in a DASH Diet on } \\
\text { Blood Pressure Regulation in } \\
\text { Middle Aged and Older Adults }\end{array}$ & S31 & https://ClinicalTrials.gov/show/NCT01696097 & $\begin{array}{l}\text { I: Not specifically n-3 } \\
\text { intervention/exposure }\end{array}$ \\
\hline NCT02379169 & $\begin{array}{l}\text { Effects of Sea Buckthorn Oil and } \\
\text { Lutein on Eye Health }\end{array}$ & SBEYE & https://ClinicalTrials.gov/show/NCT02379169 & $\begin{array}{l}\text { I: Not specifically n-3 } \\
\text { intervention/exposure }\end{array}$ \\
\hline NCT00685581 & $\begin{array}{l}\text { Impact of Vaccenic Acid } \\
\text { Consumption on the Metabolism of } \\
\text { Saturated Fatty Acids: } \\
\text { Relationship With Cardiovascular } \\
\text { Risk Factors }\end{array}$ & TRANSQUAL WPC & https://ClinicalTrials.gov/show/NCT00685581 & $\begin{array}{l}\text { I: Not specifically n-3 } \\
\text { intervention/exposure }\end{array}$ \\
\hline NCT00901043 & $\begin{array}{l}\text { Effects of Walnut Consumption on } \\
\text { Endothelial Function in Type } 2 \\
\text { Diabetes }\end{array}$ & WALNUT & https://ClinicalTrials.gov/show/NCT00901043 & $\begin{array}{l}\text { I: Not specifically n-3 } \\
\text { intervention/exposure }\end{array}$ \\
\hline NCT01413646 & $\begin{array}{l}\text { Effects of Walnuts on Endothelial } \\
\text { Function in Overweight Adults With } \\
\text { at Least One Factor of Metabolic } \\
\text { Syndrome }\end{array}$ & Walnut2 & https://ClinicalTrials.gov/show/NCT01413646 & $\begin{array}{l}\text { I: Not specifically n-3 } \\
\text { intervention/exposure }\end{array}$ \\
\hline NCT02330848 & $\begin{array}{l}\text { Walnut Ingestion in Adults at Risk } \\
\text { for Diabetes: Effects on Body }\end{array}$ & Walnut3 & https://ClinicalTrials.gov/show/NCT02330848 & $\begin{array}{l}\text { I: Not specifically n-3 } \\
\text { intervention/exposure }\end{array}$ \\
\hline
\end{tabular}




\begin{tabular}{|c|c|c|c|c|}
\hline & $\begin{array}{l}\text { Composition, Diet Quality, and } \\
\text { Cardiac Risk Measures }\end{array}$ & & & \\
\hline NCT01471366 & $\begin{array}{l}\text { Method of Fish Oil Administration } \\
\text { on Patient Compliance }\end{array}$ & null & https://ClinicalTrials.gov/show/NCT01471366 & $\begin{array}{l}\text { C: Comparator not different } \\
\text { or no n-3 }\end{array}$ \\
\hline NCT01671254 & $\begin{array}{l}\text { Effect of Citrus } \\
\text { Bioflavonoids/Vitamin E in } \\
\text { Conjunction With Fish Oil } \\
\text { Supplementation }\end{array}$ & null & https://ClinicalTrials.gov/show/NCT01671254 & $\begin{array}{l}\text { C: Comparator not different } \\
\text { or no n-3 }\end{array}$ \\
\hline NCT02422446 & $\begin{array}{l}\text { Effects of Eicosapentaenoic Acid } \\
\text { on Endothelial Function in Diabetic } \\
\text { Subjects }\end{array}$ & null & https://ClinicalTrials.gov/show/NCT02422446 & $\begin{array}{l}\text { O: No outcome of interest (in } \\
\text { primary or secondary list) }\end{array}$ \\
\hline NCT02153073 & $\begin{array}{l}\text { Evaluation of the Safety and } \\
\text { Efficacy of Long-term Use of } \\
\text { Lotriga }\end{array}$ & null & https://ClinicalTrials.gov/show/NCT02153073 & $\begin{array}{l}\text { O: No outcome of interest (in } \\
\text { primary or secondary list) }\end{array}$ \\
\hline NCT00392717 & $\begin{array}{l}\text { Regulation of Lipoprotein } \\
\text { Metabolism in Obese Men }\end{array}$ & null & https://ClinicalTrials.gov/show/NCT00392717 & O: No outcome of interest \\
\hline JPRN-UMIN000017867 & $\begin{array}{l}\text { Consideration of cardiac function } \\
\text { improvement effect of Omega-3 } \\
\text { fatty acids }(E P A+D H A)\end{array}$ & null & http://www.umin.ac.jp/ctr/index.htm & O: No outcome of interest \\
\hline NCT00435045 & $\begin{array}{l}\text { Evaluation of Efficacy and Safety } \\
\text { of Omacor, Co-Administered With } \\
\text { Atorvastatin, in Subjects With } \\
\text { Hypertriglyceridemia }\end{array}$ & null & https://ClinicalTrials.gov/show/NCT00435045 & O: No outcome of interest \\
\hline NCT00728338 & $\begin{array}{l}\text { Docosahexenoic Acid (DHA) } \\
\text { Supplementation and } \\
\text { Cardiovascular Disease in Men } \\
\text { With High Triglycerides }\end{array}$ & null & https://ClinicalTrials.gov/show/NCT00728338 & O: No outcome of interest \\
\hline NCT01734538 & $\begin{array}{l}\text { Effect of } 12 \text { wk of Omega-3 FA } \\
\text { Supplementation on Metabolic and } \\
\text { Physical Health Parameters in } \\
\text { Older Adults }\end{array}$ & null & https://ClinicalTrials.gov/show/NCT01734538 & O: No outcome of interest \\
\hline NCT00149409 & $\begin{array}{l}\text { Omega-3-Polyunsaturated Fatty- } \\
\text { Acids (N3-Pufa) In Patients With } \\
\text { Severe Chronic Heart Failure }\end{array}$ & null & https://ClinicalTrials.gov/show/NCT00149409 & O: No outcome of interest \\
\hline NCT02132728 & $\begin{array}{l}\text { Impact of Flaxseed on the } \\
\text { Syndrome Metabolic Inflammation }\end{array}$ & null & https://ClinicalTrials.gov/show/NCT02132728 & $\begin{array}{l}\text { D: RCT } N<30 \text { per arm or } X O \\
N<20\end{array}$ \\
\hline NCT01505803 & $\begin{array}{l}\text { The Effect of a Nutritional } \\
\text { Supplement in Individuals With } \\
\text { Type } 2 \text { Diabetes Mellitus: a Pilot } \\
\text { Study }\end{array}$ & null & https://ClinicalTrials.gov/show/NCT01505803 & $\begin{array}{l}\text { D: RCT } N<30 \text { per arm or } X O \\
N<20\end{array}$ \\
\hline NCT00560014 & $\begin{array}{l}\text { Nutrient Levels Alter Transplant } \\
\text { Outcome }\end{array}$ & null & https://ClinicalTrials.gov/show/NCT00560014 & $\begin{array}{l}\text { D: RCT } N<30 \text { per arm or } \mathrm{XO} \\
\mathrm{N}<20\end{array}$ \\
\hline NCT02410161 & $\begin{array}{l}\text { Effect of an Alpha-linolenic Acid- } \\
\text { rich Supplement on Ketogenesis }\end{array}$ & null & https://ClinicalTrials.gov/show/NCT02410161 & $\begin{array}{l}\text { D: RCT } N<30 \text { per arm or } X O \\
N<20\end{array}$ \\
\hline
\end{tabular}




\begin{tabular}{|c|c|c|c|c|}
\hline & and Plasma Fatty Acids & & & \\
\hline NCT01896414 & $\begin{array}{l}\text { Metabolic Actions of Omega-3 } \\
\text { Fatty Acids }\end{array}$ & null & https://ClinicalTrials.gov/show/NCT01896414 & $\begin{array}{l}\text { D: RCT N<30 per arm or XO } \\
N<20\end{array}$ \\
\hline NCT02011906 & $\begin{array}{l}\text { The Effects of Omega } 3 \text { and } \\
\text { Vitamin E Supplementation on the } \\
\text { Serum Antioxidant Enzymes and } \\
\text { Gene Expressions of PGC-1a, h } \\
\text { TERT, FOXOs and SIRTs in CAD } \\
\text { Patients }\end{array}$ & null & https://ClinicalTrials.gov/show/NCT02011906 & $\begin{array}{l}\text { D: RCT } N<30 \text { per arm or } X O \\
N<20\end{array}$ \\
\hline NCT00935922 & $\begin{array}{l}\text { CCRC: Understanding the Effects } \\
\text { of Omega-3 Fatty Acids Versus } \\
\text { Lignans in Flaxseed on Metabolic } \\
\text { and Inflammatory Markers Leading } \\
\text { to Diabetes and Cardiovascular } \\
\text { Disease }\end{array}$ & null & https://ClinicalTrials.gov/show/NCT00935922 & $\begin{array}{l}\text { D: RCT } N<30 \text { per arm or } X O \\
N<20\end{array}$ \\
\hline NCT01788917 & $\begin{array}{l}\text { Effects of Supplementation With } \\
\text { Linseed Oil on Blood Lipids in } \\
\text { Vegetarians }\end{array}$ & null & https://ClinicalTrials.gov/show/NCT01788917 & $\begin{array}{l}\text { D: RCT N<30 per arm or XO } \\
N<20\end{array}$ \\
\hline NCT00694746 & $\begin{array}{l}\text { Study of Fish Oil to Reduce ALT } \\
\text { Levels in Adolescents }\end{array}$ & null & https://ClinicalTrials.gov/show/NCT00694746 & $\begin{array}{l}\text { D: RCT N<30 per arm or XO } \\
\mathrm{N}<20\end{array}$ \\
\hline NCT01180764 & $\begin{array}{l}\text { Effects of Lovaza on High Density } \\
\text { Lipoprotein (HDL) Composition } \\
\text { and Function in } \\
\text { Hypertriglyceridemia }\end{array}$ & null & https://ClinicalTrials.gov/show/NCT01180764 & $\begin{array}{l}\text { D: RCT N<30 per arm or } \mathrm{XO} \\
\mathrm{N}<20\end{array}$ \\
\hline NCT01594983 & $\begin{array}{l}\text { A Pilot Study to Assess the } \\
\text { Efficacy and Safety of LCQ908 } \\
\text { Alone and in Combination With } \\
\text { Fenofibrate or LovazaÂ } ® \text { in } \\
\text { Patients With Severe } \\
\text { Hypertriglyceridemia }\end{array}$ & null & https://ClinicalTrials.gov/show/NCT01594983 & $\begin{array}{l}\text { D: RCT N<30 per arm or } \mathrm{XO} \\
\mathrm{N}<20\end{array}$ \\
\hline NCT00715312 & $\begin{array}{l}\text { Effect of Oleic Acid on } \\
\text { Inflammation Markers and Blood } \\
\text { Lipid Metabolites: A Randomised, } \\
\text { Double-Blind, Crossover Study }\end{array}$ & null & https://ClinicalTrials.gov/show/NCT00715312 & $\begin{array}{l}\text { D: RCT N<30 per arm or XO } \\
N<20\end{array}$ \\
\hline JPRN-UMIN000002336 & $\begin{array}{l}\text { A fish-based diet intervention and } \\
\text { serum adiponectin concentration }\end{array}$ & null & http://www.umin.ac.jp/ctr/index.htm & $\begin{array}{l}\text { D: RCT N<30 per arm or } \mathrm{XO} \\
\mathrm{N}<20\end{array}$ \\
\hline JPRN-UMIN000013776 & $\begin{array}{l}\text { Effect of EPA/DHA combination } \\
\text { therapy on LDL particle size in } \\
\text { patients with hyperlipidemia and } \\
\text { type } 2 \text { diabetes taking HMG-CoA } \\
\text { reductive enzyme inhibitors and } \\
\text { DPP-4 inhibitors. }\end{array}$ & null & http://www.umin.ac.jp/ctr/index.htm & $\begin{array}{l}\text { D: RCT N<30 per arm or XO } \\
N<20\end{array}$ \\
\hline JPRN-UMIN000016714 & $\begin{array}{l}\text { Effect of ingestion of } \\
\text { eicosapentaenoic acid-rich fish oil }\end{array}$ & null & http://www.umin.ac.jp/ctr/index.htm & $\begin{array}{l}\text { D: RCT N<30 per arm or XO } \\
\mathrm{N}<20\end{array}$ \\
\hline
\end{tabular}




\begin{tabular}{|c|c|c|c|c|}
\hline & $\begin{array}{l}\text { on exercise performance in } \\
\text { swimming }\end{array}$ & & & \\
\hline JPRN-UMIN000017072 & $\begin{array}{l}\text { Double-Blind, Placebo-Controlled } \\
\text { Study for the Effect of Lyophilized } \\
\text { Herring-Roe Powder on Lipid } \\
\text { Metabolism Improvement }\end{array}$ & null & http://www.umin.ac.jp/ctr/index.htm & $\begin{array}{l}\text { D: RCT } N<30 \text { per arm or } X O \\
N<20\end{array}$ \\
\hline ChiCTR-IOR-15006329 & $\begin{array}{l}\text { Effect of long term small doses of } \\
\text { EPA/DHA supplement on } \\
\text { cardiovascular risk factors among } \\
\text { people with metabolic syndrome }\end{array}$ & null & http://www.chictr.org.cn/showproj.aspx?proj=10889 & $\begin{array}{l}\text { D: RCT } N<30 \text { per arm or } X O \\
N<20\end{array}$ \\
\hline ISRCTN22073289 & $\begin{array}{l}\text { The effect of dietary rapeseed } \\
\text { (canola) versus olive oil } \\
\text { supplementation on serum lipids, } \\
\text { liver enzymes and postprandial } \\
\text { inflammatory responses in adipose } \\
\text { tissue in obese men. }\end{array}$ & null & http://isrctn.com/ISRCTN22073289 & $\begin{array}{l}\text { D: RCT } N<30 \text { per arm or } X O \\
N<20\end{array}$ \\
\hline DRKS00006765 & $\begin{array}{l}\text { Influence of omega-3 fatty acids on } \\
\text { levels of oxylipins in blood and } \\
\text { urine }\end{array}$ & null & http://www.drks.de/DRKS00006765 & $\begin{array}{l}\text { D: RCT } N<30 \text { per arm or } \mathrm{XO} \\
\mathrm{N}<20\end{array}$ \\
\hline NCT00720655 & $\begin{array}{l}\text { Effects of Fatty and Lean Fish } \\
\text { Intake on Cardiovascular Risk } \\
\text { Factors in Subjects With Coronary } \\
\text { Heart Disease }\end{array}$ & null & https://ClinicalTrials.gov/show/NCT00720655 & $\begin{array}{l}\text { D: RCT } N<30 \text { per arm or } X O \\
N<20\end{array}$ \\
\hline NCT01244048 & $\begin{array}{l}\text { Intervention With n3 LC-PUFA- } \\
\text { supplemented Yogurt }\end{array}$ & null & https://ClinicalTrials.gov/show/NCT01244048 & $\begin{array}{l}\text { D: RCT } N<30 \text { per arm or } X O \\
N<20\end{array}$ \\
\hline NCT01705678 & $\begin{array}{l}\text { Investigation Into the Effects of } \\
\text { Krill Oil vs. Fish Oil on Markers of } \\
\text { Cardiovascular Disease }\end{array}$ & null & https://ClinicalTrials.gov/show/NCT01705678 & $\begin{array}{l}\text { D: RCT } N<30 \text { per arm or } \mathrm{XO} \\
\mathrm{N}<20\end{array}$ \\
\hline ACTRN12610000718044 & $\begin{array}{l}\text { Is fish intake or fish oil } \\
\text { supplementation better for people } \\
\text { with coronary heart disease? An } \\
\text { Australian secondary prevention } \\
\text { trial. }\end{array}$ & null & http://www.anzctr.org.au/ACTRN12610000718044.aspx & $\begin{array}{l}\text { D: RCT } N<30 \text { per arm or } X O \\
N<20\end{array}$ \\
\hline NCT00536185 & Heart \& Health Study & none & https://ClinicalTrials.gov/show/NCT00536185 & $\begin{array}{l}\text { D: RCT } N<30 \text { per arm or } X O \\
N<20\end{array}$ \\
\hline NCT01377402 & $\begin{array}{l}\text { ARgentinean Risk Assessment } \\
\text { Registry in ACS; the ARRA-RACS } \\
\text { Study }\end{array}$ & ARRA-RACS & https://ClinicalTrials.gov/show/NCT01377402 & $\begin{array}{l}\text { D: RCT } N<30 \text { per arm or } X O \\
N<20\end{array}$ \\
\hline NCT01047683 & $\begin{array}{l}\text { Efficacy and Safety of AMR101 } \\
\text { (Ethyl Icosapentate) in Patients } \\
\text { With Fasting Triglyceride (Tg) } \\
\text { Levels â\%o } 500 \text { and â\%o } 2000 \\
\text { mg/dL }\end{array}$ & MARINE & https://ClinicalTrials.gov/show/NCT01047683 & $\begin{array}{l}\text { D: RCT N<30 per arm or XO } \\
N<20\end{array}$ \\
\hline EUCTR2009-010520-25- & A Phase 3, Multi-Center, Placebo- & MARINE & https://www.clinicaltrialsregister.eu/ctr- & D: RCT N<30 per arm or XO \\
\hline
\end{tabular}




\begin{tabular}{|c|c|c|c|c|}
\hline NL & $\begin{array}{l}\text { Controlled, Randomized, } \\
\text { Double-Blind, 12-Week Study With } \\
\text { an Open-Label Extension } \\
\text { to Evaluate the Efficacy and Safety } \\
\text { of AMR101 in Patients } \\
\text { With Fasting Triglyceride Levels } \\
=>500 \mathrm{mg} / \mathrm{dL} \text { and <=2000 mg/dL: } \\
\text { The AMR101 MARINE Study } \\
\text { - The Marine Study }\end{array}$ & & search/search?query=eudract_number:2009-010520-25 & $\mathrm{N}<20$ \\
\hline ACTRN12605000207617 & $\begin{array}{l}\text { Fish Oils (Omega 3) in ischaemic } \\
\text { stroke }\end{array}$ & FOILS & http://www.anzctr.org.au/ACTRN12605000207617.aspx & $\begin{array}{l}\text { D: RCT N<30 per arm or XO } \\
N<20\end{array}$ \\
\hline NCT01437930 & $\begin{array}{l}\text { Intervention With n-3 } \\
\text { Polyunsaturated Fatty Acids } \\
\text { (PUFA)-Supplemented Products in } \\
\text { Moderate Hypertriglyceridemic } \\
\text { Patients }\end{array}$ & ZZ none & https://ClinicalTrials.gov/show/NCT01437930 & $\begin{array}{l}\text { D: RCT N<30 per arm or XO } \\
\mathrm{N}<20\end{array}$ \\
\hline ISRCTN76272133 & $\begin{array}{l}\text { Effects of fish oil on blood vessel } \\
\text { function }\end{array}$ & $\begin{array}{l}\text { Blood lipids, glucose, } \\
\text { insulin, inflammatory } \\
\text { markers, nitric oxide, } \\
\text { dietary } \\
\text { intake.<br><br>All } \\
\text { outcome measures to } \\
\text { be assessed at } \\
\text { baseline and after } 8 \\
\text { weeks intervention on } \\
\text { each arm of the } \\
\text { crossover study (i.e. } \\
\text { Week } 0 \text {, week } 8 \text {, } \\
\text { week } 16 \text { and week } \\
24 .\end{array}$ & http://isrctn.com/ISRCTN76272133 & $\begin{array}{l}\text { D: RCT } N<30 \text { per arm or } X O \\
N<20\end{array}$ \\
\hline NCT01737099 & $\begin{array}{l}\text { Efficacy and Safety Study of DHA- } \\
O \text { in Adults With } \\
\text { Hypertriglyceridemia }\end{array}$ & DHA-O & https://ClinicalTrials.gov/show/NCT01737099 & $\begin{array}{l}\text { D: RCT } N<30 \text { per arm or } X O \\
N<20\end{array}$ \\
\hline NCT02009865 & $\begin{array}{l}\text { EpanovaÂA for Lowering Very } \\
\text { High Triglycerides II (EVOLVE II) }\end{array}$ & EVOLVEII & https://ClinicalTrials.gov/show/NCT02009865 & $\begin{array}{l}\text { D: RCT N<30 per arm or XO } \\
\mathrm{N}<20\end{array}$ \\
\hline $\begin{array}{l}\text { EUCTR2012-003029-11- } \\
\text { DK }\end{array}$ & $\begin{array}{l}\text { A double-blind, placebo-controlled, } \\
\text { intervention trial comparing the } \\
\text { triglyceride-lowering effect of } \\
\text { omega-3 polyunsaturated fatty } \\
\text { acids, as either ethyl ester or } \\
\text { triglycerides in patients with } \\
\text { moderately elevated triglyceride } \\
\text { levels in the blood in non fasting } \\
\text { state. }\end{array}$ & EVT & $\begin{array}{l}\text { https://www.clinicaltrialsregister.eu/ctr- } \\
\text { search/search?query=eudract_number:2012-003029-11 }\end{array}$ & $\begin{array}{l}\text { D: RCT } N<30 \text { per arm or } \mathrm{XO} \\
\mathrm{N}<20\end{array}$ \\
\hline
\end{tabular}




\begin{tabular}{|c|c|c|c|c|}
\hline NCT01577056 & $\begin{array}{l}\text { Postprandial Lipid Metabolism in } \\
\text { Familial } \\
\text { Hypercholesterolaemia:Effects of } \\
\text { Fish Oils }\end{array}$ & FIFH & https://ClinicalTrials.gov/show/NCT01577056 & $\begin{array}{l}\text { D: RCT N<30 per arm or } \mathrm{XO} \\
\mathrm{N}<20\end{array}$ \\
\hline NCT00733772 & $\begin{array}{l}\text { Flaxseed Intervention on Metabolic } \\
\text { Syndrome }\end{array}$ & FIMS & https://ClinicalTrials.gov/show/NCT00733772 & $\begin{array}{l}\mathrm{D}: \mathrm{RCT} N<30 \text { per arm or } \mathrm{XO} \\
\mathrm{N}<20\end{array}$ \\
\hline NCT01916434 & $\begin{array}{l}\text { Farmed Fish Human Intervention } \\
\text { Study }\end{array}$ & FISHDISH & https://ClinicalTrials.gov/show/NCT01916434 & $\begin{array}{l}\text { D: RCT } N<30 \text { per arm or } X O \\
N<20\end{array}$ \\
\hline $\begin{array}{l}\text { EUCTR2013-004342-42- } \\
\text { NL }\end{array}$ & $\begin{array}{l}\text { The effect of fish oil on red blood } \\
\text { cell function and walking distance } \\
\text { in patients with arterial occlusion in } \\
\text { the legs }\end{array}$ & FISHTIC & $\begin{array}{l}\text { https://www.clinicaltrialsregister.eu/ctr- } \\
\text { search/search?query=eudract_number:2013-004342-42 }\end{array}$ & $\begin{array}{l}\text { D: RCT N<30 per arm or } X O \\
N<20\end{array}$ \\
\hline NCT02042274 & $\begin{array}{l}\text { Efficacy Study Regarding the } \\
\text { Beneficial Effects of Omega-3 } \\
\text { Fatty Acids on Cardiometabolic } \\
\text { Health }\end{array}$ & FOHS & https://ClinicalTrials.gov/show/NCT02042274 & $\begin{array}{l}\text { D: RCT N<30 per arm or XO } \\
N<20\end{array}$ \\
\hline NCT02400203 & $\begin{array}{l}\text { FREE Living Hulled HEMP Seed } \\
\text { and Oil Trial }\end{array}$ & FREEHEMP & https://ClinicalTrials.gov/show/NCT02400203 & $\begin{array}{l}\text { D: RCT N<30 per arm or } X O \\
N<20\end{array}$ \\
\hline NCT02211612 & $\begin{array}{l}\text { Overeating Different Fats and } \\
\text { Influence on Muscle Mass and } \\
\text { Body Fat Accumulation }\end{array}$ & LIPOGAIN-2 & https://ClinicalTrials.gov/show/NCT02211612 & $\begin{array}{l}\text { D: RCT } N<30 \text { per arm or } X O \\
N<20\end{array}$ \\
\hline NCT00286234 & $\begin{array}{l}\text { Niacin, N-3 Fatty Acids and Insulin } \\
\text { Resistance }\end{array}$ & null & https://ClinicalTrials.gov/show/NCT00286234 & $\begin{array}{l}\text { D: RCT N<30 per arm or } X O \\
N<20\end{array}$ \\
\hline NCT01129050 & $\begin{array}{l}\text { Effects of Omega-3 Fatty Acids on } \\
\text { Markers of Inflammation }\end{array}$ & null & https://ClinicalTrials.gov/show/NCT01129050 & $\begin{array}{l}\mathrm{D}: \mathrm{RCT} N<30 \text { per arm or } \mathrm{XO} \\
\mathrm{N}<20\end{array}$ \\
\hline NCT00246636 & $\begin{array}{l}\text { Evaluation of Efficacy and Safety } \\
\text { of Omacor (Omega-3-acid Ethyl } \\
\text { Esters) as Add-on Therapy in } \\
\text { Hypertriglyceridemic Subjects } \\
\text { Treated With Antara (Fenofibrate) } \\
\text { Followed by an 8-week Extension }\end{array}$ & null & https://ClinicalTrials.gov/show/NCT00246636 & $\begin{array}{l}\text { D: RCT N<30 per arm or } X O \\
N<20\end{array}$ \\
\hline NCT00927199 & $\begin{array}{l}\text { Efficacy of High-oleic Canola and } \\
\text { Flaxseed Oils for } \\
\text { Hypercholesterolemia and } \\
\text { Cardiovascular Disease Risk } \\
\text { Factors }\end{array}$ & null & https://ClinicalTrials.gov/show/NCT00927199 & $\begin{array}{l}\text { D: RCT } N<30 \text { per arm or } X O \\
N<20\end{array}$ \\
\hline NCT01145066 & $\begin{array}{l}\text { Botanical Oil Supplementation in } \\
\text { Diabetic and Metabolic Syndrome } \\
\text { Subjects }\end{array}$ & null & https://ClinicalTrials.gov/show/NCT01145066 & $\begin{array}{l}\text { D: RCT N<30 per arm or } \mathrm{XO} \\
\mathrm{N}<20\end{array}$ \\
\hline NCT01725646 & $\begin{array}{l}\text { An Efficacy and Safety Study of } \\
\text { OmacorÂ } ₫ \text { in Taiwanese } \\
\text { Hypertriglyceridemic Patients }\end{array}$ & null & https://ClinicalTrials.gov/show/NCT01725646 & $\begin{array}{l}\text { D: RCT N<30 per arm or XO } \\
N<20\end{array}$ \\
\hline NCT00315770 & $\begin{array}{l}\text { Health of Young European } \\
\text { Families and Fish Consumption }\end{array}$ & null & https://ClinicalTrials.gov/show/NCT00315770 & $\begin{array}{l}\text { D: RCT N<30 per arm or } X O \\
N<20\end{array}$ \\
\hline
\end{tabular}




\begin{tabular}{|c|c|c|c|c|}
\hline NCT01768429 & $\begin{array}{l}\text { The Effect of n-3 Fatty Acids and } \\
\text { Fish on Glucose and Lipid } \\
\text { Metabolism in Subjects With } \\
\text { Impaired Glucose Metabolism }\end{array}$ & null & https://ClinicalTrials.gov/show/NCT01768429 & $\begin{array}{l}\text { D: RCT N<30 per arm or XO } \\
N<20\end{array}$ \\
\hline NCT00350194 & $\begin{array}{l}\text { The Effects of Omega-3 Fatty } \\
\text { Acids on Metabolic Syndrome }\end{array}$ & null & https://ClinicalTrials.gov/show/NCT00350194 & $\begin{array}{l}\text { D: RCT N<30 per arm or } \mathrm{XO} \\
\mathrm{N}<20\end{array}$ \\
\hline NCT01749202 & $\begin{array}{l}\text { Effects of Stearidonic Acid- } \\
\text { Containing Foods on } \\
\text { Eicosapentaenoic Acid Levels in } \\
\text { Red Blood Cells and Omega-3 } \\
\text { Index }\end{array}$ & null & https://ClinicalTrials.gov/show/NCT01749202 & $\begin{array}{l}\text { D: RCT N<30 per arm or XO } \\
N<20\end{array}$ \\
\hline NCT00976872 & $\begin{array}{l}\text { Omega } 3 \text { Action on Cardiovascular } \\
\text { Risk Factors in Patients Treated } \\
\text { With Statins }\end{array}$ & null & https://ClinicalTrials.gov/show/NCT00976872 & $\begin{array}{l}\text { D: RCT N<30 per arm or XO } \\
N<20\end{array}$ \\
\hline NCT02092584 & $\begin{array}{l}\text { Effect of Omega-3 } \\
\text { Supplementation on Serum Level } \\
\text { and Gene Expression of IGF-1and } \\
\text { IGFBP-3 in Men With CVD. }\end{array}$ & null & https://ClinicalTrials.gov/show/NCT02092584 & $\begin{array}{l}\text { D: RCT N<30 per arm or } \mathrm{XO} \\
\mathrm{N}<20\end{array}$ \\
\hline NCT01478776 & $\begin{array}{l}\text { The Impact of Omega-3 } \\
\text { Supplementation on Gene } \\
\text { Expression in Type } 2 \text { Diabetics }\end{array}$ & null & https://ClinicalTrials.gov/show/NCT01478776 & $\begin{array}{l}\text { D: RCT N<30 per arm or XO } \\
N<20\end{array}$ \\
\hline NCT01365078 & $\begin{array}{l}\text { Stearidonic Acid and Lipid } \\
\text { Metabolism }\end{array}$ & null & https://ClinicalTrials.gov/show/NCT01365078 & $\begin{array}{l}\text { D: RCT N<30 per arm or XO } \\
\mathrm{N}<20\end{array}$ \\
\hline NCT00360217 & $\begin{array}{l}\text { The Triglyceride Lowering Effect of } \\
\text { an Omega-3 Fat (DHA) in Addition } \\
\text { to Statin Therapy for Patients With } \\
\text { CAD or Diabetes }\end{array}$ & null & https://ClinicalTrials.gov/show/NCT00360217 & $\begin{array}{l}\text { D: RCT } N<30 \text { per arm or } \mathrm{XO} \\
\mathrm{N}<20\end{array}$ \\
\hline NCT01712867 & $\begin{array}{l}\text { The Effect of Phytosterol Esters of } \\
\text { Omega-3 (Vayarol) Versus } \\
\text { Omega-3 Acids Ethyl Esters in } \\
\text { Reducing Triglyceride Levels }\end{array}$ & null & https://ClinicalTrials.gov/show/NCT01712867 & $\begin{array}{l}\text { D: RCT N<30 per arm or XO } \\
N<20\end{array}$ \\
\hline NCT01690312 & $\begin{array}{l}\text { Clinical Study to Assess High-DHA } \\
\text { Fish Oil on Biomarkers of } \\
\text { Cardiovascular Disease Risk in } \\
\text { Adults on Statin Therapy }\end{array}$ & null & https://ClinicalTrials.gov/show/NCT01690312 & $\begin{array}{l}\text { D: RCT } N<30 \text { per arm or } X O \\
N<20\end{array}$ \\
\hline NCT02035215 & $\begin{array}{l}\text { Phase } 3 \text { Study to Evaluate the } \\
\text { Efficacy and Safety of Omega-3- } \\
\text { acids Ethylesters } 90 \text { in Type â...jb } \\
\text { Hyperlipidemia }\end{array}$ & null & https://ClinicalTrials.gov/show/NCT02035215 & $\begin{array}{l}\text { D: RCT N<30 per arm or } \mathrm{XO} \\
\mathrm{N}<20\end{array}$ \\
\hline NCT02305355 & $\begin{array}{l}\text { Efficacy and Safety of Prescription } \\
\text { Omega-3 Fatty Acid Added to } \\
\text { Stable Statin Therapy in Patients } \\
\text { With Type } 2 \text { Diabetes and } \\
\text { Hypertriglyceridemia }\end{array}$ & null & https://ClinicalTrials.gov/show/NCT02305355 & $\begin{array}{l}\text { D: RCT N<30 per arm or XO } \\
N<20\end{array}$ \\
\hline
\end{tabular}




\begin{tabular}{|c|c|c|c|c|}
\hline NCT01526824 & $\begin{array}{l}\text { Lovaza's Effect on Clopidogrel in a } \\
\text { Neuro Population }\end{array}$ & null & https://ClinicalTrials.gov/show/NCT01526824 & $\begin{array}{l}\text { D: RCT N<30 per arm or XO } \\
\mathrm{N}<20\end{array}$ \\
\hline NCT01997268 & $\begin{array}{l}\text { The Efficacy of EPA+DHA } \\
\text { (SC401B) for Lowering } \\
\text { Triglyceride Levels (â\% } ¥ 500 \\
\text { mg/dL) }\end{array}$ & null & https://ClinicalTrials.gov/show/NCT01997268 & $\begin{array}{l}\text { D: RCT } N<30 \text { per arm or } \mathrm{XO} \\
\mathrm{N}<20\end{array}$ \\
\hline NCT02091583 & $\begin{array}{l}\text { Canola Oil, Fibre and DHA } \\
\text { Enhanced Clinical Trial }\end{array}$ & null & https://ClinicalTrials.gov/show/NCT02091583 & $\begin{array}{l}\text { D: RCT N<30 per arm or XO } \\
\mathrm{N}<20\end{array}$ \\
\hline NCT00758927 & $\begin{array}{l}\text { The Effects of Omega-3 Fatty Acid } \\
\text { (OMACOR) on the Low-density } \\
\text { Lipoprotein (LDL) Sub-fraction in } \\
\text { Type } 2 \text { Diabetic Patients }\end{array}$ & null & https://ClinicalTrials.gov/show/NCT00758927 & $\begin{array}{l}\text { D: RCT N<30 per arm or XO } \\
N<20\end{array}$ \\
\hline NCT01858948 & $\begin{array}{l}\text { SGA-induced Metabolic Syndrome } \\
\text { in Bipolar Youth }\end{array}$ & null & https://ClinicalTrials.gov/show/NCT01858948 & $\begin{array}{l}\text { D: RCT N<30 per arm or } \mathrm{XO} \\
\mathrm{N}<20\end{array}$ \\
\hline NCT00804427 & $\begin{array}{l}\text { Effect of Fish Oil on Plasma } \\
\text { Triglycerides in Adults }\end{array}$ & null & https://ClinicalTrials.gov/show/NCT00804427 & $\begin{array}{l}\text { D: RCT N<30 per arm or XO } \\
\mathrm{N}<20\end{array}$ \\
\hline NCT01028274 & $\begin{array}{l}\text { Safety and Efficacy of a Natural } \\
\text { Health Product in Reducing } \\
\text { Cholesterol and Triglyceride } \\
\text { Levels. }\end{array}$ & null & https://ClinicalTrials.gov/show/NCT01028274 & $\begin{array}{l}\text { D: RCT N<30 per arm or } X O \\
N<20\end{array}$ \\
\hline NCT02183922 & $\begin{array}{l}\text { Microencapsulated Fish Oil or } \\
\text { Conjugated Linoleic Acid in } \\
\text { Metabolic Syndrome }\end{array}$ & null & https://ClinicalTrials.gov/show/NCT02183922 & $\begin{array}{l}\text { D: RCT } N<30 \text { per arm or } X O \\
N<20\end{array}$ \\
\hline NCT01415388 & $\begin{array}{l}\text { Study to Investigate the Effects of } \\
\text { Krill Oil on Fasting Serum } \\
\text { Triglycerides }\end{array}$ & null & https://ClinicalTrials.gov/show/NCT01415388 & $\begin{array}{l}\text { D: RCT N<30 per arm or } X O \\
N<20\end{array}$ \\
\hline NCT02436369 & $\begin{array}{l}\text { The Effect of Yogurt Enriched With } \\
\text { Flaxseed on Cardiovascular Risk } \\
\text { Factors in Type } 2 \text { Diabetic Patients }\end{array}$ & null & https://ClinicalTrials.gov/show/NCT02436369 & $\begin{array}{l}\text { D: RCT N<30 per arm or XO } \\
N<20\end{array}$ \\
\hline NCT00746811 & $\begin{array}{l}\text { Trial to Assess the Effects of P- } \\
\text { OM3 on LDL-C in Subjects With } \\
\text { Primary Hypercholesterolemia }\end{array}$ & null & https://ClinicalTrials.gov/show/NCT00746811 & $\begin{array}{l}\text { D: RCT N<30 per arm or XO } \\
N<20\end{array}$ \\
\hline NCT00365742 & $\begin{array}{l}\text { Statin Therapy Vs. Therapeutic } \\
\text { Lifestyle Changes and } \\
\text { Supplements }\end{array}$ & null & https://ClinicalTrials.gov/show/NCT00365742 & $\begin{array}{l}\text { D: RCT N<30 per arm or XO } \\
N<20\end{array}$ \\
\hline NCT01604681 & $\begin{array}{l}\text { Supplementation With Flaxseed } \\
\text { Oil in the State of Rio de Janeiro }\end{array}$ & null & https://ClinicalTrials.gov/show/NCT01604681 & $\begin{array}{l}\text { D: RCT N<30 per arm or } \mathrm{XO} \\
\mathrm{N}<20\end{array}$ \\
\hline NCT00051415 & $\begin{array}{l}\text { Safety and Effectiveness of } \\
\text { Flaxseed for Reducing High } \\
\text { Cholesterol }\end{array}$ & null & https://ClinicalTrials.gov/show/NCT00051415 & $\begin{array}{l}\text { D: RCT } N<30 \text { per arm or } X O \\
N<20\end{array}$ \\
\hline NCT00852735 & $\begin{array}{l}\text { Effect of the Antioxidant } \\
\text { Micronutrients of Rapeseed Oil on } \\
\text { the Prevention of Cardiovascular } \\
\text { Diseases (Optim'Oils) }\end{array}$ & null & https://ClinicalTrials.gov/show/NCT00852735 & $\begin{array}{l}\text { D: RCT } N<30 \text { per arm or } \mathrm{XO} \\
\mathrm{N}<20\end{array}$ \\
\hline
\end{tabular}




\begin{tabular}{|c|c|c|c|c|}
\hline NCT02119429 & $\begin{array}{l}\text { Pumpkin Seed Oil } \\
\text { Supplementation in } \\
\text { Premenopausal Women }\end{array}$ & null & https://ClinicalTrials.gov/show/NCT02119429 & $\begin{array}{l}\text { D: RCT N<30 per arm or XO } \\
N<20\end{array}$ \\
\hline $\begin{array}{l}\text { EUCTR2006-003544-27- } \\
\text { NL }\end{array}$ & $\begin{array}{l}\text { An Evaluation of Simvastatin } 20 \\
\text { mg Plus Omacor } 4 \mathrm{~g} \text { Compared to } \\
\text { Simvastatin } 20 \text { mg Plus Placebo in } \\
\text { Subjects with Mixed Dyslipidemia }\end{array}$ & null & $\begin{array}{l}\text { https://www.clinicaltrialsregister.eu/ctr- } \\
\text { search/search?query=eudract_number:2006-003544-27 }\end{array}$ & $\begin{array}{l}\text { D: RCT } N<30 \text { per arm or XO } \\
N<20\end{array}$ \\
\hline ACTRN12605000641695 & $\begin{array}{l}\text { Effectiveness of DPA in } \\
\text { comparison to DHA in lowering } \\
\text { plasma triglyceride levels and } \\
\text { other cardiovascular risk factors }\end{array}$ & null & http://www.anzctr.org.au/ACTRN12605000641695.aspx & $\begin{array}{l}\text { D: RCT } N<30 \text { per arm or } X O \\
N<20\end{array}$ \\
\hline ACTRN12607000566437 & $\begin{array}{l}\text { Long Chain Omega-3 } \\
\text { Polyunsaturated Fatty Acids and } \\
\text { Heart Health in Humans }\end{array}$ & null & http://www.anzctr.org.au/ACTRN12607000566437.aspx & $\begin{array}{l}\text { D: RCT } N<30 \text { per arm or } X O \\
N<20\end{array}$ \\
\hline ChiCTR-TRC-12002014 & $\begin{array}{l}\text { Influence of different source of n-3 } \\
\text { fatty acid on plasma lipid in } \\
\text { moderately hypercholesterolemia } \\
\text { subject and the valid dosage }\end{array}$ & null & http://www.chictr.org/en/proj/show.aspx?proj=2638 & $\begin{array}{l}\text { D: RCT } N<30 \text { per arm or XO } \\
N<20\end{array}$ \\
\hline ACTRN12614000732684 & $\begin{array}{l}\text { The Aboriginal Cardiovascular } \\
\text { Omega-3 Randomised Controlled } \\
\text { Trial }\end{array}$ & null & http://www.anzctr.org.au/ACTRN12614000732684.aspx & $\begin{array}{l}\text { D: RCT } N<30 \text { per arm or } X O \\
N<20\end{array}$ \\
\hline ChiCTR-TRC-14005084 & $\begin{array}{l}\text { Effect of deep sea fish oil on blood } \\
\text { biochemical indicators in elderly } \\
\text { patients with type } 2 \text { diabetes } \\
\text { mellitus: an intervention study }\end{array}$ & null & http://www.chictr.org.cn/showproj.aspx?proj=4491 & $\begin{array}{l}\text { D: RCT } N<30 \text { per arm or } X O \\
N<20\end{array}$ \\
\hline ACTRN12615000472572 & $\begin{array}{l}\text { The effect of } 30 \text { day krill oil } \\
\text { supplementation on cardiovascular } \\
\text { risk factors }\end{array}$ & null & http://www.anzctr.org.au/ACTRN12615000472572.aspx & $\begin{array}{l}\text { D: RCT } N<30 \text { per arm or } X O \\
N<20\end{array}$ \\
\hline IRCT201411141525N5 & $\begin{array}{l}\text { Comparison of the effect of } \\
\text { Omega } 3 \text { capsules and fish } \\
\text { Consumption on Lipid Profile in } \\
\text { Patients with Dyslipidemia }\end{array}$ & null & http://www.irct.ir/searchresult.php?id=1525\&number=5 & $\begin{array}{l}\text { D: RCT } N<30 \text { per arm or } X O \\
N<20\end{array}$ \\
\hline IRCT201309303387N4 & $\begin{array}{l}\text { The effect of of aerobic training } \\
\text { plus Flax seed supplementation } \\
\text { on serum lipids and lipoprotein } \\
\text { profile and C-reactive protein in } \\
\text { sedentary obese women. }\end{array}$ & null & http://www.irct.ir/searchresult.php?id=3387\&number=4 & $\begin{array}{l}\text { D: RCT } N<30 \text { per arm or } X O \\
N<20\end{array}$ \\
\hline IRCT201207108559N3 & $\begin{array}{l}\text { Effect of omega-3 supplementation } \\
\text { and aerobic training on cardiac risk } \\
\text { factors }\end{array}$ & null & http://www.irct.ir/searchresult.php?id=8559\&number=3 & $\begin{array}{l}\text { D: RCT } N<30 \text { per arm or } X O \\
N<20\end{array}$ \\
\hline IRCT2013011312122N1 & $\begin{array}{l}\text { Effect of omega-3 fatty acid } \\
\text { supplementation on diabetes } \\
\text { mellitus patients }\end{array}$ & null & http://www.irct.ir/searchresult.php?id=12122\&number=1 & $\begin{array}{l}\text { D: RCT } N<30 \text { per arm or XO } \\
N<20\end{array}$ \\
\hline IRCT2012110411362N1 & Effect of fish oil supplement on & null & http://www.irct.ir/searchresult.php?id=11362\&number=1 & D: RCT N<30 per arm or XO \\
\hline
\end{tabular}




\begin{tabular}{|c|c|c|c|c|}
\hline & chronic atrial fibrillation & & & $\mathrm{N}<20$ \\
\hline NCT00504309 & $\begin{array}{l}\text { Vascular and Lipid Effects of } \\
\text { Omega-3 Fatty Acids in People } \\
\text { With Moderately Elevated } \\
\text { Triglycerides }\end{array}$ & OMEGA & https://ClinicalTrials.gov/show/NCT00504309 & $\begin{array}{l}\text { D: RCT N<30 per arm or } X O \\
N<20\end{array}$ \\
\hline NCT02195609 & $\begin{array}{l}\text { Evaluate the Effect of Omega-3 vs } \\
\text { Soy Isoflavones in } \\
\text { Postmenopausal Women With } \\
\text { Moderate to Severe Vasomotor } \\
\text { Symptoms }\end{array}$ & OMEGASI & https://ClinicalTrials.gov/show/NCT02195609 & $\begin{array}{l}\text { D: RCT } N<30 \text { per arm or } X O \\
N<20\end{array}$ \\
\hline NCT01928966 & $\begin{array}{l}\text { Effect of Pumpkin Seeds on the } \\
\text { Dietary Fatty Acid Intake and } \\
\text { Blood Pressure in Women }\end{array}$ & PSS1 & https://ClinicalTrials.gov/show/NCT01928966 & $\begin{array}{l}\text { D: RCT } N<30 \text { per arm or } X O \\
N<20\end{array}$ \\
\hline NCT02089035 & $\begin{array}{l}\text { Replacement of Saturated Fat in } \\
\text { Dairy on Total Cholesterol }\end{array}$ & RESET & https://ClinicalTrials.gov/show/NCT02089035 & $\begin{array}{l}\text { D: RCT } N<30 \text { per arm or } X O \\
N<20\end{array}$ \\
\hline $\begin{array}{l}\text { EUCTR2009-014730-22- } \\
\text { IT }\end{array}$ & $\begin{array}{l}\text { SO03-01 - EVALUATION OF THE } \\
\text { EFFECT OF N-3 } \\
\text { SUPPLEMENTATION ON } \\
\text { FUNCTIONAL IMPROVEMENT IN } \\
\text { POSTSTROKE PATIENTS - SO3- } \\
01\end{array}$ & SO3-01 & $\begin{array}{l}\text { https://www.clinicaltrialsregister.eu/ctr- } \\
\text { search/search?query=eudract_number:2009-014730-22 }\end{array}$ & $\begin{array}{l}\text { D: RCT } N<30 \text { per arm or } X O \\
N<20\end{array}$ \\
\hline NCT02036307 & $\begin{array}{l}\text { Supplementation With Omega-3: } \\
\text { Mechanism of Action }\end{array}$ & SOMA & https://ClinicalTrials.gov/show/NCT02036307 & $\begin{array}{l}\text { D: RCT N<30 per arm or } X O \\
N<20\end{array}$ \\
\hline NCT00934219 & Triglyceride Lowering Study & TGLL & https://ClinicalTrials.gov/show/NCT00934219 & $\begin{array}{l}\text { D: RCT } N<30 \text { per arm or } X O \\
N<20\end{array}$ \\
\hline NCT00441480 & $\begin{array}{l}\text { Effect of Plant Sterols Esterified to } \\
\text { Fish Oil Fatty Acids on Plasma } \\
\text { Lipid Levels }\end{array}$ & null & https://ClinicalTrials.gov/show/NCT00441480 & $\begin{array}{l}\text { D: RCT } N<30 \text { per arm or } X O \\
N<20\end{array}$ \\
\hline NCT00891293 & $\begin{array}{l}\text { A Second Open-Label Extension } \\
\text { of a Double-Blind, Parallel, Phase } \\
\text { IV Study to Assess the Efficacy } \\
\text { and Safety of Adjunctive } \\
\text { Lovazâ̂A (Formerly Known as } \\
\text { OmacôÂ } @ \text { ) Therapy in } \\
\text { Hypertriglyceridemic Subjects } \\
\text { Treated With Antaraâ, } ₫\end{array}$ & null & https://ClinicalTrials.gov/show/NCT00891293 & $\begin{array}{l}\text { D: RCT } N<30 \text { per arm or } X O \\
N<20\end{array}$ \\
\hline NCT02025920 & $\begin{array}{l}\text { Project Healthy Eating in Adults. A } \\
\text { Study on the Health Effects of Fish } \\
\text { Intake in Overweight Adults (FINS) }\end{array}$ & null & https://ClinicalTrials.gov/show/NCT02025920 & D: nRCS Lipids \\
\hline JPRN-UMIN000010397 & $\begin{array}{l}\text { Effect of combination therapy with } \\
\text { DPP-4 inhibitor and omega 3-fatty } \\
\text { acid on glycemic control in type2 } \\
\text { diabetes with dyslipidemia }\end{array}$ & null & http://www.umin.ac.jp/ctr/index.htm & D: nRCS Lipids \\
\hline
\end{tabular}




\begin{tabular}{|c|c|c|c|c|}
\hline NCT00527436 & $\begin{array}{l}\text { Fish Oil and Biomarkers of } \\
\text { Cardiovascular Risk }\end{array}$ & null & https://ClinicalTrials.gov/show/NCT00527436 & $\begin{array}{l}\text { D: Not enough information in } \\
\text { trial record }\end{array}$ \\
\hline NCT02130908 & $\begin{array}{l}\text { A Study on the Possible Health } \\
\text { Effects of Lean Fish, Fatty Fish } \\
\text { and Lean Meat Intake in Non- } \\
\text { obese Adults }\end{array}$ & FISK1 & https://ClinicalTrials.gov/show/NCT02130908 & $\begin{array}{l}\text { D: Not enough information in } \\
\text { trial record }\end{array}$ \\
\hline NCT02350595 & $\begin{array}{l}\text { A Study on the Possible Health } \\
\text { Effects of Lean Fish and Fatty Fish } \\
\text { Intake in Overweight or Obese } \\
\text { Adults }\end{array}$ & FISK2 & https://ClinicalTrials.gov/show/NCT02350595 & $\begin{array}{l}\text { D: Not enough information in } \\
\text { trial record }\end{array}$ \\
\hline NCT01119690 & $\begin{array}{l}\text { HÃameenlinna Metabolic } \\
\text { Syndrome Research Program: } \\
\text { Effects of Rapeseed Oil on Serum } \\
\text { Lipids and Platelet Function }\end{array}$ & HMS-03 & https://ClinicalTrials.gov/show/NCT01119690 & $\begin{array}{l}\text { D: Not enough information in } \\
\text { trial record }\end{array}$ \\
\hline NCT00000461 & $\begin{array}{l}\text { Harvard Atherosclerosis } \\
\text { Reversibility Project (HARP) }\end{array}$ & null & https://ClinicalTrials.gov/show/NCT00000461 & $\begin{array}{l}\text { D: Not enough information in } \\
\text { trial record }\end{array}$ \\
\hline NCT01821131 & $\begin{array}{l}\text { Flax Muffins and Cholesterol } \\
\text { Lowering }\end{array}$ & null & https://ClinicalTrials.gov/show/NCT01821131 & $\begin{array}{l}\text { D: Not enough information in } \\
\text { trial record }\end{array}$ \\
\hline NCT01952340 & $\begin{array}{l}\text { The Efficacy of Dietary Flaxseed } \\
\text { for the Reduction of Blood } \\
\text { Pressure in Newly Diagnosed } \\
\text { Hypertensive Individuals }\end{array}$ & null & https://ClinicalTrials.gov/show/NCT01952340 & $\begin{array}{l}\text { D: Not enough information in } \\
\text { trial record }\end{array}$ \\
\hline NCT00000511 & $\begin{array}{l}\text { Polyunsaturates and KCL to } \\
\text { Control Mild Hypertension }\end{array}$ & null & https://ClinicalTrials.gov/show/NCT00000511 & $\begin{array}{l}\text { D: Not enough information in } \\
\text { trial record }\end{array}$ \\
\hline NCT02069106 & $\begin{array}{l}\text { Efficacy Study of Daily Pro-Omega } \\
\text { LDL for Low-Density Lipoprotein } \\
\text { Cholesterol and Triglyceride } \\
\text { Reduction }\end{array}$ & PrOteCT & https://ClinicalTrials.gov/show/NCT02069106 & $\begin{array}{l}\text { D: Not enough information in } \\
\text { trial record }\end{array}$ \\
\hline NCT00841451 & $\begin{array}{l}\text { Pulmonary Vein Isolation } \\
\text { Outcomes With Fish Oils }\end{array}$ & PUFA & https://ClinicalTrials.gov/show/NCT00841451 & $\begin{array}{l}\text { D: Not enough information in } \\
\text { trial record }\end{array}$ \\
\hline NCT00005236 & $\begin{array}{l}\text { Atherosclerosis and Omega-3 } \\
\text { Fatty Acids in Alaskan Natives }\end{array}$ & null & https://ClinicalTrials.gov/show/NCT00005236 & D: Non-comparative \\
\hline NCT02349555 & $\begin{array}{l}\text { Nutritional Supplement Impact on } \\
\text { Metabolic Parameters }\end{array}$ & null & https://ClinicalTrials.gov/show/NCT02349555 & D: Non-comparative \\
\hline NCT00903409 & $\begin{array}{l}\text { Open-Label Extension of a } \\
\text { Randomized, Double-Blind, } \\
\text { Placebo-Controlled Study to } \\
\text { Assess the Efficacy and Safety of } \\
\text { LovazaÂA and Simvastatin } \\
\text { Therapy in Hypertriglyceridemic } \\
\text { Subjects }\end{array}$ & COMBOS & https://ClinicalTrials.gov/show/NCT00903409 & D: non-comparative \\
\hline NCT00404872 & $\begin{array}{l}\text { Evaluating the Relationship } \\
\text { Between Fatty Acids and Heart } \\
\text { Disease }\end{array}$ & null & https://ClinicalTrials.gov/show/NCT00404872 & D: non-comparative \\
\hline
\end{tabular}




\begin{tabular}{|c|c|c|c|c|}
\hline NCT02296385 & Genotype-related Effects of PUFA & null & https://ClinicalTrials.gov/show/NCT02296385 & D: non-comparative \\
\hline JPRN-UMIN000011169 & $\begin{array}{l}\text { Effect of EPA/DHA } \\
\text { supplementation added on DPP4 } \\
\text { inhibitors on lipid and glucose } \\
\text { metabolism in patients with type } 2 \\
\text { diabetes }\end{array}$ & null & http://www.umin.ac.jp/ctr/index.htm & D: non-comparative \\
\hline JPRN-JapicCTI-142680 & $\begin{array}{l}\text { Specified drug-use survey of } \\
\text { Lotriga Granular Capsules: } \\
\text { Outcome prevention on } \\
\text { Cardiovascular Events by } \\
\text { Antihyperlipidemic therapy with } \\
\text { N3-fatty acid in Japan (OCEAN3) }\end{array}$ & OCEAN3 & $\begin{array}{l}\text { http://www.clinicaltrials.jp/user/showCteDetailE.jsp?japicld=JapicCTI- } \\
142680\end{array}$ & D: non-comparative \\
\hline NCT01803594 & $\begin{array}{l}\text { Feeding Trial to Determine How } \\
\text { Combinations of Different Dietary } \\
\text { Bioactive Ingredients Influence } \\
\text { High Density Lipoprotein (HDL) } \\
\text { Metabolism }\end{array}$ & $\mathrm{HDL}$ & https://ClinicalTrials.gov/show/NCT01803594 & D: $<4$ wk followup \\
\hline NCT01175330 & $\begin{array}{l}\text { Omega } 3 \text { Fatty Acid Efficiency for } \\
\text { Prevention of Atrial Fibrillation } \\
\text { After Coronary Artery Bypass } \\
\text { Grafting }\end{array}$ & none & https://ClinicalTrials.gov/show/NCT01175330 & D: $<4$ wk followup \\
\hline NCT01908374 & $\begin{array}{l}\text { Bioavailability of EPA and DHA } \\
\text { From Two Dietary Supplements }\end{array}$ & null & https://ClinicalTrials.gov/show/NCT01908374 & D: $<4$ wk followup \\
\hline NCT02521779 & $\begin{array}{l}\text { The Role of Dietary Fat on } \\
\text { Postprandial Endotoxemia in } \\
\text { Healthy Adults }\end{array}$ & null & https://ClinicalTrials.gov/show/NCT02521779 & D: $<4$ wk followup \\
\hline NCT02246933 & $\begin{array}{l}\text { Effects of a PUFA-rich Diet on } \\
\text { Acute Metabolic and Inflammatory } \\
\text { High-Fat Meal Responses }\end{array}$ & null & https://ClinicalTrials.gov/show/NCT02246933 & D: $<4$ wk followup \\
\hline NCT01067911 & $\begin{array}{l}\text { Optimizing Dietary Fatty Acids to } \\
\text { Lower Metabolic Risk Factors } \\
\text { Among Canadians }\end{array}$ & null & https://ClinicalTrials.gov/show/NCT01067911 & D: $<4$ wk followup \\
\hline NCT02209766 & $\begin{array}{l}\text { A Ph1 Study in Healthy Male } \\
\text { Japanese and Caucasian After } \\
\text { Single and Multiple Doses of } \\
\text { D5884(Omega-3-carboxylic Acids) }\end{array}$ & null & https://ClinicalTrials.gov/show/NCT02209766 & D: $<4$ wk followup \\
\hline NCT00179400 & $\begin{array}{l}\text { Insulin Action in Individuals With } \\
\text { Type } 2 \text { Diabetes by Natural Fatty } \\
\text { Acids or the Medication } \\
\text { Pioglitazone }\end{array}$ & null & https://ClinicalTrials.gov/show/NCT00179400 & D: $<4$ wk followup \\
\hline NCT00475774 & $\begin{array}{l}\text { Body Fat Distribution and Fat } \\
\text { Metabolism }\end{array}$ & null & https://ClinicalTrials.gov/show/NCT00475774 & D: $<4$ wk followup \\
\hline NCT01579656 & $\begin{array}{l}\text { Effect of Flax, Poppy, Sesame \& } \\
\text { Salba on Postprandial Blood }\end{array}$ & null & https://ClinicalTrials.gov/show/NCT01579656 & D: $<4$ wk followup \\
\hline
\end{tabular}




\begin{tabular}{|c|c|c|c|c|}
\hline & $\begin{array}{l}\text { Glucose Response, Vascular, } \\
\text { Appetite \& Sensory Parameters }\end{array}$ & & & \\
\hline NCT01428960 & $\begin{array}{l}\text { Study of Acute Effects of Sn-1 and } \\
\text { Sn-3 Palmitic Acid-rich or Stearic } \\
\text { Acid-rich Fats on Metabolic } \\
\text { Markers }\end{array}$ & null & https://ClinicalTrials.gov/show/NCT01428960 & D: $<4$ wk followup \\
\hline NCT00465036 & $\begin{array}{l}\text { Effect of Flaxseed on Lipid Uptake } \\
\text { and Appetite }\end{array}$ & null & https://ClinicalTrials.gov/show/NCT00465036 & D: $<4$ wk followup \\
\hline NCT01124487 & $\begin{array}{l}\text { The Acute Effects of Oleic Acid } \\
\text { Enriched-diets on Lipids, Insulin } \\
\text { Sensitivity and Serum } \\
\text { Inflammatory Markers }\end{array}$ & null & https://ClinicalTrials.gov/show/NCT01124487 & D: $<4$ wk followup \\
\hline NCT00846937 & $\begin{array}{l}\text { Plant Stanol Ester Beverage and } \\
\text { lleostoma Patients }\end{array}$ & STOMA & https://ClinicalTrials.gov/show/NCT00846937 & D: $<4$ wk followup \\
\hline NCT00552084 & $\begin{array}{l}\text { Evaluating the Effectiveness of } \\
\text { Fish Oil Supplements at Reducing } \\
\text { the Recurrence of Atrial Fibrillation }\end{array}$ & null & https://ClinicalTrials.gov/show/NCT00552084 & $\mathrm{D}:<1$ yr CVD \\
\hline NCT01521845 & $\begin{array}{l}\text { Study of the Effect of omega3 on } \\
\text { Biomarkers of Cardiac Necrosis } \\
\text { (CKMB and Troponin I) and } \\
\text { Inflammation Marker (CRP) After } \\
\text { Elective Percutaneous Coronary } \\
\text { Intervention (PCI) }\end{array}$ & null & https://ClinicalTrials.gov/show/NCT01521845 & $\mathrm{D}:<1$ yr CVD \\
\hline NCT00402363 & $\begin{array}{l}\text { Evaluation of Efficacy and Safety } \\
\text { of Lovaza (Omega-3-Acid Ethyl } \\
\text { Esters) in Recurrent, Symptomatic } \\
\text { Atrial Fibrillation }\end{array}$ & null & https://ClinicalTrials.gov/show/NCT00402363 & $\mathrm{D}:<1$ yr CVD \\
\hline NCT00232245 & $\begin{array}{l}\text { Use of Fish Oils to Reduce the } \\
\text { Frequency and Duration of } \\
\text { Episodes of Atrial Fibrillation in } \\
\text { Patients With Paroxysmal Atrial } \\
\text { Fibrillation. }\end{array}$ & null & https://ClinicalTrials.gov/show/NCT00232245 & $\mathrm{D}:<1$ yr CVD \\
\hline JPRN-UMIN000011869 & $\begin{array}{l}\text { Relationship Between } \\
\text { Arteriosclerosis Obliterans and } \\
\text { Serum Level of Eicosapentaenoic } \\
\text { Acid as Prospective Interventional } \\
\text { Study }\end{array}$ & null & http://www.umin.ac.jp/ctr/index.htm & $\mathrm{D}:<1$ yr CVD \\
\hline JPRN-UMIN000013472 & $\begin{array}{l}\text { Clinical effect of early loading of } \\
\text { eicosepentanoic acid for acute } \\
\text { myocardial infarction: a } \\
\text { prospective, open-labeled, } \\
\text { randomized controlled clinical trial }\end{array}$ & null & http://www.umin.ac.jp/ctr/index.htm & $\mathrm{D}:<1$ yr CVD \\
\hline NCT01235130 & $\begin{array}{l}\text { Multi-center Study to Evaluate the } \\
\text { Effect of N-3 Fatty Acids (OMEGA- }\end{array}$ & AFFORD & https://ClinicalTrials.gov/show/NCT01235130 & $\mathrm{D}:<1$ yr CVD \\
\hline
\end{tabular}




\begin{tabular}{|l|l|l|l|l|}
\hline & $\begin{array}{l}\text { 3) on Arrhythmia Recurrence in } \\
\text { Atrial Fibrillation }\end{array}$ & & \\
\hline ISRCTN52203885 & $\begin{array}{l}\text { N-3 fatty acid supplementation on } \\
\text { arrhythmia recurrence in atrial } \\
\text { fibrillation }\end{array}$ & AFFORD & http://isrctn.com/ISRCTN52203885 & D: <1 yr CVD \\
\hline
\end{tabular}




\section{Appendix E. Studies in Both the Report and Registry}

Table E-1a. Studies in both the report and registry

\begin{tabular}{|c|c|c|c|c|c|c|c|}
\hline Study & Registry & Population & Dates & $\mathrm{N}$ total ${ }^{*}$ & Study design: Intervention & $\begin{array}{l}\text { Intermediate } \\
\text { Outcomes }\end{array}$ & Clinical Outcomes \\
\hline \multicolumn{8}{|l|}{ Has Results } \\
\hline $\begin{array}{l}\text { NCT01242527, US, Denmark, } \\
\text { Netherlands, Hungary, India, } \\
\text { Russian Federation, Ukraine, } \\
\text { EVOLVE }\end{array}$ & $\underline{\text { CT.gov }}$ & At risk & $\begin{array}{l}2011- \\
2012\end{array}$ & 399 & $\begin{array}{l}\text { RCT: Fish oil (EPA+DHA) 2, 3, or } 4 \mathrm{~g} / \mathrm{d} \\
\text { vs. Placebo }\end{array}$ & Lipids & \\
\hline NCT01408303, US, ESPRIT & $\underline{\text { CT.gov }}$ & At risk & $\begin{array}{l}2011- \\
2012\end{array}$ & 646 & $\begin{array}{l}\text { RCT: Fish oil (EPA+DHA) } 2 \text { or } 4 \text { g/d vs. } \\
\text { Placebo }\end{array}$ & Lipids & \\
\hline NCT01198275, Italy, ATRIA & $\underline{\text { CT.gov }}$ & $\begin{array}{l}\text { CVD, } \\
\text { existing }\end{array}$ & $\begin{array}{l}2006- \\
2008\end{array}$ & 199 & $\begin{array}{l}\text { RCT: Fish oil (EPA+DHA) 0.850-0.882 } \\
\text { g/d vs. Placebo }\end{array}$ & & Arrhythmia event \\
\hline $\begin{array}{l}\text { NCT00781950, Canada, } \\
\text { FLAXPAD }\end{array}$ & $\underline{\text { CT.gov }}$ & $\begin{array}{l}\text { CVD, } \\
\text { existing }\end{array}$ & $\begin{array}{l}2008- \\
2014 \\
\end{array}$ & 110 & RCT: ALA 30 g/d vs. Placebo & BP/Lipids & $\begin{array}{l}\text { Cardiac event, Stroke/TIA, } \\
\text { Death }\end{array}$ \\
\hline \multicolumn{8}{|l|}{ No Results } \\
\hline NCT00005133, US, CHS & $\underline{\text { CT.gov }}$ & Healthy & $\begin{array}{l}1988- \\
2009\end{array}$ & nd & Observational - Quantile & & Cardiac event, Stroke/TIA \\
\hline NCT01313988, Sweden, none & $\underline{\text { CT.gov }}$ & Healthy & $\begin{array}{l}2011- \\
2012 \\
\end{array}$ & 332 & RCT: All n-3 PUFA vs. Placebo & Lipids & \\
\hline $\begin{array}{l}\text { NCT00110838, Germany, } \\
\text { Netherlands, UK, Austria, } \\
\text { Belgium, Czech Republic, Poland, } \\
\text { Switzerland, SOFA }\end{array}$ & $\underline{\text { CT.gov }}$ & Healthy & $\begin{array}{l}2010- \\
2011\end{array}$ & 256 & $\begin{array}{l}\text { RCT: Fish oil (EPA+DHA) } 2 \text { g/d vs. } \\
\text { Placebo }\end{array}$ & Lipids & \\
\hline NCT00266292, Denmark, none & $\underline{\text { CT.gov }}$ & Healthy & $\begin{array}{l}2005- \\
2006\end{array}$ & 60 & RCT: Fish oil (EPA+DHA) vs. Placebo & BP/Lipids & \\
\hline NCT01856179, Germany, none & $\underline{\text { CT.gov }}$ & Healthy & $\begin{array}{l}2011- \\
2012 \\
\end{array}$ & 78 & RCT: SDA 15-18 g/d vs. nd & Lipids & \\
\hline NCT00317707, Italy, none & $\underline{\text { CT.gov }}$ & At risk & $\begin{array}{l}2004- \\
2011\end{array}$ & 12513 & RCT: All n-3 PUFA vs. Placebo & & Cardiac event, Death \\
\hline $\begin{array}{l}\text { NCT00141232/ISRCTN76737502, } \\
\text { UK, AFFORD }\end{array}$ & $\frac{\text { ICTRPI }}{\text { CT.gov }}$ & At risk & $\begin{array}{l}2004- \\
2006\end{array}$ & 810 & RCT: Fish oil (EPA+DHA) vs. Placebo & Lipids & \\
\hline NCT00246701, US, COMBOS & CT.gov & At risk & $2005-$ & 256 & RCT: Fish oil (EPA+DHA) vs. Placebo & Lipids & \\
\hline NCT00069784, Canada, ORIGIN & $\underline{\text { CT.gov }}$ & At risk & $\begin{array}{l}2003- \\
2011 \\
\end{array}$ & 12537 & $\begin{array}{l}\text { RCT: Fish oil (EPA+DHA) } 0.84 \text { g/d vs. } \\
\text { Placebo }\end{array}$ & & $\begin{array}{l}\text { Cardiac event, Stroke/TIA, } \\
\text { Death }\end{array}$ \\
\hline $\begin{array}{l}\text { NCT01758601, Spain, WISH- } \\
\text { CARE }\end{array}$ & $\underline{\text { CT.gov }}$ & At risk & $\begin{array}{l}2010- \\
2012 \\
\end{array}$ & 273 & $\begin{array}{l}\text { RCT - XO: Fish oil (EPA+DHA) } 1 \text { serving } \\
\text { of hake/day vs. no intervention }\end{array}$ & Lipids & \\
\hline NCT00231738, Japan, JELIS & $\underline{\text { CT.gov }}$ & At risk & $\begin{array}{l}1996- \\
2004\end{array}$ & 18000 & RCT: EPA $1.8 \mathrm{~g} / \mathrm{d}$ vs. nd & & $\begin{array}{l}\text { Cardiac event, Stroke/TIA, } \\
\text { Death }\end{array}$ \\
\hline
\end{tabular}




\begin{tabular}{|c|c|c|c|c|c|c|c|}
\hline NCT01047501, US, ANCHOR & $\underline{\text { CT.gov }}$ & At risk & $\begin{array}{ll}2009- \\
2011\end{array}$ & 702 & RCT: EPA 2 or 4 g/d vs. Placebo & Lipids & \\
\hline NCT01351012, Canada, COMIT & $\underline{\text { CT.gov }}$ & At risk & $\begin{array}{l}2010- \\
2012\end{array}$ & 140 & $\begin{array}{l}\text { RCT - XO: ALA, DHA + ALA DHA 7.2, } \\
\text { ALA 4.2-13.8 vs. ALA 4.2-13.8 g/d }\end{array}$ & Lipids & \\
\hline DRKS00006232, Germany, MSX & ICTRP & At risk & $\begin{array}{l}2009- \\
2009\end{array}$ & 81 & RCT: ALA $3.5 \mathrm{~g} / \mathrm{d}$ vs. ALA $0.9 \mathrm{~g} / \mathrm{d}$ & BP/Lipids & \\
\hline NCT00004558, US, none & $\underline{\text { CT.gov }}$ & $\begin{array}{l}\text { CVD, } \\
\text { existing }\end{array}$ & $\begin{array}{ll}1999- \\
2004\end{array}$ & 200 & $\begin{array}{l}\text { RCT: Omega-3 (Unspecified) vs. } \\
\text { Placebo }\end{array}$ & & Arrhythmia event \\
\hline $\begin{array}{l}\text { NCT00127452, Netherlands, } \\
\text { Alpha Omega }\end{array}$ & $\underline{\text { CT.gov }}$ & $\begin{array}{l}\text { CVD, } \\
\text { existing }\end{array}$ & $\begin{array}{l}2002- \\
2010\end{array}$ & 4837 & $\begin{array}{l}\text { RCT: All n-3 PUFA Fish oil } 0.4 \text { g/d, ALA } 2 \\
\text { g/d vs. Placebo }\end{array}$ & & $\begin{array}{l}\text { Cardiac event, Stroke/TIA, } \\
\text { Arrhythmia event, PVD } \\
\text { event, Death }\end{array}$ \\
\hline $\begin{array}{l}\text { NCT00251134, Germany, } \\
\text { OMEGA }\end{array}$ & $\underline{\text { CT.gov }}$ & $\begin{array}{l}\text { CVD, } \\
\text { existing }\end{array}$ & $\begin{array}{ll}2003- \\
2008\end{array}$ & 3800 & RCT: All n-3 PUFA 1 g/d vs. Placebo & & $\begin{array}{l}\text { Cardiac event, Arrhythmia } \\
\text { event, Death }\end{array}$ \\
\hline NCT00336336, Italy, GISSI-HF & $\underline{\text { CT.gov }}$ & $\begin{array}{l}\text { CVD, } \\
\text { existing }\end{array}$ & $\begin{array}{l}2002- \\
2008\end{array}$ & 6975 & RCT: All n-3 PUFA 1 g/d vs. Placebo & & $\begin{array}{l}\text { Cardiac event, Stroke/TIA, } \\
\text { Arrhythmia event, Death }\end{array}$ \\
\hline $\begin{array}{l}\text { ISRCTN41926726, France, } \\
\text { SU.FOL.OM3 }\end{array}$ & ICTRP & $\begin{array}{l}\text { CVD, } \\
\text { existing }\end{array}$ & $\begin{array}{l}2003- \\
2009\end{array}$ & 2400 & $\begin{array}{l}\text { RCT: Fish oil (EPA+DHA) } 0.6 \mathrm{~g} / \mathrm{d} \text { vs. } \\
\text { Placebo }\end{array}$ & & $\begin{array}{l}\text { Cardiac event, Stroke/TIA, } \\
\text { Death }\end{array}$ \\
\hline ISRCTN66664610, UK, MARINA & ICTRP & $\begin{array}{l}\text { CVD, } \\
\text { existing }\end{array}$ & $\begin{array}{l}2008- \\
2010\end{array}$ & 360 & $\begin{array}{l}\text { RCT: Fish oil (EPA+DHA) } 0.45,0.9, \text { or } \\
1.8 \mathrm{~g} / \mathrm{d} \text { vs. Placebo }\end{array}$ & BP/Lipids & \\
\hline NCT00004559, US, FAAT & $\underline{\text { CT.gov }}$ & $\begin{array}{l}\text { CVD, } \\
\text { existing }\end{array}$ & $\begin{array}{l}2000- \\
2005\end{array}$ & nd & $\begin{array}{l}\text { RCT: Fish oil (EPA+DHA) } 4 \text { g/d vs. } \\
\text { Placebo }\end{array}$ & & Arrhythmia event \\
\hline $\begin{array}{l}\text { NCT00597220, Argentinia, } \\
\text { FORWARD }\end{array}$ & CT.gov & $\begin{array}{l}\text { CVD, } \\
\text { existing }\end{array}$ & $\begin{array}{ll}2008- \\
2011\end{array}$ & 1600 & $\begin{array}{l}\text { RCT: Fish oil (EPA+DHA) } 1 \mathrm{~g} / \mathrm{d} \text { vs. } \\
\text { Placebo }\end{array}$ & & Stroke/TIA, Arrhythmia event \\
\hline NCT01422317, Norway, OFAMI & $\underline{\text { CT.gov }}$ & $\begin{array}{l}\text { CVD, } \\
\text { existing }\end{array}$ & $\begin{array}{l}1995- \\
2002\end{array}$ & 300 & $\begin{array}{l}\text { RCT: Fish oil (EPA+DHA) } 3.464 \text { g/d vs. } \\
\text { Placebo }\end{array}$ & Lipids & Cardiac event \\
\hline
\end{tabular}

Table E-1b. Studies in the registry only

\begin{tabular}{|c|c|c|c|c|c|c|c|}
\hline $\begin{array}{l}\text { Study (Registry ID, Locations, } \\
\text { Study Acronym - if available) }\end{array}$ & Registry & Population & $\begin{array}{l}\text { Date } \\
\text { (start/end) }\end{array}$ & $\mathrm{N}$ total ${ }^{*}$ & Study design: Intervention & $\begin{array}{l}\text { Intermediate } \\
\text { Outcomes }\end{array}$ & Clinical Outcomes \\
\hline \multicolumn{8}{|l|}{ In Not In report } \\
\hline CTRI/2012/08/002856, India & $\begin{array}{l}\text { ICTRP } \\
\text { (Clinical } \\
\text { Trial } \\
\text { Registry of } \\
\text { India) }\end{array}$ & Healthy/obese & 2012-? & 60 & $\begin{array}{l}\text { RCT: EPA } 180 \mathrm{mg}+\text { DHA } 120 \mathrm{mg} \text { capsules } \\
\text { vs. EPA } 180 \mathrm{mg}+\text { DHA } 120 \mathrm{mg} \text { capsules } \\
\text { capsules + probiotic capsules vs. probiotic } \\
\text { capsules vs. placebo }\end{array}$ & BP/Lipids & $\begin{array}{l}\text { Cardiac } \\
\text { event/arrhythmia }\end{array}$ \\
\hline NCT00232219, Australia & CT.gov & CVD, existing & $2003-2013$ & 200 & RCT: Fish oil capsules (1.8g/d of EPA+DHA) & & Arrhythmia event \\
\hline NCT02183285, no location listed & CT.gov & Healthy & $2003-2004$ & 203 & $\begin{array}{l}\text { RCT: Multivitamin, Multimineral + Omega-3 } \\
\text { Fatty Acids vs Multivitamin, Multimineral } \\
\text { without Omega-3 Fatty Acids vs placebo }\end{array}$ & BP/Lipids & AEs \\
\hline NCT01350973, no location listed & CT.gov & Dyslipidemia & $2009-2010$ & 611 & $\begin{array}{l}\text { RCT: Omacor } 2 \mathrm{~g} \text {, capsules, orally, once } \\
\text { daily for up to } 12 \text { weeks vs. Omacor } 2 \mathrm{~g} \text {, } \\
\text { capsules, orally, twice daily for up to } 12\end{array}$ & BP/Lipids & AEs \\
\hline
\end{tabular}




\begin{tabular}{|c|c|c|c|c|c|c|c|}
\hline & & & & & $\begin{array}{l}\text { weeks vs. EPA-E, } 0.6 \mathrm{~g} \text {, orally, three-times } \\
\text { daily for up to } 12 \text { weeks. }\end{array}$ & & \\
\hline NCT01350999, no location listed & CT.gov & Dyslipidemia & $2009-2011$ & 503 & $\begin{array}{l}\text { RCT: Omacor } 2 \mathrm{~g} \text {, capsules, orally, once } \\
\text { daily for up to } 52 \text { weeks vs. Omacor } 2 \mathrm{~g}, \\
\text { capsules, orally, twice daily for up to } 52 \\
\text { weeks vs. EPA-E, } 0.6 \mathrm{~g} \text {, orally, three-times } \\
\text { daily for up to } 52 \text { weeks. }\end{array}$ & BP/Lipids, HTN & \\
\hline NCT01048502, US & CT.gov & CVD, existing & $2010-2011$ & 100 & $\begin{array}{l}\text { RCT: Tricor } 145 \text { mg/day vs. Lovaza } 900 \\
\text { mg/day vs. Lovaza } 3600 \text { mg/day vs placebo }\end{array}$ & BP/Lipids & \\
\hline NCT02239198, US & CT.gov & Healthy & $2007-2008$ & 150 & $\begin{array}{l}\text { RCT: Complete nutrition bar with omega-3 } \\
\text { fatty acids vs. Nutrition bar without omega-3 } \\
\text { fatty acids vs. Nutrition bar without added } \\
\text { minerals and vitamins }\end{array}$ & BP/Lipids & \\
\hline NCT00135226, UK & CT.gov & $\mathrm{DM}$ & $2005-2016$ & 15480 & $\begin{array}{l}\text { RCT: Aspirin } 100 \text { mg/day + Omega-3-Ethyl } \\
\text { Esters 1g/day vs. Aspirin } 100 \text { mg/day + } \\
\text { Placebo vs. Placebo + Omega-3-Ethyl Esters } \\
\text { 1g/day vs. Placebo }\end{array}$ & & $\begin{array}{l}\text { Cardiac events, } \\
\text { stroke/TIA }\end{array}$ \\
\hline NCT01810003, Canada & CT.gov & CVD, existing & 2013-2016 & 170 & $\begin{array}{l}\text { RCT: DHA 3g/day (10 wks) vs. EPA 3g/day } \\
\text { (10 wks) vs. placebo }\end{array}$ & BP/Lipids & \\
\hline NCT02210767, US & CT.gov & Healthy & $2014-2016$ & 50 & $\begin{array}{l}\text { RCT: } 2 \text { oz walnuts/day (ALA) vs. fatty acids } \\
\text { not from walnuts vs. low ALA diet }\end{array}$ & BP/Lipids & \\
\hline NCT02285166, Japan & CT.gov & Dyslipidemia & $2014-2019$ & 14000 & $\begin{array}{l}\text { RCT: Lotriga 2-4g/day vs. standard } \\
\text { antihyperlipidemic therapy }\end{array}$ & BP/Lipids, HTN & $\begin{array}{l}\text { Cardiac events, } \\
\text { stroke/TIA, } \\
\text { arrhythmia, PDV, } \\
\text { death }\end{array}$ \\
\hline NCT01841944, Norway & CT.gov & CVD, existing & $2012-2019$ & 1400 & $\begin{array}{l}\text { RCT: Pikasol (1.8 g EPA+DHA)/day vs. } \\
\text { placebo }\end{array}$ & & $\begin{array}{l}\text { Cardiac events, } \\
\text { stroke/TIA, } \\
\text { arrhythmia, death }\end{array}$ \\
\hline NCT01320228, Denmark & CT.gov & Healthy & 2011-2012 & 69 & $\begin{array}{l}\text { RCT: Alli ( } 60 \mathrm{mg} \text { t.i.d) }+5 \mathrm{~g} \text { flaxseed fibers } \\
\text { and } 1200 \mathrm{mg} \text { Ca from Capolac vs. Alli }(60 \mathrm{mg} \\
\text { t.i.d) }+5 \mathrm{~g} \text { flaxseed fibers vs. Alli ( } 60 \mathrm{mg} \text { t.i.d) } \\
+1200 \mathrm{mg} \text { Ca from Capolac vs. Alli ( } 60 \mathrm{mg} \\
\text { t.i.d) + placebo }\end{array}$ & BP/Lipids & \\
\hline NCT02294526, no location listed & $\underline{\text { CT.gov }}$ & $\mathrm{DM}$ & $2012-2013$ & 35 & $\begin{array}{l}\text { RCT: Sardine (100g per day, } 5 \text { days a week) } \\
\text { diet vs no sardine diet }\end{array}$ & BP/Lipids & \\
\hline $\begin{array}{l}\text { NCT01492361, US, Australia, } \\
\text { Canada, India, Netherlands, New } \\
\text { Zealand, Poland, Romania, } \\
\text { Russian Federation, South Africa, } \\
\text { Ukraine }\end{array}$ & CT.gov & CVD, existing & $2011-2017$ & 8000 & $\begin{array}{l}\text { RCT: VASCEPA (icosapent ethyl) vs. } \\
\text { placebo }\end{array}$ & BP/Lipids & $\begin{array}{l}\text { Cardiac events, } \\
\text { stroke/TIA, } \\
\text { arrhythmia, death }\end{array}$ \\
\hline $\begin{array}{l}\text { NCT02104817, US, Argentina, } \\
\text { Australia, Brazil, Canada, Czech } \\
\text { Republic, Denmark, Estonia, } \\
\text { Hungary, Italy, Japan, Korea, } \\
\end{array}$ & CT.gov & $\begin{array}{l}\text { Other (mixed) } \\
\text { CVD high risk }\end{array}$ & $2014-2019$ & 13000 & $\begin{array}{l}\text { RCT: Epanova + statin daily vs. placebo + } \\
\text { statin daily }\end{array}$ & & $\begin{array}{l}\text { Cardiac events, } \\
\text { stroke/TIA, } \\
\text { arrhythmia, death }\end{array}$ \\
\hline
\end{tabular}




\begin{tabular}{|c|c|c|c|c|c|c|c|}
\hline $\begin{array}{l}\text { Latvia, Lithuania, Mexico, } \\
\text { Netherlands, New Zealand, } \\
\text { Poland, Romania, Russian } \\
\text { Federation, South Africa, Taiwan, } \\
\text { Ukraine, United Kingdom }\end{array}$ & & & & & & & \\
\hline NCT02243969, Netherlands & CT.gov & Mixed & 2014-2015 & 72 & $\begin{array}{l}\text { RCT: Flaxseed oil (ALA) 10g/day (12 wks) } \\
\text { vs. placebo }\end{array}$ & BP/Lipids & \\
\hline NCT01169259, US & $\underline{\text { CT.gov }}$ & Mixed & 2010-2017 & 25874 & $\begin{array}{l}\text { RCT: Vitamin D3 } 2000 \text { IU/day + Omacor, } 1 \\
\text { capsule/day vs. Vitamin D3 } 2000 \text { IU/day + } \\
\text { placebo vs. placebo + Omacor, } 1 \\
\text { capsule/day vs. placebo }\end{array}$ & & Cardiac events \\
\hline NCT02271230, US & CT.gov & CVD, existing & $2014-2020$ & 25875 & $\begin{array}{l}\text { RCT: Vitamin D } 2000 \text { IU/day vs. EPA/DHA } \\
\text { 1g/day vs. placebo }\end{array}$ & & Cardiac events \\
\hline NCT01785004, US & CT.gov & Healthy & $2012-2015$ & 600 & $\begin{array}{l}\text { RCT: Vitamin D3 } 2000 \text { IU/day + Omacor, } 1 \\
\text { capsule/day vs. Vitamin D3 } 2000 \text { IU/day + } \\
\text { placebo vs. placebo + Omacor, } 1 \\
\text { capsule/day vs. placebo }\end{array}$ & BP/Lipids & \\
\hline NCT01653678, US & $\underline{\text { CT.gov }}$ & HTN & 2011-2017 & 25875 & $\begin{array}{l}\text { RCT: Vitamin D3 } 2000 \text { IU/day + Omacor, } 1 \\
\text { capsule/day vs. Vitamin D3 } 2000 \text { IU/day + } \\
\text { placebo vs. placebo + Omacor, } 1 \\
\text { capsule/day vs. placebo }\end{array}$ & BP/Lipids, HTN & \\
\hline NCT02178410, US & $\underline{\text { CT.gov }}$ & CVD, existing & 2012-2017 & 25875 & $\begin{array}{l}\text { RCT: Vitamin D3 } 2000 \text { IU/day + Omacor, } 1 \\
\text { capsule/day vs. Vitamin D3 } 2000 \text { IU/day + } \\
\text { placebo vs. placebo + Omacor, } 1 \\
\text { capsule/day vs. placebo }\end{array}$ & & $\begin{array}{l}\text { Cardiac events, } \\
\text { arrhythmia, death }\end{array}$ \\
\hline NCT02155816, US & CT.gov & Healthy & 2014-2014 & 68 & $\begin{array}{l}\text { RCT: Omega } 3(1000 \mathrm{mg} / \text { day) for } 8 \text { wks vs. } \\
\text { Omega } 7 \text { (210mg/day) and Omega } 3 \\
(1000 \mathrm{mg} / \mathrm{day}) \text { for } 8 \text { wks vs. placebo }\end{array}$ & BP/Lipids & \\
\hline NCT00967733, no location listed & $\underline{\text { CT.gov }}$ & CVD, existing & $2009-2009$ & 130 & $\begin{array}{l}\text { RCT: Flaxseed oil (ALA) 2-4 g/day + olive oil } \\
\text { cooking vs. Olive oil pill 1g/day + olive oil } \\
\text { cooking vs. Flaxseed oil (ALA) 2-4 g/day + } \\
\text { sunflower oil cooking vs. Olive oil pill 1g/day } \\
+ \text { sunflower oil cooking }\end{array}$ & BP/Lipids & \\
\hline NCT00422266, India & $\underline{\text { CT.gov }}$ & Dyslipidemia & 2006-2007 & 178 & RCT: Not explicitly described & BP/Lipids & \\
\hline NCT01224249, Denmark & CT.gov & Healthy & $2010-2011$ & 102 & $\begin{array}{l}\text { Obs: Fish and shellfish } 1000 \text { g/week for six } \\
\text { months vs. no comparator }\end{array}$ & BP/Lipids & \\
\hline $\begin{array}{l}\text { ACTRN12607000278437, } \\
\text { Australia }\end{array}$ & ICTRP & Healthy & 2007-? & 400 & $\begin{array}{l}\text { RCT: DHA } 430 \text { mg/EPA } 150 \text { mg QID vs. olive } \\
\text { oil }\end{array}$ & $\mathrm{BP}$ & \\
\hline
\end{tabular}




\begin{tabular}{|c|c|c|c|c|c|c|c|}
\hline JPRN-UMIN000011934, Japan & ICTRP & CVD, existing & $2010-2013$ & 80 & $\begin{array}{l}\text { RCT: EPA } 1800 \mathrm{mg}+\text { statin therapy/day (2 } \\
\text { yrs) vs. Ezetimibe } 10 \mathrm{mg}+\text { statin therapy/day } \\
\text { (2yrs) vs. statin therapy (2yrs) }\end{array}$ & & $\begin{array}{l}\text { Cardiac events, } \\
\text { PVD, death }\end{array}$ \\
\hline JPRN-UMIN000007956, Japan & ICTRP & CVD, existing & 2012-? & 80 & $\begin{array}{l}\text { RCT: EPA } 1800 \text { mg/day + statin therapy vs. } \\
\text { statin therapy }\end{array}$ & BP/Lipids & \\
\hline ISRCTN16448451, UK & ICTRP & CVD, existing & $1998-2002$ & nd & RCT: fish oil + normal diet vs. normal diet & & Arrhythmia \\
\hline ISRCTN24439243, Spain & ICTRP & $\begin{array}{l}\text { Other (mixed) } \\
\text { CVD high risk }\end{array}$ & $2009-2011$ & 250 & $\begin{array}{l}\text { RCT: increased fish consumption + normal } \\
\text { diet vs. normal diet }\end{array}$ & BP/Lipids & \\
\hline RBR-5668v4, Brazil & ICTRP & $\begin{array}{l}\text { Other (mixed) } \\
\text { CVD high risk }\end{array}$ & $2011-2013$ & 87 & $\begin{array}{l}\text { RCT: Omega-3 900my/day + dietary } \\
\text { guidance vs. dietary guidance }\end{array}$ & BP/Lipids & \\
\hline $\begin{array}{l}\text { IRCT2013080514273N1, no } \\
\text { location listed }\end{array}$ & ICTRP & CVD, existing & $2013-2013$ & 60 & RCT: & BP/Lipids & \\
\hline JPRN-UMIN000006416, Japan & ICTRP & CVD, existing & 2009-? & 100 & $\begin{array}{l}\text { RCT: Aspirin100 mg/day vs. EPA ethyl ester } \\
\text { 1800mg/day + Aspirin100mg/day }\end{array}$ & BP/Lipids & \\
\hline JPRN-UMIN000007266, Japan & ICTRP & CVD, existing & 2012-? & 200 & RCT: EPA vs. antiplatelet + statins & & $\begin{array}{l}\text { Cardiac events, } \\
\text { stroke/TIA, PVD, } \\
\text { death }\end{array}$ \\
\hline JPRN-UMIN000012069, Japan & ICTRP & CVD, existing & $2013-2019$ & 3200 & $\begin{array}{l}\text { RCT: EPA } 1800 \text { mg/day + statin therapy vs. } \\
\text { statin therapy }\end{array}$ & & $\begin{array}{l}\text { Cardiac events, } \\
\text { stroke/TIA, PVD, } \\
\text { death }\end{array}$ \\
\hline JPRN-UMIN000016723, Japan & ICTRP & CVD, existing & $2010-?$ & 200 & $\begin{array}{l}\text { RCT: pitavastatin } 2 \text { mg/day + EPA } 1800 \\
\text { mg/day vs. pitavastatin } 2 \text { mg/day }\end{array}$ & & $\begin{array}{l}\text { Cardiac events, } \\
\text { stroke/TIA }\end{array}$ \\
\hline JPRN-UMIN000018056, Japan & ICTRP & Dyslipidemia & $2015-?$ & 40 & $\begin{array}{l}\text { RCT: DHA+EPA } 2 \mathrm{~g} / \mathrm{day} \text { ( } 4 \text { wks) at } 4 \text { wks, } \\
\text { triglycerides }>150 \mathrm{mg} / \mathrm{dl} \text {, dose increased to } \\
4 \mathrm{mg} / \text { day }(8 \text { weeks); triglycerides }<150 \mathrm{mg} / \mathrm{dl} \text {, } \\
\text { does maintained at } 2 \mathrm{mg} / \text { day vs. observation }\end{array}$ & BP/Lipids & Cardiac events \\
\hline JPRN-UMIN000004024, Japan & ICTRP & Dyslipidemia & 2010-? & 100 & RCT: EPA (no other details reported) & BP/Lipids & \\
\hline JPRN-UMIN000012852, Japan & ICTRP & CVD, existing & 2014-? & 100 & $\begin{array}{l}\text { RCT: EPA } 1800 \text { mg/day + statin therapy vs. } \\
\text { statin therapy }\end{array}$ & & $\begin{array}{l}\text { Cardiac events, } \\
\text { stroke/TIA, PVD, } \\
\text { death }\end{array}$ \\
\hline EUCTR2006-006863-22-GB, UK & ICTRP & CVD, existing & 2007-? & 100 & $\begin{array}{l}\text { RCT: Cardiozen } 500 \text { mg vs. placebo (no } \\
\text { other information) }\end{array}$ & & Arrhythmia \\
\hline EUCTR2005-001354-25-GB, UK & ICTRP & CVD, existing & $2005-?$ & 150 & $\begin{array}{l}\text { RCT: Omacor vs. placebo (no other } \\
\text { information) }\end{array}$ & & Arrhythmia \\
\hline EUCTR2005-004969-41-IT, Italy & ICTRP & CVD, existing & $2006-?$ & 266 & $\begin{array}{l}\text { RCT: SEACOR 1000MG vs. placebo (no } \\
\text { other information) }\end{array}$ & & Arrhythmia \\
\hline NCT02103517, China & CT.gov & Healthy & $2014-2015$ & 400 & $\begin{array}{l}\text { RCT: Omega-3 FA 4gm/day (3 mos) vs. } \\
\text { placebo }\end{array}$ & BP/Lipids & \\
\hline JPRN-UMIN000003947, Japan & ICTRP & CVD, existing & 2010-? & 200 & $\begin{array}{l}\text { RCT: EPA } 1800 \text { mg/day + statin therapy vs. } \\
\text { statin therapy }\end{array}$ & & $\begin{array}{l}\text { Cardiac events, } \\
\text { PVD, Death }\end{array}$ \\
\hline JPRN-UMIN000012825, Japan & ICTRP & CVD, existing & $2014-2019$ & 180 & $\begin{array}{l}\text { RCT: Statin vs. Statin + EPA vs. Statin + } \\
\text { EPA + DHA }\end{array}$ & BP/Lipids & \\
\hline
\end{tabular}




\begin{tabular}{|l|l|l|l|l|l|l|}
\hline NCT01723345, Iran & CT.gov & CVD, existing & 2012-2013 & 90 & $\begin{array}{l}\text { RCT: EPA 400 mg + DHA 200 mg 12 h prior } \\
\text { to PCl vs standard treatment }\end{array}$ & Cardiac events \\
\hline
\end{tabular}

Table E-2. Design Details Comparative Studies

\begin{tabular}{|c|c|c|c|c|c|c|}
\hline $\begin{array}{l}\text { Author, year, PMID, } \\
\text { country, trial name }\end{array}$ & $\begin{array}{l}\text { Study Design, study start } \\
\text { date }\end{array}$ & $\begin{array}{l}\text { Funding } \\
\text { source/Conflict of } \\
\text { interest }\end{array}$ & $\begin{array}{l}\text { Duration of } \\
\text { Intervention/ } \\
\text { duration of } \\
\text { washout period }\end{array}$ & Eligibility Criteria & Study Population & $\begin{array}{l}\text { Registration } \\
\text { (prospectivel }^{\text {retrospective)* }}\end{array}$ \\
\hline $\begin{array}{l}\text { Baxheinrich, 2012, } \\
\text { 22894911, Germany }\end{array}$ & $\begin{array}{l}\text { Trial: Randomized Parallel, } \\
2010 \text { (approx.) }\end{array}$ & $\begin{array}{l}\text { Industry funded/No } \\
\text { conflict of interest } \\
\text { (explicitly stated) }\end{array}$ & 6 months & $\begin{array}{l}\text { To be enrolled in the study, subjects } \\
\text { had to meet the diagnosis criteria of } \\
\text { the metabolic syndrome according to } \\
\text { the definition of the International } \\
\text { Diabetes Federation (Table 1). } \\
\text { Exclusion criteria were CVD, severe } \\
\text { illnesses such as renal failure or liver } \\
\text { disease, food allergy or intolerance, } \\
\text { pregnancy or lactation, smoking, } \\
\text { alcohol abuse and insulin therapy or } \\
\text { severe diabetic complications in case } \\
\text { of diagnosed type } 2 \text { diabetes mellitus. }\end{array}$ & $\begin{array}{l}\text { Primary Prevention, } \\
\text { Increased CVD Risk (ie, } \\
\text { diabetes, metabolic } \\
\text { syndrome*, hypertension, } \\
\text { dyslipidemia, or chronic } \\
\text { kidney disease): Diabetes } \\
\text { and/or metabolic } \\
\text { syndrome* }\end{array}$ & \\
\hline
\end{tabular}




\begin{tabular}{|c|c|c|c|c|c|c|}
\hline $\begin{array}{l}\text { Author, year, PMID, } \\
\text { country, trial name }\end{array}$ & $\begin{array}{l}\text { Study Design, study start } \\
\text { date }\end{array}$ & $\begin{array}{l}\text { Funding } \\
\text { source/Conflict of } \\
\text { interest }\end{array}$ & $\begin{array}{l}\text { Duration of } \\
\text { Interventionl } \\
\text { duration of } \\
\text { washout period }\end{array}$ & Eligibility Criteria & Study Population & $\begin{array}{l}\text { Registration } \\
\text { (prospectivel } \\
\text { retrospective)* }\end{array}$ \\
\hline $\begin{array}{l}\text { DRKS00006232 } \\
\text { (Baxheinrich, 2012, } \\
\text { 22894911) }\end{array}$ & $\begin{array}{l}\text { Trial: Randomized Parallel, } \\
2008\end{array}$ & $\begin{array}{l}\text { Industry funded/ } \\
\text { Conflict of interest } \\
\text { stated }\end{array}$ & 6 months & $\begin{array}{l}\text { Inclusion Criteria: } 18-70 \text { years old, } \\
\text { male and female. Participants who } \\
\text { had the following traits of metabolic } \\
\text { syndrome were included: central } \\
\text { obesity (waist circumference } \geq 94 \mathrm{~cm} \\
\text { for men and } \geq 80 \mathrm{~cm} \text { for women) plus } \\
\text { two of the following criteria (i) fasting } \\
\text { serum concentrations of } \\
\text { triacylglycerols } \geq 1.7 \mathrm{mmol} / \mathrm{L} \text {, (ii) } \\
\text { reduced serum } \mathrm{HDL} \text { cholesterol } \\
\text { (<1.03 mmol/L in men; }<1.29 \mathrm{mmol} / \mathrm{L} \\
\text { in women), (iii) elevated blood } \\
\text { pressure (systolic } \geq 130 \text { mmHg; } \\
\text { diastolic } \geq 85 \mathrm{mmHg} \text { ), (iv) fasting } \\
\text { plasma glucose } \geq 6.5 \mathrm{mmol} / \mathrm{L} \\
\text { Exclusion Criteria: } \\
\text { smoking; insulin-dependent diabetes } \\
\text { mellitus; liver, gastrointestinal, or } \\
\text { inflammatory diseases; a history of } \\
\text { cardiovascular events; use of anti- } \\
\text { obesity medications or } \\
\text { antiinflammatory drugs; cancer; } \\
\text { pregnancy or breast-feeding; alcohol } \\
\text { abuse }\end{array}$ & $\begin{array}{l}\text { Primary Prevention, } \\
\text { Increased CVD Risk (ie, } \\
\text { diabetes, metabolic } \\
\text { syndrome*, hypertension, } \\
\text { dyslipidemia, or chronic } \\
\text { kidney disease): elevated } \\
\text { blood pressure (systolic } \\
\geq 130 \mathrm{mmHg} \text {; diastolic } \\
\geq 85 \mathrm{mmHg} \text { ), } \\
\text { triacylglycerols } \geq 1.7 \\
\mathrm{mmol} / \mathrm{L} \text {; reduced serum } \\
\mathrm{HDL} \mathrm{cholesterol} \mathrm{(<1.03} \\
\mathrm{mmol} / \mathrm{L} \text { in men; }<1.29 \\
\mathrm{mmol} / \mathrm{L} \text { in women), }\end{array}$ & Retrospective \\
\hline
\end{tabular}




\begin{tabular}{|c|c|c|c|c|c|c|}
\hline $\begin{array}{l}\text { Author, year, PMID, } \\
\text { country, trial name }\end{array}$ & $\begin{array}{l}\text { Study Design, study start } \\
\text { date }\end{array}$ & $\begin{array}{l}\text { Funding } \\
\text { source/Conflict of } \\
\text { interest }\end{array}$ & $\begin{array}{l}\text { Duration of } \\
\text { Interventionl } \\
\text { duration of } \\
\text { washout period }\end{array}$ & Eligibility Criteria & Study Population & $\begin{array}{l}\text { Registration } \\
\text { (prospectivel } \\
\text { retrospective)* }\end{array}$ \\
\hline $\begin{array}{l}\text { Bosch, 2012, 22686415, } \\
\text { Canada, ORIGIN }\end{array}$ & $\begin{array}{l}\text { Trial: Randomized Factorial } \\
\text { Design, } 2003\end{array}$ & Industry funded & 2 years & $\begin{array}{l}\text { At least } 50 \text { years old; a diagnosis of } \\
\text { diabetes with receipt of no more than } \\
\text { one oral glucose-lowering drug, } \\
\text { impaired glucose tolerance (plasma } \\
\text { glucose level at } 2 \text { hours, }=7.8 \mathrm{mM} \\
\text { [140 mg per deciliter] and }<11.1 \mathrm{mM} \\
\text { [200 mg per deciliter] after a } 75-\mathrm{g} \text { oral } \\
\text { glucose load), or impaired fasting } \\
\text { glucose (range, }=6.1 \mathrm{mM}[110 \mathrm{mg} \text { per } \\
\text { deciliter] to <7.0 mM [126 mg per } \\
\text { deciliter]); a history of myocardial } \\
\text { infarction, stroke, or revascularization; } \\
\text { angina with documented ischemia; a } \\
\text { ratio of urinary albumin to creatinine } \\
\text { of more than } 30 \text { mg per gram; left } \\
\text { ventricular hypertrophy; } 50 \% \text { or more } \\
\text { stenosis of a coronary, carotid, or } \\
\text { lower-limb artery on angiography; or } \\
\text { an ankle brachial index of less than } \\
0.9 . \text { Participants were excluded if they } \\
\text { were unwilling to discontinue use of a } \\
\text { nonstudy preparation of } n 3 \text { fatty } \\
\text { acids, had a locally measured } \\
\text { glycated hemoglobin level of } 9 \% \text { or } \\
\text { more, had undergone coronary-artery } \\
\text { bypass grafting within the previous } 4 \\
\text { years with no intervening } \\
\text { cardiovascular event, had severe } \\
\text { heart failure, or had a cancer that } \\
\text { might affect survival. }\end{array}$ & $\begin{array}{l}\text { Primary Prevention, } \\
\text { Increased CVD Risk (ie, } \\
\text { diabetes, metabolic } \\
\text { syndrome*, hypertension, } \\
\text { dyslipidemia, or chronic } \\
\text { kidney disease): Diabetes } \\
\text { and/or metabolic } \\
\text { syndrome*; Hypertension; } \\
\text { Cardiac disease; } \\
\text { Cerebrovascular disease; } \\
\text { Peripheral vascular } \\
\text { disease; Arrhythmia }\end{array}$ & \\
\hline
\end{tabular}




\begin{tabular}{|c|c|c|c|c|c|c|}
\hline $\begin{array}{l}\text { Author, year, PMID, } \\
\text { country, trial name }\end{array}$ & $\begin{array}{l}\text { Study Design, study start } \\
\text { date }\end{array}$ & $\begin{array}{l}\text { Funding } \\
\text { source/Conflict of } \\
\text { interest }\end{array}$ & $\begin{array}{l}\text { Duration of } \\
\text { Interventionl } \\
\text { duration of } \\
\text { washout period }\end{array}$ & Eligibility Criteria & Study Population & $\begin{array}{l}\text { Registration } \\
\text { (prospectivel } \\
\text { retrospective)* }\end{array}$ \\
\hline $\begin{array}{l}\text { NCT00069784 (Bosch, } \\
2012,22686415)\end{array}$ & $\begin{array}{l}\text { Trial: Randomized Factorial } \\
\text { Design, } 2003\end{array}$ & $\begin{array}{l}\text { Industry } \\
\text { funded/Conflict of } \\
\text { interest stated } \\
\text { (principal } \\
\text { Investigators are } \\
\text { NOT employed by } \\
\text { the organization } \\
\text { sponsoring the } \\
\text { study. }\end{array}$ & 6.2 years & $\begin{array}{l}\text { Ages Eligible for Study: } 50 \text { Years and } \\
\text { older. Genders Eligible for Study: } \\
\text { Both. } \\
\text { Inclusion criteria: } \\
\text { Individuals with IFG and/or IGT, or } \\
\text { early diabetes, as defined below. } \\
\text { Glucose tolerance status was } \\
\text { determined by a } 75 \mathrm{~g} \text { oral glucose } \\
\text { tolerance test (OGTT) that was } \\
\text { performed fasting (ie, no consumption } \\
\text { of food or beverage other than water } \\
\text { for at least } 8 \text { hours) at the time of } \\
\text { screening for all candidates who were } \\
\text { not known to have diabetes. The } \\
\text { qualifying OGTT could be obtained up } \\
\text { to } 4 \text { weeks prior to screening provided } \\
\text { that anti-diabetic therapy (if any) } \\
\text { remained unchanged between the } \\
\text { qualifying OGTT and the screening } \\
\text { visit. Two plasma glucose values } \\
\text { were drawn during the OGTT - a } \\
\text { fasting value (FPG) and a value } \\
\text { drawn two hours after the } 75 \mathrm{~g} \text { oral } \\
\text { glucose load was administered } \\
\text { (postprandial plasma glucose [PPG]). } \\
\text { Impaired glucose tolerance (IGT), } \\
\text { defined as a PPG value } \geq 140 \text { and } \\
<200 \text { mg/dL (ie, } \geq 7.8 \text { and }<11.1 \\
\text { mmol/L), with a FPG }<126 \text { mg/dL ( } 7.0 \\
\text { mmol/L). OR - Impaired fasting } \\
\text { glucose (IFG), defined as an FPG } \\
\geq 110 \text { and }<126 \text { mg/dL ( } \geq 6.1 \text { and }<7 \\
\text { mmol/L), without diabetes mellitus } \\
\text { (PPG must be }<200 \text { mg/dL [11.1 } \\
\text { mmol/L]). OR Early type } 2 \text { diabetes, } \\
\text { defined as a FPG } \geq 126 \text { mg/dL ( } 7.0 \\
\text { mmol/L) or a PPG of } \geq 200 \text { mg/dL } \\
\text { (11.1 mmol/L), or a previous } \\
\text { diagnosis of diabetes, and either: } \\
\text { on no pharmacological treatment } \\
\text { (while ambulatory) for at least } 10 \\
\text { weeks prior to screening, with } \\
\text { screening glycated hemoglobin } \\
<150 \% \text { of the upper limit of normal } \\
\text { (ULN) for the laboratory (eg, }<9 \% \text { if } \\
\text { the ULN is } 6 \% \text { ) } \\
\text { or taking one oral antidiabetic drug } \\
\text { (OAD) from among sulfonylureas }\end{array}$ & $\begin{array}{l}\text { Primary Prevention, } \\
\text { Increased CVD Risk: } \\
\text { Diabetes and/or metabolic } \\
\text { syndrome, Hypertension; } \\
\text { Cardiac disease; } \\
\text { Cerebrovascular disease; } \\
\text { Peripheral vascular } \\
\text { disease; Arrhythmia }\end{array}$ & Retrospective \\
\hline
\end{tabular}




\begin{tabular}{|c|c|c|c|c|c|c|}
\hline $\begin{array}{l}\text { Author, year, PMID, } \\
\text { country, trial name }\end{array}$ & $\begin{array}{l}\text { Study Design, study start } \\
\text { date }\end{array}$ & $\begin{array}{l}\text { Funding } \\
\text { source/Conflict of } \\
\text { interest }\end{array}$ & $\begin{array}{l}\text { Duration of } \\
\text { Interventionl } \\
\text { duration of } \\
\text { washout period }\end{array}$ & Eligibility Criteria & Study Population & $\begin{array}{l}\text { Registration } \\
\text { (prospectivel } \\
\text { retrospective)* }\end{array}$ \\
\hline $\begin{array}{l}\text { Brinton, 2013, 23835245, } \\
\text { US, ANCHOR }\end{array}$ & Trial: Randomized Parallel & Industry funded & 12 weeks & $\begin{array}{l}>18 \text { years of age at high risk for CVD } \\
\text { (patients with clinical coronary heart } \\
\text { disease [CHD] or CHD risk } \\
\text { equivalents [10-year risk 20\%]) as } \\
\text { defined by the National Cholesterol } \\
\text { Education Program Adult Treatment } \\
\text { Panel III (NCEP-ATP III) guidelines. } \\
\text { On stable statin therapy (atorvastatin, } \\
\text { rosuvastatin, or simvastatin with or } \\
\text { without ezetimibe) for } 4 \text { weeks at } \\
\text { doses expected to produce "optimal" } \\
\text { LDLC levels for high-risk patients ( } 40 \\
\text { and }<100 \text { mg/dL). Patients who had } \\
\text { A1c >9.5\% or were being treated with } \\
\text { antidiabetes medication that had not } \\
\text { been stable for } 4 \text { weeks at screening } \\
\text { were excluded from the ANCHOR } \\
\text { study. }\end{array}$ & $\begin{array}{l}\text { Primary Prevention, } \\
\text { Increased CVD Risk (ie, } \\
\text { diabetes, metabolic } \\
\text { syndrome*, hypertension, } \\
\text { dyslipidemia, or chronic } \\
\text { kidney disease) }\end{array}$ & \\
\hline
\end{tabular}




\begin{tabular}{|c|c|c|c|c|c|c|}
\hline $\begin{array}{l}\text { Author, year, PMID, } \\
\text { country, trial name }\end{array}$ & $\begin{array}{l}\text { Study Design, study start } \\
\text { date }\end{array}$ & $\begin{array}{l}\text { Funding } \\
\text { source/Conflict of } \\
\text { interest }\end{array}$ & $\begin{array}{l}\text { Duration of } \\
\text { Interventionl } \\
\text { duration of } \\
\text { washout period }\end{array}$ & Eligibility Criteria & Study Population & $\begin{array}{l}\text { Registration } \\
\text { (prospectivel } \\
\text { retrospective)* }\end{array}$ \\
\hline $\begin{array}{l}\text { NCT01047501 (Brinton, } \\
2013, \\
23835245)\end{array}$ & $\begin{array}{l}\text { Trial: Randomized Parallel, } \\
2009\end{array}$ & $\begin{array}{l}\text { Industry funded/No } \\
\text { Data regarding } \\
\text { conflict of interest }\end{array}$ & 12 weeks & $\begin{array}{l}\text { Inclusion Criteria: Men and women, } \\
\text { ages >18; Fasting triglyceride } \geq 200 \\
\text { mg/dL and }<500 \text { mg/dL; LDL-C (low } \\
\text { density lipoprotein - cholesterol) } \geq 40 \\
\text { mg/dL and }<100 \text { mg/dL; High risk for } \\
\text { Coronary heart disease; On stable } \\
\text { dose of statin (atorvastatin, } \\
\text { rosuvastatin or simvastatin); Provide } \\
\text { written informed consent and } \\
\text { authorization for protected health } \\
\text { information disclosure. Exclusion } \\
\text { Criteria: Women who are pregnant or } \\
\text { lactating, or planning to become } \\
\text { pregnant; Use of non-statin lipid- } \\
\text { altering drugs which cannot be } \\
\text { stopped including fibrates, niacin, fish } \\
\text { oil and other products containing } \\
\text { omega-3 fatty acids or other dietary } \\
\text { supplements with potential lipid- } \\
\text { altering effects; History of bariatric } \\
\text { surgery or currently on weight loss } \\
\text { drugs; Uncontrolled hypertension (BP } \\
>160 / 100) ; \text { HIV infection or on } \\
\text { treatment with HIV-protease } \\
\text { inhibitors, cyclophosphamide,or } \\
\text { isotretinoin; Consumption of more } \\
\text { than } 2 \text { alcoholic beverages per day; } \\
\text { History of cancers (except if been } \\
\text { disease free for }>5 \text { years OR history } \\
\text { was basal or squamous cell skin } \\
\text { cancer); Participation in another } \\
\text { clinical trial involving an } \\
\text { investigational agent in the last } 30 \\
\text { days; Other parameters will be } \\
\text { assessed at the study center to } \\
\text { ensure eligibility for this study. }\end{array}$ & $\begin{array}{l}\text { Primary Prevention, } \\
\text { Increased CVD Risk: }\end{array}$ & Retrospective \\
\hline
\end{tabular}




\begin{tabular}{|c|c|c|c|c|c|c|}
\hline $\begin{array}{l}\text { Author, year, PMID, } \\
\text { country, trial name }\end{array}$ & $\begin{array}{l}\text { Study Design, study start } \\
\text { date }\end{array}$ & $\begin{array}{l}\text { Funding } \\
\text { source/Conflict of } \\
\text { interest }\end{array}$ & $\begin{array}{l}\text { Duration of } \\
\text { Intervention/ } \\
\text { duration of } \\
\text { washout period }\end{array}$ & Eligibility Criteria & Study Population & $\begin{array}{l}\text { Registration } \\
\text { (prospectivel } \\
\text { retrospective)* }\end{array}$ \\
\hline $\begin{array}{l}\text { Brouwer, 2006, } 16772624, \\
\text { Germany, Netherlands, } \\
\text { Sweden, UK, Poland, } \\
\text { Czech Republic, Belgium, } \\
\text { Austria, SOFA trial }\end{array}$ & $\begin{array}{l}\text { Trial: Randomized Parallel, } \\
2001\end{array}$ & $\begin{array}{l}\text { No industry } \\
\text { relationship } \\
\text { reported (funding or } \\
\text { affiliations } \\
\text { reported)/No Data } \\
\text { regarding conflict of } \\
\text { interest }\end{array}$ & 12 months & $\begin{array}{l}\text { Men and women >=18 years old, } \\
\text { experienced at least } 1 \text { true, } \\
\text { confirmed, spontaneous VT or VF in } \\
\text { the preceding year, and either had } \\
\text { and ICD or were about to receive one. } \\
\text { Exclusion: receipt of an ICD for } \\
\text { prophylactic reasons; ICD as a } \\
\text { "bridge" to heart transplantation; } \\
\text { refractory supraventricular arrhythmia } \\
\text { with rapid ventricular rates despite } \\
\text { antiarrhythmic therapy; a projected } \\
\text { life span of <1 year; use of } \\
\text { supplemental omega-3 PUFA during } \\
\text { the past } 3 \text { months or consumption } \\
>8 g \text { of omega-3 PUFAs from fish or } \\
\text { seafood per month (267 mg/d) as } \\
\text { judged by a seafood FFQ; pregnant } \\
\text { women; women of childbearing age } \\
\text { who did not use adequate } \\
\text { contraception, and patients with a } \\
\text { known history of recent drug or } \\
\text { alcohol abuse.. excluded patients with } \\
\text { high baseline omega-3 intake from } \\
\text { supplements and/or foods }\end{array}$ & $\begin{array}{l}\text { Secondary Prevention } \\
\text { (history of CVD event): } \\
\text { Arrhythmia (at least } 1 \\
\text { true, confirmed, } \\
\text { spontaneous VT or VF in } \\
\text { the preceding year, and } \\
\text { either had and ICD or } \\
\text { were about to receive } \\
\text { one.) }\end{array}$ & \\
\hline
\end{tabular}




\begin{tabular}{|c|c|c|c|c|c|c|}
\hline $\begin{array}{l}\text { Author, year, PMID, } \\
\text { country, trial name }\end{array}$ & $\begin{array}{l}\text { Study Design, study start } \\
\text { date }\end{array}$ & $\begin{array}{l}\text { Funding } \\
\text { source/Conflict of } \\
\text { interest }\end{array}$ & $\begin{array}{l}\text { Duration of } \\
\text { Interventionl } \\
\text { duration of } \\
\text { washout period }\end{array}$ & Eligibility Criteria & Study Population & $\begin{array}{l}\text { Registration } \\
\text { (prospectivel } \\
\text { retrospective)* }\end{array}$ \\
\hline $\begin{array}{l}\text { NCT00110838 (Brouwer, } \\
\text { 2006, 16772624) }\end{array}$ & $\begin{array}{l}\text { Trial: Randomized Parallel, } \\
2001\end{array}$ & $\begin{array}{l}\text { No industry } \\
\text { relationship } \\
\text { reported/No Data } \\
\text { regarding conflict of } \\
\text { interest }\end{array}$ & 12 months & $\begin{array}{l}\text { Inclusion Criteria: ICD is capable of } \\
\text { recording ECG strips for at least } 10 \text { of } \\
\text { its (attempted) therapeutic } \\
\text { interventions; } 18 \text { years or older; } \\
\text { written informed consent. Exclusion } \\
\text { Criteria: Primary prophylactic } \\
\text { indication; ICD implantation as a } \\
\text { 'bridge' to heart transplantation; } \\
\text { Refractory supraventricular } \\
\text { arrhythmias with rapid ventricular } \\
\text { rates despite antiarrhythmic therapy; } \\
\text { a projected lifespan of less than } 1 \\
\text { year; participation in another trial } \\
\text { (during or within } 30 \text { days before } \\
\text { SOFA); use of any supplemental n-3 } \\
\text { fatty acid during the last } 3 \text { months; } \\
\text { intake of more than } 8 g \text { of n-3 fatty } \\
\text { acids from fish per month as judged } \\
\text { by a fish frequency questionnaire; } \\
\text { pregnant women and women of } \\
\text { childbearing potential who do not use } \\
\text { adequate contraception; patients } \\
\text { known to have a history of recent } \\
\text { drug or alcohol abuse }\end{array}$ & $\begin{array}{l}\text { Primary Prevention, } \\
\text { Increased CVD Risk: } \\
\text { Arrhythmia }\end{array}$ & Prospective \\
\hline $\begin{array}{l}\text { Damsgaard, 2008, } \\
\text { 18492834, Denmark }\end{array}$ & $\begin{array}{l}\text { Trial: Randomized Factorial } \\
\text { Design, } 2005\end{array}$ & $\begin{array}{l}\text { Industry only } \\
\text { donated materials } \\
\text { (eg, } \\
\text { supplements)/No } \\
\text { conflict of interest } \\
\text { (explicitly stated) }\end{array}$ & 8 weeks & $\begin{array}{l}\text { Healthy males, aged } 18-40 \text { y, with no } \\
\text { chronic diseases, no regular } \\
\text { medication, and no strong allergies } \\
\text { who were smoking }<5 \\
\text { cigarettes/week, exercising } \\
\text { strenuously }<7 \mathrm{~h} / \mathrm{wk} \text {, eating } \\
\text { homemade meals }>5 \mathrm{~d} / \mathrm{wk} \text {, and } \\
\text { consumed butter/margarine/or oil } \\
\text { daily. }\end{array}$ & $\begin{array}{l}\text { Primary Prevention, } \\
\text { Healthy }\end{array}$ & \\
\hline
\end{tabular}




\begin{tabular}{|c|c|c|c|c|c|c|}
\hline $\begin{array}{l}\text { Author, year, PMID, } \\
\text { country, trial name }\end{array}$ & $\begin{array}{l}\text { Study Design, study start } \\
\text { date }\end{array}$ & $\begin{array}{l}\text { Funding } \\
\text { source/Conflict of } \\
\text { interest }\end{array}$ & $\begin{array}{l}\text { Duration of } \\
\text { Intervention/ } \\
\text { duration of } \\
\text { washout period }\end{array}$ & Eligibility Criteria & Study Population & $\begin{array}{l}\text { Registration } \\
\text { (prospectivel } \\
\text { retrospective)* }\end{array}$ \\
\hline $\begin{array}{l}\text { NCT00266292 } \\
\text { (Damsgaard, 2008, } \\
\text { 18492834) }\end{array}$ & $\begin{array}{l}\text { Trial: Randomized Factorial } \\
\text { Design, } 2005\end{array}$ & $\begin{array}{l}\text { No industry } \\
\text { relationship } \\
\text { reported/No Data } \\
\text { regarding conflict of } \\
\text { interest }\end{array}$ & 2 months & $\begin{array}{l}\text { Ages Eligible for Study: } 18 \text { Years to } \\
40 \text { Years ;Genders Eligible for Study: } \\
\text { Male; Accepts Healthy Volunteers: } \\
\text { Yes; Healthy (no chronic diseases } \\
\text { and no regular medications); BMl } \\
>18.5 \text { and }<27.5 \mathrm{~kg} / \mathrm{m} 2 ; \text { Daily use of } \\
\text { fats and home cooking }>5 \text { d/wk; } \\
\text { Heavy exercise }<7 \mathrm{~h} / \mathrm{wk} \text {; Not daily } \\
\text { smokers (<5 cigarets/wk) }\end{array}$ & $\begin{array}{l}\text { Primary Prevention, } \\
\text { Healthy }\end{array}$ & Retrospective \\
\hline $\begin{array}{l}\text { Galan, 2010, 21115589, } \\
\text { France, SU.FOL.OM3 }\end{array}$ & $\begin{array}{l}\text { Trial: Randomized Parallel, } \\
2003\end{array}$ & Industry funded & $\begin{array}{l}\text { Median } 4.7 \text { years } \\
\text { (mean } 4.2, \mathrm{SD} \\
1.0 \text { ) }\end{array}$ & $\begin{array}{l}\text { History of CVD (acute coronary event, } \\
\text { including ACS, or cerebral ischemic } \\
\text { event, excluding TIA, within } 12 \mathrm{mo} \text { ), } \\
45-80 \mathrm{y} \text {. Exclude disease or treatment } \\
\text { that might interfere with metabolism of } \\
\text { homocysteine or } \mathrm{n}-3 \mathrm{FA} \text { (eg, } \\
\text { methotrexate), SCr }>200 \mathrm{mcmol} / \mathrm{L} \text {, } \\
\mathrm{CrCl}<40 \mathrm{ml} / \mathrm{min} \text {. }\end{array}$ & $\begin{array}{l}\text { Secondary Prevention } \\
\text { (history of CVD event): } \\
\text { Cardiac disease } \\
\text { (Coronary event w/in } 12 \\
\text { mo, including MI, ACS or } \\
\text { suspected ACS); } \\
\text { Cerebrovascular disease } \\
\text { (CVA (not TIA)) }\end{array}$ & \\
\hline
\end{tabular}




\begin{tabular}{|c|c|c|c|c|c|c|}
\hline $\begin{array}{l}\text { Author, year, PMID, } \\
\text { country, trial name }\end{array}$ & $\begin{array}{l}\text { Study Design, study start } \\
\text { date }\end{array}$ & $\begin{array}{l}\text { Funding } \\
\text { source/Conflict of } \\
\text { interest }\end{array}$ & $\begin{array}{l}\text { Duration of } \\
\text { Interventionl } \\
\text { duration of } \\
\text { washout period }\end{array}$ & Eligibility Criteria & Study Population & $\begin{array}{l}\text { Registration } \\
\text { (prospectivel } \\
\text { retrospective)* }\end{array}$ \\
\hline $\begin{array}{l}\text { ISRCTN41926726 (Galan, } \\
\text { 2010, } \\
21115589)\end{array}$ & $\begin{array}{l}\text { Trial: Randomized Factorial } \\
\text { Design } 2003\end{array}$ & $\begin{array}{l}\text { Industry funded/ } \\
\text { Conflict of interest } \\
\text { stated }\end{array}$ & nd & $\begin{array}{l}\text { Participant inclusion criteria } \\
\text { 1. Participants should have } \\
\text { experienced a coronary or cerebral } \\
\text { event during } 1 \text { to } 12 \text { months before } \\
\text { baseline. A coronary or cerebral event } \\
\text { is defined as: } \\
\text { a. Myocardial infarction (validated and } \\
\text { documented by a combination of } \\
\text { clinical, enzymatic, or } \\
\text { electrocardiogram [ECG] parameters) } \\
\text { b. Acute coronary syndrome without } \\
\text { necrosis (validated and documented } \\
\text { by a combination of clinical, } \\
\text { enzymatic or ECG parameters) } \\
\text { c. A cerebral vascular ischemic } \\
\text { accident (defined by criteria validated } \\
\text { in epidemiological studies) } \\
\text { 2. The participants should be } 45-80 \\
\text { years at baseline } \\
\text { Exclusion criteria } \\
\text { 1. Age }<45 \text { years or }>80 \text { years } \\
\text { 2. Cardiovascular pathology not well } \\
\text { defined } \\
\text { 3. Patients that are incapable of } \\
\text { understanding the study protocol } \\
\text { 4. Patients with a pathology that might } \\
\text { interfere with homocysteine or } \\
\text { omega-3 fatty acid metabolism, in } \\
\text { particular those that use methotrexate } \\
\text { for the treatment of a cancer or } \\
\text { rheumatoid arthritis and chronic renal } \\
\text { failure (plasma level of creatinine } \\
>200 \mu \text { mol/l or creatinine clearance } \\
<40 \text { ml/min) } \\
5 . \text { Patients with a non-cardiovascular } \\
\text { pathology with a suspected survival } \\
\text { time less than the } 5 \text { years period of } \\
\text { the study (solid cancer, evolved } \\
\text { dementia, leukemia etc.) }\end{array}$ & $\begin{array}{l}\text { Secondary Prevention } \\
\text { (history of CVD event): } \\
\text { Ml, ACS, stroke within a } \\
\text { year }\end{array}$ & Retrospective \\
\hline
\end{tabular}




\begin{tabular}{|c|c|c|c|c|c|c|}
\hline $\begin{array}{l}\text { Author, year, PMID, } \\
\text { country, trial name }\end{array}$ & $\begin{array}{l}\text { Study Design, study start } \\
\text { date }\end{array}$ & $\begin{array}{l}\text { Funding } \\
\text { source/Conflict of } \\
\text { interest }\end{array}$ & $\begin{array}{l}\text { Duration of } \\
\text { Interventionl } \\
\text { duration of } \\
\text { washout period }\end{array}$ & Eligibility Criteria & Study Population & $\begin{array}{l}\text { Registration } \\
\text { (prospectivel } \\
\text { retrospective)* }\end{array}$ \\
\hline $\begin{array}{l}\text { Holman, 2009, 19002433, } \\
\text { UK, AFORRD }\end{array}$ & $\begin{array}{l}\text { Trial: Randomized Factorial } \\
\text { Design, } 2004\end{array}$ & Industry funded & 4 months & $\begin{array}{l}\text { Patients with type } 2 \text { diabetes for at } \\
\text { least } 3 \text { months, aged } 18 \text { years, with } \\
\text { no known CVD events, and not } \\
\text { thought by their general practitioner to } \\
\text { be at high enough CVD risk to require } \\
\text { immediate lipid-lowering therapy. }\end{array}$ & $\begin{array}{l}\text { Primary Prevention, } \\
\text { Increased CVD Risk (ie, } \\
\text { diabetes, metabolic } \\
\text { syndrome*, hypertension, } \\
\text { dyslipidemia, or chronic } \\
\text { kidney disease): Diabetes } \\
\text { and/or metabolic } \\
\text { syndrome* }\end{array}$ & \\
\hline $\begin{array}{l}\text { NCT00141232 and } \\
\text { ISRCTN76737502 } \\
\text { (Holman, 2009, 19002433) }\end{array}$ & $\begin{array}{l}\text { Trial: Randomized Factorial } \\
\text { Design, } 2004\end{array}$ & $\begin{array}{l}\text { Industry funded/No } \\
\text { Data regarding } \\
\text { conflict of interest }\end{array}$ & 1 year & $\begin{array}{l}\text { Aged } 18 \text { years or above; have had } \\
\text { Type } 2 \text { Diabetes for at least } 3 \text { months; } \\
\text { not known to have had a } \\
\text { cardiovascular event; have provided } \\
\text { written informed consent; in UK } \\
\text { general practice. }\end{array}$ & $\begin{array}{l}\text { Primary Prevention, } \\
\text { Increased CVD Risk: } \\
\text { Diabetes and/or metabolic } \\
\text { syndrome }\end{array}$ & Retrospective \\
\hline
\end{tabular}




\begin{tabular}{|c|c|c|c|c|c|c|}
\hline $\begin{array}{l}\text { Author, year, PMID, } \\
\text { country, trial name }\end{array}$ & $\begin{array}{l}\text { Study Design, study start } \\
\text { date }\end{array}$ & $\begin{array}{l}\text { Funding } \\
\text { source/Conflict of } \\
\text { interest }\end{array}$ & $\begin{array}{l}\text { Duration of } \\
\text { Interventionl } \\
\text { duration of } \\
\text { washout period }\end{array}$ & Eligibility Criteria & Study Population & $\begin{array}{l}\text { Registration } \\
\text { (prospectivel } \\
\text { retrospective)* }\end{array}$ \\
\hline $\begin{array}{l}\text { Jones, 2014, 24829493, } \\
\text { Canada, COMIT }\end{array}$ & $\begin{array}{l}\text { Trial: Randomized Cross- } \\
\text { over, } 2010\end{array}$ & $\begin{array}{l}\text { Industry } \\
\text { funded/Conflict of } \\
\text { interest stated (All } \\
\text { authors report } \\
\text { having received } \\
\text { grants and funding } \\
\text { from food } \\
\text { companies) }\end{array}$ & 4 weeks/4 weeks & $\begin{array}{l}\text { Inclusion: any of the following: } \\
\text { triglyceride level (TG) } 1.7 \text { mmol/L, } \\
\text { high density lipoprotein cholesterol } \\
\text { level (HDL) <1 mmol/L (males) or } \\
<1.3 \mathrm{mmol} / \mathrm{L} \text { (females), blood } \\
\text { pressure } 130 \mathrm{mmHg} \text { (systolic) and/or } \\
85 \mathrm{mmHg} \text { (diastolic) and glucose level } \\
5.5 \mathrm{mmol} / \mathrm{L} \text {, waist circumference } 94 \\
\mathrm{~cm} \text { for men and } 80 \mathrm{~cm} \text { for women. } \\
\text { Exclusion: thyroid disease (unless } \\
\text { controlled by medication), diabetes } \\
\text { mellitus, kidney disease, liver } \\
\text { disease, current smokers, or those } \\
\text { consuming more than two alcoholic } \\
\text { drinks per week, or medications } \\
\text { known to affect lipid metabolism or } \\
\text { endothelial function (including aspirin } \\
\text { or other non-steroidal anti- } \\
\text { inflammatory drugs), cholestyramine, } \\
\text { colestipol, niacin, clofibrate, } \\
\text { gemfibrozil, probucol, or 3-hydroxy-3- } \\
\text { methyl-glutaryl-CoA (HMG-CoA) } \\
\text { reductase inhibitors.. At the beginning } \\
\text { of the study, the Adult Treatment } \\
\text { Panel III (ATP III) metabolic syndrome } \\
\text { criteria for waist circumference ( }>102 \\
\mathrm{~cm} \text { for men and }>88 \mathrm{~cm} \text { for women) } \\
\text { were followed [28]. As the trial } \\
\text { progressed, the International } \\
\text { Diabetes Federation (IDF) metabolic } \\
\text { syndrome criteria for waist } \\
\text { circumference ( } 94 \mathrm{~cm} \text { for men and } 80 \\
\text { cm for women) were adopted to } \\
\text { identify individuals in the initial stages } \\
\text { of abdominal obesity who might } \\
\text { benefit from dietary intervention. }\end{array}$ & $\begin{array}{l}\text { Primary Prevention, } \\
\text { Increased CVD Risk (ie, } \\
\text { diabetes, metabolic } \\
\text { syndrome*, hypertension, } \\
\text { dyslipidemia, or chronic } \\
\text { kidney disease): } \\
\text { Hypertension (blood } \\
\text { pressure } 130 \mathrm{mmHg} \\
\text { (systolic) and/or } 85 \mathrm{mmHg} \\
\text { (diastolic)); Dyslipidemia } \\
\text { (TG } 1.7 \mathrm{mmol} / \mathrm{L}, \mathrm{HDL}<1 \\
\mathrm{mmol} / \mathrm{L} \text { (males) or }<1.3 \\
\mathrm{mmol} / \mathrm{L} \text { (females)); } \\
\text { Obesity/Overweight (waist } \\
\text { circumference } 94 \mathrm{~cm} \text { for } \\
\text { men and } 80 \mathrm{~cm} \text { for } \\
\text { women); Other (glucose } \\
\text { level } 5.5 \mathrm{mmol} / \mathrm{L} \text { ) }\end{array}$ & \\
\hline
\end{tabular}




\begin{tabular}{|c|c|c|c|c|c|c|}
\hline $\begin{array}{l}\text { Author, year, PMID, } \\
\text { country, trial name }\end{array}$ & $\begin{array}{l}\text { Study Design, study start } \\
\text { date }\end{array}$ & $\begin{array}{l}\text { Funding } \\
\text { source/Conflict of } \\
\text { interest }\end{array}$ & $\begin{array}{l}\text { Duration of } \\
\text { Interventionl } \\
\text { duration of } \\
\text { washout period }\end{array}$ & Eligibility Criteria & Study Population & $\begin{array}{l}\text { Registration } \\
\text { (prospectivel } \\
\text { retrospective)* }\end{array}$ \\
\hline $\begin{array}{l}\text { NCT01351012 (Jones, } \\
2014,24829493 \text { ) }\end{array}$ & $\begin{array}{l}\text { Trial: Randomized Cross- } \\
\text { over, } 2010\end{array}$ & $\begin{array}{l}\text { No industry } \\
\text { relationship } \\
\text { reported/No Data } \\
\text { regarding conflict of } \\
\text { interest }\end{array}$ & 4 weeks/4 weeks & $\begin{array}{l}\text { Inclusion Criteria: Waist } \\
\text { circumference } \geq 94 \mathrm{~cm} \text { (males) or } \geq 80 \\
\mathrm{~cm} \text { (females); age } 18-65 \text { years; plus } \\
\text { at least one of the following: } \\
\text { Triglycerides } \geq 1.7 \mathrm{mmol} / \mathrm{L} ; \text { High } \\
\text { density lipoprotein (HDL) cholesterol } \\
<1 \mathrm{mmol} / \mathrm{L} \text { (males) or }<1.3 \text { mmol/L } \\
\text { (females); Low density lipoprotein } \\
\text { (LDL) cholesterol } \geq 3.5 \mathrm{mmol} / \mathrm{L} ; \text { Blood } \\
\text { pressure } \geq 130 \mathrm{mmHg} \text { (systolic) } \\
\text { and/or } \geq 85 \mathrm{mmHg} \text { (diastolic); Glucose } \\
\geq 5.5 \mathrm{mmol} / \mathrm{L} \text {. } \\
\text { Exclusion Criteria: Thyroid disease; } \\
\text { Diabetes mellitus; Kidney disease; } \\
\text { Liver disease; Smoking; Heavy } \\
\text { drinking; Use of medication known to } \\
\text { affect lipid metabolism during the last } \\
3 \text { months(cholestyramine, colestipol, } \\
\text { niacin, clofibrate, gemfibrozil, } \\
\text { probucol, HMG CoA reductase } \\
\text { inhibitors). }\end{array}$ & $\begin{array}{l}\text { Primary Prevention, } \\
\text { Increased CVD Risk: } \\
\text { Hypertension; } \\
\text { Dyslipidemia; } \\
\text { Obesity/Overweight }\end{array}$ & Retrospective \\
\hline
\end{tabular}




\begin{tabular}{|c|c|c|c|c|c|c|}
\hline $\begin{array}{l}\text { Author, year, PMID, } \\
\text { country, trial name }\end{array}$ & $\begin{array}{l}\text { Study Design, study start } \\
\text { date }\end{array}$ & $\begin{array}{l}\text { Funding } \\
\text { source/Conflict of } \\
\text { interest }\end{array}$ & $\begin{array}{l}\text { Duration of } \\
\text { Interventionl } \\
\text { duration of } \\
\text { washout period }\end{array}$ & Eligibility Criteria & Study Population & $\begin{array}{l}\text { Registration } \\
\text { (prospectivel } \\
\text { retrospective)* }\end{array}$ \\
\hline $\begin{array}{l}\text { Kastelein, 2014, 24528690, } \\
\text { US, Denmark, Netherlands, } \\
\text { India, Hungary, Ukraine, } \\
\text { Russia, EVOLVE }\end{array}$ & $\begin{array}{l}\text { Trial: Randomized Parallel, } \\
2011\end{array}$ & $\begin{array}{l}\text { Industry } \\
\text { funded/Conflict of } \\
\text { interest stated (The } \\
\text { authors } \\
\text { acknowledge that } \\
\text { they have either } \\
\text { received research } \\
\text { grant funding from, } \\
\text { or are employees } \\
\text { of, or have } \\
\text { ownership in } \\
\text { Omthera } \\
\text { Pharmaceuticals, } \\
\text { Inc, the } \\
\text { manufacturer of the } \\
\text { product studied. } \\
\text { The relationship of } \\
\text { authors Dr } \\
\text { Kastelein, Mr } \\
\text { Machielse, Mr Kling, } \\
\text { and Dr Davidson to } \\
\text { Omthera are } \\
\text { considered } \\
\text { significant according } \\
\text { to the definitions } \\
\text { used by the Food } \\
\text { and Drug } \\
\text { Administration. The } \\
\text { following authors } \\
\text { further disclose that } \\
\text { they have other } \\
\text { modest } \\
\text { relationships with } \\
\text { industry that might } \\
\text { pose a potential } \\
\text { conflict of } \\
\text { interest(s): Dr } \\
\text { Kastelein (Amarin), } \\
\text { Dr Maki (Abbott, } \\
\text { Amarin, DSM, GSK, } \\
\text { Pharmavite, Trygg } \\
\text { Pharma), Dr } \\
\text { Susekov (Abbott, } \\
\text { Actavis, Amarin, } \\
\text { Amgen, } \\
\text { AstraZeneca, } \\
\text { Gedeon-Richter, } \\
\text { Genzyme, KRKA, }\end{array}$ & 12 weeks & $\begin{array}{l}\text { Participants included men and women } \\
\text { (nonpregnant, nonlactating) >=18 } \\
\text { years of age with average serum TG } \\
\text { concentrations >=500 mg/dL but } \\
<2000 \text { mg/dL at screening (1 and } 2 \\
\text { weeks before random assignment) } \\
\text { who were either untreated for } \\
\text { dyslipidemia or were using a stable } \\
\text { (for at least } 6 \text { weeks before the first } \\
\text { qualifying lipid measurement) dosage } \\
\text { of a statin, CAl, or their combination. } \\
\text { Subjects were also required to have a } \\
\text { body mass index (calculated as } \\
\text { weight divided by height squared; } \\
\text { kg/m2) >=20 and be willing to } \\
\text { maintain their customary activity level, } \\
\text { follow the TLC diet with weight } \\
\text { maintenance, and restrict their } \\
\text { consumption of fish to no more than } \\
\text { twice per week throughout the study. } \\
\text { Persons with known lipoprotein lipase } \\
\text { impairment or deficiency, } \\
\text { apolipoprotein (Apo) Cll deficiency, or } \\
\text { familial dysbetalipoproteinemia were } \\
\text { excluded from the study, as were } \\
\text { persons with a history of pancreatitis, } \\
\text { symptomatic gallstone disease } \\
\text { (unless treated with } \\
\text { cholecystectomy), uncontrolled } \\
\text { diabetes (glycosylated hemoglobin } \\
\$ 9 \% \text { ), or cancer in the past } 2 \text { years } \\
\text { (basal cell carcinoma was not } \\
\text { exclusionary). Persons with a recent } \\
\text { history (past } 6 \text { months) of a } \\
\text { cardiovascular event (ie, myocardial } \\
\text { infarction, acute coronary syndrome, } \\
\text { new onset angina, stroke, transient } \\
\text { ischemic attack, or unstable } \\
\text { congestive heart failure that required } \\
\text { a change in treatment); } \\
\text { revascularization procedure; aortic } \\
\text { aneurysm; nephrotic syndrome; or } \\
\text { pulmonary, hepatic, biliary, } \\
\text { gastrointestinal, or immunologic } \\
\text { disease were also excluded. Persons } \\
\text { with uncontrolled hypothyroidism, } \\
\text { thyroid-stimulating hormone }>5 \\
\text { mlU/L, or poorly controlled }\end{array}$ & $\begin{array}{l}\text { Primary Prevention, } \\
\text { Increased CVD Risk (ie, } \\
\text { diabetes, metabolic } \\
\text { syndrome*, hypertension, } \\
\text { dyslipidemia, or chronic } \\
\text { kidney disease): } \\
\text { Dyslipidemia (average } \\
\text { serum TG concentrations } \\
500-2000 \mathrm{mg} / \mathrm{dL} \text { ); } \\
\text { Obesity/Overweight (body } \\
\text { mass index >=20) }\end{array}$ & \\
\hline
\end{tabular}




\begin{tabular}{|c|c|c|c|c|c|c|}
\hline $\begin{array}{l}\text { Author, year, PMID, } \\
\text { country, trial name }\end{array}$ & $\begin{array}{l}\text { Study Design, study start } \\
\text { date }\end{array}$ & $\begin{array}{l}\text { Funding } \\
\text { source/Conflict of } \\
\text { interest }\end{array}$ & $\begin{array}{l}\text { Duration of } \\
\text { Interventionl } \\
\text { duration of } \\
\text { washout period }\end{array}$ & Eligibility Criteria & Study Population & $\begin{array}{l}\text { Registration } \\
\text { (prospectivel } \\
\text { retrospective)* }\end{array}$ \\
\hline $\begin{array}{l}\text { NCT01242527 (Kastelein, } \\
2014,24528690)\end{array}$ & $\begin{array}{l}\text { Trial: Randomized Parallel, } \\
2011\end{array}$ & $\begin{array}{l}\text { Industry funded/ } \\
\text { Conflict of interest } \\
\text { stated }\end{array}$ & 12 weeks & $\begin{array}{l}\text { Inclusion Criteria: } \\
\text { Men or women, >=18 years of age. } \\
\text { Very high serum TG values in the } \\
\text { range >=500 mg/dL and <2000 mg/dL } \\
\text { (>=5.65 mmol/L and <22.60 mmol/L) } \\
\text { Exclusion Criteria: } \\
\text { Allergy or intolerance to omega-3 fatty } \\
\text { acids, omega-3-acid ethyl esters, or } \\
\text { fish. } \\
\text { Known lipoprotein lipase impairment } \\
\text { or deficiency or apolipoprotein C-II } \\
\text { deficiency or familial } \\
\text { dysbetalipoproteinemia. } \\
\text { Unable to discontinue use of omega-3 } \\
\text { drugs/supplements. } \\
\text { Unable to discontinue use of bile acid } \\
\text { sequestrants, fibrates or niacin (other } \\
\text { than niacin-containing vitamins <200 } \\
\text { mg), or any supplement used to alter } \\
\text { lipid metabolism. } \\
\text { Women who are pregnant, lactating, } \\
\text { or planning to become pregnant. } \\
\text { Women of childbearing potential who } \\
\text { are not using acceptable } \\
\text { contraceptive methods. } \\
\text { Use of tamoxifen, estrogens or } \\
\text { progestins that has not been stable } \\
\text { for >4 weeks prior to Visit } 1 . \\
\text { Use of oral or injected corticosteroids } \\
\text { or anabolic steroids. } \\
\text { History of pancreatitis. } \\
\text { History of symptomatic gallstone } \\
\text { disease, unless treated with } \\
\text { cholecystectomy. } \\
\text { Uncontrolled diabetes. } \\
\text { Uncontrolled hypothyroidism or } \\
\text { thyroid stimulating hormone (TSH). } \\
\text { History of cancer (other than basal } \\
\text { cell carcinoma) in the past } 2 \text { years. } \\
\text { Cardiovascular event (i.e., myocardial } \\
\text { infarction, acute coronary syndrome, } \\
\text { new onset angina, stroke, transient } \\
\text { ischemic attack, unstable congestive } \\
\text { heart failure requiring a change in } \\
\text { treatment) or revascularization } \\
\text { procedure within six months prior to } \\
\text { Visit } 1 . \\
\text { Use of anticoagulants (e.g. warfarin }\end{array}$ & $\begin{array}{l}\text { Primary Prevention, } \\
\text { Increased CVD Risk: } \\
\text { Dyslipidemia: serum TG } \\
\text { values in the range }>=500 \\
\mathrm{mg} / \mathrm{dL} \text { and }<2000 \mathrm{mg} / \mathrm{dL} \\
(>=5.65 \mathrm{mmol} / \mathrm{L} \text { and } \\
<22.60 \mathrm{mmol} / \mathrm{L})\end{array}$ & Retrospective \\
\hline
\end{tabular}




\begin{tabular}{|c|c|c|c|c|c|c|}
\hline $\begin{array}{l}\text { Author, year, PMID, } \\
\text { country, trial name }\end{array}$ & $\begin{array}{l}\text { Study Design, study start } \\
\text { date }\end{array}$ & $\begin{array}{l}\text { Funding } \\
\text { source/Conflict of } \\
\text { interest }\end{array}$ & $\begin{array}{l}\text { Duration of } \\
\text { Interventionl } \\
\text { duration of } \\
\text { washout period }\end{array}$ & Eligibility Criteria & Study Population & $\begin{array}{l}\text { Registration } \\
\text { (prospectivel } \\
\text { retrospective)* }\end{array}$ \\
\hline $\begin{array}{l}\text { Kromhout, 2010, 20929341, } \\
\text { Netherlands, DART }\end{array}$ & $\begin{array}{l}\text { Trial: Randomized Factorial } \\
\text { Design, } 2002\end{array}$ & $\begin{array}{l}\text { Industry only } \\
\text { donated materials } \\
\text { (eg, } \\
\text { supplements)/No } \\
\text { conflict of interest } \\
\text { (explicitly stated) }\end{array}$ & 40 months & $\begin{array}{l}\text { Men and women } 60 \text { to } 80 \text { years of } \\
\text { age, who had had a clinical } \\
\text { diagnosed } \mathrm{Ml} \text { up to } 10 \text { years before } \\
\text { randomization. Exclusion criteria: } \\
\text { daily consumption of }<1010 \mathrm{~g} \text { of } \\
\text { margarine, use of } n-3 \text { fatty-acid } \\
\text { supplements, unintended weight loss } \\
\text { of }>5 \mathrm{~kg} \text { in the previous year, and a } \\
\text { diagnosis of cancer with an estimated } \\
\text { life expectancy of }<1 \text { year. }\end{array}$ & $\begin{array}{l}\text { Secondary Prevention } \\
\text { (history of CVD event): } \\
\text { Cardiac disease } \\
\text { (myocardial infarction) }\end{array}$ & \\
\hline $\begin{array}{l}\text { NCT00127452 (Kromhout, } \\
\text { 2010, } \\
\text { 20929341) Alpha Omega }\end{array}$ & $\begin{array}{l}\text { Trial: Randomized Parallel, } \\
2002\end{array}$ & $\begin{array}{l}\text { No industry } \\
\text { relationship } \\
\text { reported/No Data } \\
\text { regarding conflict of } \\
\text { interest }\end{array}$ & 40 months & $\begin{array}{l}\text { Inclusion criteria: Men and women; } \\
\text { Aged } 60 \text { through } 80 \text { y; Verified } \\
\text { clinically diagnosed myocardial } \\
\text { infarction up to } 10 \text { y before } \\
\text { randomization; Written informed } \\
\text { consent. Exclusion criteria: Living in a } \\
\text { nursing home or other institution; } \\
\text { Participation in another scientific } \\
\text { study; Habitual margarine intake }<10 \\
\text { g per day; Habitual fish intake }>150 \mathrm{~g} \\
\text { per day; Habitual alcohol intake }>6 \\
\text { drinks per day; Use of fish oil } \\
\text { capsules or other supplements } \\
\text { containing omega-3 fatty acids; } \\
\text { Presence of cancer with < } 1 \text { y of life } \\
\text { expectancy; Cognitive impairment, as } \\
\text { indicated by the Mini Mental State } \\
\text { Examination (score <= } 21 \text { ); } \\
\text { Unintended weight loss }>5 \text { kg in the } \\
\text { past year; Lack of facilities for cooled } \\
\text { margarine storage at home; Inability } \\
\text { or unwillingness to comply with study } \\
\text { procedures }\end{array}$ & $\begin{array}{l}\text { Secondary Prevention } \\
\text { (history of CVD event): } \\
\text { Cardiac disease (verified } \\
\text { clinically diagnosed } \\
\text { myocardial infarction up to } \\
10 \text { y before } \\
\text { randomization) }\end{array}$ & Retrospective \\
\hline
\end{tabular}




\begin{tabular}{|c|c|c|c|c|c|c|}
\hline $\begin{array}{l}\text { Author, year, PMID, } \\
\text { country, trial name }\end{array}$ & $\begin{array}{l}\text { Study Design, study start } \\
\text { date }\end{array}$ & $\begin{array}{l}\text { Funding } \\
\text { source/Conflict of } \\
\text { interest }\end{array}$ & $\begin{array}{l}\text { Duration of } \\
\text { Interventionl } \\
\text { duration of } \\
\text { washout period }\end{array}$ & Eligibility Criteria & Study Population & $\begin{array}{l}\text { Registration } \\
\text { (prospectivel } \\
\text { retrospective)* }\end{array}$ \\
\hline $\begin{array}{l}\text { Kuhnt 2014, 24553695, } \\
\text { Germany }\end{array}$ & $\begin{array}{l}\text { Trial: Randomized Parallel, } \\
2011\end{array}$ & $\begin{array}{l}\text { No conflict of } \\
\text { interest (explicitly } \\
\text { stated) }\end{array}$ & 8 weeks & $\begin{array}{l}\text { Normolipidemic and normal-weight } \\
\text { (BMI 18-25) individuals were recruited } \\
\text { for } 2 \text { age groups: group I, } 20-35 \mathrm{y} \text {; } \\
\text { and group II } 49-69 \text { y. Older } \\
\text { overweight individuals were recruited } \\
\text { for echium oil (EO) intervention only } \\
\text { (49-69 y; BMI >25 with markers of } \\
\text { metabolic syndrome or BMI >= 30). } \\
\text { Patients with markers of metabolic } \\
\text { syndrome were mainly enlisted from } \\
\text { the diabetes research center. This } \\
\text { subgroup - EO III (older overweight } \\
\text { individuals who were recruited for } \\
\text { echium oil intervention only; } 49-69 \text { y; } \\
\text { BMI >25 with markers of metabolic } \\
\text { syndrome) was not included in this } \\
\text { systematic review. }\end{array}$ & $\begin{array}{l}\text { Primary Prevention, } \\
\text { Healthy }\end{array}$ & \\
\hline $\begin{array}{l}\text { NCT01856179 (Kuhnt, } \\
2014,24553695)\end{array}$ & $\begin{array}{l}\text { Trial: Randomized Parallel, } \\
2011\end{array}$ & $\begin{array}{l}\text { No industry } \\
\text { relationship } \\
\text { reported }\end{array}$ & 56 days & $\begin{array}{l}\text { Inclusion Criteria: healthy subjects, } \\
20-70 \text { years. Exclusion Criteria: } \\
\text { cholesterol lowering drugs; chronic } \\
\text { diseases; pregnancy, lactation; intake } \\
\text { of nutritional supplements. }\end{array}$ & $\begin{array}{l}\text { Primary Prevention, } \\
\text { Healthy }\end{array}$ & Retrospective \\
\hline $\begin{array}{l}\text { Leaf, 2005, 16267249, US, } \\
\text { FAAT }\end{array}$ & $\begin{array}{l}\text { Trial: Randomized Parallel, } \\
1999\end{array}$ & $\begin{array}{l}\text { Industry only } \\
\text { donated materials } \\
\text { (eg, } \\
\text { supplements)/No } \\
\text { Data regarding } \\
\text { conflict of interest }\end{array}$ & 1 year & $\begin{array}{l}\text { Subjects were included who had an } \\
\text { ICD implanted because of a history of } \\
\text { cardiac arrest, sustained ventricular } \\
\text { tachycardia (VT), or syncope with } \\
\text { inducible, sustained VT or ventricular } \\
\text { fibrillation (VF) during } \\
\text { electrophysiologic studies. The } \\
\text { qualifying ICD implantation was } \\
\text { required to have occurred within } 12 \\
\text { months before entry into the study or } \\
\text { if the patient had experienced at least } \\
1 \text { spontaneous ICD event for VT/VF in } \\
\text { the preceding } 12 \text { months.. - }\end{array}$ & $\begin{array}{l}\text { Secondary Prevention } \\
\text { (history of CVD event): } \\
\text { Arrhythmia (ICD } \\
\text { implanted) }\end{array}$ & \\
\hline $\begin{array}{l}\text { NCT00004559 (Leaf, 2005, } \\
\text { 16267249) }\end{array}$ & $\begin{array}{l}\text { Trial: Randomized Parallel, } \\
1999\end{array}$ & $\begin{array}{l}\text { No industry } \\
\text { relationship } \\
\text { reported/No Data } \\
\text { regarding conflict of } \\
\text { interest }\end{array}$ & nd & $\begin{array}{l}\text { Ages Eligible for Study: } 18 \text { Years to } \\
75 \text { Years; Genders Eligible for Study: } \\
\text { Both; Accepts Healthy Volunteers: No }\end{array}$ & $\begin{array}{l}\text { Secondary Prevention } \\
\text { (history of CVD event): } \\
\text { Cardiac disease, } \\
\text { Arrhythmia }\end{array}$ & Prospective \\
\hline
\end{tabular}




\begin{tabular}{|c|c|c|c|c|c|c|}
\hline $\begin{array}{l}\text { Author, year, PMID, } \\
\text { country, trial name }\end{array}$ & $\begin{array}{l}\text { Study Design, study start } \\
\text { date }\end{array}$ & $\begin{array}{l}\text { Funding } \\
\text { source/Conflict of } \\
\text { interest }\end{array}$ & $\begin{array}{l}\text { Duration of } \\
\text { Interventionl } \\
\text { duration of } \\
\text { washout period }\end{array}$ & Eligibility Criteria & Study Population & $\begin{array}{l}\text { Registration } \\
\text { (prospectivel } \\
\text { retrospective)* }\end{array}$ \\
\hline $\begin{array}{l}\text { Macchia, 2013, 23265344, } \\
\text { Italy, Argentina, FORWARD }\end{array}$ & $\begin{array}{l}\text { Trial: Randomized Parallel, } \\
2008\end{array}$ & $\begin{array}{l}\text { Industry funded/No } \\
\text { conflict of interest } \\
\text { (explicitly stated) }\end{array}$ & 12 months & $\begin{array}{l}\text { Patients with previous persistent AF } \\
\text { (>=2 symptomatic episodes of } \\
\text { documented AF in the } 6 \text { months } \\
\text { before randomization, with last } \\
\text { episode occurring within } 3 \text { to } 90 \text { days } \\
\text { before randomization (paroxysmal } \\
\text { AF); or successful electrical or } \\
\text { pharmacological cardioversion for } \\
\text { persistent AF performed within } 3 \text { to } 28 \\
\text { days before randomization. }\end{array}$ & $\begin{array}{l}\text { Secondary Prevention } \\
\text { (history of CVD event): } \\
\text { Arrhythmia }\end{array}$ & \\
\hline $\begin{array}{l}\text { NCT00597220 (Macchia, } \\
\text { 2013, 23265344) }\end{array}$ & $\begin{array}{l}\text { Trial: Randomized Parallel, } \\
2008\end{array}$ & $\begin{array}{l}\text { Industry funded/ No } \\
\text { Data regarding } \\
\text { conflict of interest }\end{array}$ & 12 months & $\begin{array}{l}\text { Inclusion Criteria: Persistent atrial } \\
\text { fibrillation; Age 21+ } \\
\text { Exclusion Criteria: Contraindications } \\
\text { or known hypersensitivity to n-3 } \\
\text { PUFA; Current treatment with n-3 } \\
\text { PUFA for any reason; Heart failure } \\
\text { NYHA class IV; Coronary artery } \\
\text { bypass surgery or valve replacement } \\
\text { within the past } 3 \text { months; Planned } \\
\text { cardiac procedures; Known sick-sinus } \\
\text { syndrome; Diagnosis of Wolff- } \\
\text { Parkinson-White; Clinical significant } \\
\text { valvular etiologies; Presence of } \\
\text { arrhythmia associated with an acute } \\
\text { reversible condition; Advanced } \\
\text { chronic lung disease; } \\
\text { Contraindications for anticoagulation } \\
\text { therapy; Pregnancy or lactation; Any } \\
\text { non cardiac illness associated with a } \\
\text { life expectancy of < } 2 \text { years; } \\
\text { Treatment with any investigational } \\
\text { agent within } 3 \text { month before } \\
\text { randomization; Any condition that in } \\
\text { the opinion of the investigator would } \\
\text { jeopardize the evaluation of efficacy } \\
\text { or safety or be associated with poor } \\
\text { adherence to the protocol }\end{array}$ & $\begin{array}{l}\text { Secondary Prevention } \\
\text { (history of CVD event): } \\
\text { Arrhythmia }\end{array}$ & Prospective \\
\hline
\end{tabular}




\begin{tabular}{|c|c|c|c|c|c|c|}
\hline $\begin{array}{l}\text { Author, year, PMID, } \\
\text { country, trial name }\end{array}$ & $\begin{array}{l}\text { Study Design, study start } \\
\text { date }\end{array}$ & $\begin{array}{l}\text { Funding } \\
\text { source/Conflict of } \\
\text { interest }\end{array}$ & $\begin{array}{l}\text { Duration of } \\
\text { Interventionl } \\
\text { duration of } \\
\text { washout period }\end{array}$ & Eligibility Criteria & Study Population & $\begin{array}{l}\text { Registration } \\
\text { (prospectivel } \\
\text { retrospective)* }\end{array}$ \\
\hline $\begin{array}{l}\text { Maki, 2010, 20451686, US, } \\
\text { COMBOS }\end{array}$ & $\begin{array}{l}\text { Trial: Randomized Parallel, } \\
2005\end{array}$ & Industry funded & 8 weeks & $\begin{array}{l}\text { Eligible patients were men or women } \\
\text { between the ages of } 18 \text { and } 79 \text { years } \\
\text { who had been receiving a stable dose } \\
\text { of a statin for the control of LDL-C } \\
\text { levels for =>8 weeks before screening } \\
\text { and were judged to be in good health } \\
\text { on the basis of a medical history, } \\
\text { physical examination, } \\
\text { electrocardiogram, and laboratory } \\
\text { tests, including serum chemistry, } \\
\text { hematology, and urinalysis. Major } \\
\text { inclusion criteria included a mean } \\
\text { fasting TG level >=200 and }<500 \\
\text { mg/dL, and a mean LDL-C level } \\
\text { below or within } 10 \% \text { of the patient's } \\
\mathrm{NCEP} \mathrm{ATPIII} \mathrm{goal.} \mathrm{Major} \mathrm{exclusion} \\
\text { criteria included poorly controlled } \\
\text { diabetes mellitus (glycosylated } \\
\text { hemoglobin [HbAlc] }>8.0 \% \text { at } \\
\text { screening); history of a cardiovascular } \\
\text { event, a revascularization procedure, } \\
\text { or an aortic aneurysm or resection } \\
\text { within } 6 \text { months of screening; history } \\
\text { of pancreatitis; sensitivity to statins or } \\
\text { omega-3 fatty acids; poorly controlled } \\
\text { hypertension (resting blood pressure } \\
=>160 \text { mm Hg systolic and/or }=>100 \\
\text { mm Hg diastolic at } 2 \text { consecutive } \\
\text { visits); serum creatinine level }=>2.0 \\
\text { mg/dL; serum transaminase } \\
\text { (aspartate aminotransferase IAST] or } \\
\text { alanine aminotransferase [ALT]) }>1.5 \\
\text { times the upper limit of normal (ULN) } \\
\text { ( } 45 \mathrm{U} / \mathrm{L} \text { for ALT, } 31 \mathrm{U} / \mathrm{L} \text { for AST); or } \\
\text { creatine kinase (CK) level }>2 \text { times } \\
\text { the ULN. }\end{array}$ & $\begin{array}{l}\text { Primary Prevention, } \\
\text { Increased CVD Risk (ie, } \\
\text { diabetes, metabolic } \\
\text { syndrome* }{ }^{\star} \text {, hypertension, } \\
\text { dyslipidemia, or chronic } \\
\text { kidney disease): } \\
\text { Dyslipidemia (mean } \\
\text { fasting TG level _>200 } \\
\text { and }<500 \mathrm{mg} / \mathrm{dL} \text {, and a } \\
\text { mean LDL-C level below } \\
\text { or within 10\% of the } \\
\text { patient's NCEP ATP III } \\
\text { goal.) }\end{array}$ & \\
\hline
\end{tabular}




\begin{tabular}{|c|c|c|c|c|c|c|}
\hline $\begin{array}{l}\text { Author, year, PMID, } \\
\text { country, trial name }\end{array}$ & $\begin{array}{l}\text { Study Design, study start } \\
\text { date }\end{array}$ & $\begin{array}{l}\text { Funding } \\
\text { source/Conflict of } \\
\text { interest }\end{array}$ & $\begin{array}{l}\text { Duration of } \\
\text { Interventionl } \\
\text { duration of } \\
\text { washout period }\end{array}$ & Eligibility Criteria & Study Population & $\begin{array}{l}\text { Registration } \\
\text { (prospectivel } \\
\text { retrospective)* }\end{array}$ \\
\hline $\begin{array}{l}\text { NCT00246701 (Maki, 2010, } \\
\text { 20451686) }\end{array}$ & $\begin{array}{l}\text { Trial: Randomized Parallel, } \\
2005\end{array}$ & $\begin{array}{l}\text { Industry funded/ No } \\
\text { Data regarding } \\
\text { conflict of interest }\end{array}$ & 8 weeks & $\begin{array}{l}\text { Inclusion Criteria: Men and women } \\
\text { ages } 18-79 \text { years, inclusive; Current } \\
\text { therapy with a statin drug; Triglyceride } \\
\text { levels between } 200 \text { and } 499 \text { mg/dL; } \\
\text { Normally active and in good health on } \\
\text { the basis of medical history, brief } \\
\text { physical examination, } \\
\text { electrocardiogram, and routine } \\
\text { laboratory tests; Provide written } \\
\text { informed consent and authorization } \\
\text { for protected health information } \\
\text { disclosure } \\
\text { Exclusion Criteria: Sensitivity to statin } \\
\text { drugs or omega-3 fatty acids; } \\
\text { Lipoprotein lipase impairment or apo } \\
\text { C-2 deficiency or type III } \\
\text { hyperlipidemia; Unexplained muscle } \\
\text { pain or weakness; History of } \\
\text { pancreatitis; Recent history of certain } \\
\text { heart, kidney, liver, lung, or } \\
\text { gastrointestinal diseases, or cancer } \\
\text { (except non-melanoma skin cancer); } \\
\text { Poorly controlled diabetes, or } \\
\text { receiving insulin therapy; Pregnant or } \\
\text { lactating females; Women of } \\
\text { childbearing potential who are not } \\
\text { using a medically approved method of } \\
\text { contraception; Use of certain types of } \\
\text { hormones, anticonvulsant drugs, } \\
\text { immunologic drugs, antibiotic, } \\
\text { antifungal and antiviral drugs, and } \\
\text { cardiac drugs; Use of warfarin } \\
\text { (Coumadin) }\end{array}$ & $\begin{array}{l}\text { Primary Prevention, } \\
\text { Increased CVD Risk: } \\
\text { Dyslipidemia }\end{array}$ & Prospective \\
\hline
\end{tabular}




\begin{tabular}{|c|c|c|c|c|c|c|}
\hline $\begin{array}{l}\text { Author, year, PMID, } \\
\text { country, trial name }\end{array}$ & $\begin{array}{l}\text { Study Design, study start } \\
\text { date }\end{array}$ & $\begin{array}{l}\text { Funding } \\
\text { source/Conflict of } \\
\text { interest }\end{array}$ & $\begin{array}{l}\text { Duration of } \\
\text { Interventionl } \\
\text { duration of } \\
\text { washout period }\end{array}$ & Eligibility Criteria & Study Population & $\begin{array}{l}\text { Registration } \\
\text { (prospectivel } \\
\text { retrospective)* }\end{array}$ \\
\hline $\begin{array}{l}\text { Maki, 2013, 23998969, US, } \\
\text { ESPRIT TRIAL }\end{array}$ & $\begin{array}{l}\text { Trial: Randomized Parallel, } \\
2011\end{array}$ & Industry funded & 6 weeks & $\begin{array}{l}\text { Participants included men and non } \\
\text { pregnant, nonlactating women } 18 \\
\text { years of age with fasting triglyceride } \\
\text { (TG) levels } 200 \mathrm{mg} / \mathrm{dL} \text { and }<500 \\
\mathrm{mg} / \mathrm{dL} \text { (after } 4 \text { weeks of the statin/diet } \\
\text { lead-in) and at high risk for a future } \\
\text { cardiovascular event. }\end{array}$ & $\begin{array}{l}\text { Primary Prevention, } \\
\text { Increased CVD Risk (ie, } \\
\text { diabetes, metabolic } \\
\text { syndrome*, hypertension, } \\
\text { dyslipidemia, or chronic } \\
\text { kidney disease): } \\
\text { Dyslipidemia ((TG) levels } \\
200 \mathrm{mg} / \mathrm{dL} \text { and <500 } \\
\mathrm{mg} / \mathrm{dL} \text { ) }\end{array}$ & \\
\hline
\end{tabular}




\begin{tabular}{|c|c|c|c|c|c|c|}
\hline $\begin{array}{l}\text { Author, year, PMID, } \\
\text { country, trial name }\end{array}$ & $\begin{array}{l}\text { Study Design, study start } \\
\text { date }\end{array}$ & $\begin{array}{l}\text { Funding } \\
\text { source/Conflict of } \\
\text { interest }\end{array}$ & $\begin{array}{l}\text { Duration of } \\
\text { Interventionl } \\
\text { duration of } \\
\text { washout period }\end{array}$ & Eligibility Criteria & Study Population & $\begin{array}{l}\text { Registration } \\
\text { (prospectivel } \\
\text { retrospective)* }\end{array}$ \\
\hline $\begin{array}{l}\text { NCT01408303 (Maki, 2013, } \\
\text { 23998969) }\end{array}$ & $\begin{array}{l}\text { Trial: Randomized Parallel, } \\
2011\end{array}$ & Industry funded & 6 weeks & $\begin{array}{l}\text { Inclusion Criteria: } \\
\text { Men or women, } \geq 18 \text { years of age. } \\
\text { Fasting triglyceride (TG) level } \geq 200 \\
\text { mg/dL and <500 mg/dL. The subject } \\
\text { is a high risk for a future } \\
\text { cardiovascular event. The subject is } \\
\text { treated with a statin and at or near } \\
\text { LDL-C goal. } \\
\text { Exclusion Criteria: } \\
\text { Allergy or intolerance to omega-3 fatty } \\
\text { acids and omega-3-acid ethyl esters. } \\
\text { Use of fibrates, bile acid } \\
\text { sequestrants, or niacin or its } \\
\text { analogues (greater than } 200 \text { mg/d) } \\
\text { during screening. Use of simvastatin } \\
80 \text { mg or Vytorin10/80 mg during } \\
\text { screening. Use of any } \\
\text { eicosapentaenoic acid (EPA) or } \\
\text { docosahexaenoic acid (DHA) } \\
\text { products. Use of any supplement for } \\
\text { the purpose of lowering plasma } \\
\text { cholesterol during screening. Use of } \\
\text { weight loss drugs or programs during } \\
\text { screening. Use of erythromycin, } \\
\text { telithromycin, clarithromycin, } \\
\text { cyclosporine, itraconazole, } \\
\text { ketoconazole, protease inhibitors, or } \\
\text { nefazodone during screening. Use of } \\
\text { anticoagulants during screening. Use } \\
\text { of oral or injected corticosteroids } \\
\text { during screening.Use of tamoxifen, } \\
\text { estrogens, progestins, or } \\
\text { testosterone, that has not been stable } \\
\text { for }>4 \text { weeks at Visit } 1 \text {, or is unstable } \\
\text { during screening. Use of }>750 \text { mL/d } \\
\text { grapefruit juice during screening. } \\
\text { Known lipoprotein lipase impairment } \\
\text { or deficiency, or apolipoprotein C-॥l } \\
\text { deficiency or familial } \\
\text { dysbetalipoproteinemia. History of } \\
\text { pancreatitis. Type I diabetes mellitus, } \\
\text { use of insulin, or HbA1c }>10 \% \text { at Visit } \\
1 \text {. Poorly controlled hypertension } \\
\text { Uncontrolled hypothyroidism, or } \\
\text { thyroid stimulating hormone (TSH) } \\
>1.5 x U L N \text { at Visit } 2 . \text { Recent history or } \\
\text { current significant nephrotic }\end{array}$ & $\begin{array}{l}\text { Primary Prevention, } \\
\text { Increased CVD Risk: } \\
\text { Dyslipidemia (Fasting } \\
\text { triglyceride (TG) level } \\
\geq 200 \mathrm{mg} / \mathrm{dL} \text { and }<500 \\
\mathrm{mg} / \mathrm{dL} \text {.) }\end{array}$ & Prospective \\
\hline
\end{tabular}




\begin{tabular}{|c|c|c|c|c|c|c|}
\hline $\begin{array}{l}\text { Author, year, PMID, } \\
\text { country, trial name }\end{array}$ & $\begin{array}{l}\text { Study Design, study start } \\
\text { date }\end{array}$ & $\begin{array}{l}\text { Funding } \\
\text { source/Conflict of } \\
\text { interest }\end{array}$ & $\begin{array}{l}\text { Duration of } \\
\text { Interventionl } \\
\text { duration of } \\
\text { washout period }\end{array}$ & Eligibility Criteria & Study Population & $\begin{array}{l}\text { Registration } \\
\text { (prospectivel } \\
\text { retrospective)* }\end{array}$ \\
\hline $\begin{array}{l}\text { Nodari, 2011, 21844082, } \\
\text { Italy }\end{array}$ & $\begin{array}{l}\text { Trial: Randomized Parallel, } \\
2006\end{array}$ & $\begin{array}{l}\text { No industry } \\
\text { relationship } \\
\text { reported (funding or } \\
\text { affiliations reported) }\end{array}$ & 1 year & $\begin{array}{l}\text { Eligibility was determined at a } \\
\text { screening visit that included medical } \\
\text { history, physical examination, 12-lead } \\
\text { ECG, chest x-ray, and 2-dimensional } \\
\text { Doppler echocardiography, plus } \\
\text { complete blood count, routine } \\
\text { chemistry, thyroid function tests, and } \\
\text { pregnancy test in fertile women. }\end{array}$ & $\begin{array}{l}\text { Primary Prevention, } \\
\text { Increased CVD Risk (ie, } \\
\text { diabetes, metabolic } \\
\text { syndrome }^{\star} \text {, hypertension, } \\
\text { dyslipidemia, or chronic } \\
\text { kidney disease): } \\
\text { Arrhythmia }\end{array}$ & \\
\hline $\begin{array}{l}\text { NCT01198275 (Nodari, } \\
\text { 2011, 21844082) ATRIA }\end{array}$ & $\begin{array}{l}\text { Trial: Randomized Parallel, } \\
2006\end{array}$ & $\begin{array}{l}\text { No industry } \\
\text { relationship } \\
\text { reported/ No Data } \\
\text { regarding conflict of } \\
\text { interest }\end{array}$ & 12 months & $\begin{array}{l}\text { Inclusion Criteria: } \\
\text { persistent Atrial Fibrillation (AF) } \\
\text { lasting > one month history of at least } \\
\text { one AF relapse after previous } \\
\text { electrical or Pharmacological } \\
\text { cardioversion } \\
\text { Exclusion Criteria: } \\
\text { left atrium size }>6 \mathrm{~cm} \text { severe } \\
\text { valvulopathy myocardial infarction } \\
\text { during the previous } 6 \text { months } \\
\text { unstable angina NYHA heart failure } \\
\text { class IV or hemodynamic instability } \\
\text { cardiac surgery during the previous } 3 \\
\text { months significant pulmonary thyroid } \\
\text { and hepatic disease contraindications } \\
\text { to treatment with amiodarone or } \\
\text { RASS inhibitors chronic renal } \\
\text { dysfunction QT > } 480 \text { msec in the } \\
\text { absence of bundle-branch block } \\
\text { bradycardia < } 50 \text { b/min diagnosis of } \\
\text { paroxysmal AF hyperkalemia } \\
\text { pregnancy any disease or other } \\
\text { medical treatment that, in the opinion } \\
\text { of the investigators, could interfere } \\
\text { with the study. }\end{array}$ & $\begin{array}{l}\text { Secondary Prevention } \\
\text { (history of CVD event): } \\
\text { Arrhythmia }\end{array}$ & Retrospective \\
\hline
\end{tabular}




\begin{tabular}{|c|c|c|c|c|c|c|}
\hline $\begin{array}{l}\text { Author, year, PMID, } \\
\text { country, trial name }\end{array}$ & $\begin{array}{l}\text { Study Design, study start } \\
\text { date }\end{array}$ & $\begin{array}{l}\text { Funding } \\
\text { source/Conflict of } \\
\text { interest }\end{array}$ & $\begin{array}{l}\text { Duration of } \\
\text { Interventionl } \\
\text { duration of } \\
\text { washout period }\end{array}$ & Eligibility Criteria & Study Population & $\begin{array}{l}\text { Registration } \\
\text { (prospectivel } \\
\text { retrospective)* }\end{array}$ \\
\hline Raitt, 2005, 15956633, US & $\begin{array}{l}\text { Trial: Randomized Parallel, } \\
2001\end{array}$ & $\begin{array}{l}\text { No industry } \\
\text { relationship } \\
\text { reported (funding or } \\
\text { affiliations reported) }\end{array}$ & 718 days (median) & $\begin{array}{l}\text { Patients were eligible for entry if they } \\
\text { were receiving an implantable } \\
\text { cardioverter defibrillator (ICD) for an } \\
\text { electrocardiogram-documented } \\
\text { episode of sustained ventricular } \\
\text { tachycardia (VT) or ventricular } \\
\text { fibrillation (VF) that was not the result } \\
\text { of acute myocardial infarction or a } \\
\text { reversible cause or who had a } \\
\text { preexisting ICD and had received ICD } \\
\text { therapy for an episode of } \\
\text { electrogramdocumented VT/VF within } \\
\text { the previous } 3 \text { months. }\end{array}$ & $\begin{array}{l}\text { Primary Prevention, } \\
\text { Increased CVD Risk (ie, } \\
\text { diabetes, metabolic } \\
\text { syndrome* }^{*} \text { hypertension, } \\
\text { dyslipidemia, or chronic } \\
\text { kidney disease): } \\
\text { Arrhythmia }\end{array}$ & \\
\hline $\begin{array}{l}\text { NCT00004558 (Raitt, 2005, } \\
\text { 15956633) }\end{array}$ & $\begin{array}{l}\text { Trial: Randomized Parallel, } \\
2000\end{array}$ & No data/no data & nd & $\begin{array}{l}\text { Survivors of VT and VF with an } \\
\text { implantable defibrillator. } 18 \text { Years to } \\
75 \text { Years }\end{array}$ & $\begin{array}{l}\text { Secondary Prevention } \\
\text { (history of CVD event): } \\
\text { Arrhythmia }\end{array}$ & Retrospective \\
\hline $\begin{array}{l}\text { Ras, 2014, 25122648, } \\
\text { Sweden }\end{array}$ & $\begin{array}{l}\text { Trial: Randomized Parallel, } \\
2011\end{array}$ & $\begin{array}{l}\text { Industry } \\
\text { funded/conflict of } \\
\text { interest: Ras, } \\
\text { Demonty, Zebregs, } \\
\text { and Trautwein were } \\
\text { employed by } \\
\text { Unilever Research } \\
\text { and Development at } \\
\text { the time of study } \\
\text { conduct. Unilever } \\
\text { markets food } \\
\text { products enriched } \\
\text { with plant sterols. }\end{array}$ & 4 weeks & $\begin{array}{l}\text { Apparently healthy; aged } 25-75 \mathrm{y} \text {; } \\
\text { fasting TC concentration between } 5 \\
\text { and } 8 \mathrm{mmol} / \mathrm{L} \text {; BMI between } 18 \text { and } \\
30 \mathrm{~kg} / \mathrm{m} 2 ; \text { systolic blood pressure } \\
\text { >=160 } \mathrm{mm} \mathrm{Hg} \text {, diastolic blood } \\
\text { pressure >=90 mm } \mathrm{Hg} \text { and heart rate } \\
\text { between } 50 \text { and } 100 \text { beats/min; no } \\
\text { use of medication that could influence } \\
\text { the study outcomes; no use of } \\
\text { nicotine-containing products; } 10-y \\
\text { cardiovascular disease risk >=10 } \\
\text { according to the Systematic Coronary } \\
\text { Risk Evaluation (SCORE); willing to } \\
\text { comply with the study protocol; and } \\
\text { having signed the informed and } \\
\text { biobank consents }\end{array}$ & $\begin{array}{l}\text { Primary Prevention, } \\
\text { Healthy }\end{array}$ & \\
\hline
\end{tabular}




\begin{tabular}{|c|c|c|c|c|c|c|}
\hline $\begin{array}{l}\text { Author, year, PMID, } \\
\text { country, trial name }\end{array}$ & $\begin{array}{l}\text { Study Design, study start } \\
\text { date }\end{array}$ & $\begin{array}{l}\text { Funding } \\
\text { source/Conflict of } \\
\text { interest }\end{array}$ & $\begin{array}{l}\text { Duration of } \\
\text { Interventionl } \\
\text { duration of } \\
\text { washout period }\end{array}$ & Eligibility Criteria & Study Population & $\begin{array}{l}\text { Registration } \\
\text { (prospectivel } \\
\text { retrospective)* }\end{array}$ \\
\hline $\begin{array}{l}\text { NCT01313988 (Ras, 2015, } \\
\text { 25122648) }\end{array}$ & $\begin{array}{l}\text { Trial: Randomized Parallel, } \\
2011\end{array}$ & $\begin{array}{l}\text { Authors report } \\
\text { industry affiliation }\end{array}$ & 4 weeks & $\begin{array}{l}\text { Inclusion Criteria: Apparently healthy } \\
\text { men and women; Age } \geq 25 \text { and } \leq 75 \\
\text { years old; Body mass index (BMI) } \geq \\
18 \text { and } \leq 30 \text { kg/m2; Total cholesterol } \\
\text { levels at screening } \geq 5.0 \text { and } \leq 8.0 \\
\text { mmol/L; } 10 \text {-year CVD risk equal or } \\
\text { lower than } 10 \% \text { according to } \\
\text { "SCORE"; Blood pressure, heart rate, } \\
\text { hematological parameters, clinical } \\
\text { chemical parameters within normal } \\
\text { reference ranges; Informed consent } \\
\text { and biobank consent signed; Willing } \\
\text { to comply to study protocol during } \\
\text { study; Agreeing to be informed about } \\
\text { medically relevant personal test- } \\
\text { results by a physician; Not smoking; } \\
\text { Accessible veins on the forearm; } \\
\text { Habitually consuming spreads. } \\
\text { Exclusion Criteria: Pregnant or having } \\
\text { the wish to become pregnant, or } \\
\text { lactating; Use of prescribed } \\
\text { medication which may interfere with } \\
\text { study measurements; Use of } \\
\text { antibiotics in the } 3 \text { months before } \\
\text { screening or during the study; Use of } \\
\text { any medically- or self-prescribed diet } \\
\text { with the purpose to reduce weight; } \\
\text { Intolerance for gluten or lactose; } \\
\text { Reported food allergy; Having } \\
\text { bleeding disorders; Recent blood } \\
\text { donation; Excessive alcohol } \\
\text { consumption; Strenuous exercise; } \\
\text { Reported weight change } \geq 10 \% \text { of } \\
\text { body weight or use of prescribed } \\
\text { weight reduction drugs; Recent } \\
\text { participation in another nutritional or } \\
\text { medical trial; Participation in night } \\
\text { shift work. }\end{array}$ & $\begin{array}{l}\text { Primary Prevention, } \\
\text { Healthy }\end{array}$ & Retrospective \\
\hline
\end{tabular}




\begin{tabular}{|c|c|c|c|c|c|c|}
\hline $\begin{array}{l}\text { Author, year, PMID, } \\
\text { country, trial name }\end{array}$ & $\begin{array}{l}\text { Study Design, study start } \\
\text { date }\end{array}$ & $\begin{array}{l}\text { Funding } \\
\text { source/Conflict of } \\
\text { interest }\end{array}$ & $\begin{array}{l}\text { Duration of } \\
\text { Interventionl } \\
\text { duration of } \\
\text { washout period }\end{array}$ & Eligibility Criteria & Study Population & $\begin{array}{l}\text { Registration } \\
\text { (prospectivel } \\
\text { retrospective)* }\end{array}$ \\
\hline $\begin{array}{l}\text { Rauch, 2010, 21060071, } \\
\text { Germany, OMEGA }\end{array}$ & $\begin{array}{l}\text { Trial: Randomized Parallel, } \\
2003\end{array}$ & Industry funded & 1 year & $\begin{array}{l}\text { Minimum age of } 18 \text { who were } \\
\text { admitted to hospital for acute STEMI } \\
\text { or non-STEMI and gave written } \\
\text { informed consent to participate in the } \\
\text { study. }\end{array}$ & $\begin{array}{l}\text { Secondary Prevention } \\
\text { (history of CVD event): } \\
\text { Cardiac disease } \\
\text { (Myocardial infarction) }\end{array}$ & \\
\hline $\begin{array}{l}\text { NCT00251134 (Rauch, } \\
\text { 2010, 21060071) }\end{array}$ & $\begin{array}{l}\text { Trial: Randomized Parallel, } \\
2003\end{array}$ & $\begin{array}{l}\text { Industry funded/No } \\
\text { Data regarding } \\
\text { conflict of interest }\end{array}$ & 12 months & $\begin{array}{l}\text { Inclusion Criteria: Myocardial } \\
\text { infarction 3-14 days before } \\
\text { randomisation (STEMI and NSTEMI), } \\
\text { Ability to take } \Omega \text {-3-FAE or olive oil } \\
\text { without risk, Informed consent } \\
\text { Exclusion Criteria: Premenopausal } \\
\text { women who are not surgically sterile, } \\
\text { who are pregnant or nursing, who are } \\
\text { of child-bearing potential and are not } \\
\text { practising acceptable means of birth } \\
\text { control (pregnancy testing required } \\
\text { before randomisation), Known } \\
\text { hypersensitivity to study medication, } \\
\text { Dislike of fish oil, Haemorrhagic } \\
\text { diathesis, Unwillingness to } \\
\text { discontinue other medications } \\
\text { containing fish oil, Legal incapacity, } \\
\text { History of drug or alcohol abuse } \\
\text { within } 6 \text { months, Any investigational } \\
\text { therapy within one month of signing } \\
\text { informed consent form }\end{array}$ & $\begin{array}{l}\text { Secondary Prevention } \\
\text { (history of CVD event): } \\
\text { Cardiac disease } \\
\text { (Myocardial infarction) }\end{array}$ & Retrospective \\
\hline $\begin{array}{l}\text { Rodriguez-Leyva, 2013, } \\
\text { 24126178, Canada, } \\
\text { FlaxPAD }\end{array}$ & $\begin{array}{l}\text { Trial: Randomized Parallel, } \\
2008\end{array}$ & Industry funded & 6 months & $\begin{array}{l}\text { Patients must be }>40 \text { years old, had } \\
\text { PAD (peripheral artery disease) for }> \\
6 \text { months with ankle brachial index } \\
<0.9 . \text {.. exclusion criteria: inability to } \\
\text { walk, bowel disease, moderate to } \\
\text { severe renal failure, life expectancy } \\
<2 \text { years with high baseline cardiac } \\
\text { risk, allergies to any ingredient in the } \\
\text { study product, patients who plan to } \\
\text { undergo surgery during the course of } \\
\text { the trial, and no more than } 2 \text { fish } \\
\text { meals per week }\end{array}$ & $\begin{array}{l}\text { Primary Prevention, } \\
\text { Increased CVD Risk (ie, } \\
\text { diabetes, metabolic } \\
\text { syndrome*, hypertension, } \\
\text { dyslipidemia, or chronic } \\
\text { kidney disease): } \\
\text { Peripheral vascular } \\
\text { disease (nd) }\end{array}$ & \\
\hline
\end{tabular}




\begin{tabular}{|c|c|c|c|c|c|c|}
\hline $\begin{array}{l}\text { Author, year, PMID, } \\
\text { country, trial name }\end{array}$ & $\begin{array}{l}\text { Study Design, study start } \\
\text { date }\end{array}$ & $\begin{array}{l}\text { Funding } \\
\text { source/Conflict of } \\
\text { interest }\end{array}$ & $\begin{array}{l}\text { Duration of } \\
\text { Interventionl } \\
\text { duration of } \\
\text { washout period }\end{array}$ & Eligibility Criteria & Study Population & $\begin{array}{l}\text { Registration } \\
\text { (prospectivel } \\
\text { retrospective)* }\end{array}$ \\
\hline $\begin{array}{l}\text { NCT00781950 (Rodriguez- } \\
\text { Leyva, 2013, 24126178) }\end{array}$ & $\begin{array}{l}\text { Trial: Randomized Parallel, } \\
2008\end{array}$ & nd & $\begin{array}{l}1 \text { year (originally } 2 \\
\text { years) }\end{array}$ & $\begin{array}{l}\text { Inclusion Criteria: } \\
\text { Subjects with peripheral arterial } \\
\text { disease for more than } 6 \text { months. } \\
\text { Male or female with claudication } \\
\text { secondary to lower extremity } \\
\text { atherosclerotic arterial disease. (with } \\
\text { limited IC but not incapacitated for } \\
\text { walking on the level) confirmed with } \\
\text { ankle/brachial pressures< or = to } 0.9 \\
\text { in one or both legs) or who have had } \\
\text { a previous intervention for peripheral } \\
\text { arterial disease.Over } 40 \text { years old } \\
\text { Able to comply with protocol } \\
\text { requirementsAble to provide informed } \\
\text { consent Subjects taking anti-platelet } \\
\text { therapy medication must be on a } \\
\text { stable dose for } 3 \text { months prior to as } \\
\text { well as during the study.Subjects } \\
\text { taking lipid lowering medication must } \\
\text { be on a stable dose for } 3 \text { months prior } \\
\text { to as well as during the study. } \\
\text { Exclusion Criteria: } \\
\text { Patients with ischemic rest pain in } \\
\text { limbs, ulceration, or gangrene. } \\
\text { At baseline, any condition that } \\
\text { prevents walking on a treadmill. } \\
\text { History of major bleeding. Patients } \\
\text { with bowel disease (including Crohn's } \\
\text { disease, celiac disease, peptic ulcer } \\
\text { disease, irritable bowel syndrome and } \\
\text { diverticulosis). Patients with an } \\
\text { estimated life expectancy less than } 2 \\
\text { years and with high baseline cardiac } \\
\text { risk (post ischemic or diabetic } \\
\text { cardiomyopathy with EF<40\%, } \\
\text { Canadian Cardiovascular Society } \\
\text { Class } 3 \text { or } 4 \text { angina or need for } \\
\text { coronary revascularization } \\
\text { procedures). Moderate to severe } \\
\text { renal failure. Subjects that are on } \\
\text { supplements other that those } \\
\text { prescribed by their clinician for the } \\
\text { entire duration of the study. Fish } \\
\text { limitations (no more than } 2 \text { fish meals } \\
\text { per week) Gluten allergy Subjects } \\
\text { with allergies to any ingredient in the } \\
\text { study product or placebo. Patients }\end{array}$ & $\begin{array}{l}\text { Secondary Prevention } \\
\text { (history of CVD event): } \\
\text { peripheral arterial disease } \\
\text { for more than } 6 \text { months }\end{array}$ & Prospective \\
\hline
\end{tabular}




\begin{tabular}{|c|c|c|c|c|c|c|}
\hline $\begin{array}{l}\text { Author, year, PMID, } \\
\text { country, trial name }\end{array}$ & $\begin{array}{l}\text { Study Design, study start } \\
\text { date }\end{array}$ & $\begin{array}{l}\text { Funding } \\
\text { source/Conflict of } \\
\text { interest }\end{array}$ & $\begin{array}{l}\text { Duration of } \\
\text { Interventionl } \\
\text { duration of } \\
\text { washout period }\end{array}$ & Eligibility Criteria & Study Population & $\begin{array}{l}\text { Registration } \\
\text { (prospectivel } \\
\text { retrospective)* }\end{array}$ \\
\hline $\begin{array}{l}\text { Roncaglioni, 2013, } \\
\text { 23656645, Italy }\end{array}$ & $\begin{array}{l}\text { Trial: Randomized Parallel, } \\
2004\end{array}$ & $\begin{array}{l}\text { No Data on funding } \\
\text { or affiliations/No } \\
\text { Data regarding } \\
\text { conflict of interest }\end{array}$ & median 5 years & $\begin{array}{l}\text { Participants with at least one of the } \\
\text { following: multiple cardiovascular risk } \\
\text { factors, clinical evidence of } \\
\text { atherosclerotic vascular disease, or } \\
\text { any other condition putting the patient } \\
\text { at high cardiovascular risk in opinion } \\
\text { of patient's general practitioner. } \\
\text { multiple cardiovascular risk factors } \\
\text { defined as at least four of the } \\
\text { following(or for diabetic patients, one } \\
\text { of the following): age }>65 \text { years, male } \\
\text { sex, hypertension, } \\
\text { hypercholesterolemia, current } \\
\text { smoker, obesity, family history } \\
\text { cardiovascular disease }\end{array}$ & $\begin{array}{l}\text { Primary Prevention, } \\
\text { Increased CVD Risk (ie, } \\
\text { diabetes, metabolic } \\
\text { syndrome*, hypertension, } \\
\text { dyslipidemia, or chronic } \\
\text { kidney disease) }\end{array}$ & \\
\hline $\begin{array}{l}\text { NCT00317707 } \\
\text { (Roncaglioni, 2013, } \\
\text { 23656645) }\end{array}$ & $\begin{array}{l}\text { Trial: Randomized Parallel, } \\
2004\end{array}$ & $\begin{array}{l}\text { No Data on funding } \\
\text { or affiliations/No } \\
\text { Data regarding } \\
\text { conflict of interest }\end{array}$ & 5 years & $\begin{array}{l}\text { Inclusion Criteria: Multiple risk factors: } \\
\text { diabetes, age => } 65 \text { years, male sex, } \\
\text { hypertension, hypercholesterolemia, } \\
\text { smoking, obesity, family history of } \\
\text { premature cardiovascular disease; } \\
\text { Previous manifestations of } \\
\text { atherosclerotic disease ischemic } \\
\text { stoke, transient ischemic attack [TIA], } \\
\text { peripheral artery disease, previous } \\
\text { arterial revascularisation procedures, } \\
\text { angina pectoris) } \\
\text { Exclusion Criteria: Contraindications } \\
\text { (known allergies to n-3 PUFA) or } \\
\text { indications (previous myocardial } \\
\text { infarction) for the treatment with n-3 } \\
\text { PUFA; Serious comorbidity with an } \\
\text { unfavourable prognosis over the short } \\
\text { term; Expected non compliance over } \\
\text { a long period of time; Pregnancy }\end{array}$ & $\begin{array}{l}\text { Primary Prevention, } \\
\text { Increased CVD Risk: } \\
\text { diabetes, hypertension, } \\
\text { dyslipidemia, obesity }\end{array}$ & Retrospective \\
\hline
\end{tabular}




\begin{tabular}{|c|c|c|c|c|c|c|}
\hline $\begin{array}{l}\text { Author, year, PMID, } \\
\text { country, trial name }\end{array}$ & $\begin{array}{l}\text { Study Design, study start } \\
\text { date }\end{array}$ & $\begin{array}{l}\text { Funding } \\
\text { source/Conflict of } \\
\text { interest }\end{array}$ & $\begin{array}{l}\text { Duration of } \\
\text { Interventionl } \\
\text { duration of } \\
\text { washout period }\end{array}$ & Eligibility Criteria & Study Population & $\begin{array}{l}\text { Registration } \\
\text { (prospectivel } \\
\text { retrospective)* }\end{array}$ \\
\hline $\begin{array}{l}\text { Sanders, 2011, 21865334, } \\
\text { UK, MARINA trial }\end{array}$ & $\begin{array}{l}\text { Trial: Randomized Parallel, } \\
2008\end{array}$ & $\begin{array}{l}\text { Industry only } \\
\text { donated materials } \\
\text { (eg, } \\
\text { supplements)/No } \\
\text { conflict of interest } \\
\text { (explicitly stated) }\end{array}$ & 12 months & $\begin{array}{l}\text { Nonsmokers (confirmed by cotinine } \\
\text { testing) men and women aged } 4570 \\
\text { y. Exclusions: a medical history of } \\
\text { CVD; overall risk of cardiovascular } \\
\text { disease }>20 \% \text { over the next } 10 \mathrm{y} \text {; } \\
\text { cancer (excluding basal cell } \\
\text { carcinoma) in the previous } 5 \mathrm{y} \text {; type } 1 \\
\text { DM; uncontrolled type } 2 \mathrm{DM} \text {; chronic } \\
\text { renal, liver, or inflammatory bowel } \\
\text { disease; history of substance abuse } \\
\text { or alcoholism; pregnancy; weight } \\
\text { change of }>3 \mathrm{~kg} \text { in preceding } 2 \mathrm{mo} \text {; } \\
\text { and BMI }<20 \text { and }>35 \text {. }\end{array}$ & $\begin{array}{l}\text { Primary Prevention, } \\
\text { Healthy }\end{array}$ & \\
\hline
\end{tabular}




\begin{tabular}{|c|c|c|c|c|c|c|}
\hline $\begin{array}{l}\text { Author, year, PMID, } \\
\text { country, trial name }\end{array}$ & $\begin{array}{l}\text { Study Design, study start } \\
\text { date }\end{array}$ & $\begin{array}{l}\text { Funding } \\
\text { source/Conflict of } \\
\text { interest }\end{array}$ & $\begin{array}{l}\text { Duration of } \\
\text { Interventionl } \\
\text { duration of } \\
\text { washout period }\end{array}$ & Eligibility Criteria & Study Population & $\begin{array}{l}\text { Registration } \\
\text { (prospectivel } \\
\text { retrospective)* }\end{array}$ \\
\hline $\begin{array}{l}\text { ISRCTN66664610 } \\
\text { (Sanders, 2011, 21865334) }\end{array}$ & $\begin{array}{l}\text { Trial: Randomized Parallel, } \\
2008\end{array}$ & $\begin{array}{l}\text { No industry } \\
\text { relationship } \\
\text { reported/No Data } \\
\text { regarding conflict of } \\
\text { interest }\end{array}$ & 1 year & $\begin{array}{l}\text { Men and women, aged } 45 \text { - } 70 \text { years } \\
\text { Participant exclusion criteria: } 1 \text {. A } \\
\text { reported history of angina, myocardial } \\
\text { infarction or stroke } 2 \text {. Clinical history } \\
\text { of cancer (excluding basal cell } \\
\text { carcinoma) in the past five years } 3 \text {. } \\
\text { Uncontrolled type } 2 \text { diabetes mellitus } \\
\text { (fasting plasma glucose greater than } \\
7 \text { mmol/L) } 4 \text {. Type } 1 \text { diabetes mellitus } \\
5 \text {. Chronic renal, liver or inflammatory } \\
\text { bowel disease } 6 \text {. Current cigarette } \\
\text { smoker } 7 \text {. History of substance abuse } \\
\text { or alcoholism (previous weekly } \\
\text { alcohol intake greater than } 60 \\
\text { units/men or } 50 \text { units/women) } 8 . \\
\text { Current self-reported weekly alcohol } \\
\text { intake not exceeding } 21 \text { units for } \\
\text { women and } 28 \text { for men } 9 \text {. Currently } \\
\text { pregnant, planning pregnancy or } \\
\text { having had a baby in the last } 12 \\
\text { months (there are no hazards from } \\
\text { the EPA or DHA with regard to } \\
\text { pregnancy outcome) } 10 \text {. Allergy or } \\
\text { intolerance to any component of study } \\
\text { capsules } 11 \text {. Unwilling to follow the } \\
\text { protocol and/or give informed consent } \\
12 \text {. Unwilling to refrain from use of } \\
\text { dietary supplements including other } \\
\text { sources of fish oil (e.g. cod liver oil) } \\
13 \text {. Unwilling to restrict consumption } \\
\text { of oily fish } 14 \text {. Weight change of } \\
\text { greater than } 3 \text { kg in preceding } 2 \\
\text { months } 15 \text {. Body mass index less } \\
\text { than } 20 \text { and greater than } 35 \mathrm{~kg} / \mathrm{m}^{\wedge} 2 \\
16 . \text { Subjects with an overall risk of } \\
\text { cardiovascular disease over the next } \\
\text { ten years of greater than } 20 \% \text { who } \\
\text { have untreated high blood pressure or } \\
\text { raised cholesterol (subjects who are } \\
\text { on stable medication for blood } \\
\text { pressure or serum cholesterol } \\
\text { sstatins] will be included) }\end{array}$ & $\begin{array}{l}\text { Primary Prevention, } \\
\text { Healthy }\end{array}$ & Retrospective \\
\hline
\end{tabular}




\begin{tabular}{|c|c|c|c|c|c|c|}
\hline $\begin{array}{l}\text { Author, year, PMID, } \\
\text { country, trial name }\end{array}$ & $\begin{array}{l}\text { Study Design, study start } \\
\text { date }\end{array}$ & $\begin{array}{l}\text { Funding } \\
\text { source/Conflict of } \\
\text { interest }\end{array}$ & $\begin{array}{l}\text { Duration of } \\
\text { Interventionl } \\
\text { duration of } \\
\text { washout period }\end{array}$ & Eligibility Criteria & Study Population & $\begin{array}{l}\text { Registration } \\
\text { (prospectivel } \\
\text { retrospective)* }\end{array}$ \\
\hline $\begin{array}{l}\text { Tavazzi, 2008, 18757090, } \\
\text { Italy, GISSI-HF }\end{array}$ & $\begin{array}{l}\text { Trial: Randomized Parallel, } \\
2002\end{array}$ & Industry funded & 3.9 years & $\begin{array}{l}\text { Eligible patients were men and } \\
\text { women aged } 18 \text { years or older, with } \\
\text { clinical evidence of heart failure of } \\
\text { any cause that was classified } \\
\text { according to the European Society of } \\
\text { Cardiology (ESC) guidelines as New } \\
\text { York Heart Association (NYHA) class } \\
\text { II IV, provided that they had had their } \\
\text { LVEF measured within } 3 \text { months } \\
\text { before enrolment. When LVEF was } \\
\text { greater than } 40 \% \text {, the patient had to } \\
\text { have been admitted at least once to } \\
\text { hospital for heart failure in the } \\
\text { preceding year to meet the inclusion } \\
\text { criteria. Major exclusion criteria } \\
\text { included specific indication or } \\
\text { contraindication to n-3 PUFA; known } \\
\text { hypersensitivity to study treatments; } \\
\text { presence of any non-cardiac } \\
\text { comorbidity (eg, cancer) that was } \\
\text { unlikely to be compatible with a } \\
\text { sufficiently long follow-up; treatment } \\
\text { with any investigational agent within } 1 \\
\text { month before randomisation; acute } \\
\text { coronary syndrome or } \\
\text { revascularisation procedure within the } \\
\text { preceding } 1 \text { month; planned cardiac } \\
\text { surgery, expected to be done within } 3 \\
\text { months after randomisation; } \\
\text { significant liver disease; and pregnant } \\
\text { or lactating women or women of } \\
\text { childbearing potential who were not } \\
\text { adequately protected against } \\
\text { becoming pregnant.. }\end{array}$ & $\begin{array}{l}\text { Secondary Prevention } \\
\text { (history of CVD event): } \\
\text { Cardiac disease } \\
\text { (symptomatic heart failure } \\
\text { of any cause and with any } \\
\text { level of left ventricular } \\
\text { ejection fraction (LVEF).) }\end{array}$ & \\
\hline
\end{tabular}




\begin{tabular}{|c|c|c|c|c|c|c|}
\hline $\begin{array}{l}\text { Author, year, PMID, } \\
\text { country, trial name }\end{array}$ & $\begin{array}{l}\text { Study Design, study start } \\
\text { date }\end{array}$ & $\begin{array}{l}\text { Funding } \\
\text { source/Conflict of } \\
\text { interest }\end{array}$ & $\begin{array}{l}\text { Duration of } \\
\text { Intervention/ } \\
\text { duration of } \\
\text { washout period }\end{array}$ & Eligibility Criteria & Study Population & $\begin{array}{l}\text { Registration } \\
\text { (prospectivel } \\
\text { retrospective)* }\end{array}$ \\
\hline $\begin{array}{l}\text { NCT00336336 (Tavazzi, } \\
\text { 2008, 18757090) }\end{array}$ & $\begin{array}{l}\text { Trial: Randomized Parallel, } \\
2002\end{array}$ & $\begin{array}{l}\text { No industry } \\
\text { relationship } \\
\text { reported/No Data } \\
\text { regarding conflict of } \\
\text { interest }\end{array}$ & $\begin{array}{l}\text { Time Frame: from } \\
\text { enrollment to } 1252 \\
\text { deaths in R2 arm } \\
\text { E-37 }\end{array}$ & $\begin{array}{l}\text { Clinical evidence of heart failure } \\
\text { according to the European Society of } \\
\text { Cardiology guidelines (New York } \\
\text { Heart Association class II-IV) (32); } \\
\text { Any left ventricular Ejection Fraction } \\
\text { (EF) measured within } 3 \text { months from } \\
\text { enrolment (if EF\% }>40 \% \text {, at least } 1 \\
\text { hospital admission for Congestive } \\
\text { Heart Failure(CHF) in the previous } \\
\text { year); } 18 \text { Years and older; Any } \\
\text { etiology; Informed consent (obtained } \\
\text { before any study specific procedure). } \\
\text { Exclusion Criteria: COMMON } \\
\text { EXCLUSION CRITERIA (R1=n-3 } \\
\text { PUFA vs placebo and } \\
\text { R2=rosuvastatin vs placebo): Acute } \\
\text { Myocardial Infarction, unstable angina } \\
\text { or revascularization procedure within } \\
1 \text { month; planned cardiac surgery, } \\
\text { expected to be performed within } 3 \\
\text { months; congenital or primary valvular } \\
\text { etiology; known hypersensitivity to } \\
\text { study treatments; significant liver } \\
\text { disease; pregnant or lactating women } \\
\text { or women of childbearing potential } \\
\text { who are not protected from pregnancy } \\
\text { by an accepted method of } \\
\text { contraception; any condition that in } \\
\text { the opinion of the investigator would } \\
\text { jeopardize the evaluation of efficacy } \\
\text { or safety or be associated with poor } \\
\text { adherence to the protocol; presence } \\
\text { of any non-cardiac disease (e.g. } \\
\text { cancer) that is likely to significantly } \\
\text { shorten life expectancy; treatment } \\
\text { with any investigational agent within } 1 \\
\text { month before randomization; patients } \\
\text { already on treatment with n-3 PUFA } \\
\text { or statin for whom the prescription is } \\
\text { confirmed. EXCLUSION CRITERIA } \\
\text { FOR R2 (statin hypothesis): current } \\
\text { serum creatinine level >2.5 mg/dL; } \\
\text { current ALT, AST level >1.5 times the } \\
\text { upper normal limit; current CPK upper } \\
\text { normal limits. }\end{array}$ & $\begin{array}{l}\text { Secondary Prevention } \\
\text { (history of CVD event): } \\
\text { Cardiac disease }\end{array}$ & Retrospective \\
\hline
\end{tabular}




\begin{tabular}{|c|c|c|c|c|c|c|}
\hline $\begin{array}{l}\text { Author, year, PMID, } \\
\text { country, trial name }\end{array}$ & $\begin{array}{l}\text { Study Design, study start } \\
\text { date }\end{array}$ & $\begin{array}{l}\text { Funding } \\
\text { source/Conflict of } \\
\text { interest }\end{array}$ & $\begin{array}{l}\text { Duration of } \\
\text { Interventionl } \\
\text { duration of } \\
\text { washout period }\end{array}$ & Eligibility Criteria & Study Population & $\begin{array}{l}\text { Registration } \\
\text { (prospectivel } \\
\text { retrospective)* }\end{array}$ \\
\hline $\begin{array}{l}\text { Vazquez, 2014, 24462043, } \\
\text { Spain }\end{array}$ & $\begin{array}{l}\text { Trial: Randomized Cross- } \\
\text { over, } 2011\end{array}$ & $\begin{array}{l}\text { Industry funded/No } \\
\text { conflict of interest } \\
\text { (explicitly stated) }\end{array}$ & 8 weeks/0 weeks & $\begin{array}{l}\text { Exclusion criteria were the following: } \\
\text { patients taking n-3 LCFA } \\
\text { supplements, fish allergy and positive } \\
\text { antibodies to Anisakis spp., presence } \\
\text { of a body mass index (BMI) } 40 \mathrm{~kg} / \mathrm{m} 2 \text {, } \\
\text { chronic kidney disease, liver failure, } \\
\text { chronic psychopathy, neoplasia or } \\
\text { refusal to participate in the study. }\end{array}$ & $\begin{array}{l}\text { Primary Prevention, } \\
\text { Healthy }\end{array}$ & \\
\hline $\begin{array}{l}\text { NCT01758601 (Vazquez, } \\
\text { 2014, 24462043) WISH- } \\
\text { CARE }\end{array}$ & $\begin{array}{l}\text { Trial: Randomized Cross- } \\
\text { over, } 2010\end{array}$ & $\begin{array}{l}\text { Industry/No Data } \\
\text { regarding conflict of } \\
\text { interest }\end{array}$ & 8 weeks/0 weeks & $\begin{array}{l}\text { Inclusion Criteria: We included adult } \\
\text { patients (18 Years to } 65 \text { Years) with } \\
\text { the metabolic syndrome as defined by } \\
\text { the Third Report of the National } \\
\text { Cholesterol Education Program, Adult } \\
\text { Treatment Panel III. Exclusion } \\
\text { Criteria: Fish allergy and positive } \\
\text { antibodies to Anisakis spp. Morbid } \\
\text { obesity with BMl } \geq 40 \mathrm{~kg} / \mathrm{m} 2 \text {. Chronic } \\
\text { renal failure. Chronic psychopathy. } \\
\text { Neoplasia. Refusal to participate in } \\
\text { the study. }\end{array}$ & $\begin{array}{l}\text { Primary Prevention, } \\
\text { Increased CVD Risk: } \\
\text { Diabetes and/or metabolic } \\
\text { syndrome }\end{array}$ & Retrospective \\
\hline
\end{tabular}




\begin{tabular}{|c|c|c|c|c|c|c|}
\hline $\begin{array}{l}\text { Author, year, PMID, } \\
\text { country, trial name }\end{array}$ & $\begin{array}{l}\text { Study Design, study start } \\
\text { date }\end{array}$ & $\begin{array}{l}\text { Funding } \\
\text { source/Conflict of } \\
\text { interest }\end{array}$ & $\begin{array}{l}\text { Duration of } \\
\text { Interventionl } \\
\text { duration of } \\
\text { washout period }\end{array}$ & Eligibility Criteria & Study Population & $\begin{array}{l}\text { Registration } \\
\text { (prospectivel } \\
\text { retrospective)* }\end{array}$ \\
\hline $\begin{array}{l}\text { Yokoyama, 2007, } \\
\text { 17398308, Japan, JELIS }\end{array}$ & $\begin{array}{l}\text { Trial: Randomized Parallel, } \\
1996\end{array}$ & $\begin{array}{l}\text { Industry } \\
\text { funded/Conflict of } \\
\text { interest stated ('M } \\
\text { Yokoyama received } \\
\text { travel costs from } \\
\text { Mochida } \\
\text { Pharmaceutical Co } \\
\text { Ltd, Tokyo, Japan, } \\
\text { to participate in the } \\
\text { scientific meeting. } \\
\text { Other authors have } \\
\text { no conflicts of } \\
\text { interest.') }\end{array}$ & 5 years & $\begin{array}{l}\text { Inclusion criteria: Total cholesterol } \\
\text { concentration of } 65 \text { mmol/L or } \\
\text { greater, which corresponded to a LDL } \\
\text { cholesterol of } 44 \text { mmol/L or greater. } \\
\text { Exclusion criteria: acute myocardial } \\
\text { infarction within the past } 6 \text { months, } \\
\text { unstable angina pectoris, a history or } \\
\text { complication of serious heart disease } \\
\text { (such as severe arrhythmia, heart } \\
\text { failure, cardiomyopathy, valvular } \\
\text { disease, or congenital disease), } \\
\text { cardiovascular reconstruction within } \\
\text { the past } 6 \text { months, cerebrovascular } \\
\text { disorders within the past } 6 \text { months, } \\
\text { complications of serious hepatic or } \\
\text { renal disease, malignant disease, } \\
\text { uncontrollable diabetes, } \\
\text { hyperlipidaemia due to other } \\
\text { disorders, hyperlipidaemia caused by } \\
\text { drugs such as steroid hormones, } \\
\text { haemorrhage (including haemo philia, } \\
\text { capillary fragility, gastrointestinal } \\
\text { ulcer, urinary tract haemorrhage, } \\
\text { haemoptysis, and vitreous } \\
\text { haemorrhage), haemorrhagic } \\
\text { diathesis, hypersensitivity to the study } \\
\text { drug formulation, patients intention to } \\
\text { undergo surgery, and judgment by the } \\
\text { physician in charge that a patient was } \\
\text { inappropriate for the study. }\end{array}$ & $\begin{array}{l}\text { Primary Prevention, } \\
\text { Increased CVD Risk (ie, } \\
\text { diabetes, metabolic } \\
\text { syndrome }{ }^{*} \text {, hypertension, } \\
\text { dyslipidemia, or chronic } \\
\text { kidney disease): } \\
\text { Dyslipidemia (total } \\
\text { cholesterol concentration } \\
\text { of } 65 \mathrm{mmol} / \mathrm{L} \text { or greater, } \\
\text { which corresponded to a } \\
\text { LDL cholesterol of } 44 \\
\text { mmol/L or greater) }\end{array}$ & \\
\hline
\end{tabular}




\begin{tabular}{|c|c|c|c|c|c|c|}
\hline $\begin{array}{l}\text { Author, year, PMID, } \\
\text { country, trial name }\end{array}$ & $\begin{array}{l}\text { Study Design, study start } \\
\text { date }\end{array}$ & $\begin{array}{l}\text { Funding } \\
\text { source/Conflict of } \\
\text { interest }\end{array}$ & $\begin{array}{l}\text { Duration of } \\
\text { Interventionl } \\
\text { duration of } \\
\text { washout period }\end{array}$ & Eligibility Criteria & Study Population & $\begin{array}{l}\text { Registration } \\
\text { (prospectivel } \\
\text { retrospective)* }\end{array}$ \\
\hline $\begin{array}{l}\text { NCT00231738 (Yokoyama, } \\
2007,17398308 \text { ) }\end{array}$ & $\begin{array}{l}\text { Trial: Randomized Parallel, } \\
1996\end{array}$ & $\begin{array}{l}\text { Industry funded } \\
\text { IAuthors report } \\
\text { industry affiliation }\end{array}$ & nd & $\begin{array}{l}\text { Inclusion Criteria: Age } 40 \text { Years to } 75 \\
\text { Years; Eligible participants had a total } \\
\text { cholesterol level of >=250mg/dL(6.5m } \\
\text { mol/L) at baseline; Hyperlipidemic } \\
\text { patients with serum total cholesterol } \\
\text { of } 250 \mathrm{mg} / \mathrm{dL} \text { or more. (Measurement } \\
\text { of serum total cholesterol); Serum } \\
\text { total cholesterol should be measured } \\
\text { twice at interval of 2-4weeks. A single } \\
\text { measurement is acceptable if the } \\
\text { cholesterol is measured by blood } \\
\text { collection at fasting under strict } \\
\text { compliance with dietary advice after } \\
\text { withdrawal of the antihyperlipemic } \\
\text { drug; (Wash Out) The wash out } \\
\text { period of 4weeks (8 weeks for } \\
\text { probucol) is necessary in patients } \\
\text { under treatment with antihyperlipemic } \\
\text { drug. However, if treatment with the } \\
\text { antihyperlipemic drug was started } \\
\text { within } 6 \text { months of the initiation of the } \\
\text { study, the patient can participate in } \\
\text { the study without the washout period. } \\
\text { Exclusion Criteria: Acute myocardial } \\
\text { infarction occurring within last } 6 \\
\text { months; Unstable angina pectoris; A } \\
\text { history or complication of serious } \\
\text { heart disease(severe arrhythmia, } \\
\text { heart failure, cardiac myopathy, } \\
\text { valvular disease, congenital disease, } \\
\text { etc.); Receiving cardiovascular } \\
\text { reconstruction within last } 6 \text { months; } \\
\text { Cerebrovascular disorders occurring } \\
\text { within last } 6 \text { months; Complication of } \\
\text { serious hepatic disease or renal } \\
\text { disease; Malignant tumor; } \\
\text { Uncontrollable diabetes; } \\
\text { Hyperlipidemia arising from the } \\
\text { following disease: Nephrotic } \\
\text { syndrome, hypothyroidism, Cushing's } \\
\text { syndrome, secondary hyperlipidemia } \\
\text { due to other disease; Hyperlipidemia } \\
\text { due to some drugs such as steroid } \\
\text { hormone; Hemorrhage(hemophilia, } \\
\text { capillary fragility, gastrointestinal } \\
\text { ulcer, urinary tract hemorrhage, } \\
\text { hemoptysis, vitreous hemorrhage, } \\
\text { etc.); Hemorrhagic diathesis; }\end{array}$ & $\begin{array}{l}\text { Primary Prevention, } \\
\text { Increased CVD Risk: } \\
\text { Dyslipidemia }\end{array}$ & Retrospective \\
\hline
\end{tabular}


Table E-3. Design Details: Observational studies

\begin{tabular}{|l|l|l|l|l|l|l|}
\hline $\begin{array}{l}\text { Author, year, } \\
\text { PMID, country }\end{array}$ & Study name & Study Design & $\begin{array}{l}\text { Funding } \\
\text { source/Conflict of } \\
\text { interest }\end{array}$ & $\begin{array}{l}\text { Study start } \\
\text { date(s) }\end{array}$ & $\begin{array}{l}\text { Eligibility Criteria } \\
\text { 22743310, US } \\
\text { (prospectivel } \\
\text { retrospective) }\end{array}$ \\
\hline $\begin{array}{l}\text { Lemaitre, 2012, } \\
\text { Health Study }\end{array}$ & $\begin{array}{l}\text { Cardiovascular } \\
\text { longitudinal study of } \\
\text { intake (eg, FFQ, } \\
\text { biomarker) }\end{array}$ & $\begin{array}{l}\text { Authors report } \\
\text { industry affiliation }\end{array}$ & 1989 & $\begin{array}{l}\text { The cohort consisted of 5201 } \\
\text { noninstitutionalized men and women } \\
\text { aged >=65 y, recruited in 1989 1990, plus } \\
\text { an additional } 687 \text { black participants } \\
\text { recruited in 1992 and 1993. Each paper } \\
\text { excluded participants with their outcome } \\
\text { of interest at baseline. }\end{array}$ & $\begin{array}{l}\text { Primary Prevention, } \\
\text { Healthy }\end{array}$ \\
\hline $\begin{array}{l}\text { NCT00005133 } \\
\text { Lemaitre, 2012, } \\
\text { 22743310, US) }\end{array}$ & $\begin{array}{l}\text { Cardiovascular } \\
\text { Health Study }\end{array}$ & $\begin{array}{l}\text { Prospective, } \\
\text { longitudinal study of } \\
\text { intake (eg, FFQ, } \\
\text { biomarker) }\end{array}$ & nd & 1988 & mend and women 65 years and older & $\begin{array}{l}\text { Primary Prevention, } \\
\text { Healthy }\end{array}$ \\
\hline
\end{tabular}

${ }^{*}$ Prospective $=$ First received date within 30 days of start date.

Table E-4: Outcomes Observational Studies

\begin{tabular}{|l|l|l|l|l|}
\hline $\begin{array}{l}\text { Study name, Date, PMID, } \\
\text { Registry number }\end{array}$ & $\begin{array}{l}\text { N record/N } \\
\text { publication }\end{array}$ & Outcome & In papers (timepoint) & $\begin{array}{l}\text { In Registry Record } \\
\text { (timepoint) }\end{array}$ \\
\hline $\begin{array}{l}\text { Lemaitre, 2012, 22743310 } \\
\text { NCT00005133 }\end{array}$ & nd/3941 & Atrial fibrillation & 16 years \\
\hline & & Sudden cardiac death & 16 years & 16 years \\
\hline & & Total CHD & 16 years & 11 years \\
\hline & & Congestive heart failure & 16 years & 11 years \\
\hline & & Myocardial infarction & 16 years & 11 years \\
\hline & Stroke (total) & 16 years & 16 years \\
\hline & Stroke, hemorrhagic & 16 years & 16 years \\
\hline & Stroke, ischemic & & \\
\hline
\end{tabular}


Table E-5: Baselines, Comparative Studies

\begin{tabular}{|c|c|c|c|c|c|c|c|c|c|c|c|c|c|}
\hline $\begin{array}{l}\text { Author, year, } \\
\text { PMID }\end{array}$ & Arm (N) & $\begin{array}{l}\text { Male } \\
\%\end{array}$ & Race \% & $\begin{array}{l}\text { Age } \\
\text { mean } \\
\text { years }\end{array}$ & $\begin{array}{l}\text { SBP } \\
\text { mean } \\
(\mathrm{SD}) \\
\mathrm{mmHg}\end{array}$ & $\begin{array}{l}\text { DBP } \\
\text { mean } \\
(\mathrm{SD}) \\
\mathrm{mmHg}\end{array}$ & $\begin{array}{l}\text { MAP } \\
\text { mean } \\
\text { (SD) } \\
\mathrm{mmHg}\end{array}$ & $\begin{array}{l}\text { Total } \\
\text { Cholesterol } \\
\text { mean (SD) } \\
\text { mg/dL } \\
\text { [mmol/L] }\end{array}$ & $\begin{array}{l}\mathrm{LDL} \\
\text { mean } \\
(\mathrm{SD}) \\
\mathrm{mg} / \mathrm{dL} \\
{[\mathrm{mmol} / \mathrm{L}]}\end{array}$ & $\begin{array}{l}\mathrm{HDL} \\
\text { mean } \\
(\mathrm{SD}) \\
\mathrm{mg} / \mathrm{dL} \\
{[\mathrm{mmol} / \mathrm{L}]}\end{array}$ & $\begin{array}{l}\text { Triglycerides } \\
\text { mean (SD) } \\
\mathrm{mg} / \mathrm{dL} \\
{[\mathrm{mmol} / \mathrm{L}]}\end{array}$ & $\begin{array}{l}\text { BMI mean } \\
\text { (SD) } \\
\mathrm{Kg} / \mathrm{m} 2\end{array}$ & $\begin{array}{l}\text { Do they } \\
\text { match } \\
\text { where } \\
\text { there is } \\
\text { data }\end{array}$ \\
\hline \multirow[t]{4}{*}{$\begin{array}{l}\text { Kastelein } 2014 \\
24528690\end{array}$} & $\begin{array}{l}\text { Placebo [olive oil] } \\
\text { (98) }\end{array}$ & 77.8 & $\begin{array}{l}96 \text { white, } \\
4 \text { Asian, } \\
6.1 \\
\text { Hispanic }\end{array}$ & $\begin{array}{l}50.8 \\
(10.6)\end{array}$ & $\begin{array}{l}130.4 \\
(12.1)\end{array}$ & $\begin{array}{l}80.5 \\
(6.2)\end{array}$ & & $\begin{array}{l}\text { median } 246 \\
\text { (range 135, } \\
409 \text { ) }\end{array}$ & $\begin{array}{l}\text { median } \\
78.2 \\
\text { (range } \\
22.7, \\
161 \text { ) } \\
\end{array}$ & $\begin{array}{l}\text { median } \\
28.7 \\
\text { (range } \\
14,60 \text { ) }\end{array}$ & $\begin{array}{l}\text { median } 682 \\
\text { (range 418, } \\
2007 \text { ) }\end{array}$ & $30.4(4.3)$ & \\
\hline & $\begin{array}{l}\text { "Fish oil" } \\
\text { (DHA+EPA) } \\
\text { [Omega3 } 2 \text { g/d; } \\
\text { olive oil } 2 \text { g/d] (99) }\end{array}$ & 80.0 & $\begin{array}{l}93 \text { white, } \\
5 \text { Asian, } \\
8 \\
\text { Hispanic, } \\
2 \text { other }\end{array}$ & $\begin{array}{l}51.1 \\
(9.8)\end{array}$ & $\begin{array}{l}130.1 \\
(12.4)\end{array}$ & $\begin{array}{l}80.9 \\
(7.7)\end{array}$ & & $\begin{array}{l}\text { Median } 241 \\
\text { (range 131, } \\
542 \text { ) }\end{array}$ & $\begin{array}{l}\text { median } \\
77.3 \\
\text { (range } \\
19.7, \\
182 \text { ) }\end{array}$ & $\begin{array}{l}\text { median } \\
27.3 \\
\text { (range } \\
13.3, \\
47.3 \text { ) }\end{array}$ & $\begin{array}{l}\text { median } 717 \\
\text { (range } 415, \\
1578)\end{array}$ & $31.4(4.8)$ & \\
\hline & $\begin{array}{l}\text { "Fish oil" } \\
\text { (DHA+EPA) } \\
\text { [Omega3 } 3 \mathrm{~g} / \mathrm{d} \text {, } \\
\text { olive oil } 1 \mathrm{~g} / \mathrm{d}] \text { (97) }\end{array}$ & 78.2 & $\begin{array}{l}91.1 \\
\text { white, } 1 \\
\text { black, } 5.9 \\
\text { Asian, } 4 \\
\text { Hispanic, } \\
2 \text { other }\end{array}$ & $\begin{array}{l}51.2 \\
(8.8)\end{array}$ & $\begin{array}{l}129.2 \\
(11.1)\end{array}$ & $\begin{array}{l}81.1 \\
(7.5)\end{array}$ & & $\begin{array}{l}\text { median } 244 \\
\text { (range 151, } \\
641 \text { ) }\end{array}$ & $\begin{array}{l}\text { median } \\
81.0 \\
\text { (range } \\
19.7, \\
213 \text { ) }\end{array}$ & $\begin{array}{l}\text { median } \\
28.0 \\
\text { (range } \\
15.3 \\
58.7 \text { ) }\end{array}$ & $\begin{array}{l}\text { median } 728 \\
\text { (range 439, } \\
2158)\end{array}$ & 31.8 (4.1) & \\
\hline & $\begin{array}{l}\text { "Fish oil" } \\
\text { (DHA+EPA) } \\
\text { [Omega3 } 4 \text { g/d] (99) }\end{array}$ & 71.7 & $\begin{array}{l}88.9 \\
\text { white, } 2 \\
\text { black, } 8.1 \\
\text { Asian, } \\
7.1 \\
\text { Hispanic, } \\
1 \text { other }\end{array}$ & $\begin{array}{l}52.9 \\
(10.9)\end{array}$ & $\begin{array}{l}129.6 \\
(12.1)\end{array}$ & $\begin{array}{l}80.7 \\
(7.6)\end{array}$ & & $\begin{array}{l}\text { median } 254 \\
\text { (range 119, } \\
564 \text { ) }\end{array}$ & $\begin{array}{l}\text { median } \\
90.3 \\
\text { (range } \\
11.7, \\
223 \text { ) }\end{array}$ & $\begin{array}{l}\text { median } \\
28.7 \\
\text { (range } \\
12.7 . \\
69.3 \text { ) }\end{array}$ & $\begin{array}{l}\text { median } 655 \\
\text { (range 435, } \\
2095)\end{array}$ & $31.0(5.1)$ & \\
\hline \multirow[t]{2}{*}{$\begin{array}{l}\text { NCT01242527 } \\
\text { (Kastelein } 2014 \\
\text { 24528690) }\end{array}$} & $\begin{array}{l}\text { Placebo [olive oil] } \\
\text { (99) }\end{array}$ & 77.8 & $\begin{array}{l}6 \\
\text { Hispanic } \\
\text { or Latino; } \\
94 \text { not } \\
\text { Hispanic } \\
\text { or Latino }\end{array}$ & $\begin{array}{l}50.8 \\
(10.6)\end{array}$ & & & & & & & & & $\begin{array}{l}\text { Yes - } \\
\text { exact } \\
\text { match }\end{array}$ \\
\hline & $\begin{array}{l}\text { "Fish oil" } \\
\text { (DHA+EPA) } \\
\text { [Omega3 } 2 \text { g/d; } \\
\text { olive oil } 2 \text { g/d] (100) }\end{array}$ & 80 & $\begin{array}{l}8 \\
\text { Hispanic } \\
\text { or Latino; } \\
92 \text { not } \\
\text { Hispanic } \\
\text { or Latino }\end{array}$ & $\begin{array}{l}51.1 \\
(9.8)\end{array}$ & & & & & & & & & $\begin{array}{l}\text { Yes - } \\
\text { exact } \\
\text { match }\end{array}$ \\
\hline
\end{tabular}




\begin{tabular}{|c|c|c|c|c|c|c|c|c|c|c|c|c|c|}
\hline $\begin{array}{l}\text { Author, year, } \\
\text { PMID }\end{array}$ & Arm (N) & $\begin{array}{l}\text { Male } \\
\%\end{array}$ & Race \% & $\begin{array}{l}\text { Age } \\
\text { mean } \\
\text { years }\end{array}$ & $\begin{array}{l}\text { SBP } \\
\text { mean } \\
\text { (SD) } \\
\mathrm{mmHg}\end{array}$ & $\begin{array}{l}\mathrm{DBP} \\
\text { mean } \\
\text { (SD) } \\
\mathrm{mmHg}\end{array}$ & $\begin{array}{l}\text { MAP } \\
\text { mean } \\
\text { (SD) } \\
\text { mmHg }\end{array}$ & $\begin{array}{l}\text { Total } \\
\text { Cholesterol } \\
\text { mean (SD) } \\
\text { mg/dL } \\
\text { [mmol/L] }\end{array}$ & $\begin{array}{l}\mathrm{LDL} \\
\text { mean } \\
(\mathrm{SD}) \\
\mathrm{mg} / \mathrm{dL} \\
{[\mathrm{mmol} / \mathrm{L}]}\end{array}$ & $\begin{array}{l}\mathrm{HDL} \\
\text { mean } \\
(\mathrm{SD}) \\
\mathrm{mg} / \mathrm{dL} \\
{[\mathrm{mmol} / \mathrm{L}]}\end{array}$ & $\begin{array}{l}\text { Triglycerides } \\
\text { mean (SD) } \\
\mathrm{mg} / \mathrm{dL} \\
{[\mathrm{mmol} / \mathrm{L}]}\end{array}$ & $\begin{array}{l}\text { BMI mean } \\
\text { (SD) } \\
\mathrm{Kg} / \mathrm{m} 2\end{array}$ & $\begin{array}{l}\text { Do they } \\
\text { match } \\
\text { where } \\
\text { there is } \\
\text { data }\end{array}$ \\
\hline & $\begin{array}{l}\text { "Fish oil" } \\
\text { (DHA+EPA) } \\
\text { [Omega3 } 3 \mathrm{~g} / \mathrm{d} \text {, } \\
\text { olive oil } 1 \mathrm{~g} / \mathrm{d}] \text { (101) }\end{array}$ & 78 & $\begin{array}{l}4 \\
\text { Hispanic } \\
\text { or Latino; } \\
96 \text { not } \\
\text { Hispanic } \\
\text { or Latino } \\
\end{array}$ & $\begin{array}{l}51.2 \\
(8.8)\end{array}$ & & & & & & & & & $\begin{array}{l}\text { Yes - } \\
\text { exact } \\
\text { match }\end{array}$ \\
\hline & $\begin{array}{l}\text { "Fish oil" } \\
\text { (DHA+EPA) } \\
\text { [Omega3 } 4 \text { g/d]) } \\
\text { (99) }\end{array}$ & 71.7 & $\begin{array}{l}7 \\
\text { Hispanic } \\
\text { or Latino; } \\
93 \text { not } \\
\text { Hispanic } \\
\text { or Latino } \\
\end{array}$ & $\begin{array}{l}52.9 \\
(10.9)\end{array}$ & & & & & & & & & $\begin{array}{l}\text { Yes - } \\
\text { exact } \\
\text { match }\end{array}$ \\
\hline \multirow[t]{3}{*}{$\begin{array}{l}\text { Maki, 2013, } \\
23998969\end{array}$} & Placebo (211) & 56.7 & $\begin{array}{l}91.6 \\
\text { white, } 4.7 \\
\text { black, } 1.4 \\
\text { Asian, } \\
2.3 \\
\text { American } \\
\text { Indian or } \\
\text { Alaska } \\
\text { native, } \\
\text { native } \\
\text { Hawaiian, } \\
\text { or Pacific } \\
\text { Islander, } \\
\text { multiple, } \\
\text { other }\end{array}$ & $\begin{array}{l}61.5 \\
(9.6)\end{array}$ & $\begin{array}{l}128.9 \\
(14.3)\end{array}$ & $\begin{array}{l}76.1 \\
(7.7)\end{array}$ & & $174(29.5)$ & $\begin{array}{l}91.7 \\
(27.3)\end{array}$ & $\begin{array}{l}38.3 \\
(9.0)\end{array}$ & $280(70.7)$ & $32.7(5.3)$ & \\
\hline & $\begin{array}{l}\text { All n3 PUFAs } \\
\text { (ALA+DHA+EPA) [2 } \\
\text { g] }(209)\end{array}$ & 57.2 & $\begin{array}{l}96.3 \\
\text { white, } 3.3 \\
\text { black, } 1 \\
\text { other }\end{array}$ & $\begin{array}{l}60.9 \\
(10)\end{array}$ & $\begin{array}{l}128.3 \\
(15)\end{array}$ & $\begin{array}{l}75.7 \\
(8.9)\end{array}$ & & $179(29.1)$ & $\begin{array}{l}92.3 \\
(26.0)\end{array}$ & $\begin{array}{l}38.7 \\
(9.9)\end{array}$ & $284(76.7)$ & $33.3(6.2)$ & \\
\hline & $\begin{array}{l}\text { All n3 PUFAs } \\
\text { (ALA+DHA+EPA) [4 } \\
\text { g] (207) }\end{array}$ & 63.4 & $\begin{array}{l}94.4 \\
\text { white, } 2.3 \\
\text { black, } 1.9 \\
\text { Asian, } \\
1.4 \text { other }\end{array}$ & $\begin{array}{l}60.1 \\
(9.2)\end{array}$ & $\begin{array}{l}129.7 \\
(13.3)\end{array}$ & $\begin{array}{l}77.1 \\
(9.0)\end{array}$ & & $178(29.1)$ & $\begin{array}{l}93.6 \\
(27.6)\end{array}$ & $\begin{array}{l}38.8 \\
(10.9)\end{array}$ & 287 (82.8) & $33.3(6.6)$ & \\
\hline
\end{tabular}




\begin{tabular}{|c|c|c|c|c|c|c|c|c|c|c|c|c|c|}
\hline $\begin{array}{l}\text { Author, year, } \\
\text { PMID }\end{array}$ & Arm (N) & $\begin{array}{l}\text { Male } \\
\%\end{array}$ & Race \% & $\begin{array}{l}\text { Age } \\
\text { mean } \\
\text { years }\end{array}$ & $\begin{array}{l}\text { SBP } \\
\text { mean } \\
(\mathrm{SD}) \\
\mathrm{mmHg}\end{array}$ & $\begin{array}{l}\text { DBP } \\
\text { mean } \\
(\mathrm{SD}) \\
\mathrm{mmHg}\end{array}$ & $\begin{array}{l}\text { MAP } \\
\text { mean } \\
(\mathrm{SD}) \\
\mathrm{mmHg}\end{array}$ & $\begin{array}{l}\text { Total } \\
\text { Cholesterol } \\
\text { mean (SD) } \\
\text { mg/dL } \\
\text { [mmol/L] }\end{array}$ & $\begin{array}{l}\mathrm{LDL} \\
\text { mean } \\
(\mathrm{SD}) \\
\mathrm{mg} / \mathrm{dL} \\
{[\mathrm{mmol} / \mathrm{L}]}\end{array}$ & $\begin{array}{l}\mathrm{HDL} \\
\text { mean } \\
(\mathrm{SD}) \\
\mathrm{mg} / \mathrm{dL} \\
{[\mathrm{mmol} / \mathrm{L}]}\end{array}$ & $\begin{array}{l}\text { Triglycerides } \\
\text { mean (SD) } \\
\mathrm{mg} / \mathrm{dL} \\
{[\mathrm{mmol} / \mathrm{L}]}\end{array}$ & $\begin{array}{l}\text { BMI mean } \\
\text { (SD) } \\
\mathrm{Kg} / \mathrm{m} 2\end{array}$ & $\begin{array}{l}\text { Do they } \\
\text { match } \\
\text { where } \\
\text { there is } \\
\text { data }\end{array}$ \\
\hline \multirow[t]{3}{*}{$\begin{array}{l}\text { NCT01408303 } \\
\text { (Maki, 2013, } \\
\text { 23998969) } \\
\end{array}$} & Placebo (216) & 57 & & $\begin{array}{l}61.5 \\
(9.6)\end{array}$ & & & & & & & & & $\begin{array}{l}\text { Yes - } \\
\text { exact } \\
\text { match }\end{array}$ \\
\hline & $\begin{array}{l}\text { All n3 PUFAs } \\
\text { (ALA+DHA+EPA) [2 } \\
\text { g] (215) }\end{array}$ & 57 & & $\begin{array}{l}60.9 \\
(10)\end{array}$ & & & & & & & & & $\begin{array}{l}\text { Yes - } \\
\text { exact } \\
\text { match }\end{array}$ \\
\hline & $\begin{array}{l}\text { All n3 PUFAs } \\
\text { (ALA+DHA+EPA) [4 } \\
\text { g] (216) }\end{array}$ & 63 & & $\begin{array}{l}60.1 \\
(9.2)\end{array}$ & & & & & & & & & $\begin{array}{l}\text { Yes - } \\
\text { exact } \\
\text { match }\end{array}$ \\
\hline \multirow[t]{4}{*}{$\begin{array}{l}\text { Nodari, 2011, } \\
21844082 \\
\end{array}$} & Placebo (99) & 63.6 & & $69(9)$ & $\begin{array}{l}136 \\
(16)\end{array}$ & $82(9)$ & & & & & & $23.6(5.3)$ & \\
\hline & $\begin{array}{l}\text { All n3 PUFAs } \\
\text { (ALA+DHA+EPA) } \\
(100) \\
\end{array}$ & 70 & & $70(6)$ & $\begin{array}{l}134 \\
(20)\end{array}$ & $82(10)$ & & & & & & $23.8(5.2)$ & \\
\hline & Placebo (66) & 84.9 & & $64(9)$ & $\begin{array}{l}120.5 \\
(12.2)\end{array}$ & $\begin{array}{l}76.2 \\
(5.1)\end{array}$ & & $187(28)$ & & & $154(76)$ & $25.7(2.22)$ & \\
\hline & $\begin{array}{l}\text { "Fish oil" } \\
\text { (DHA+EPA) (67) }\end{array}$ & 95.5 & & $61(11)$ & $\begin{array}{l}119.5 \\
(9.2)\end{array}$ & $\begin{array}{l}76.0 \\
(5.2)\end{array}$ & & $187(26)$ & & & $149(62)$ & $25.9(2.3)$ & $\begin{array}{l}\text { No match } \\
\text { in record } \\
\text { for this } \\
\text { arm }\end{array}$ \\
\hline \multirow[t]{2}{*}{$\begin{array}{l}\text { NCT01198275 } \\
\text { (Nodari, 2011, } \\
\text { 21844082) } \\
\end{array}$} & $\begin{array}{l}\text { Placebo (Olive oil) } \\
\text { (99) }\end{array}$ & 63 & & $69(9)$ & & & & & & & & & $\begin{array}{l}\text { Yes- } \\
\text { exact } \\
\text { match }\end{array}$ \\
\hline & $\begin{array}{l}\text { DHA+EPA (2g) } \\
(100)\end{array}$ & 70 & & $70(6)$ & & & & & & & & & $\begin{array}{l}\text { Yes - } \\
\text { exact } \\
\text { match to } \\
\text { All n-3 } \\
\text { PUFA } \\
\text { arm of } \\
\text { paper }\end{array}$ \\
\hline $\begin{array}{l}\text { Rodriguez- } \\
\text { Leyva, 2013, } \\
24126178\end{array}$ & Placebo (52) & & & $\begin{array}{l}65.3 \\
(9.4)\end{array}$ & $\begin{array}{l}142.4 \\
(17.5)\end{array}$ & $\begin{array}{l}79.0 \\
(15.7)\end{array}$ & & {$[4.5(1.3)]$} & $\begin{array}{l}{[2.6} \\
(1.0)]\end{array}$ & $\begin{array}{l}{[1.2} \\
(0.3)]\end{array}$ & {$[1.7(0.8)]$} & $28.1(4.4)$ & \\
\hline
\end{tabular}




\begin{tabular}{|c|c|c|c|c|c|c|c|c|c|c|c|c|c|}
\hline $\begin{array}{l}\text { Author, year, } \\
\text { PMID }\end{array}$ & Arm (N) & $\begin{array}{l}\text { Male } \\
\%\end{array}$ & Race \% & $\begin{array}{l}\text { Age } \\
\text { mean } \\
\text { years }\end{array}$ & $\begin{array}{l}\text { SBP } \\
\text { mean } \\
(\mathrm{SD}) \\
\mathrm{mmHg}\end{array}$ & $\begin{array}{l}\text { DBP } \\
\text { mean } \\
(\mathrm{SD}) \\
\mathrm{mmHg}\end{array}$ & $\begin{array}{l}\text { MAP } \\
\text { mean } \\
(\mathrm{SD}) \\
\mathrm{mmHg}\end{array}$ & $\begin{array}{l}\text { Total } \\
\text { Cholesterol } \\
\text { mean (SD) } \\
\text { mg/dL } \\
{[\mathrm{mmol} / \mathrm{L}]}\end{array}$ & $\begin{array}{l}\mathrm{LDL} \\
\text { mean } \\
(\mathrm{SD}) \\
\mathrm{mg} / \mathrm{dL} \\
{[\mathrm{mmol} / \mathrm{L}]}\end{array}$ & $\begin{array}{l}\mathrm{HDL} \\
\text { mean } \\
(\mathrm{SD}) \\
\mathrm{mg} / \mathrm{dL} \\
{[\mathrm{mmol} / \mathrm{L}]}\end{array}$ & $\begin{array}{l}\text { Triglycerides } \\
\text { mean (SD) } \\
\mathrm{mg} / \mathrm{dL} \\
{[\mathrm{mmol} / \mathrm{L}]}\end{array}$ & $\begin{array}{l}\text { BMI mean } \\
\text { (SD) } \\
\mathrm{Kg} / \mathrm{m} 2\end{array}$ & $\begin{array}{l}\text { Do they } \\
\text { match } \\
\text { where } \\
\text { there is } \\
\text { data }\end{array}$ \\
\hline & $\begin{array}{l}\text { All n3 PUFAs } \\
\text { (ALA+DHA+EPA) } \\
\text { [flaxseed group] } \\
\text { (58) }\end{array}$ & & & $\begin{array}{l}67.4 \\
(8.06)\end{array}$ & $\begin{array}{l}143.3 \\
(22.2)\end{array}$ & $\begin{array}{l}77.0 \\
(9.5)\end{array}$ & & {$[4.4(1.1)]$} & $\begin{array}{l}{[2.5} \\
(1.0)]\end{array}$ & $\begin{array}{l}{[1.2} \\
(0.3)]\end{array}$ & {$[1.6(0.7)]$} & $27.4(4.4)$ & \\
\hline \multirow[t]{2}{*}{$\begin{array}{l}\text { NCT00781950 } \\
\text { (Rodriguez- } \\
\text { Leyva, 2013, } \\
\text { 24126178) } \\
\end{array}$} & Placebo (52) & 73 & & $\begin{array}{l}65.3 \\
(9.4)\end{array}$ & & & & & & & & & $\begin{array}{l}\text { Yes - } \\
\text { exact } \\
\text { match }\end{array}$ \\
\hline & ALA (flaxseed) (58) & 74 & & $\begin{array}{l}67.4 \\
(8.1)\end{array}$ & & & & & & & & & $\begin{array}{l}\text { Yes - } \\
\text { exact } \\
\text { match }\end{array}$ \\
\hline
\end{tabular}

Table E-6: Adverse effects/events

\begin{tabular}{|c|c|c|c|c|c|c|c|}
\hline $\begin{array}{l}\text { Study Year PMID } \\
\text { Region } \\
\text { (Population) }\end{array}$ & $\begin{array}{l}\text { Flup } \\
\text { Time }\end{array}$ & n-3 FA (N) & Dose & AE n-3 FA & $\begin{array}{l}\text { Control } \\
\text { (N) }\end{array}$ & AE Control & Match \\
\hline $\begin{array}{l}\text { Maki } 2013 \\
23998969 \text { US }\end{array}$ & $\begin{array}{l}1.5 \\
\text { mo }\end{array}$ & $\begin{array}{l}\text { EPA+DHA } \\
(216)\end{array}$ & $4 \mathrm{~g} / \mathrm{d}$ & $\begin{array}{l}\text { Total: } 41.7 \% \\
\text { Serious AEs: } 0.5 \% \text { (coronary artery disease) } \\
\text { AEs related to treatment: } 20.4 \% \text { (nausea, } \\
\text { diarrhea, or epigastric discomfort) } \\
\text { AEs leading to discontinuation: } 3.2 \%\end{array}$ & $\begin{array}{l}\text { Placebo } \\
\text { (216) }\end{array}$ & $\begin{array}{l}\text { Total: } 27.9 \% \\
\text { Serious AEs: } 1.4 \% \text { (intestinal obstruction, } \\
\text { bronchitis, and hyperglycemia) } \\
\text { AEs related to treatment: } 6.0 \% \text { (nausea, } \\
\text { diarrhea, or epigastric discomfort) } \\
\text { AEs leading to discontinuation: } 0.9 \%\end{array}$ & \\
\hline $\begin{array}{l}\text { NCT01408303 } \\
\text { (Maki, } 2013 \\
\text { 23998969) }\end{array}$ & & $\begin{array}{l}\text { EPA+DHA } \\
(216)\end{array}$ & $4 \mathrm{~g} / \mathrm{d}$ & $\begin{array}{l}\text { Serious AEs: } 1 \text { coronary artery disease }(0.5 \%) \\
\text { AEs related to treatment: } 36 \text { diarrhea, } 13 \\
\text { nausea }\end{array}$ & $\begin{array}{l}\text { Placebo } \\
(215)\end{array}$ & $\begin{array}{l}\text { Serious AEs: } 1 \text { intestinal obstruction, } 1 \\
\text { bronchitis, and } 1 \text { hyperglycemia (1.4\%) } \\
\text { AEs related to treatment: } 5 \text { diarrhea; } 3 \\
\text { nausea }\end{array}$ & $\begin{array}{l}\text { Serious AEs match } \\
\text { paper; other AEs } \\
\text { match paper }\end{array}$ \\
\hline $\begin{array}{l}\text { Maki } 2013 \\
23998969 \text { US }\end{array}$ & & $\begin{array}{l}\text { EPA+DHA } \\
(215)\end{array}$ & $2 \mathrm{~g} / \mathrm{d}$ & $\begin{array}{l}\text { Total: } 33.0 \% \\
\text { Serious AEs: } 1.4 \% \text { (diverticular perforation, } \\
\text { musculoskeletal chest pain, and osteoarthritis) } \\
\text { AEs related to treatment: } 9.8 \% \text { (nausea, } \\
\text { diarrhea, or epigastric discomfort) } \\
\text { AEs leading to discontinuation: } 1.4 \%\end{array}$ & & & \\
\hline $\begin{array}{l}\text { NCT01408303 } \\
\text { (Maki, } 2013 \\
\text { 23998969) }\end{array}$ & & $\begin{array}{l}\text { EPA+DHA } \\
(215)\end{array}$ & $2 \mathrm{~g} / \mathrm{d}$ & $\begin{array}{l}\text { Serious AEs: } 1 \text { diverticular perforation, } 1 \\
\text { musculoskeletal chest pain, and } 1 \text { osteoarthritis } \\
(1.4 \%) \\
\text { AEs related to treatment: } 13 \text { diarrhea; } 6 \\
\text { nausea }\end{array}$ & & & $\begin{array}{l}\text { Serious AEs match } \\
\text { paper; other AEs } \\
\text { match paper }\end{array}$ \\
\hline
\end{tabular}




\begin{tabular}{|c|c|c|c|c|c|c|c|}
\hline $\begin{array}{l}\text { Nodari } 2011 \\
21844082 \text { Italy } \\
\text { (CVD) }\end{array}$ & $1 \mathrm{y}$ & $\begin{array}{l}\text { EPA+DHA } \\
(94)\end{array}$ & $\begin{array}{l}0.850-0.882 \\
\mathrm{~g} / \mathrm{d}\end{array}$ & Total: $2.1 \%$ & $\begin{array}{l}\text { Placebo } \\
(94)\end{array}$ & Total: 3.2\% & \\
\hline $\begin{array}{l}\text { NCT01198275 } \\
\text { (Nodari, } 2011 \\
21844082 \text { ) }\end{array}$ & & $\begin{array}{l}\text { EPA+DHA } \\
(100)\end{array}$ & $\begin{array}{l}0.850-0.882 \\
\mathrm{~g} / \mathrm{d}\end{array}$ & $\begin{array}{l}\text { Record reported no serious or other adverse } \\
\text { events in the population. No details as to what } \\
\text { was specified as an adverse event. }\end{array}$ & $\begin{array}{l}\text { Placebo } \\
\text { (99) }\end{array}$ & $\begin{array}{l}\text { Record reported no serious or other } \\
\text { adverse events in the population. No } \\
\text { details as to what was specified as an } \\
\text { adverse event. }\end{array}$ & $\begin{array}{l}\text { Matches paper } \\
\text { (withdrawal } \\
\text { information not } \\
\text { given in registry } \\
\text { record) }\end{array}$ \\
\hline $\begin{array}{l}\text { Kastelein } 2014 \\
24528690 \text { Europe } \\
\text { (Dyslipidemia) }\end{array}$ & $12 \mathrm{wk}$ & $\begin{array}{l}\text { EPA+DHA } \\
(99)(4 \mathrm{~g} / \mathrm{d})\end{array}$ & $3.0 \mathrm{~g} / \mathrm{d}$ & $\begin{array}{l}\text { Total: } 44.4 \% \\
\text { AEs related to treatment: } 25.3 \% \\
\text { Severe AEsłł: } 1.0 \% \\
\text { Diarrhea: } 10.1 \% \\
\text { Nausea: } 5.1 \% \\
\text { Vomiting: } 0 \% \\
\text { Abdominal pain: } 1.0 \%\end{array}$ & $\begin{array}{l}\text { Placebo } \\
\text { (99) }\end{array}$ & $\begin{array}{l}\text { Total: } 26.3 \% \\
\text { AEs related to treatment: } 3.0 \% \\
\text { Severe AEs§§: } 5.1 \% \\
\text { Diarrhea: } 2.0 \% \\
\text { Nausea: } 1.0 \% \\
\text { Vomiting: } 1.0 \% \\
\text { Abdominal pain: } 1.0 \%\end{array}$ & \\
\hline $\begin{array}{l}\text { NCT01242527 } \\
\text { (Kastelein } 2014 \\
24528690\end{array}$ & & $\begin{array}{l}\text { EPA+DHA } \\
(100)\end{array}$ & $4 \mathrm{~g} / \mathrm{d}$ & $\begin{array}{l}10 \text { diarrhea } \\
5 \text { nausea } \\
1 \text { nasopharyngitis }\end{array}$ & $\begin{array}{l}\text { Placebo } \\
\text { (99) }\end{array}$ & $\begin{array}{l}1 \text { abdominal pain } \\
2 \text { diarrhea } \\
1 \text { nausea } \\
1 \text { nasopharyngitis }\end{array}$ & $\begin{array}{l}\text { Fewer AEs reported } \\
\text { in record than in } \\
\text { paper, but the ones } \\
\text { that were reported } \\
\text { match }\end{array}$ \\
\hline $\begin{array}{l}\text { Kastelein } 2014 \\
24528690 \text { Europe }\end{array}$ & & $\begin{array}{l}\text { EPA+DHA } \\
(101)(3 \mathrm{~g} / \mathrm{d})\end{array}$ & $\begin{array}{l}\text { EPA: } 2.25 \\
\mathrm{~g} / \mathrm{d}\end{array}$ & $\begin{array}{l}\text { Total: } 42.6 \% \\
\text { AEs related to treatment: } 16.8 \% \\
\text { Severe AEs: } 3.0 \% \\
\text { Diarrhea: } 5.9 \% \\
\text { Nausea: } 8.9 \% \\
\text { Vomiting: } 4.0 \% \\
\text { Abdominal pain: } 1.0 \%\end{array}$ & & & \\
\hline $\begin{array}{l}\text { NCT01242527 } \\
\text { (Kastelein } 2014 \\
24528690\end{array}$ & & $\begin{array}{l}\text { EPA+DHA } \\
(101)\end{array}$ & $3 \mathrm{~g} / \mathrm{d}$ & $\begin{array}{l}6 \text { diarrhea } \\
9 \text { nausea } \\
3 \text { nasopharyngitis }\end{array}$ & & & $\begin{array}{l}\text { Fewer AEs reported } \\
\text { in record than in } \\
\text { paper, but the ones } \\
\text { that were reported } \\
\text { match }\end{array}$ \\
\hline $\begin{array}{l}\text { Kastelein } 2014 \\
24528690 \text { Europe }\end{array}$ & & $\begin{array}{l}\text { EPA+DHA } \\
(100)(2 \mathrm{~g} / \mathrm{d})\end{array}$ & $\begin{array}{l}\text { EPA: } 1.50 \\
\mathrm{~g} / \mathrm{d}\end{array}$ & $\begin{array}{l}\text { Total: } 40.0 \% \\
\text { AEs related to treatment: } 18.0 \% \\
\text { Severe AEs: } 2.0 \% \\
\text { Diarrhea: } 10.0 \% \\
\text { Nausea: } 6.0 \% \\
\text { Vomiting: } 2.0 \% \\
\text { Abdominal pain: } 4.0 \%\end{array}$ & & & \\
\hline $\begin{array}{l}\text { NCT01242527 } \\
\text { (Kastelein } 2014 \\
\text { 24528690) }\end{array}$ & & $\begin{array}{l}\text { EPA+DHA } \\
(99)\end{array}$ & $2 \mathrm{~g} / \mathrm{d}$ & $\begin{array}{l}10 \text { diarrhea } \\
6 \text { nausea } \\
7 \text { nasopharyngitis }\end{array}$ & & & $\begin{array}{l}\text { Fewer AEs reported } \\
\text { in record than in } \\
\text { paper, but the ones } \\
\text { that were reported } \\
\text { match }\end{array}$ \\
\hline
\end{tabular}




\begin{tabular}{|l|l|l|l|l|l|l|}
\hline $\begin{array}{l}\text { Rodriguez-Leyeza, } \\
2013 \text { 24126178 }\end{array}$ & 1 y & ALA (59) & $5.9 \mathrm{~g} / \mathrm{d}$ & No AEs reported & $\begin{array}{l}\text { Placebo } \\
\text { (52) }\end{array}$ & No AEs reported \\
\hline $\begin{array}{l}\text { NCT00781950 } \\
\text { (Rodriguez-Leyeza, } \\
2013 \text { 24126178) }\end{array}$ & & ALA (59) & $5.9 \mathrm{~g} / \mathrm{d}$ & 3 nausea & & O nausea \\
& & & & $\begin{array}{l}\text { Nausea was an AE } \\
\text { in the record, but } \\
\text { not mentioned in } \\
\text { the papers }\end{array}$ \\
\hline
\end{tabular}

Table E-7: Risk of Bias, Comparative Studies

\begin{tabular}{|c|c|c|c|c|c|c|c|c|c|c|c|}
\hline $\begin{array}{l}\text { Author, Year } \\
\text { PMIDS* }\end{array}$ & $\begin{array}{l}\text { Randomization: } \\
\text { allocation } \\
\text { sequence } \\
\text { adequately } \\
\text { generated }\end{array}$ & $\begin{array}{l}\text { Allocation } \\
\text { adequately } \\
\text { concealed }\end{array}$ & $\begin{array}{l}\text { Participants } \\
\text { adequately } \\
\text { blinded }\end{array}$ & $\begin{array}{l}\text { Outcome } \\
\text { assessors } \\
\text { adequately } \\
\text { blinded }\end{array}$ & $\begin{array}{l}\text { Attrition } \\
\text { bias: } \\
\text { Incomplete } \\
\text { outcome } \\
\text { data }\end{array}$ & $\begin{array}{l}\text { Selective } \\
\text { outcome } \\
\text { reporting } \\
\text { bias } \\
\text { (Yes/No) }\end{array}$ & $\begin{array}{l}\text { Intention- } \\
\text { to-treat } \\
\text { analysis? } \\
\text { (Yes/No) }\end{array}$ & $\begin{array}{l}\text { Group } \\
\text { similarity at } \\
\text { baseline } \\
\text { (general) }\end{array}$ & $\begin{array}{l}\text { Group } \\
\text { similarity } \\
\text { at } \\
\text { baseline } \\
\text { (Omega- } \\
\text { 3) }\end{array}$ & $\begin{array}{l}\text { Similar } \\
\text { compliance } \\
\text { across } \\
\text { groups }\end{array}$ & $\begin{array}{l}\text { Additional } \\
\text { bias }\end{array}$ \\
\hline $\begin{array}{l}\text { Baxheinrich, 2012, } \\
22894911\end{array}$ & Unclear & Unclear & High & Low & Low & No & No & Low & Unclear & High & \\
\hline $\begin{array}{l}\text { DRKS00006232 } \\
\text { (Baxheinrich, } \\
2012,22894911 \text { ) }\end{array}$ & Unclear & Unclear & Low & Unclear & Unclear & Unclear & Unclear & Unclear & Unclear & Unclear & \\
\hline $\begin{array}{l}\text { Bosch, 2012, } \\
22686415\end{array}$ & Unclear & Low & Low & Low & Low & No & No & Low & Low & Unclear & \\
\hline $\begin{array}{l}\text { NCT00069784 } \\
\text { (Bosch, 2012, } \\
22686415)\end{array}$ & Unclear & Unclear & Low & Unclear & $\begin{array}{l}\text { Unclear } \\
\text { (numbers } \\
\text { lost to } \\
\text { followup } \\
\text { given for } \\
\text { the wrong } \\
\text { arms) }\end{array}$ & Unclear & Yes & $\begin{array}{l}\text { Unclear } \\
\text { (baselines } \\
\text { given for } \\
\text { wrong arms) }\end{array}$ & $\begin{array}{l}\text { Unclear } \\
\text { (baselines } \\
\text { given for } \\
\text { wrong } \\
\text { arms) }\end{array}$ & $\begin{array}{l}\text { Unclear } \\
\text { (baselines } \\
\text { given for } \\
\text { wrong arms) }\end{array}$ & \\
\hline $\begin{array}{l}\text { Brinton, 2013, } \\
22819432 \\
23835245 \\
\end{array}$ & Unclear & Low & Low & Low & Low & No & Yes & Low & Unclear & Unclear & \\
\hline $\begin{array}{l}\text { NCT01047501 } \\
\text { (Brinton, 2013, } \\
\text { 23835245) }\end{array}$ & Unclear & Low & Low & Low & Unclear & No & Yes & Unclear & Unclear & Unclear & No \\
\hline $\begin{array}{l}\text { Brouwer, 2006, } \\
16772624\end{array}$ & Low & Low & Low & Low & Low & No & Yes & Low & Low & Low & \\
\hline $\begin{array}{l}\text { NCT00110838 } \\
\text { (Brouwer, 2006, } \\
\text { 16772624) }\end{array}$ & Unclear & Low & Low & Low & Unclear & No & Unclear & Low & Unclear & Unclear & No \\
\hline $\begin{array}{l}\text { Damsgaard, 2008, } \\
18492834\end{array}$ & Low & Low & Low & Low & Low & No & Yes & Low & Low & Low & \\
\hline
\end{tabular}




\begin{tabular}{|c|c|c|c|c|c|c|c|c|c|c|c|}
\hline $\begin{array}{l}\text { Author, Year } \\
\text { PMIDS* }\end{array}$ & $\begin{array}{l}\text { Randomization: } \\
\text { allocation } \\
\text { sequence } \\
\text { adequately } \\
\text { generated }\end{array}$ & $\begin{array}{l}\text { Allocation } \\
\text { adequately } \\
\text { concealed }\end{array}$ & $\begin{array}{l}\text { Participants } \\
\text { adequately } \\
\text { blinded }\end{array}$ & $\begin{array}{l}\text { Outcome } \\
\text { assessors } \\
\text { adequately } \\
\text { blinded }\end{array}$ & $\begin{array}{l}\text { Attrition } \\
\text { bias: } \\
\text { Incomplete } \\
\text { outcome } \\
\text { data }\end{array}$ & $\begin{array}{l}\text { Selective } \\
\text { outcome } \\
\text { reporting } \\
\text { bias } \\
\text { (Yes/No) }\end{array}$ & $\begin{array}{l}\text { Intention- } \\
\text { to-treat } \\
\text { analysis? } \\
\text { (Yes/No) }\end{array}$ & $\begin{array}{l}\text { Group } \\
\text { similarity at } \\
\text { baseline } \\
\text { (general) }\end{array}$ & $\begin{array}{l}\text { Group } \\
\text { similarity } \\
\text { at } \\
\text { baseline } \\
\text { (Omega- } \\
\text { 3) }\end{array}$ & $\begin{array}{l}\text { Similar } \\
\text { compliance } \\
\text { across } \\
\text { groups }\end{array}$ & $\begin{array}{l}\text { Additional } \\
\text { bias }\end{array}$ \\
\hline $\begin{array}{l}\text { NCT00266292 } \\
\text { (Damsgaard, } \\
\text { 2008, 18492834) }\end{array}$ & Unclear & Low & Low & Low & Unclear & No & Yes & Low & Unclear & Unclear & No \\
\hline $\begin{array}{l}\text { Galan, 2010, } \\
18544171 \\
21115589 \\
21801476 \\
22365647\end{array}$ & Low & Low & Low & Unclear & Low & No & Yes & Low & Low & Low & \\
\hline $\begin{array}{l}\text { ISRCTN41926726 } \\
\text { (Galan, 2010, } 1 \\
\text { 21115589) }\end{array}$ & Unclear & Unclear & Low & Unclear & Unclear & Unclear & Unclear & Unclear & Unclear & Unclear & \\
\hline $\begin{array}{l}\text { Holman, 2009, } \\
19002433 \\
21036355\end{array}$ & Low & Low & Low & Low & Low & Yes & No & Low & Low & Low & \\
\hline $\begin{array}{l}\text { NCT00141232 } \\
\text { and } \\
\text { ISRCTN76737502 } \\
\text { (Holman, 2009, } \\
\text { 19002433) }\end{array}$ & Unclear & Unclear & Low & Unclear & Unclear & Unclear & Unclear & Unclear & Unclear & Unclear & \\
\hline $\begin{array}{l}\text { Jones, 2014, } \\
24829493\end{array}$ & Low & Low & Low & Low & High & No & Unclear & Low & Low & Low & \\
\hline $\begin{array}{l}\text { NCT01351012 } \\
\text { (Jones, 2014, } \\
\text { 24829493) }\end{array}$ & Unclear & Low & Low & Low & Unclear & No & Yes & Unclear & Unclear & Unclear & No \\
\hline $\begin{array}{l}\text { Kastelein, 2014, } \\
24528690\end{array}$ & Unclear & Unclear & Low & Unclear & Low & No & Yes & Low & Low & High & \\
\hline $\begin{array}{l}\text { NCT01242527 } \\
\text { (Kastelein, 2014, } \\
\text { 24528690) }\end{array}$ & Unclear & Unclear & Low & Low & Low & Unclear & Yes & $\begin{array}{l}\text { Unclear (only } \\
\text { demographic } \\
\text { information } \\
\text { given) }\end{array}$ & Unclear & Unclear & \\
\hline $\begin{array}{l}\text { Kromhout, 2010, } \\
20362710 \\
20929341 \\
22110169 \\
22301766 \\
\end{array}$ & Low & Low & Low & Low & Low & No & Yes & Low & Low & High & \\
\hline $\begin{array}{l}\text { NCT00127452 } \\
\text { (Kromhout, 2010, } \\
\text { 20929341) }\end{array}$ & Unclear & Low & Low & Low & Unclear & No & Yes & Unclear & Unclear & Unclear & No \\
\hline
\end{tabular}




\begin{tabular}{|c|c|c|c|c|c|c|c|c|c|c|c|}
\hline $\begin{array}{l}\text { Author, Year } \\
\text { PMIDS* }\end{array}$ & $\begin{array}{l}\text { Randomization: } \\
\text { allocation } \\
\text { sequence } \\
\text { adequately } \\
\text { generated }\end{array}$ & $\begin{array}{l}\text { Allocation } \\
\text { adequately } \\
\text { concealed }\end{array}$ & $\begin{array}{l}\text { Participants } \\
\text { adequately } \\
\text { blinded }\end{array}$ & $\begin{array}{l}\text { Outcome } \\
\text { assessors } \\
\text { adequately } \\
\text { blinded }\end{array}$ & $\begin{array}{l}\text { Attrition } \\
\text { bias: } \\
\text { Incomplete } \\
\text { outcome } \\
\text { data }\end{array}$ & $\begin{array}{l}\text { Selective } \\
\text { outcome } \\
\text { reporting } \\
\text { bias } \\
\text { (Yes/No) }\end{array}$ & $\begin{array}{l}\text { Intention- } \\
\text { to-treat } \\
\text { analysis? } \\
\text { (Yes/No) }\end{array}$ & $\begin{array}{l}\text { Group } \\
\text { similarity at } \\
\text { baseline } \\
\text { (general) }\end{array}$ & $\begin{array}{l}\text { Group } \\
\text { similarity } \\
\text { at } \\
\text { baseline } \\
\text { (Omega- } \\
\text { 3) }\end{array}$ & $\begin{array}{l}\text { Similar } \\
\text { compliance } \\
\text { across } \\
\text { groups }\end{array}$ & $\begin{array}{l}\text { Additiona } \\
\text { bias }\end{array}$ \\
\hline $\begin{array}{l}\text { Kuhnt, } \\
2014,24553695\end{array}$ & Low & Low & LoW & Low & Low & No & No & Low & Low & Unclear & \\
\hline $\begin{array}{l}\text { NCT01856179 } \\
\text { (Kuhnt, } \\
2014,24553695)\end{array}$ & Low & Unclear & Low & Low & Unclear & Unclear & Unclear & Unclear & Unclear & Unclear & \\
\hline $\begin{array}{l}\text { Leaf, 2005, } \\
16267249\end{array}$ & Low & Unclear & Low & Low & Low & No & Yes & Low & Low & Low & \\
\hline $\begin{array}{l}\text { NCT00004559 } \\
\text { (Leaf, 2005, } \\
\text { 16267249) }\end{array}$ & Unclear & Low & Low & Low & Unclear & No & Yes & Unclear & Unclear & Unclear & No \\
\hline $\begin{array}{l}\text { Macchia, 2013, } \\
23265344\end{array}$ & Unclear & Low & Low & Low & Unclear & No & No & Low & Unclear & Unclear & \\
\hline $\begin{array}{l}\text { NCT00597220 } \\
\text { (Macchia, 2013, } \\
\text { 23265344) }\end{array}$ & Low & Unclear & Low & Low & Unclear & Unclear & Unclear & Unclear & Unclear & Unclear & \\
\hline $\begin{array}{l}\text { Maki, } 2010 \text {, } \\
17825687 \\
20451686\end{array}$ & Low & Low & Low & Low & Low & No & Yes & High & Unclear & Low & \\
\hline $\begin{array}{l}\text { NCT00246701 } \\
\text { (Maki, 2010, } \\
\text { 20451686) }\end{array}$ & Low & Unclear & Low & Low & Unclear & Unclear & Unclear & Unclear & Unclear & Unclear & \\
\hline $\begin{array}{l}\text { Maki, 2013, } \\
23998969\end{array}$ & Unclear & Unclear & Low & Low & High & No & Yes & Low & Low & Low & \\
\hline $\begin{array}{l}\text { NCT01408303 } \\
\text { (Maki, 2013, } \\
\text { 23998969) }\end{array}$ & Unclear & Unclear & Low & Unclear & Low & No & Yes & $\begin{array}{l}\text { Unclear } \\
\text { (only age } \\
\text { and gender } \\
\text { baselines } \\
\text { given) }\end{array}$ & Unclear & Low & \\
\hline $\begin{array}{l}\text { Nodari, } 2011 \text {, } \\
21844082\end{array}$ & Low & Low & Low & Low & Unclear & No & No & Low & Unclear & Unclear & \\
\hline $\begin{array}{l}\text { NCT01198275 } \\
\text { (Nodari, 2011, } \\
21844082 \text { ) }\end{array}$ & Unclear & Unclear & Low & Unclear & Low & Unclear & Unclear & Unclear & Unclear & Unclear & \\
\hline $\begin{array}{l}\text { Raitt, 2005, } \\
15956633\end{array}$ & Unclear & Low & Low & Low & Low & No & No & Low & Unclear & Unclear & \\
\hline $\begin{array}{l}\text { NCT00004558 } \\
\text { (Raitt, 2005, } \\
\text { 15956633) }\end{array}$ & Unclear & Unclear & Low & Unclear & Unclear & Unclear & Unclear & Unclear & Unclear & Unclear & \\
\hline
\end{tabular}




\begin{tabular}{|c|c|c|c|c|c|c|c|c|c|c|c|}
\hline $\begin{array}{l}\text { Author, Year } \\
\text { PMIDS* }\end{array}$ & $\begin{array}{l}\text { Randomization: } \\
\text { allocation } \\
\text { sequence } \\
\text { adequately } \\
\text { generated }\end{array}$ & $\begin{array}{l}\text { Allocation } \\
\text { adequately } \\
\text { concealed }\end{array}$ & $\begin{array}{l}\text { Participants } \\
\text { adequately } \\
\text { blinded }\end{array}$ & $\begin{array}{l}\text { Outcome } \\
\text { assessors } \\
\text { adequately } \\
\text { blinded }\end{array}$ & $\begin{array}{l}\text { Attrition } \\
\text { bias: } \\
\text { Incomplete } \\
\text { outcome } \\
\text { data }\end{array}$ & $\begin{array}{l}\text { Selective } \\
\text { outcome } \\
\text { reporting } \\
\text { bias } \\
\text { (Yes/No) }\end{array}$ & $\begin{array}{l}\text { Intention- } \\
\text { to-treat } \\
\text { analysis? } \\
\text { (Yes/No) }\end{array}$ & $\begin{array}{l}\text { Group } \\
\text { similarity at } \\
\text { baseline } \\
\text { (general) }\end{array}$ & $\begin{array}{l}\text { Group } \\
\text { similarity } \\
\text { at } \\
\text { baseline } \\
\text { (Omega- } \\
\text { 3) }\end{array}$ & $\begin{array}{l}\text { Similar } \\
\text { compliance } \\
\text { across } \\
\text { groups }\end{array}$ & $\begin{array}{l}\text { Additional } \\
\text { bias }\end{array}$ \\
\hline $\begin{array}{l}\text { Ras, 2015, } \\
25122648\end{array}$ & Low & Low & Low & Low & Low & Yes & Yes & Low & Unclear & Low & \\
\hline $\begin{array}{l}\text { NCT01313988 } \\
\text { (Ras, 2015, } \\
\text { 25122648) }\end{array}$ & Unclear & Low & Low & Low & Unclear & No & Yes & Unclear & Unclear & Unclear & No \\
\hline $\begin{array}{l}\text { Rauch, 2010, } \\
21060071\end{array}$ & Low & Low & Low & Low & Low & No & Yes & Low & Unclear & Low & $\begin{array}{l}\begin{array}{l}\text { Unclear } \\
\text { (High }\end{array} \\
\text { underlying } \\
\text { levels of fish } \\
\text { consumption } \\
\text { during the } \\
\text { study could } \\
\text { have } \\
\text { influenced } \\
\text { the clinical } \\
\text { event rate } \\
\text { during } \\
\text { followup.) }\end{array}$ \\
\hline $\begin{array}{l}\text { NCT00251134 } \\
\text { (Rauch, 2010, } \\
\text { 21060071) }\end{array}$ & Low & Unclear & Low & Low & Unclear & Unclear & Unclear & Unclear & Unclear & Unclear & \\
\hline $\begin{array}{l}\text { Rodriguez-Leyva, } \\
2013,24126178 \\
25694068\end{array}$ & Low & Low & High & Low & Low & No & Yes & Low & Low & Low & \\
\hline $\begin{array}{l}\text { NCT00781950 } \\
\text { (Rodriguez-Leyva, } \\
2013,24126178 \text { ) }\end{array}$ & Unclear & Unclear & Low & Unclear & 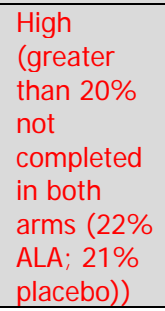 & Unclear & Unclear & $\begin{array}{l}\text { Unclear } \\
\text { (only } \\
\text { demographic } \\
\text { baselines } \\
\text { given) }\end{array}$ & Unclear & $\begin{array}{l}\text { Unclear (no } \\
\text { compliance } \\
\text { data given) }\end{array}$ & \\
\hline $\begin{array}{l}\text { Roncaglioni, 2013, } \\
23656645\end{array}$ & Low & Low & Low & Low & Low & No & Yes & Low & Low & Low & \\
\hline $\begin{array}{l}\text { NCT00317707 } \\
\text { (Roncaglioni, } \\
\text { 2013, 23656645) }\end{array}$ & Low & High & Low & Low & Unclear & Unclear & Unclear & Unclear & Unclear & Unclear & \\
\hline
\end{tabular}




\begin{tabular}{|c|c|c|c|c|c|c|c|c|c|c|c|}
\hline $\begin{array}{l}\text { Author, Year } \\
\text { PMIDS* }\end{array}$ & $\begin{array}{l}\text { Randomization: } \\
\text { allocation } \\
\text { sequence } \\
\text { adequately } \\
\text { generated }\end{array}$ & $\begin{array}{l}\text { Allocation } \\
\text { adequately } \\
\text { concealed }\end{array}$ & $\begin{array}{l}\text { Participants } \\
\text { adequately } \\
\text { blinded }\end{array}$ & $\begin{array}{l}\text { Outcome } \\
\text { assessors } \\
\text { adequately } \\
\text { blinded }\end{array}$ & $\begin{array}{l}\text { Attrition } \\
\text { bias: } \\
\text { Incomplete } \\
\text { outcome } \\
\text { data }\end{array}$ & $\begin{array}{l}\text { Selective } \\
\text { outcome } \\
\text { reporting } \\
\text { bias } \\
\text { (Yes/No) }\end{array}$ & $\begin{array}{l}\text { Intention- } \\
\text { to-treat } \\
\text { analysis? } \\
\text { (Yes/No) }\end{array}$ & $\begin{array}{l}\text { Group } \\
\text { similarity at } \\
\text { baseline } \\
\text { (general) }\end{array}$ & $\begin{array}{l}\text { Group } \\
\text { similarity } \\
\text { at } \\
\text { baseline } \\
\text { (Omega- } \\
\text { 3) }\end{array}$ & $\begin{array}{l}\text { Similar } \\
\text { compliance } \\
\text { across } \\
\text { groups }\end{array}$ & $\begin{array}{l}\text { Additional } \\
\text { bias }\end{array}$ \\
\hline $\begin{array}{l}\text { Sanders, 2011, } \\
21865334\end{array}$ & Low & Low & Low & Low & Low & No & No & Low & Low & Low & \\
\hline $\begin{array}{l}\text { ISRCTN66664610 } \\
\text { (Sanders, 2011, } \\
\text { 21865334) }\end{array}$ & Unclear & Unclear & Low & Unclear & Unclear & Unclear & Unclear & Unclear & Unclear & Unclear & \\
\hline $\begin{array}{l}\text { Tavazzi, 2008, } \\
18757090 \\
19589110 \\
21315217 \\
23351824 \\
23839902\end{array}$ & Low & Low & Low & Low & Low & Yes & Yes & Low & Low & Low & \\
\hline $\begin{array}{l}\text { NCT00336336 } \\
\text { (Tavazzi, 2008, } \\
\text { 18757090) }\end{array}$ & Unclear & Low & Low & Low & Unclear & No & Yes & Unclear & Unclear & Unclear & No \\
\hline $\begin{array}{l}\text { Vazquez, 2014, } \\
24462043\end{array}$ & Low & Low & Low & Low & Low & No & Yes & Low & Unclear & Low & \\
\hline $\begin{array}{l}\text { NCT01758601 } \\
\text { (Vazquez, 2014, } \\
\text { 24462043) }\end{array}$ & Unclear & Low & Low & Low & Unclear & No & Yes & Unclear & Unclear & Unclear & No \\
\hline $\begin{array}{l}\text { Yokoyama, 2007, } \\
17398308 \\
18451347 \\
18667204 \\
19423946 \\
20484828 \\
22186099 \\
22653220\end{array}$ & Low & Low & High & Low & Low & No & Yes & Low & Unclear & Unclear & \\
\hline $\begin{array}{l}\text { NCT00231738 } \\
\text { (Yokoyama, 2007, } \\
\text { 17398308) }\end{array}$ & Unclear & High & High & High & Unclear & No & Yes & Unclear & Unclear & Unclear & No \\
\hline
\end{tabular}

* Author, year of primary study. PMIDs of all included articles. 
Table E-8: Risk of Bias, Observational Studies

\begin{tabular}{|c|c|c|c|c|c|c|}
\hline $\begin{array}{l}\text { Study } \\
\text { PMIDs }\end{array}$ & $\begin{array}{l}\text { Selection bias } \\
\text { (outcome of interest } \\
\text { not present at } \\
\text { baseline) }\end{array}$ & $\begin{array}{l}\text { Comparabilityl } \\
\text { Adjustment } \\
\text { (adjusted for } \\
\text { confounders or } \\
\text { other factors) }\end{array}$ & $\begin{array}{l}\text { Outcome assessors } \\
\text { adequately blinded }\end{array}$ & $\begin{array}{l}\text { Incomplete outcome } \\
\text { data (attrition bias) }\end{array}$ & $\begin{array}{l}\text { Dietary assessment } \\
\text { instrument } \\
\text { described (studies } \\
\text { with FFQ)? }\end{array}$ & $\begin{array}{l}\text { Nutrient exposures } \\
\text { adequately reported }\end{array}$ \\
\hline $\begin{array}{l}\text { Cardiovascular } \\
\text { Health Study } \\
21810709 \\
22282329 \\
22743310 \\
23525429 \\
23546563 \\
25159901\end{array}$ & Low & $\begin{array}{l}\text { Yes (Diet and CVD } \\
\text { risk factors) }\end{array}$ & Low & Low & $\begin{array}{l}\text { Not Applicable } \\
\text { (biomarker) }\end{array}$ & Yes \\
\hline $\begin{array}{l}\text { NCT00005133 } \\
\text { (Cardiovascular } \\
\text { Health Study) }\end{array}$ & Low & Unclear & Unclear & Unclear & Unclear & Unclear \\
\hline
\end{tabular}


